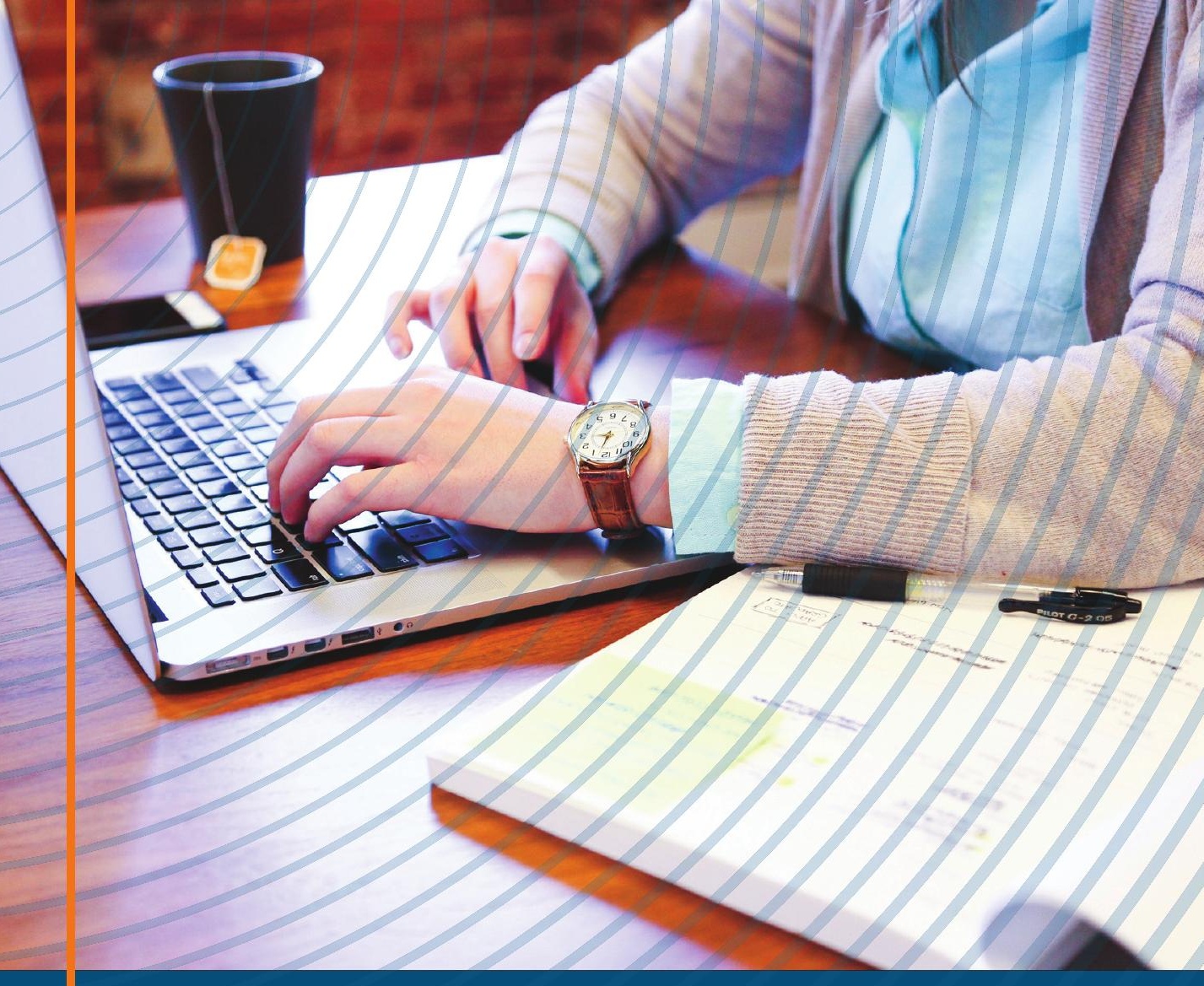

Koronaizziv

visokega šolstva

Viktorija Florjančič 
Znanstvene monografije

Fakultete za management

\section{Glavni urednik}

Matjaž Novak

Uredniški odbor

Ana Arzenšek

Štefan Bojnec

Dubravka Celinšek

Armand Faganel

Viktorija Florjančič

Borut Kodrič

Suzana Laporšek

Mirko Markič

Franko Milost

Matjaž Nahtigal

Mitja Ruzzier

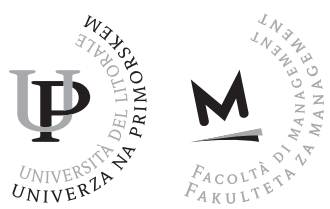




\title{
Koronaizziv visokega šolstva
}

Od teorije k praksi

\author{
Viktorija Florjančič
}

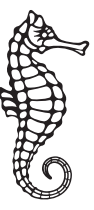


Koronaizziv visokega šolstva: od teorije $k$ praksi

Viktorija Florjančič

Recenzenta $\cdot$ Janez Bešter in Valerij Dermol

Lektoriranje · Davorin Dukič

Oblikovanje in tehnična ureditev · Alen Ježovnik

Izdala in založila $\cdot$ Založba Univerze na Primorskem

Titov trg 4, 60oo Koper

www.hippocampus.si

Glavni urednik · Jonatan Vinkler

Vodja založbe · Alen Ježovnik

Koper $\cdot 2021$

(C) 2021 Viktorija Florjančič

Brezplačna spletna izdaja

https://www.hippocampus.si/ISBN/978-961-293-111-7.pdf

https://www.hippocampus.si/ISBN/978-961-293-112-4/index.html

https://doi.org/10.26493/978-961-293-111-7

\section{(cc) BY-SA}

Kataložni zapis o publikaciji (CIP) pripravili

$\mathrm{v}$ Narodni in univerzitetni knjižnici v Ljubljani

COBISS.SI-ID 84433155

IS B N 978-961-293-111-7 (pdf)

IS B N 978-961-293-112-4 (html) 


\section{Kazalo}

Seznam slik $\cdot 7$

Seznam preglednic $\cdot 9$

Zahvala $\cdot 11$

$1 \mathrm{Uvod} \cdot 13$

2 E-izobraževanje in študij na daljavo $\cdot 19$

2.1 Opredelitev osnovnih pojmov $\cdot 19$

2.2 Študij na daljavo v Sloveniji $\cdot 23$

2.3 Uporaba interneta med študentsko populacijo $\cdot 27$

3 E-izobraževanje na Univerzi na Primorskem · 31

3.1 Predstavitev Univerze na Primorskem · 31

3.2 Projekt InoTeZ - Inovativno s tehnologijo do znanja $\cdot 32$

3.3 Razumevanje in odnos do e-izobraževanja na UP $\cdot 35$

3.4 Odziv UP na prvi val epidemije covida-19. 45

4 E-izobraževanje na U P F M $\cdot 49$

4.1 Začetek in razvoj · 49

4.2 Izvedba pedagoškega procesa pred epidemijo $\cdot 51$

4.3 Izvedba pedagoškega procesa med epidemijo $\cdot 53$

5 Preverjanje in ocenjevanje znanja $\cdot 71$

5.1 Opredelitev osnovnih pojmov $\cdot 71$

5.2 Ocenjevanje v slovenski visokošolski zakonodaji $\cdot 72$

5.3 Uporaba IK T pri preverjanju in ocenjevanju znanja $\cdot 73$

5.4 Izzivi izvedbe izpitov na daljavo $\cdot 75$

5.5 Metodologija in raziskovalna vprašanja $\cdot 76$

5.6 Rezultati raziskave $\cdot 77$

5.7 Povzetek $\cdot 82$

6 Evalvacija izvedb predmetov s področja poslovne informatike $\cdot 85$

6.1 I K T praktikum $2019 / 2020 \cdot 86$

6.2 IK T praktikum 2020/2021 99

6.3 Primerjava uspešnosti študentov pri I K T praktikumu · 109

6.4 Poslovna informatika $\cdot 110$

7 Vrednotenje pedagoškega dela $\mathrm{v}$ visokem šolstvu $\cdot 131$ 7.1 Uvod $\cdot 131$ 
Kazalo

7.2 Pedagoško delo v normativnih aktih $\cdot 132$

7.3 Predlog vrednotenja dela pri delu na daljavo $\cdot 135$

8 Sklepna razmišljanja $\cdot 139$

Literatura $\cdot 145$

Priloge $\cdot 151$ 


\section{Seznam slik}

3.1 Podpora vodstva in vključenost I K T v pedagoški proces $\cdot 44$

4.1 Struktura e-učilnice za študijsko leto 2020/2021 · 52

4.2 Podpora študentom prejšnjih generacij za predmete s področja poslovne informatike $\cdot 54$

4.3 Aktivnost v e-učilnici U P F M 57

4.4 Podpora učiteljem v M S Teams 59

4.5 Exam.net - vprašanja $\cdot 64$

4.6 Exam.net - osebni podatki študenta $\cdot 65$

4.7 Exam.net - nastavitev študentovega delovnega okolja $\cdot 66$

4.8 Exam.net - varnostne nastavitve $\cdot 67$

4.9 Exam.net - vstop študenta $\cdot 68$

4.10 Študentski pogled na izpit v exam.net $\cdot 69$

4.11 Nadzorna plošča izpita $\cdot 69$

5.1 Raziskovalni okvir $\cdot 76$

5.2 Struktura Moodlovih izpitov 79

6.1 Študijska gradiva $\cdot 86$

6.2 E-gradivo (Excel in Word) $\cdot 87$

6.3 Zaznamki v interaktivnem videoposnetku $\cdot 87$

6.4 Statistika uporabe lekcije $\cdot 88$

6.5 I K T praktikum - teden pred prehodom na splet $\cdot 89$

6.6 Prehod na splet $\cdot 90$

6.7 Napovednika začetka srečanja v Arnes vox · 91

6.8 Posnetki srečanja na Arnes VoX · 91

6.9 Prehod z Arnes Vox-a na ZOoM $\cdot 92$

6.10 Posnetek na Arnesovem videoportalu · 92

6.11 Preverjanje in ocenjevanja znanja na daljavo $\cdot 94$

6.12 Videovodič opravljanja izpita $\cdot 94$

6.13 Obremenitev študentov po tednih $(2019 / 2020) \cdot 98$

6.14 Postavitev predmeta v e-učilnici $\cdot 100$

6.15 Podpora študentom $\cdot 101$

$6.16 \mathrm{zO}$ OM-ove spletne predavalnice $\cdot 102$

6.17 Primer ureditve teme v e-učilnici $\cdot 103$

6.18 Pregled izvedenih zO OM-ovih srečanj · 103

6.19 Pregled posnetkov Z O O M-ovih srečanj · 104

6.20 Obvestilo o izteku 9o-dnevnega roka $\cdot 104$ 
6.21 Prenos in povezava podatkov prisotnih študentov $\cdot 105$

6.22 Oddaja izpitne naloge in povezave do zo o M-ovega video posnetka 106

6.23 Z O O M-ova srečanja (mnenja študentov) $\cdot 106$

6.24 Primerjava tedenske obremenitve študentov 109

6.25 Ureditev e-učilnice - Poslovna informatika (U N 2019) · 111

6.26 Primer tedenske ureditve predmeta $\cdot 112$

6.27 Prednastavljene skupine za skupinsko delo v z O OM-u $\cdot 113$

6.28 Skupinsko delo v ločenih skupinah $\cdot 114$

6.29 Vabilo k aktivnemu odmoru v e-učilnici U P F M · 116

6.30 Izpitni protokol pri Poslovni informatiki · 119

6.31 Ureditev e-učilnice za kvartalni izpitni rok 119

6.32 Zajem slike s pametnega telefona med izpitom $\cdot 120$

6.33 Struktura ocene predmeta $\cdot 125$

6.34 Primerjava tedenske obremenitve študentov $\cdot 126$

6.35 Napredovanje študentov po izbranih učnih izidih 129 


\section{Seznam preglednic}

2.1 Delež rednih uporabnikov interneta med študenti · 28

2.2 Namen uporabe interneta med študentsko populacijo $\cdot 28$

3.1 Razumevanje e-izobraževanja in naklonjenost vodstva $\cdot 38$

3.2 Vključenost IK T v pedagoški proces in obstoječa podpora na fakulteti 40

3.3 Ovire za uporabo IK T v pedagoškem procesu $\cdot 42$

3.4 Podpora na ravni UP in odpiranje UP $\cdot 43$

3.5 Najpogosteje uporabljene tehnologije za nadomeščanje kontaktnih ur $\cdot 47$

4.1 Vpisani študentje v 1. letnik po študijskih programih U P F M · 51

4.2 Študentje UP F M po študijskih letih $\cdot 52$

4.3 Struktura najdejavnejših predmetov po letih $\cdot 56$

5.1 Tehnologija, uporabljena pri izvedbi izpitov na daljavo $\cdot 78$

5.2 Izzivi izpitov na daljavo $\cdot 80$

$5 \cdot 3$ Izpiti na daljavo $\mathrm{v}$ prihodnje $\cdot 81$

5.4 Izpiti v prihodnje $\cdot 82$

5.5 Spremembe po letu dni poučevanja na daljavo $\cdot 82$

6.1 Mnenja študentov I K T praktikuma o gradivih (2019/2020) 97

6.2 Študijske obveznosti pri I K T praktikumu (2019/2020) 97

6.3 Primerjava mnenj o gradivih $\cdot 107$

6.4 Primerjava mnenj o študijskih obveznostih $\cdot 108$

6.5 Primerjava uspešnosti študentov $\cdot 110$

6.6 Uspešnost študentov Poslovne informatike po letih · 111

6.7 Uspešnost študentov Poslovne informatike $(2020 / 2021) \cdot 121$

6.8 Odziv študentov na anketo o izvedbi predmeta $\cdot 122$

6.9 Z O O M-ova srečanja (mnenja študentov) $\cdot 122$

6.10 Primerjava mnenj o gradivih $\cdot 123$

6.11 Primernost študijskih obveznosti $\cdot 123$

6.12 Zahtevnost študijskih obveznosti $\cdot 124$

6.13 Uporaba I K T in zavedanje izzivov njene uporabe $\cdot 124$

6.14 E-izpiti - mnenja študentov 126

6.15 Povprečne vrednosti napredovanja študentov $\cdot 130$

7.1 Osnovni podatki predmetov $\cdot 136$

7.2 Preračun pedagoških ur v delovne ure $\cdot 136$

7.3 Simulacija pedagoške obremenitve šest K T predmetov $\cdot 137$ 



\section{Zahvala}

Uspešnih odzivov na epidemijo na Univerzi na Primorskem ne bi bilo brez projektne skupine InoTeZ - Inovativno s tehnologijo do znanja, predvsem mag. Šarolte Godnič Vičič in Saše Planinca z U P F T Š Turistice ter dr. Stanka Pelca z U P PE F, s katerimi smo virtualno preživeli številne neobičajne delovne in nedelovne ure. Skupaj smo iskrili možgane, testirali različne rešitve in sočustvovali, ko so bili poskusi neuspešni. Ob tem nam je na pomoč vedno priskočil dr. Jernej Vičič z U P FAM N IT, ki je skrbel, da so vse e-učilnice na U P ob povečani rabi delale brezhibno.

Posebna zahvala sodelavcu Matevžu Maleju, s katerim sva bila celotno koronsko obdobje v stiku več kot vsa leta prej. Skupno iskrenje možganov in testiranje rešitev z različnih naprav, ob vseh mogočih urah, je prineslo izpitne protokole, ki sva jih nesebično delila s celotnim slovenskim izobraževalnim prostorom.

In seveda pohvale vsem visokošolskim učiteljem in sodelavcem UP F M, ki so svoje delo čez noč prenesli na splet. 



\section{Uvod}

Monografija nastaja leto dni po razglasitvi prvega vala ${ }^{1}$ epidemije covida19 v Sloveniji. Vlada Republike Slovenije je 15. marca 2020 sprejela od$\operatorname{lok}^{2}$ o prepovedi zbiranja ljudi v vzgojno-izobraževalnih zavodih po celotni izobraževalni vertikali - od vrtcev do vključno visokega šolstva. Z izvajanjem dejavnosti so prenehale tudi organizacije, ki se ukvarjajo $z$ neformalnim izobraževanjem. Odlok vlade je posledica širjenja okužb $s$ koronavirusom, ki ga je svetovna zdravstvena organizacija zaradi podobnosti z virusom SARS poimenovala SARS-COV-2. ${ }^{3}$ Virus so konec leta 2019 odkrili v mestu Wuhan na Kitajskem. Zaradi globalizacije se je hitro širil po celem svetu. Konec januarja 2020 so bile okužbe s koronavirusom identificirane že v 18 državah izven Kitajske. ${ }^{4}$ Hitro širjenje virusa in resni zapleti obolelih so vlade številnih držav vzpodbudili $\mathrm{k}$ zapiranju javnega življenja in razglašanju epidemij. Glede na hitrost širjenja okužb je covid-19 hitro prerasel v pandemijo.

Zapiranje javnega življenja in dela, za kar se je, tudi izven anglosaških držav, uveljavilo poimenovanje »lockdown«, je vzpodbudilo delo na daljavo. Zaposleni so po spletu dostopali do službenih dokumentov, med seboj sodelovali in od doma opravljali svoje delo, če je to dopuščala narava dela. Po spletu so se začele izvajati številne dejavnosti, ne samo nakupovanje in komunikacija. Tja so se preselili tudi izvajanje rekreativne dejavnosti (različne vodene vadbe), umetniški nastopi, konference in seveda tudi izobraževalna dejavnost.

\footnotetext{
${ }^{1}$ Prvi val epidemije je bil preklican 15. 5. 2020, drugi val pa razglašen 18. 10. 2020 (https:// www.gov.si/novice/2020-10-19-vlada-razglasila-epidemijo-nalezljive-bolezni-covid-19 -na-obmocju-republike-slovenije/). Drugi val epidemije je trajal do 17. 4. 2021.

${ }^{2}$ Glej https://www.gov.si/novice/2020-03-15-posebno-obvestilo-ministrice-dr-simone -kustec-o-varstvu-otrok/.

${ }^{3}$ Glej https://www.who.int/emergencies/diseases/novel-coronavirus-2019/technical -guidance/naming-the-coronavirus-disease-(covid-2019)-and-the-virus-that -causes-it.

${ }^{4}$ Glej https://www.who.int/news/item/27-04-2020-who-timeline-covid-19.
} 
Razglasitev pandemije je povzročila globalno zapiranje šol različnih ravni. Marca 2020 je 850 milijonov posameznikov pridobivalo znanje izven klasičnih učilnic (Johnson, Veletsianos in Seaman 2020). Čeprav se je takšen način izobraževanja do takrat zdel rezerviran le za institucije, ki izobraževanje izvajajo na daljavo, pa se to ni zgodilo prvič. Johnsonova, Veletsianos in Seaman (2020) navajajo primere, ko se je izobraževalna dejavnost, zaradi naravnih nesreč ali različnih političnih pretresov, že izvajala na daljavo. Tako navajajo primere orkana Katrina avgusta 2005 V Z D A, potresa na Novi Zelandiji leta 2011 ter študentskih demonstracij v Južni Afriki leta 2015. Ti odzivi na izredne razmere so bili sicer omejeni na ožje geografsko področje. Pandemija covida-19 pa je v obliko dela na daljavo, na splet premaknila celotno globalno učečo se skupnost, kar se v zgodovini še ni zgodilo (Johnson, Veletsianos in Seaman 2020).

Izredne razmere so nepredvidljive, zaradi česar je tudi odziv nenaden, nepredvidljiv in nenačrtovan. Čeprav poučevanje poteka na daljavo, tega ne moremo poimenovati poučevanje (študij) na daljavo, saj tovrstno izobraževanje ni vnaprej načrtovano in pripravljeno. Tako se je v angleško govorečih državah uveljavil pojem emergency remote teaching, v slovenskem prostoru pa smo govorili o šoli/študiju na daljavo, nekateri so to poimenovali tudi krizno izobraževanje (Univerza v Ljubljani 2020), oziroma o krizni vzpostavitvi poučevanja na daljavo. ${ }^{5} \mathrm{Na}$ Univerzi na Primorskem (U P) smo govorili o kriznem poučevanju v izrednih razmerah in tako tudi poimenovali priporočila, ki bodo predstavljena kasneje. Ne glede na poimenovanje pa se je v času zaprtja šol izobraževanje izvajalo nenačrtovano, $z$ veliko mero eksperimentiranja in prilagajanja. Takšno izobraževanje se seveda razlikuje od načrtovanega in osmišljenega spletnega izobraževanja (Hodges idr. 2020).

Preučevanje odzivov izobraževalnih institucij na zapiranje šol se je začelo kmalu po razglasitvi pandemije. Tako so UNESCO, UNICEF in Svetovna banka (2020) od maja do sredine junija 2020 zbirali podatke o odzivu šol na izredne razmere. Na vprašalnike so se $v$ največji meri odzvale šole iz Azije, Afrike ter Srednje in Južne Amerike. Odziv šol iz Evrope in ZDA je bil skromen. Rezultatov raziskave sicer ne moremo posploševati, saj raziskava ni reprezentativna, so pa vseeno zanimivi za nadaljnje raziskovanje in sploh, ker gre za eno prvih raziskav o odzivih visokega šolstva na pandemijo. Podobno (nereprezentativno) razi-

${ }^{5}$ Glej https://it.um.si/novice/Strani/Podrobnosti-novice.aspx?nID=218. 
skavo, sicer med visokošolskimi organizacijami, je opravilo tudi Mednarodno združenje univerz (International Association of Universities - IAU), ki deluje v okviru UNESCA (Marinoni, van't Land in Jensen 2020). Raziskovalci se zavedajo, da bo za globlje razumevanje razmer $\mathrm{v}$ raziskavo potrebno vključiti večje število respondentov pa tudi zajeti daljše časovno obdobje. Po podatkih raziskave je zaradi pandemije svoja vrata zaprlo več kot $90 \%$ respondentov, ki so pedagoško dejavnost začeli izvajati na daljavo.

Primerjalna študija (Tejedor idr. 2021) odziva univerz Španije, Italije in Ekvadorja na nenadno zaprtje univerz je pokazala, da je, čeprav si učitelji in študentje želijo klasičnih oblik študija, zaprtje prineslo zavedanje o priložnostih, ki jih prenos izobraževanja na splet prinaša za inovacije na področju študijske dejavnosti.

UP je, zaradi bližine Italije, prvega (in največjega) žarišča virusa

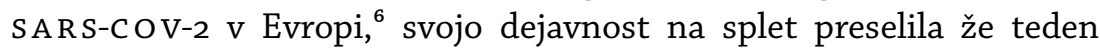
pred razglasitvijo epidemije $v$ Sloveniji. Učitelji smo se čez noč znašli v situaciji, ko smo izvajanje pedagoške dejavnosti morali prenesti na splet in delo začeli opravljati od doma. Na srečo so se na vseh treh javnih univerzah izvajali projekti ${ }^{7}$ vključevanja uporabe informacijskokomunikacijske tehnologije (I K T) v visokošolski pedagoški proces. Projekti (2017-2020) so se financirali iz sredstev Evropskega socialnega sklada (80\%) in Ministrstva za izobraževanje, znanost in šport (20\%). Projekt na U P smo poimenovali »InoTeZ - inovativno s tehnologijo do znanja«. Projektna skupina je že konec prvega tedna dela na daljavo pripravila priporočila za delo na daljavo v izrednih razmerah. Priporočila so bila posredovana vsem članicam U P, objavljena pa so tudi na portalu Odprta U P. ${ }^{8}$ Takšen način objave priporočil odpira možnosti za hitro prilagajanje priporočil, hkrati pa slednja odpira širši zainteresirani javnosti, kar je skladno s konceptom odpiranja univerze, za kar smo si prizadevali v okviru projekta InoTeZ. Priporočila so se na začetku nanašala le na komunikacijo $s$ študenti, način posredovanja znanja in sodelovalno delo s študenti. Kasneje pa smo jih razširili še $z$ napotki za izvedbo izpitov na daljavo.

\footnotetext{
${ }^{6}$ Glej https://www.cidrap.umn.edu/news-perspective/2020/o3/who-europe-now -worlds-covid-19-epicenter.

${ }^{7}$ Projekti InoTez na Univerzi na Primorskem (http://inotez.upr.si/), Didakt.UM na Univerzi v Mariboru (https://didakt.um.si/) in Digitalna univerza na Univerzi v Ljubljani (https://di.uni-lj.si/).

${ }^{8}$ Glej https://odprtaup.upr.si/mod/book/view.php?id=882.
} 
V monografiji predstavljamo odziv pretežno tradicionalne univerze na spletno poučevanje, ki je posledica širjenja okužb $z$ virusom SAR SCOV-2, s poudarkom na praksi U P Fakultete za management (U P F M). UP F M je namreč fakulteta $\mathrm{z}$ najdaljšim stažem uporabe IK T v pedagoški praksi na univerzi, saj je izvedbo pedagoškega procesa $z$ e-učilnico, kot imenujemo spletno učno okolje Moodle na U P F M, podprla že leta 2007/2008 (Trunk Širca in Sulčič 2010). Monografija predstavlja preplet rezultatov raziskav, primerov dobre rabe in priporočil za ravnanje v krizni situaciji, saj želimo, da bi izkušnje »koronskega leta" ne odšle v pozabo. Poleg tega želimo primere dobre rabe deliti s širšo izobraževalno skupnostjo in tako prispevati k razmisleku o metodah poučevanja v visokem šolstvu ter pomagati pri odločitvah visokošolskih zavodov o ravnanju v podobnih situacijah.

V monografiji najprej opredelimo izobraževanje in e-izobraževanje, ki ga postavimo ob bok izobraževanju (študiju) na daljavo, s predstavitvijo katerega zaključimo drugo poglavje.

V tretjem poglavju predstavljamo u P ter projekt InoTeZ, ki je imel pri prenosu poučevanja v obliko na daljavo pomembno vlogo. Predstavitev U P dopolnjujemo $\mathrm{z}$ rezultati raziskave o razumevanju e-izobraževanja na U P. Raziskava je bila opravljena v okviru projekta InoTeZ. Poglavje pa zaključujemo s poročilom o odzivu U P na izredne razmere.

$\mathrm{V}$ četrtem poglavju koronaizziv prenesemo na U P F M: predstavimo U P F M, način uvajanja ter uporabe I K T pred epidemijo ter odziv fakultete na spremenjene razmere zaradi epidemije. Predstavimo tudi osrednje tehnologije, ki smo jih uporabili na U P F M.

Preverjanju in ocenjevanju znanja smo namenili ločeno poglavje, saj predstavljata v obliki na daljavo poseben izziv za vse udeležence - učitelje, študente in visokošolski zavod. Medtem ko način izvedbe izpitov prikazujemo pri evalvaciji posameznih predmetov, smo $\mathrm{v}$ tem poglavju želeli prikazati teoretična ozadja preverjanja in ocenjevanja znanja v visokem šolstvu, s poudarkom na izzivih, ki izhajajo iz dela na daljavo. Poglavje zaključujemo $\mathrm{z}$ raziskavo o izvedbi izpitov na daljavo, opravljeno med učitelji na U P F M. Za učitelje na članici z najdaljšo prakso pri uporabi I K T v pedagoškem procesu so takšni izpiti, kljub nekaterim izkušnjam s poučevanjem po spletu, predstavljali velik izziv in jim niso naklonjeni, kot bi mogoče pričakovali. Ta oblika izpitov je izziv tudi za visokošolski zavod, ki mora poskrbeti za verodostojnost in veljavnost izpitov.

$\mathrm{V}$ drugem delu monografije predstavljamo evalvacijo izvedbe pred- 


\section{Uvod 1}

metov s področja poslovne informatike. Rezultati raziskav, predvsem pa uspešnost študentov odpirajo vprašanja o možnostih večjega vključevanja I K T v pedagoški proces, čemur trenutni sistem še ni naklonjen. Pri izvedbi na daljavo še vedno namreč ostajajo odprta vprašanja o obremenitvi učitelja, čemur namenimo zadnje poglavje. 



\section{E-izobraževanje in študij na daljavo}

\subsection{Opredelitev osnovnih pojmov}

Pri opredeljevanju e-izobraževanja pogosto srečamo različne opredelitve pa tudi poglede, kjer se prepleta način izvedbe s pristopom in dostopnostjo ter uporabljena tehnologija. Najstarejši pojem je študij (izobraževanje) na daljavo, ki se uporablja še danes, pogosto kar v kombinaciji z besedami »spletni«, »online« ali »elektronski« (okrajšano »e-«). Študij na daljavo ni nekaj, kar povezujemo s svetovnim spletom ali z internetom in računalniki, saj se je izvajal že v 19. stoletju (Simonson idr. 2011, 37-39). Takratni študij na daljavo je sicer poznan pod pojmom dopisno izobraževanje (angl. correspondence study), kar izobraževanju na daljavo pogosto daje negativno konotacijo. Dopisno izobraževanje je bilo namenjeno odraslim, ki se iz različnih razlogov (oddaljenost, zaposlenost, družinske in druge obveznosti) niso mogli vključiti v redno izobraževanje (Simonson idr. 2011, 37-39). Simonson idr. (2011, 39) navajajo dva filozofska pristopa pri dopisnem izobraževanju - popolnoma odprto izobraževanje (primer Hermods ${ }^{1}$ na Švedskem), ko učeči se po programu napreduje skladno s potrebami in sposobnostmi, ter nekoliko zaprtejše izobraževanje (primer univerze v Chicagu), ko se izobraževanje odvija po vnaprej postavljenem tedenskem načrtu (urniku). Izobraževanje (študij) na daljavo že od vsega začetka nudi možnosti za posodabljanje znanja, hkrati pa učečemu se omogoča prilagodljivost v času in prostoru (Simonson idr. 2011, 39). Prostorska in časovna ločenost učečega se (študenta) in učitelja pri študiju na daljavo je ena izmed osnovnih značilnosti slednjega, ki jo izpostavlja že Keegan (1990). Ravno ta značilnost študij na daljavo razlikuje od klasično izvedenega študija $\mathrm{v}$ predavalnici, kjer so učeči se in učitelj sočasno v predavalnici. Poleg prostorske in časovne ločenosti je za študij na daljavo značilno, da je študij načrtovan, organiziran in izveden skladno s študijskim programom in $\mathrm{z}$ učnimi načrti posameznih predmetov. Načrtovana in nadzorovana sta

\footnotetext{
${ }^{1}$ Glej https://www.hermods.se/.
} 
tudi preverjanje in ocenjevanje znanja. Te značilnosti študij na daljavo razlikujejo od samoizobraževanja, ko si učeči se znanje pridobiva sam. Sodobni študij na daljavo omogoča tudi dvosmerno komunikacijo med vsemi udeleženci pedagoškega procesa (učitelja s študenti in med študenti).

V primeru dopisnega izobraževanja sta bila učeči se in institucija (učitelj) povezana po klasični pošti. Klasična pošta se je uporabljala za posredovanje učnih gradiv in navodil za študij, za posredovanje opravljenih obveznosti (nalog) ter tudi za (enosmerno) komunikacijo. Z razvojem tehnologije so se v študij na daljavo vključevale nove tehnologije, telefon, radio in televizija (t.i. teleizobraževanje), ki so postopno dopolnjevale in/ali nadomeščale klasično pošto. $Z$ razvojem računalniških omrežij, predvsem interneta, in v 9o. letih prejšnjega stoletja še svetovnega spleta je študij na daljavo dobil dodatne možnosti in priložnosti. Svetovni splet je olajšal posredovanje gradiv, opravljanje študijskih obveznosti, spremljanje napredka študentov; predvsem pa je omogočil dvosmerno komunikacijo. Komunikacija je lahko asinhrona (komunikacija ne poteka v času) ali/in sinhrona (sodelujoči so istočasno prisotni $\mathrm{v}$ virtualnem ali realnem prostoru). $Z$ ustvarjanjem mentorsko podprtih učečih se skupnosti postaja študij na daljavo pogosto celo učinkovitejši od klasičnega študija.

Študij (izobraževanje) na daljavo je tako način izvedbe pedagoške dela, pri katerem (Keegan 1990; Simonson idr. 2011):

- pedagoški proces načrtuje, organizira in izvaja izobraževalna organizacija;

- sta učitelj in učeči se prostorsko in časovno ločena;

- sta učitelj in učeči se, kljub prostorski in časovni ločenosti, povezana, komunikacija med udeleženci pa je lahko sinhrona in/ali asinhrona;

- se med učečimi se in učiteljem oblikuje t.i. učeča se skupnost, ki temelji na dvosmerni interakciji, sodelovanju in komunikaciji.

Tehnologija tako predstavlja medij, ki medsebojno povezuje vse udeležence učeče se skupnosti (Fee 2009). Bates (2005) v I K T vidi ključno sestavino izvedbe študija na daljavo. Pri tem soglaša s Kaufmanom (1989 v Bates 2005, 6) in Nipperjem (1989 v Bates 2005, 6) ter študij na daljavo razvršča v tri generacije (Bates 2005, 6-8).

V prvi generaciji študija na daljavo je tehnologija omogočala posredovanje študijskih vsebin od organizacije do študenta. Bates $(2005,6)$ v to 
obdobje uvršča radio in televizijo, čeprav izobraževanje večinoma temelji na tiskanih gradivih. Obseg komunikacije med študenti in učiteljem je minimalen.

Druga generacija študija na daljavo vključuje različne tehnologije pa tudi intenzivnejšo komunikacijo s študenti. Za komunikacijo je zadolžen mentor (tutor) in ne učitelj predmeta. Za to generacijo so značilna, posebej za ta namen pripravljena, učna gradiva za samostojni študij; študijski proces je natančno strukturiran in izpeljan. Peters (1983 v Bates 2005,7$)$ zato govori o industrijskem načinu izobraževanja, saj je takšen način izobraževanja v veliki meri standardiziran in formaliziran ter tako sledi načelom ekonomije obsega. Način izvedbe izobraževanja omogoča vključevanje velikega števila študentov ter kot takšen predstavlja nov poslovni model na področju izobraževanja (Peters 1997). Daniel $(1996$ v Bates 2005, 7) univerze $z$ več 100.000 študenti poimenuje »megauniverze«. Bates (2005) v to obdobje vključuje znane univerze študija na daljavo, kot so britanska Odprta univerza (The Open University), ${ }^{2}$ turška odprta univerza Anadolu ${ }^{3}$ in španska državna Univerza za študij na daljavo (Universidad de Educaciòn à Distancia - U NED). ${ }^{4}$

Tretja generacija študija na daljavo temelji na dvosmerni komunikaciji po internetu. Komunikacija ni naključna, temveč je podprta in usmerjana. Značilnost te generacije je ravno enakovredno porazdeljena komunikacija med vsemi udeleženci študijskega procesa. Torej nimamo več le posredovanja navodil s strani učitelja kot tudi ne samo komunikacije med študenti, temveč komunikacija poteka med študenti ter med študenti in učiteljem. Tretjo generacijo pogosto imenujejo kar na znanju temelječi sistem študija na daljavo ali postindustrijski sistem študija na daljavo (Bates 2005, 7). Če so bili predmeti prej namenjeni veliki skupini študentov, kjer je bilo vse podrobno načrtovano in standardizirano (industrijski pristop) ter je bil zato razvoj takšnih predmetov (programov) finančno zahteven, pa so predmeti sedaj prilagodljivi, ustvarjajo jih manjše skupine ljudi, njihov razvoj pa ne zahteva visokih finančnih vložkov. Izobraževanje v tretji generaciji študija na daljavo je značilno za tradicionalne univerze, ki šele uvajajo študij na daljavo (angl. dual mode institutions). Poučevanje v sistemu študija na daljavo večinoma temelji na konstruktivistični teoriji učenja (Bates 2005, 7).

\footnotetext{
${ }^{2}$ Glej http://www.openuniversity.edu/.

${ }^{3}$ Glej https://www.anadolu.edu.tr/en.

${ }^{4}$ Glej https://www.uned.es/universidad/inicio.html.
} 
Fee (2009) poudarja pomen e-izobraževanja v t. i. družbi znanja. Tehnologija sicer predstavlja sestavino e-izobraževanja, vendar le kot sredstvo za izvedbo učne izkušnje ter kot orodje za posredovanje učnih vsebin, komunikacijo in sodelovanje. Osrednja sestavina e-izobraževanja so še vedno pedagoški in didaktični pristopi učitelja. E-izobraževanje učno izkušnjo usmeri $\mathrm{k}$ učečemu se, pomaga razvijati kulturo učenja, gradi učečo se skupnost in opolnomoči učeče se (Fee 2009).

Začetki študija na daljavo v Sloveniji so povezani s programom Phare (1995-1999), v katerega je bilo vključenih 11 držav srednje in vzhodne Evrope (Bregar in Zagmajster 2003). Prek programa so se uresničevale smernice E U za razvoj študija na daljavo kot ene izmed prednostnih nalog na področju izobraževanja (Bregar in Zagmajster 2003). Študij na daljavo se je promoviral prek programa L O L A (angl. Learning About Open Learning), ki je udeležence, prek vsebin in načina izvedbe, usposobil za razvoj in izvedbo študija na daljavo. Tako se je študij na daljavo najprej vzpostavil na Ekonomski fakulteti Univerze v Ljubljani. Za izvedbo t. i. tradicionalnega študija na daljavo (študij se ne izvaja po spletu) so razvili študijski program Visoke poslovne šole (Zagmajster 2006). Za ta namen so bila, v okviru projekta Phare, razvita tudi številna študijska gradiva za samostojni študij študentov. Prvi t.i. online študij, študij na daljavo po internetu, pa je ponudila Doba iz Maribora v letu 1999 (Doba 2020). Doba je študij na daljavo po spletu vpeljala v višješolske študijske programe (Sulčič 2001). V letu 2021 Doba po spletu izvaja 17 študijskih programov: šest višješolskih, pet dodiplomskih in ravno toliko podiplomskih študijskih programov ter tudi doktorski študij. ${ }^{5} \mathrm{Na}$ spletni strani fakultete se pohvalijo tudi $\mathrm{z}$ dvema mednarodnima akreditacijama online študija, s čimer so vodilna tovrstna institucija v Sloveniji in, upali bi si trditi, sinonim za študij na daljavo v Sloveniji. Na spletni strani izpostavljajo, da so »edina fakulteta $z$ dvema mednarodnima akreditacijama kakovosti online študija v jugovzhodni Evropi«. ${ }^{6}$ Doba je leta 2013 prejela certifikat UNIQU e za kakovost e-izobraževanja, ki ga je podelila fundacija EFQUEL (European Foundation for Quality in e-Learning), ${ }^{7}$ certifikat E O c C S (Online Course Certification System) pa

\footnotetext{
${ }^{5}$ Glej https://www.doba.si/online-studij-doba.

${ }^{6}$ Glej https://www.fakulteta.doba.si/novice/mednarodna-akreditacija-online-studija.

${ }^{7}$ Glej https://e-profman.eu/doba in https://web.archive.org/web/20150919023905 /http://unique.efquel.org/2013/10/10/doba-awarded-unique-certification/-fundacija E F QUEL je nehala delovati leta 2015 (https://www.bircham.net/efquel-european -foundation-for-quality-in-elearning.html).
} 
so prejeli za predmet Communication and Lobbying, ki je del magistrskega študijskega programa Mednarodno poslovanje. ${ }^{8}$

\section{2 Študij na daljavo v Sloveniji}

Razširjenost študija na daljavo v Sloveniji smo raziskali po dveh kanalih - iskanje $\mathrm{z}$ iskalnikom Google in pregled razpisa za vpis za študijsko leto 2021/2022. Iskanje $z$ iskalnikom Google je potekalo 5. maja $21 \mathrm{~s} \mathrm{po-}$ močjo ključne besede »študij na daljavo«. Poleg zavoda Doba smo našli še naslednje ponudnike študija na daljavo v Sloveniji (izključili smo oglaševane objave - oznaka Ad):

- Fakulteta za upravo Univerze v Ljubljani na daljavo izvaja študijski program 1. stopnje Uprava. ${ }^{9}$

- Fakulteta za industrijski inženiring Novo mesto ${ }^{10}$ na daljavo izvaja študij strojništva. Po podatkih s spletne strani fakultete se laboratorijske vaje izvajajo na sedežu fakultete ali v podjetjih, $s$ katerimi ima fakulteta sklenjene pogodbe, medtem ko se vse ostalo izvaja po spletu, vključno s preverjanjem znanja.

- Zasebni izobraževalni zavod Erudio je študij na daljavo začel ponujati v študijskem letu 2011/2012. ${ }^{11} \mathrm{Na}$ spletni strani oglašujejo t. i. »fleksi online študij« (prilagodljiv študij), kjer imajo študentje dostop do spletnih gradiv, predavanja so lahko klasična ali spletna, študentje pa imajo možnost ogleda posnetkov predavanj. Študentje lahko izberejo t. i. "premium online« študij, ki prilagodljiv študij nadgrajuje z možnostjo opravljanja izpitov online. Takšen način študija ponujajo $\mathrm{v}$ višješolskih in visokošolskih študijskih programih.

- Academia iz Maribora ${ }^{12}$ na daljavo izvaja višješolske študijske programe Ekonomist, Informatika, Gradbeništvo, Strojništvo in Varovanje.

- IBS - Mednarodna poslovna šola Ljubljana ${ }^{13}$ študij na daljavo omogoča vsem, ki jim domače ali službene obveznosti ne omo-

\footnotetext{
${ }^{8}$ Glej https://www.efmdglobal.org/assessments/online-courses/eoccs/eoccs-certified -courses/.

${ }^{9}$ Glej https://www.fu.uni-lj.si/programi/esd/.

${ }^{10}$ Glej http://www.fini-unm.si/studij/studij-na-daljavo/.

${ }^{11}$ Glej https://www.erudio.si/.

${ }^{12}$ Glej https://www.academia.si/studij-na-daljavo.

${ }^{13}$ Glej http://www.ibs.si/index.php/sl/tudij-na-daljavo.
} 
gočajo spremljanja študija na fakulteti. Izpiti se opravljajo skupaj s študenti klasičnega študija.

Opisi in ponudba posameznikih ponudnikov so bili zbrani s spletnih strani zavodov na dan zbiranja podatkov (5. maja 2021).

Ponudbo dodiplomskega študija na daljavo na javnih in visokošolskih zavodih s koncesijo smo preverili še v razpisu za vpis za študijsko leto 2021/2022 na portalu eVš. ${ }^{14}$ Po besedilu smo se pomikali z iskanjem ključnih besed: »online«, »e-«, »na daljavo«. V nadaljevanju prikazujemo podatke iz razpisa, pri čemer uporabljamo terminologijo zavoda.

\section{Univerza v Ljubljani}

- Ekonomska fakulteta predvideva online izvedbo rednega študija v primeru neugodnih epidemioloških razmer, za izvedbo izrednega študija pa predvideva kombinacijo izvedbe klasičnega in online študija. Za izredni študij razpisujejo 80 vpisnih mest; študij bodo izvajali, če bo vpisanih vsaj 20 kandidatov.

- Fakulteta za upravo razpisuje izredni študij kot e-študij na daljavo. Le-ta se izvaja "v vnaprej določenih časovnih obdobjih, opredeljenih s terminskim načrtom izvedbe«. Preverjanje znanja na eštudiju poteka $\mathrm{v}$ klasični obliki. Za izredni študij so razpisali 50 mest; študij bodo izvajali, če bo vpisanih vsaj deset kandidatov.

\section{Univerza v Mariboru}

- Fakulteta za organizacijske vede Kranj razpisuje univerzitetne študijske programe Inženiring poslovnih sistemov, Organizacija in management kadrovskih in izobraževalnih sistemov ter Organizacija in management informacijskih sistemov kot redni študij. Pri tem navaja, da se bodo predmeti »do $55 \%$ izvajali na daljavo v obliki e-izobraževanja«. Na vsakem od študijskih programov razpisujejo po 40 mest. Istoimenske programe izvajajo tudi kot visokošolske strokovne programe. Način izvedbe je enak kot na univerzitetnih programih, razpisujejo pa redni in izrednih študij (na program je razpisanih 6o mest rednega in po 30 mest izrednega študija). Enak način izvedbe predmetov je predviden tudi za visokošolska strokovna študijska programa Management v športu (razpisanih je 30 mest na izrednem študiju) in Krizni management (razpisanih 25 mest na izrednem študiju).

\footnotetext{
${ }^{14}$ Glej https://portal.evs.gov.si/razpisi-za-vpis-javni-koncesionirani.
} 


\section{Univerza v Novem mestu}

- Fakulteta za ekonomijo in informatiko razpisuje visokošolski študijski program Upravljanje in poslovanje ter študijski program Poslovna informatika. Na obeh študijskih programih e-študij predvideva na izrednem študiju, v kolikor bo vpisanih manj kot 15 študentov. Za izredni študij študijskega programa Upravljanje in poslovanje razpisujejo 40, na programu Poslovna informatika pa 20 vpisnih mest.

Univerza na Primorskem, Univerza v Novi Gorici ${ }^{15}$ ter Nova univerza ne razpisujejo študijskih programov, ki bi se delno ali v celoti izvajali na daljavo oziroma po spleta. Enako velja za samostojne visokošolske zavode, katerih študijski programi imajo koncesijo.

Pregledali smo še razpise za vpis zasebnih visokošolskih zavodov, ki ponujajo študijske programe brez koncesije. V nadaljevanju navajamo le razpise za dodiplomske študijske programe, pri tem pa opredelitve študija povzemamo po razpisnem besedilu.

Alma Mater Europaea - Evropski center Maribor razpisuje visokošolski strokovni študijski program Socialna gerontologija ločeno za izredni študij in za študij na daljavo. Za klasični izredni študij, ki ga izvajajo na treh lokacijah (Maribor, Koper in Ljubljana), razpisujejo 100 vpisnih mest, za študij na daljavo pa 40 vpisnih mest. Študij na daljavo izvajajo kot kombinacijo predavanj in vaj v živo ter na daljavo. Študente pri študiju na daljavo podpira mentor. Študij je namenjen študentom, ki se ne morejo udeležiti izvedbe klasično izvedenega izrednega študija. Razpis omenja, da se vsa predavanja na izrednem študiju snemajo, tako da si jih je možno ogledati tudi kasneje. Predvidevamo, da so ti posnetki na voljo študentom študija na daljavo. Na enak način Alma Mater Europea razpisuje izredni študij in študij na daljavo na visokošolskih strokovnih študijskih programih Management poslovnih sistemov (po 40 mest za izredni in za študij na daljavo), Arhivistika (30 mest za izredni študij, 30 mest za študij na daljavo) ter Spletne in informacijske tehnologije (9o mest za izredni študij - štiri lokacije in 20 na daljavo). Naj samo omenimo, da Alma Mater Europea študij na daljavo razpisuje tudi na magistrskem podiplomskem in doktorskem študiju.

\footnotetext{
${ }^{15}$ Univerza v Novi Gorici na svojih spletnih straneh (http://www.ung.si/sl/studij/vabilok-vpisu/poucevanje_na_daljavo/) sicer omenja, da bo ponudbo možnosti učenja na daljavo še povečala, vendar študija na daljavo, ki ga omenja na spletnih straneh, formalno ne razpisuje.
} 
Doba iz Maribora, kot omenjeno, študij na daljavo razpisuje kot online študij. Študentje se vanj lahko vpišejo na visokošolskih strokovnih študijskih programih Menedžment $\mathrm{v}$ sodobnem poslovanju (150 vpisnih mest), Marketing, družbeni mediji in odnosi z javnostmi (130 mest), Menedžment v sociali in izobraževanju (6o mest), Poslovanje in upravljanje v turizmu (55 mest) ter Uporabna psihologija (9o mest).

Visokošolsko središče Erudio razpisuje »izredni študij v klasični in kombinirani oz. e-obliki«. Študentom daje možnost, da se med letom odločijo za prehod s klasičnega na kombinirani študij. Iz razpisa za vpis ni razvidno, koliko mest je razpisanih za klasični in koliko za t.i. kombinirani študij. Za vpis $\mathrm{v}$ 1. letnik razpisujejo po 80 mest na študijskem programu Podjetništvo in mednarodno poslovanje ter na študijskem programu Trajnostni turizem.

Fakulteta za industrijski inženiring Novo mesto razpisuje vpisna mesta za študij na daljavo, ki ga izvajajo poleg rednega in izrednega študija. Študij na daljavo izvajajo kombinirano - po spletu in fizično na sedežu fakultete. Za študijsko leto 2021/2022 za izredni študij v obliki študija na daljavo razpisujejo 140 vpisnih mest na visokošolskem strokovnem študijskem programu Inženiring in vozila in 120 mest na istoimenskem univerzitetnem študijskem programu.

Fakulteta za komercialne in poslovne vede iz Celja na daljavo izvaja izredni študij visokošolskega strokovnega študijskega programa Poslovna informatika (100 vpisnih mest). Izredni študij izvajajo kombinirano - klasično in po spletu. Enako izvajajo visokošolski strokovni študijski program Turizem (180 vpisnih mest) in študijski program Varnostni menedžment (120 mest).

Gea College - Fakulteta za podjetništvo študij na daljavo razpisuje na visokošolskem strokovnem študijskem programu Digitalni marketing (40 mest) in na visokošolskem strokovnem študijskem programu Podjetništvo v perspektivnih panogah (40 mest).

Študij na daljavo na visokošolskem strokovnem študijskem programu Multimedijska produkcija razpisuje IAM visoka šola za multimedije v Ljubljani (30 razpisnih mest).

I B S Mednarodna poslovna šola Ljubljana študij na daljavo izvaja kot kombiniran študij, v razpisu pa omenja, da se tudi na izrednem študiju posamezni deli študijskega programa izvajajo »z elementi študija na daljavo«. V visokošolskem strokovnem študijskem programu Mednarodno poslovanje razpisujejo 20 vpisnih mest.

O e-študiju v visokem šolstvu smo podoben pregled opravili že pred 
sedmimi leti (Florjančič 2014), vendar ugotavljamo, da se situacija v Sloveniji, kljub izkušnji poučevanja na daljavo zaradi epidemije, ni bistveno spremenila. Ponudba študija na daljavo (ne glede na poimenovanje študija) ostaja omejena na posamezne primere in še to samo na izvedbo izrednega študija, ki je plačljiv. Odpiramo vprašanje, zakaj se takšen način študija ne omogoča kot brezplačni redni študij, kar bi bilo zanimivo za študente, ki se ne morejo udeležiti študija na lokaciji visokošolskega zavoda - gibalno ovirane študente, vrhunske športnike, mlade starše, ki skrbijo za majhne otroke ali starejše, študente s pravico do brezplačnega šolanja, ki pa nimajo sredstev za bivanje izven domačega kraja ipd.

\subsection{Uporaba interneta med študentsko populacijo}

Podatke o uporabi interneta in svetovnega spleta, po različnih kriterijih in $\mathrm{z}$ različnih vidikov, zbira Eurostat. ${ }^{16}$ Podatki se sicer objavljajo $\mathrm{z}$ zamudo, vendar ima Eurostat nekatere za leto 2020 že zbrane. Podatki Eurostata so zanimivi, saj omogočajo primerjavo med posameznimi državami in umestitev Slovenije v povprečje E U. V okviru priprave monografije nas je zanimala primerjava Slovenije s povprečjem držav E U ter tudi primerjava s sosednjimi državami, predvsem pa, ali so v letu 2020 zabeležene spremembe, ki bi jih lahko povezovali z zaprtjem šol.

Na portalu Eurostat smo zbrali podatke o študentski populaciji za leti 2019 in 2020 . Glede na to, da za leto 2020 ni podatkov za E U $28,{ }^{17}$ prikazujemo podatke za povprečje 27 držav E U (E U 27). Na ravni E U 27 je delež rednih uporabnikov interneta ${ }^{18}$ med študentsko populacijo $74 \%$ (leta 2019 je bil $72 \%$ ). Med sosednjimi državami Italija, Hrvaška in Avstrija beležijo dvig rednih uporabnikov interneta med študentsko populacijo za dve odstotni točki, med študentsko populacijo na Madžarskem in v Sloveniji je porast večji (preglednica 2.1).

Zanimivo je, da je delež rednih uporabnikov interneta $v$ Italiji precej nižji od povprečja E U 27. Čeprav je Slovenija v letu 2020 prišla nad povprečje držav E U 27, pa zaostaja za Avstrijo, Madžarsko in Hrvaško. Največ rednih uporabnikov interneta med študenti je na Hrvaškem (88\%) (preglednica 2.1).

\footnotetext{
${ }^{16}$ Glej https://ec.europa.eu/eurostat/web/main/data/database.

${ }^{17}$ Konec januarja 2020 se je zaradi izstopa Združenega kraljestva (Brexit) število članic EU zmanjšalo za eno članico.

${ }^{18}$ Redni uporabnik interneta je uporabnik, ki je internet uporabljal v zadnjih treh mesecih pred zbiranjem podatkov.
} 
Preglednica 2.1 Delež rednih uporabnikov interneta med študenti

\begin{tabular}{lllllll}
\hline Leto & EU 27 & Italija & Hrvaška & Avstrija & Madžarska & Slovenija \\
\hline 2019 & 72 & 60 & 86 & 80 & 75 & 70 \\
2020 & 74 & 62 & 88 & 82 & 83 & 79 \\
\hline
\end{tabular}

OPOMBE Vodstotkih.

Preglednica 2.2 Namen uporabe interneta med študentsko populacijo

\begin{tabular}{|c|c|c|c|c|c|c|c|c|c|}
\hline \multirow[t]{2}{*}{$\begin{array}{l}\text { Geografsko } \\
\text { področje }\end{array}$} & \multicolumn{3}{|c|}{$\begin{array}{l}\text { E-učna gradiva } \\
\text { (I_IUOLM) }\end{array}$} & \multicolumn{3}{|c|}{$\begin{array}{c}\text { Komunikacija z } \\
\text { učiteljem/študenti } \\
\text { (I_IUOCIS) }\end{array}$} & \multicolumn{3}{|c|}{$\begin{array}{l}\text { Online tečaj } \\
\text { ali e-gradiva } \\
\text { (I_IUOLANY) }\end{array}$} \\
\hline & 2019 & 2020 & Indeks & 2019 & 2020 & $\overline{\text { Indeks }}$ & 2019 & 2020 & Indeks \\
\hline E U 27 & 48 & 65 & 135,4 & 41 & 71 & 173,2 & 52 & 70 & 134,6 \\
\hline Italija & 53 & 72 & 135,9 & 56 & 82 & 146,4 & 55 & 75 & 136,4 \\
\hline Hrvaška & 70 & 82 & 117,1 & 30 & 78 & 260,0 & 49 & 66 & 134,7 \\
\hline Avstrija & 70 & 82 & 117,1 & 39 & 86 & 220,5 & 73 & 86 & 117,8 \\
\hline Madžarska & 25 & 59 & 236,0 & 26 & 76 & 292,3 & 29 & 65 & 224,1 \\
\hline Slovenija & 62 & 75 & 121,0 & 23 & 34 & 147,8 & 63 & 77 & 122,2 \\
\hline
\end{tabular}

OP OMBE Delež rednih uporabnikov interneta v odstotkih po podatkih Eurostata (https://ec.europa.eu/eurostat). V oklepaju je koda spremenljivke, kot jo poimenuje Eurostat.

Iz podatkov, ki jih Eurostat zbira o študentski populaciji in namenu uporabe interneta med rednimi uporabniki, smo zbrali podatke, povezane s pridobivanjem znanja (preglednica 2.2). V letu 2020 se je med študenti vseh držav in posledično na ravni držav E U 27 povečala uporaba interneta na področjih pridobivanja učnih gradiv na spletu (e-učna gradiva), komunikacije $\mathrm{z}$ učitelji ali s študijskimi kolegi in vključitve $\mathrm{v}$ online tečaje. Najbolj se je povečal delež rednih uporabnikov interneta na področju komunikacije (povprečje E U 27 za 73,2 \%, na Hrvaškem celo $160 \%$, v Sloveniji 47,8\%). Zanimivo je, da je največji porast zabeležen pri študentski populaciji Madžarske, tudi na področju komunikacije, kjer je bil delež študentov v letu 2019 le 3 odstotne točke nad deležem slovenskih študentov (preglednica 2.2).

Zaradi pandemije se je večina študentske populacije izobraževala na daljavo. Podatki Eurostata kažejo velik porast uporabe interneta med študentsko populacijo. Zanimivo je, da je delež slovenskih študentov, ki uporabljajo internet za komunikacijo $\mathrm{z}$ učiteljem ali s študijskimi kolegi, najnižji (34\%) med državami E U 27, čeprav so slovenski študentje nad povprečjem držav E U 27 pri vključitvi v kateri koli online tečaj (S LO: $77 \%$, E U $27=70 \%$ ) in pri iskanju e-gradiv na spletu (S L O: $75 \%$, E U $27=$ 
65\%) (preglednica 2.2). Glede na to, da so bili podatki o komunikaciji z učitelji ali s študenti prek spletnih portalov za slovenske študente tudi v preteklih letih podobno nizki, ${ }^{19}$ se postavlja vprašanja o načinu izvajanja študija na daljavo v letu 2020, ko se je celotna izvedba študija preselila na splet. Če je bil nizek delež komunikacije v preteklih letih še lahko povezan $z$ večinsko tradicionalnim načinom izvajanja študija $v$ slovenskih visokošolskih zavodih, kar smo predstavili v prejšnjem poglavju, pa podatek za leto 2020 zbuja skrb, da se je študij na daljavo izvajal pretežno s posredovanjem učnih gradiv študentom in ob minimalni spletni komunikaciji med učitelji in študenti ter med samimi študenti.

${ }^{19}$ Leta 2015 31\%, $201629 \%, 201730 \%$. 



\section{E-izobraževanje na Univerzi na Primorskem}

Univerza na Primorskem za študijsko leto 2021/2022 ne razpisuje študija na daljavo, kot tudi ne e-študija ali online študija. V nadaljevanju predstavljamo osnovne podatke o univerzi kot tudi stanje na področju e-izobraževanja.

\subsection{Predstavitev Univerze na Primorskem}

Univerza na Primorskem (U P), najmlajša in najmanjša slovenska javna univerza, je bila ustanovljena leta 2003. ${ }^{1}$ Ob nastanku U P so se pod okrilje univerze združili že prej nastali visokošolski zavodi: ${ }^{2}$

- Visoka šola za hotelirstvo in turizem Portorož (ustanovljena 1994), od leta 2008 Fakulteta za turistične študije - Turistica (U P F T Š Turistica), ${ }^{3}$

- Visoka šola za management (ustanovljena 1995), od leta 2003 Fakulteta za management (U P F M), ${ }^{4}$

- Fakulteta za humanistične študije (ustanovljena 2000) (U P FH Š) in

- Visoka šola za zdravstvo (ustanovljena 2002), od leta 2011 Fakulteta za vede o zdravju (U P FVZ). ${ }^{5}$

Leta 2003 je bila ustanovljena Pedagoška fakulteta (U P P E F) ${ }^{6}$ in 2006 še Fakulteta za matematiko, naravoslovje in informacijske tehnologije (UP FAMNIT). ${ }^{7}$ V UP je tako združenih šest pedagoških članic, ki ponujajo študijske programe na vseh treh bolonjskih stopnjah.

${ }^{1}$ Glej https://www.upr.si/si/univerza/univerza-v-stevilkah/.

${ }^{2}$ Podatki o nastanku in preoblikovanju posameznih zavodov so pridobljenih s spletnih strani zavodov.

${ }^{3}$ Glej https://www.turistica.si/si/o-nas/zgodovina/.

${ }^{4}$ Glej http://www.fm-kp.si/predstavitev/mejniki_v_razvoju.

${ }^{5}$ Glej https://fvz.upr.si/fakulteta/poslanstvo-in-vizija/.

${ }^{6}$ Glej https://www.pef.upr.si/predstavitev_fakultete/predstavitev/.

${ }^{7}$ Glej https://www.famnit.upr.si/sl/o-fakulteti. 
Konec oktobra 2020 je bilo na UP vpisanih 6.089 študentov, ${ }^{8}$ kar predstavlja $7,9 \%$ celotne študentske populacije v Sloveniji, oziroma 9,6\% študentske populacije slovenskih javnih višjih strokovnih in visokošolskih javnih zavodov. ${ }^{9}$

\subsection{Projekt InoTeZ - Inovativno s tehnologijo do znanja \\ Predstavitev projekta}

Ministrstvo za izobraževanje, znanost in šport (M I Z š) je leta 2017 razpisalo projekte vključevanja uporabe informacijsko-komunikacijske tehnologije (I KT) v visokošolski pedagoški proces. Na razpis so se lahko prijavili le javni visokošolski zavodi. Sredstva za projekte je v $80 \%$ zagotavljal Evropski socialni sklad, preostanek pa MIZš. Na razpis so se prijavile vse tri javne univerze, ki so morale zasledovati cilje, opredeljene v razpisu. Projekti so trajali do 30. 9. 2020.

$\mathrm{Na}$ U P smo projekt poimenovali »InoTeZ - inovativno s tehnologijo do znanja«, vanj pa smo vključili vse pedagoške članice UP:

- UP FHŠ,

- UP FM,

- UP FAMNIT,

- UP PEF,

- UP FTŠ Turistico,

- UP FVZ.

V projektu smo, med drugim:

- Opravili popis stanja s tehničnega ter pedagoško-didaktičnega vidika. Del slednjega je bila tudi raziskava razumevanja e-izobraževanja ter odnos članic, predvsem vodstva članic, do uporabe I K T v pedagoškem procesu, kar predstavljamo $\mathrm{v}$ nadaljevanju.

- Pripravili portal Odprta U P kot osrednje stičišče za širjenje primerov dobre rabe. Primere dobre rabe smo širili tudi prek spletne strani ${ }^{10}$ oziroma spletnega dnevnika (bloga) projekta. Dobra praksa in uporabna priporočila so širši izobraževalni skupnosti prosto dostopni tudi po zaključku projekta.

\footnotetext{
${ }^{8}$ Glej https://www.upr.si/si/univerza/univerza-v-stevilkah/.

${ }^{9}$ Glej https://pxweb.stat.si/SiStat/sl/Podrocja/Index/192/izobrazevanje.

${ }^{10}$ Glej https://inotez.upr.si.
} 
- Izvedli štiri konference, imenovane »Lastovke U P« ${ }^{11}$ kjer so učitelji lahko izmenjali svoje izkušnje. Zaradi epidemije sta bili zadnji dve konferenci izvedeni po spletu.

- Pripravili Minimalne standarde za uporabo e-učilnic na UP, saj smo po izvedenem posnetku stanja ugotovili, da se e-učilnice po članicah univerze različno intenzivno uporabljajo. Za nadaljnje vključevanje IKT $\mathrm{v}$ pedagoško prakso pa je potrebno vse članice pripeljati vsaj na približno enako raven uporabe I K T.

Podobna projekta so izpeljali na Univerzi v Ljubljani (UL) in na Univerzi v Mariboru (U M). Na U L so projekt poimenovali Digitalna UL, ${ }^{12}$ na UM pa Didakt.UM. ${ }^{13}$ Obe univerzi aktivnosti projekta nadaljujeta $v$ okviru podpornih centrov (U L prek Centra UL za uporabo IKT v pedagoškem procesu, ${ }^{14} \mathrm{U} \mathrm{M}$ pa prek Centra za podporo poučevanja $\mathrm{UM}^{15}$ ). $\mathrm{Na}$ U P pedagoško-didaktična podpora uporabnikom poteka dislocirano po posameznih članicah, ${ }^{16}$ tehnična pa je večinoma na UP FAMNIT, ki podpira informacijske rešitve na ravni UP.

\section{Vloga projekta pri izrednem poučevanju na daljavo}

Projekti uvajanja I K T v visokošolski pedagoški proces na javnih univerzah so bili vsem javnim zavodom $v$ pomoč pri premagovanju pedagoških izzivov v času epidemije. Izkušnje U P pa kažejo, da so aktivnosti projekta $\mathrm{v}$ prvem valu epidemije pri reševanju izzivov pomagale tudi učiteljem osnovnih in srednjih šol, predvsem na Obali, saj so se posamezni učitelji teh šol vključevali v številne spletne delavnice, ki smo jih organizirali v okviru projekta InoTeZ.

Kot omenjeno v uvodu, je bila U P, zaradi bližine Italije, žarišča okužb $z$ virusom SARS-COV-2, prva slovenska izobraževalna ustanova, ki je zaprla svoja vrata. Prvotno se je izvedba pedagoškega procesa v živo zadržala za 14 dni (napovedano do 20. 3. 2020), vendar je bilo kmalu jasno, da se bodo ukrepi podaljšali.

Projektna skupina InoTeZ je že pred zaprtjem univerze izvedla nekaj

\footnotetext{
${ }^{11}$ Glej https://odprtaup.upr.si/course/view.php?id=75.

${ }^{12}$ Glej https://di.uni-lj.si/.

${ }^{13}$ Glej https://didakt.um.si/Strani/Vstopna.aspx.

${ }^{14}$ Glej https://digitalna.uni-lj.si/.

${ }^{15}$ Glej https://didakt.um.si/center-za-podporo-poucevanju/predstavitev/Strani/default .aspx.

${ }^{16}$ Glej https://odprtaup.upr.si/course/view.php?id=7o\&section=1\&singlesec=1.
} 
delavnic. Od leta 2012 se namreč v prvem tednu marca izvaja t. i. Teden odprtega izobraževanja (Open Education Week - o E W) ${ }^{17}$ ki služi ozaveščanju o pomenu odpiranja izobraževanja in promociji dosežkov na tem področju. U P se prek projekta InoTeZ, kot edina slovenska institucija, v Teden odprtega izobraževanja vključuje od leta 2018. Leta 2018 in 2019 smo v tem tednu izvedli konferenco Lastovke U P, prek katere so učitelji širili primere dobre rabe IKT v izobraževanju. Leta 2020 pa smo v okviru dogodka izvedli štiri spletne delavnice. ${ }^{18}$

Delavnice so predstavljale uvod v številne druge delavnice, ki jih je projektna skupina InoTeZ začela izvajati takoj po zaprtju univerze. Kljub krajši zapori univerze smo zaznali potrebo, da učitelje seznanimo z možnostjo uporabe IK T. Delavnice so se izvajale ob različnih dnevih in urah, število udeležencev pa je preseglo vsa pričakovanja. Samo marca 2020 se jih je udeležilo 349 visokošolskih učiteljev U P. Številne delavnice so se posnele, posnetki pa so bili na razpolago za ponovne oglede, in to ne samo učiteljem U P, temveč celotni učiteljski skupnosti. Videoposnetek »Osnovno urejanja Moodle e-učilnice« ima, kljub skriti povezavi (povezava je vidna le prek portala Odprta UP), 597 ogledov, videoposnetek »Kako uporabljamo zo oM? « pa 1.352 ogledov. ${ }^{19}$

Najhitreje se je na zaprtje univerze odzvala UP FM, ki je, glede na svojo dosedanjo rabo I K T v pedagoškem procesu, imela veliko izkušenj. Učitelji U P F M so svoja predavanja, prek Arnes voX-a, prenesli na splet ne glede na kratkoročno napoved zaprtja univerze že prvi dan po zaprtju. Smo pa že sredi tedna opazili, da prihaja do težav pri uporabi videokonferenčnega sistema in občasnih težav pri prijavi uporabnikov. Glede na to, da se je pričakovalo zapiranje šol po celotni izobraževalni vertikali, smo v razširjeni projektni skupini InoTeZ začeli raziskovati druge tehnologije. Raziskovanje je bilo povezano tudi z manjkajočimi usmeritvami na ravni U P. Tako smo v okviru projektne skupine InoTeZ, sočasno s testiranjem različnih tehnologij, pripravljali smernice za izvedbo pedagoškega dela na daljavo. Pri tem so bile uporabne izkušnje U P F M, ki je pedagoško delo na takšen način že izvajala.

Priporočila za delo na daljavo v izrednih razmerah ${ }^{20}$ so podprla:

\footnotetext{
${ }^{17}$ Glej https://www.openeducationweek.org/page/what-is-open-education-week.

${ }^{18}$ Iskanje po kriteriju leto = 2020, jezik = slovenščina: https://www.openeducationweek .org/events.

${ }^{19} \mathrm{Na}$ dan 10. maja 2021.

${ }^{20}$ Glej https://odprtaup.upr.si/mod/book/view.php?id=882.
} 
- komunikacijo s študenti,

- posredovanje znanja študentom,

- sodelovalno delo s študenti.

Priporočila smo najprej pripravili v obliki dokumenta P DF in ga kot takšnega posredovali vsem visokošolskim učiteljem ter sodelavcem na U P. Kasneje pa smo pripravili še e-obliko priporočil, ki olajša sprotno dopolnjevanje in nadgrajevanje priporočil. $\mathrm{V}$ prvotni različici ta niso vsebovala priporočil za izvedbo preverjanja in ocenjevanja znanja na daljavo, so pa slednja nastala na U P F M, ki se je, zaradi kvartarne izvedbe pedagoškega procesa na vseh študijskih programih, s težavo srečala že v drugi polovici aprila 2020. Če se je U P F M na epidemijo in zaprtje univerze na osnovi predhodnih izkušenj z e-izobraževanjem in dolgoletno prakso ter podporo na fakulteti odzvala brez težav, pa bi ostale članice U P takšen prehod na splet brez aktivnosti in pomoči posameznih članov projekta InoTeZ izvedle veliko težje. Projekt InoTeZ je pri spopadu z epidemijo nedvomno odigral ključno vlogo na U P. Njegov pomen je razviden tudi iz raziskave, ki smo jo opravili na začetku izvajanja projekta, potek in rezultate pa prikazujemo v nadaljevanju.

\subsection{Razumevanje in odnos do e-izobraževanja na U P}

\section{Namen in cilji raziskave ter raziskovalni vprašanji}

Članice U P izvajajo študijsko dejavnost na različnih študijskih področjih. Razlike v študijskih področjih, kot tudi razlike v razvoju članic, so vidne tudi pri uvajanju I K T v pedagoški proces. Medtem ko so nekatere fakultete do uvajanja I K T v pedagoško prakso precej zadržane, druge veliko odločnejše in tehnološke novosti, pa tudi sodobne metode poučevanja, uvajajo brez težav. Izgovor za zadržanost članice iščejo v neprimernosti študijskega področja, čeprav posamezni navdušenci za vključevanje I K $\mathrm{T}$ v poučevanje in učenje $\mathrm{z}$ istih članic dokazujejo ravno nasprotno.

I K T se je, tako kot v podjetjih, najprej uvajala za podporo administrativnih procesov, šele kasneje pa so jo začeli vključevati v pedagoški proces (Keengwe, Kidd in Kyei-Blankson 2009). Projekti vključevanja I K T brez aktivne podpore vodstva podjetja so neuspešni, zato je vključenost slednjega $\mathrm{v}$ procese informatizacije nujna (Laudon in Laudon 2018). Izobraževalni zavodi niso izjema. Informatizacija pedagoškega procesa zahteva aktivno podporo vodstva. Tako smo v okviru projekta InoTeZ, poleg popisa infrastrukture ter anketiranja študentov in učite- 
ljev o uporabi I K T, izvedli še kvalitativno raziskavo o odnosu vodstvenih struktur do uvajanja I K T v pedagoški proces. Raziskava je potekala s pomočjo intervjujev, s katerimi smo želeli dobiti odgovore na naslednji dve raziskovalni vprašanji:

1. Kakšno je razumevanje in odnos do vključevanja ter vključenost I K T v pedagoškem procesu na članici?

2. Kakšno je razumevanje in odnos do odpiranja visokošolskega izobraževanja na članici?

\section{Potek raziskave in obdelava podatkov}

Intervjuje smo izvedli 31. januarja 2018. Razgovor je potekal v dveh ločenih skupinah - najprej v skupini prodekanov za izobraževalno oziroma študijsko dejavnost na članici, nato pa še s predstavniki članic za področje kakovosti.

Intervju s prodekani za izobraževalno/študijsko dejavnost je potekal v okviru seje univerzitetne komisije za študijske zadeve. Na seji so sodelovali štirje prodekani s šestih pedagoških članic. Prisotna je bila tudi takratna prorektorica za študijske zadeve U P ter izvajalka intervjujev, ki pozna razmere na eni od članic $z$ manjkajočim prodekanom. $V$ drugi skupini intervjuvancev je sodelovalo pet predstavnikov članic, ki so aktivni na področju kakovosti. Pri obeh intervjujih smo izhajali iz enakega nabora vprašanj:

1. Razumevanje e-izobraževanja na članici in kako oziroma zakaj se e-izobraževanje vključuje v pedagoški proces?

2. Kako je e-izobraževanje vključeno v normativne akte članice (pravila, navodila, pravilniki) ter učne načrte? Kako se vrednoti delo učiteljev, ki predmete izvajajo na e-način?

3. Kdo skrbi za tehnično in pedagoško-didaktično podporo učiteljem ter tehnično podporo študentom? Kako je poskrbljeno za usposabljanje učiteljev?

4. Kako si članica predstavlja podporo in usposabljanje v prihodnje centralizirano na U P ali po članicah? Kakšna so pričakovanja glede oblike in načina podpore?

5. Kakšno je stališče članice glede odpiranja izobraževanja? Ali bi bila članica pripravljena ponuditi del vsebin? Pod kakšnimi pogoji? Kje članice vidijo priložnosti/ovire odpiranja?

Vnaprej pripravljena vprašanja so bila osnova za vodenje razgovora, niso pa nas omejevala pri izvedbi razgovora. Tako npr. predstavnikom 
na področju kakovosti nismo ponavljali vprašanja urejenosti podpore e-izobraževanja na članici, če je prodekan članice na to vprašanje že odgovoril, smo pa to vprašanje zastavili predstavniku članice, katere prodekan je bil odsoten.

Skupinski intervju je potekal po enotnem protokolu - izvajalka intervjuja je postavila vprašanje, nakar so intervjuvanci odgovarjali v vedno istem zaporedju. Posamezniki so svoje odgovore, glede na potek razgovora, lahko vmes tudi dopolnili. Vsak razgovor je trajal 90 minut. $S$ soglasjem intervjuvancev smo oba intervjuja posneli. Prepis zvočnega zapisa razgovorov smo obdelali v pisarniškem paketu MS Office 2016. $S$ pomočjo komentarjev v besedilnem dokumentu smo označili dele besedila, ki so bili povezani $z$ vprašanjem. Komentar je vseboval kratico članice U P in kodo, ki je opredeljevala vsebino/povzetek besedila. S pomočjo makroukaza ${ }^{21}$ smo komentarje in označeno besedilo prenesli $\mathrm{v}$ nov besedilni dokument, tabelarično urejene komentarje pa še v Excel, kjer smo zapise razvrstili, podvojene zapise združili in s pomočjo kodiranja zapise razvrstili v kategorije, vezane na vsebino vprašanj:

- razumevanje e-izobraževanja (koda: pojem),

- naklonjenost vodstva (koda: vodstvo),

- vključevanje IK T v pedagoški proces (koda: vključenost),

- obstoječa podpora in usposabljanje učiteljev (koda: podpora),

- podpora in usposabljanje učiteljev na U P (koda: center),

- odpiranje izobraževanja (koda: odprto).

Pri analizi zvočnega prepisa sta se pojavili dve novi kategoriji, smiselni za vključitev v nadaljnjo obdelavo, saj naslavljata raziskovalno vprašanje o vključevanju oziroma nevključevanju I K T v pedagoški proces:

- ovire za večjo uporabo I T v vedagoškem procesu (koda: ovire),

- predlogi za izboljšave (koda: predlogi).

Urejene zapise smo dodatno uredili na način, da smo kodo ločili od imena članice. Takšen pristop nam omogoča obdelavo podatkov zbirno po kategorijah na ravni celotne univerze, ne le po posamezni članici.

\footnotetext{
${ }^{21}$ Glej https://www.thedoctools.com/word-macros-tips/word-macros/extract -comments-to-new-document/.
} 
Preglednica 3.1 Razumevanje e-izobraževanja in naklonjenost vodstva

\begin{tabular}{|c|c|}
\hline Kategorija/koda & Vsebina \\
\hline $\begin{array}{l}\text { Razumevanje } \\
\text { e-izobraževanja } \\
\text { (pojem) }\end{array}$ & $\begin{array}{l}\text { - Na članici ni enotnega razumevanja } \\
\text { - Razumevanje prepuščeno posameznemu učitelji } \\
\text { - Predavanja na daljavo, čeprav je za druge to že vključevanje } \\
\text { I K T v klasični učilnici (ponazoritev vsebin) } \\
\text { - Izvedba predmeta v virtualnem okolju } \\
\text { - Uporaba večpredstavnih vsebin } \\
\text { - Nalaganje gradiv ni e-izobraževanje } \\
\text { - I K T-orodje za izboljšanje poučevanja }\end{array}$ \\
\hline $\begin{array}{l}\text { Naklonjenost } \\
\text { vodstva } \\
\text { (vodstvo) }\end{array}$ & $\begin{array}{l}\text { - Različna podpora s strani vodstva, pogosto povezana z vsebi- } \\
\text { nami predmeta, ki jih poučujejo, in osebno izkušnjo } \\
\text { - (Presenetljiva) naklonjenost F HŠ }\end{array}$ \\
\hline
\end{tabular}

\section{Predstavitev rezultatov raziskave}

Analizo odgovorov prikazujemo po posameznih kategorijah, predstavljenih v prejšnjem podpoglavju. Kot smo predvidevali, na U P ni enotnega razumevanja e-izobraževanja (preglednica 3.1). Nekateri z eizobraževanjem razumejo izvedbo predmeta na daljavo, medtem ko je za druge e-izobraževanje uporaba I K T pri klasičnem pouku - za ponazoritev učne snovi ali za popestritev učne ure. Zanimivo je, da do razlik v razumevanju prihaja tudi znotraj fakultete. Različno razumevanje sicer ne sme biti ovira za nadaljnje aktivnosti na področju e-izobraževanja na članici in na univerzi. Smo pa v projektu te razlike upoštevali pri pripravi minimalnih standardov e-izobraževanja.

Začetniki uvajanja IK T v pedagoškem procesu so učitelji U P F M, ki so $\mathrm{z}$ vključevanjem IK T $\mathrm{v}$ pedagoški proces prišli najdlje pa tudi začeli so pred drugimi članicami. Intenzivno se IK T vključuje tudi na U P F T Š Turistici, saj prek izvedbe predmeta poteka sodelovanje učiteljev in študentov UP F T Š Turistice $z$ učitelji in študenti v Z D A. Takšno sodelovanje je možno le s podporo I K $\mathrm{T}-\mathrm{z}$ videokonferenčnim sinhronim sodelovanjem ter asinhrono komunikacijo v spletnem učnem okolju. $V$ intervjujih se je pokazala naklonjenost vodstva U P F H š, pa čeprav je bilo na UP prisotno mnenje, da se na tej članici uporabi I K T izogibajo. Res pa je, da je vključevanje IKT vezano le na dve študijski področji - geografijo in jezike.

Po mnenju intervjuvancev vsa predmetna področja niso enako primerna za intenzivno uporabo I K T. Kot bomo videli v nadaljevanju, se predmetne posebnosti kažejo tudi pri predlogih za podporo in usposabljanje, saj naj bi bila slednja prilagojena predmetnospecifičnim zahte- 
vam in potrebam. Izražena naklonjenost vodstva je odvisna od osebne izkušnje intervjuvanca.

$\mathrm{Na}$ vseh fakultetah se uporablja odprtokodni sistem za podporo in upravljanje učenja (Learning Management System - LMS) Moodle. ${ }^{22}$ Za Moodle, ki se na UP imenuje e-učilnica, skrbi UP FAMNIT. UP FAM N I T (tehnična podpora) večinoma izvede le namestitev Moodla, medtem ko je uporabniški administrativni del preložen na posamezno članico. Na članici za administriranje e-učilnice skrbi informatik ali visokošolski učitelj, navdušen uporabnik Moodla. UP FAMNIT skrbi tudi za posodobitev sistema in izdelavo zaščitne kopijo baze podatkov. Skrb za e-učilnico ni sistemsko urejena. Vsebinske podpore na fakultetah večinoma ni. Pomoč in usposabljanje večinoma poteka po kolegialni liniji; veliko je t.i. svetovanja $1: 1$, kjer učitelj z izkušnjami pomaga kolegu začetniku.

E-učilnica se na fakultetah uporablja različno intenzivno. Čeprav se na nekaterih fakultetah e-učilnico odpre za vse predmete, nadzora nad uporabo večinoma ni. Zato med intervjuvanci obstaja bojazen, da se eučilnica lahko uporablja kot način prikrivanja manjše aktivnosti učitelja. Uporaba e-učilnice je večinoma prepuščena posameznemu učitelju, razen na U P F M, kjer je del predmetov visokošolskega strokovnega programa potrebno izvesti v spletnem učnem okolju. ${ }^{23}$ Učitelji na U P F M morajo izvedbo predmeta v spletnem učnem okolju (e-učilnici ali drugih okoljih) zapisati v načrtu izvedbe predmeta. Spremljanje realizacije izvedbe zaenkrat še ni urejeno. Intervjuvanci se strinjajo, da bi morali izvedbo predmetov na podoben način urediti tudi na drugih članicah, vendar mogoče nekoliko manj formalizirano in podrobno, kot je to urejeno na U P F M. Pri uporabi e-učilnice je opaziti vpliv tečajev M O o c, saj učitelji, ki so se teh tečajev udeležili, svoje predmete pogosto uredijo na podoben način - s terminsko ali tematsko razporeditvijo snovi in sprotnim delom študentov.

Učitelji na fakultetah uporabljajo tudi drugo I K T, predvsem oblačne storitve, kot so npr. Googlovi dokumenti. Pametne ali interaktivne table so v uporabi na treh fakultetah, njihova uporaba pa je odvisna od posameznega učitelja in študijskega področja. Vse prepogosto se inte-

${ }^{22}$ Glej https://moodle.org/.

${ }^{23}$ Obveza je veljala za študijsko leto $2017 / 2018$, ko so učitelji na U P F M zaradi finančnih razlogov del kontaktnih ur izvedli prek t.i. drugih oblik študija (D oš), poimenovanih kar e-D oš, saj se to delo izvajalo v spletnih učnih okoljih. 
Preglednica 3.2 Vključenost I K T v pedagoški proces in obstoječa podpora na fakulteti

\begin{tabular}{|c|c|}
\hline Kategorija/koda & Vsebina razgovora \\
\hline $\begin{array}{l}\text { Vključevanje I K T } \\
\text { v pedagoški pro- } \\
\text { ces (vključenost) }\end{array}$ & $\begin{array}{l}\text { - Uporaba e-učilnic (Moodle): (a) podpora v času odsotnosti uči- } \\
\text { telja, (b) neobvezno dopolnilo klasične izvedbe - način upo- } \\
\text { rabe prepuščen učitelju, (c) obvezno dopolnilo - študentje } \\
\text { opravijo del študijskih obveznosti na daljavo } \\
\text { - Intenzivnost vključevanja je odvisna od učitelja (osebna naklo- } \\
\text { njenost in/ali vsebine predmeta) ali katedre (npr. geografi na } \\
\text { F H š) } \\
\text { - E-učilnice se uporabljajo različno intenzivno - od osnovnih do } \\
\text { naprednih funkcij; odvisno od članice in posameznega učitelja } \\
\text { - I K T za ponazoritev snovi, iskanje informacij } \\
\text { - Uporaba tudi drugih tehnologij (Google Drive, interaktivna ta- } \\
\text { bla na P E F) } \\
\text { - Različen pristop pri odpiranju predmetov in vzpodbujanje uči- } \\
\text { teljev k uporabi } \\
\text { - Različna vključitev e-načina v učne načrte in različno vredno- } \\
\text { tenje učiteljevega dela } \\
\text { - Učitelji na F M način vključevanja e-učilnice opredelijo v načrtu } \\
\text { izvedbe, drugi ne; na enih članicah je določen minimum vsebin } \\
\text { (informacij) in aktivnosti (npr. forum), ki morajo biti vklju- } \\
\text { čene v e-učilnico, na drugih sta uporaba in način uporabe pre- } \\
\text { puščena učitelju - predlog: srednja pot; struktura v e-učilnici } \\
\text { naj bi sledila praksi tečajev Mo oc (teme, termini) } \\
\text { - Uporaba e-učilnice ni posebej spremljana (nadzorovana) - } \\
\text { skrb, da se uporablja za prikrivanje neaktivnosti učitelja } \\
\text { - F M izvaja posamezne predmete online } \\
\text { - Na F M je del predmeta na visokošolskem strokovnem pro- } \\
\text { gramu obvezno izvesti na e-način } \\
\text { - F Tš sodeluje z ameriško univerzo, skupna online predavanja } \\
\text { pri enem predmetu }\end{array}$ \\
\hline $\begin{array}{l}\text { Obstoječa pod- } \\
\text { pora in usposab- } \\
\text { ljanje učiteljev } \\
\text { (podpora) }\end{array}$ & $\begin{array}{l}\text { - Večinoma tehnična podpora informatika ali navdušenega upo- } \\
\text { rabnika IKT (učitelja)/kolega na fakulteti } \\
\text { - Vsebinska podpora je redka } \\
\text { - Usposabljanje po potrebi (nimajo vsi enakih potreb), prilago- } \\
\text { jena usposabljanja } \\
\text { - Pri uporabi IK T svetovanja } 1: 1\end{array}$ \\
\hline
\end{tabular}

raktivna tabla uporablja le za predstavitev snovi, manj pa za interakcijo z učnimi gradivi, kar je ena od njenih osnovnih zmožnosti.

Pri uporabi e-učilnice je bila izpostavljena potencialna ovira za večjo vključenosti I K T v pedagoški proces, saj je delo učitelja pri e-načinu izvedbe vrednoteno manj kot delo učitelja v klasičnem razredu oziroma je vrednoteno, kot so vrednotene vaje. Na U P F M se tako delo na da- 
ljavo oziroma delo v e-učilnici vrednoti kot druge oblike študija (D O š), medtem ko se delo na ostalih fakultetah vrednoti, kot se vrednoti način dela, ki ga e-učilnica nadomešča. E-predavanje se tako vrednoti kot klasično izvedeno predavanje, e-izvedba vaj pa kot klasično izvedene vaje. Vrednotenje dela učiteljev bo pri uporabi I K T nedvomno moralo biti poenoteno in urejeno na način, da ne bo zaviralo uvajanja I K T v pedagoški proces. Zbrani komentarji o vključevanju I K T v pedagoški proces in obstoječi podpori na članici so razvidni iz preglednice 3.2.

Poleg omenjenega vrednotenja dela učiteljev so intervjuvanci izpostavili še druge ovire (preglednica 3.3), ki otežujejo intenzivnejše vključevanje IKT $\mathrm{V}$ pedagoški proces. Izpostavljena je bila obremenjenost učiteljev z drugim delom, zaradi česar se težko udeležijo usposabljanj ali delavnic, na katerih bi spoznali možnosti in priložnosti vključevanja sodobnih tehnologij v pedagoški proces ter z I K T podprtega načina dela. Če je na nekaterih fakultetah izpostavljeno, da si starejši učitelji ne želijo sprememb, pa tega na drugih fakultetah ne opažajo: IKT uvajajo tako mlajši kot starejši učitelji. Je pa res, da je nekatere učitelje težko prepričati v spremembo, če so naklonjeni klasičnim oblikam dela ter nenaklonjeni I K T. Izpostavljeno je bilo, da bi bilo koristno predstaviti primere dobre rabe in tako učiteljem $\mathrm{z}$ različnih študijskih področij prikazati prednosti in koristi uporabe I K T v pedagoškem procesu. Širjenju primerov dobre rabe smo v projektu InoTeZ namenili še posebno pozornost. Poleg promocije rabe I K T po posameznih članicah, ki je potekala prek članov projektne skupine, je projektna skupina organizirala konference Lastovke UP, ${ }^{24}$ katerih osnovni namen je bil ravno prikaz primerov dobre rabe in motiviranje učiteljev za spreminjanje pedagoške paradigme poučevanja in učenja.

Intervjuvanci so kot oviro za uporabo I K T v pedagoškem procesu izpostavili zastarelo opremo pa tudi skrb, da bi I K T nadomestila učitelja. Na U P PEF opozarjajo na previdnost pri uporabi IKT - ta naj bi bila osmišljena in premišljena.

Intervjuvanci so podprli v projektu načrtovano enotno tehnično in vsebinsko podporo na ravni U P (preglednica 3.4). Pri tem izpostavljajo potrebo po t. i. infrastrukturnem značaju organizacijske enote (centra), ki bi se financirala na ravni UP, posamezne storitve pa bi se uporabnikom (fakultetam) ne zaračunavale posebej. Zaračunavanje storitev na na ravni U P bi članice vodilo $k$ neuporabi teh storitev. Kljub centralizi-

${ }^{24}$ Glej https://odprtaup.upr.si/course/view.php?id=75. 
Preglednica 3.3 Ovire za uporabo IK T v pedagoškem procesu

\begin{tabular}{|c|c|}
\hline Kategorija/koda & Vsebina razgovora \\
\hline $\begin{array}{l}\text { Ovire za večjo } \\
\text { uporabo I KT } \\
\text { v pedagoškem } \\
\text { procesu (ovire) }\end{array}$ & $\begin{array}{l}\text { - Obremenjenost učiteljev z drugim delom, kar onemogoča ra- } \\
\text { zvoj novih načinov poučevanja } \\
\text { - Neprimernost študijskega področja (vsebin) ali načina izvaja- } \\
\text { nja predmeta (npr. nujnost izvedbe vaj v živo) } \\
\text { - Učitelji naklonjeni klasičnim tehnikam/oblikam poučevanja; } \\
\text { nekateri učitelji težko sprejmejo novosti oziroma trmasto } \\
\text { vztrajajo pri klasičnem načinu dela } \\
\text { - Učitelji niso posebej motivirani za vključevanje I K T } \\
\text { - Na enih članicah je starost učiteljev ovira, na drugih ne } \\
\text { - Vrednotenje dela učiteljev za pripravo predmetov v e-učilnici } \\
\text { - Skrb, da bi I K T nadomestila učitelja } \\
\text { - Previdnost pri uporabi I KT } \\
\text { - Slaba oprema na članici in na U P } \\
\text { - Študentje želijo osebni stik }\end{array}$ \\
\hline
\end{tabular}

rani podpori na ravni UP pa si intervjuvanci želijo del podpore ohraniti na članici, saj bi bila takšna podpora bolj prilagojena potrebam članice in posameznemu uporabniku na članici, bila pa bi tudi hitrejša. Med razgovorom $z$ obema skupinama deležnikov je bila na več mestih poudarjena raznolikost študijskih področij, kar bi se moralo upoštevati tudi pri podpori in usposabljanjih. Po zaključku projekta se zaradi pomanjkanja finančnih sredstev podpora pri uporabi I K T vrši po posameznih članicah. Vse informacije kot tudi gradiva so dostopni na portalu Odprta UP, ${ }^{25}$ ki naj bi tudi v prihodnje ostal stičǐšče odprtega izobraževanja.

Pogled na odprto izobraževanje smo želeli preveriti tudi v intervjujih. Pokazalo se je, da odprto izobraževanje, tako kot e-izobraževanje, razume vsak po svoje. Učitelji U P so na načelni ravni sicer naklonjeni odpiranju, vendar so izpostavili vrsto težav - varovanje avtorskih pravic, manjkajoči viri za razvoj odprtih vsebin (obremenjenost učiteljev, vprašanje financiranja razvoja odprtih vsebin), podpora v času izvedbe teh vsebin itn. Vidijo pa v odprtih vsebinah možnost promocije študijskih programov fakultet kot tudi priložnost za promocijo posameznih izvajalcev (učiteljev). Odpiranje posameznih fakultet bi se lahko razvilo prek t.i. notranje mobilnosti, pri kateri pa se žal trči ob številne ovire. Intervjuvanci so izpostavili predvsem neustrezno obračunavanje izmenjav študentov (plačilo za kreditno točko).

${ }^{25}$ Glej https://odprtaup.upr.si/. 
Preglednica 3.4 Podpora na ravni UP in odpiranje U P

\begin{tabular}{|c|c|}
\hline Kategorija/koda & Vsebina razgovora \\
\hline $\begin{array}{l}\text { Podpora in } \\
\text { usposabljanje na } \\
\text { nivoju U P (cen- } \\
\text { ter) }\end{array}$ & $\begin{array}{l}\text { - Podprejo vse članice } \\
\text { - Enotne storitve za vse članice } \\
\text { - Infrastrukturni center, financiran s strani u P, brez medseboj- } \\
\text { nega zaračunavanja ali obračunavanja storitev } \\
\text { - Del podpore tudi na članice } \\
\text { - Vrednotenje dela učiteljev, ki bi delovali v centru; potrebna je } \\
\text { pedagoško-didaktična podpora, ki mora biti ustrezno vredno- } \\
\text { tena; te podpore ne more opravljati strokovni delavec } \\
\text { - Vnaprej napovedana usposabljanja, ko ni predavanj } \\
\text { - Usposabljanja prilagojena študijskim področjem } \\
\text { - Prednost svetovanju } 1: 1\end{array}$ \\
\hline $\begin{array}{l}\text { Odpiranje izo- } \\
\text { braževanja in } \\
\text { UP (odprto) }\end{array}$ & $\begin{array}{l}\text { - Notranja mobilnost način odpiranja izobraževanja posamezne } \\
\text { članice, oviri: (a) notranje zaračunavanje KT, (b) usklajevanje } \\
\text { urnikov } \\
\text { - Pripravljenost za pripravo odprtih vsebin; predavanja so že se- } \\
\text { daj javna, torej so lahko javne tudi e-vsebine - različno stališče: } \\
\text { če se predvideva aktivnost študentov, predmet ne more biti } \\
\text { ravno odprt, če so odprte le vsebine, pa je lahko } \\
\text { - Ovire za odpiranje vsebin: (a) potrebna razvojna sredstva, } \\
\text { (b) predmet bi moral imeti začetek in konec, (c) vprašanje pod- } \\
\text { pore udeležencev, (č) vrednotenje dela učitelja za pripravo vse- } \\
\text { bin in za spremljanje udeležencev, (d) opredelitev avtorskih } \\
\text { pravic } \\
\text { - Odprte vsebine priložnost za promocijo fakultete in profesor- } \\
\text { jev }\end{array}$ \\
\hline $\begin{array}{l}\text { Predlogi } \\
\text { (predlogi) }\end{array}$ & $\begin{array}{l}\text { - Ukinitev PowerPointa } \\
\text { - Učiteljem predstaviti primere dobre rabe I K T } \\
\text { - Priprava načrta izvedbe predmeta po zgledu strukture tečaja } \\
\text { MO OC } \\
\text { - Srednja pot med urejenostjo na U P F M in neurejenostjo na dru- } \\
\text { gih članicah } \\
\text { - I K T je lahko element kakovosti - preglednost; vključevanje I K T } \\
\text { v pedagoški proces vključiti v kazalnik spremljanja kakovosti } \\
\text { - Študentje se s pomočjo I K T lažje učijo, čeprav je študij še vedno } \\
\text { trdo delo študenta }\end{array}$ \\
\hline
\end{tabular}

V razgovorih so bile izpostavljene pomanjkljive digitalne in tudi študijske spretnosti študentov, zato so intervjuvanci podali predloge o pripravi učnih vsebin, ki bi zapolnile manjkajoče vrzeli, hkrati pa bi bile dostopne vsem študentom U P, ne glede na fakulteto, s katere študent prihaja. Odprte vsebine s področja rabe I K T naj bi bile prosto dostopne tudi učiteljem. 


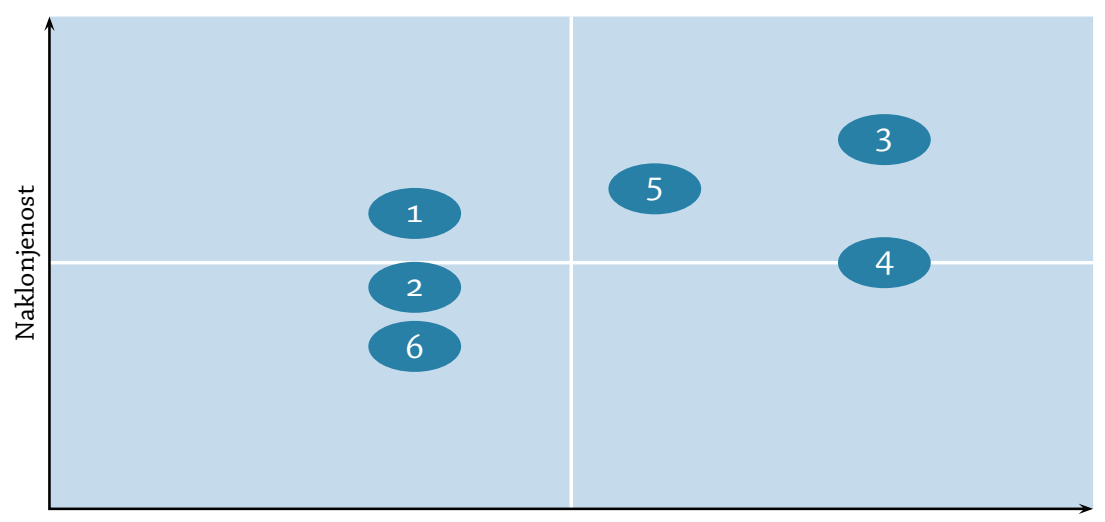

Intenzivnost rabe IK T v pedagoškem procesu

Slika 3.1 Podpora vodstva in vključenost I K T v pedagoški proces

\section{Razprava}

Cilji projekta InoTeZ so večinoma sledili razpisni dokumentaciji M Iz š. Pred začetkom projekta so bili na UP izvedeni vsaj trije poskusi za izdelavo strategije in/ali uvedbo e-študija, ki so bili zaradi pomanjkanja podpore vodstvenih struktur neuspešni. Rezultati intervjujev so pokazali, da težave, s katerimi se srečuje U P, izhajajo ne samo iz različnega razumevanja e-izobraževanja, temveč predvsem iz različnega sprejemanja I K T, odnosa do I K T na članici ter različne podpore vodstva. Zadnja je večinoma odvisna od osebnostnih lastnosti posameznikov in izkušenj, ki jih imajo z I K T in e-izobraževanjem.

$\mathrm{Na}$ osnovi razgovorov smo izoblikovali grafični prikaz (slika 3.1), ki članico umesti glede na vključenost IKT v pedagoški proces in na izraženo podporo vodstva. Zaradi zagotavljanja anonimnosti so imena posameznih fakultet izpuščena. Umestitev posamezne fakultete $\mathrm{v}$ matriko je seveda subjektivna, izhaja pa iz mnenja intervjuvancev in zato ne odraža povsem realnega stanja. Vsekakor pa nazorno predstavlja raznolikost med članicami U P, ki jo je moč opaziti tudi v praksi. V praksi se sicer pogosto opazi načelno naklonjenost uvajanju IKT, podpore pa kasneje ni.

Nekatere članice I K T vključujejo organizirano in načrtovano, pri drugih je njeno uvajanje $v$ pedagoški proces še vedno prepuščeno posameznim navdušencem. Organizacija podpornih dejavnosti na fakulteti in na univerzi se zelo razlikuje. Učitelji, ki so sodelovali v razpravah, so podprli enotno ureditev tehnične in pedagoško-didaktične podpore na univerzitetni ravni, pri čemer so izpostavili potrebo po upoštevanju po- 
treb posameznih učiteljev. Učitelji opozarjajo na potrebo po enotnem sistemu vrednotenja učiteljevega dela, ki bi ne smel ovirati intenzivnejšega vključevanja I K T v pedagoško prakso. Obstoječi sistem vrednotenja je ugodnejši za klasične oblike dela, predvsem predavanja, kot pa za izvedbo na daljavo. Slednja zahteva več predpriprav, več inovativnosti in ustvarjalnosti, da študentje pri predmetu dosežejo načrtovane učne rezultate. Vendar o tem več kasneje.

V intervjuje vključeni visokošolski učitelji, ki opravljajo tudi druge funkcije (prodekan/-ja, vodja sistema kakovosti na članici), se seveda zavedajo trendov na področju visokega šolstva v svetu in jim želijo slediti. Odpiranje izobraževanja in večja vključenost I K T v pedagoški proces bi lahko imela pozitivne učinke za univerzo, fakultete in akademsko osebje. Se pa intervjuvanci zavedajo, da IK T sama ne spreminja pedagoške paradigme in da se sprememba paradigme, skladna s sodobnimi trendi (npr. k študentu osredinjeno poučevanje), lahko zgodi le $\mathrm{z}$ aktivno podporo vodstva in tudi ob upoštevanju študentov na univerzi.

\subsection{Odziv U P na prvi val epidemije covida-19}

Zapiranje U P ter vlogo projekta InoTeZ pri zapiranju smo že predstavili. Učitelji, ki smo marca 2020 pedagoški proces izvajali na daljavo, smo o načinu izvedbe poročali $\mathrm{v}$ univerzitetnem informacijskem sistemu (U N Is). Za vsako izvedbo (predavanja, seminarji, seminarske, laboratorijske ali klinične vaje) smo za vsak predmet evidentirali:

- prostor - izbirali smo lahko med klasično učilnico (predavalnica, laboratorij ...), kombinirano izvedbo (klasična učilnica z možnostjo e-participacije študentov), e-izvedbo (izvedba kontaktnih ur na daljavo v živo) in e-učilnico;

- uporabljeni sistem - klasična učilnica, zoom, Jitsi, vox, MS Teams, Google Meet, Moodle, drugo;

- ure - vpisati smo morali število kontaktnih in število izvedenih ur;

- opis vsebine, ki je bila predstavljena prek e-izvedbe.

Vsebinsko je obrazec za vnos opravljenih obveznosti sestavljen nekoliko nespretno in pridobljeni podatki ne odražajo pogleda na vsebinski in kakovostni vidik izvedbe pedagoškega procesa, sporna pa je tudi struktura samega obrazca. Moodle (e-učilnico) lahko npr. uporabljamo tudi v klasični učilnici. Kombinirana izvedba, kot v slovenščino prevajamo blended learning, predstavlja kombinacijo srečanj $\mathrm{v}$ živo in aktivnosti študentov po spletu, na daljavo (Bates 2005, 9; Sulčič 2008, 28; 
Bregar, Zagmajster in Radovan 2020, 19). Gre torej za način izvedbe in ne za prostor. Prostor bi lahko bil klasična učilnica in splet ali pa kombinacija obojega. Če imamo v mislih kakovostno delo na daljavo, tega ni brez sodelovanja študentov, kar pomeni, da je izbira "z možnostjo eparticipacije študentov« odveč. E-izvedba pomeni izvedbo predmeta na e-način (elektronsko), kar je lahko sinhrono ali asinhrono in lahko poteka v različnih spletnih okoljih, tudi e-učilnice, kot na U P imenujemo namestitev Moodle.

Klasična učilnica se uporablja kot "uporabljen sistem « in kot prostor. ZOOM, Jitsi, ${ }^{26}$ VOX $^{27}$ in Google Meet ${ }^{28}$ so videokonferenčni sistemi in med njimi ni tolikšne razlike, da bi jih bilo potrebno razlikovati, razen če želimo na osnovi tega predvideti preferenco učiteljev in potrebo po nabavi licenc, v kolikor gre za licenčno programsko opremo. Ms Teams ${ }^{29}$ prek t. i. Ekip omogoča veliko več kot le videokonferenčni sistem. Ekipe prek svojih kanalov lahko uporabimo tudi kot alternativo Moodlu (Florjančič in Wiechetek v tisku).

$\mathrm{Na}$ osnovi zbranih podatkov smo pripravili pregled tehnologij, ki so jih učitelji uporabili za nadomeščanje kontaktnih ur v prvih štirih tednih zaprtja univerze (marec-april 2020) (preglednica 3.5). Glede na možen izbor tehnologij v U N IS-u so se učitelji najpogosteje odločali za videokonferenčne sisteme ( učitelji, zaradi dobrih izkušenj z e-izobraževanjem, uporabili predvsem e-učilnico Moodle. Prek e-učilnice so učitelji U P F M nadomestili $41 \%$ kontaktnih ur. Preseneča uporaba e-pošte na U P PE F (8\%), saj gre za tehnološko nezahteven in pedagoško manj ustrezen način posredovanja gradiv. V preglednici 3.5 prikazujemo tri najpogosteje uporabljene tehnologije po posameznih članicah UP.

Ob zaključku študijskega leta je Sektor za izobraževalno dejavnost U P objavil podatke za celotno študijsko leto. Iz njih izhaja, da je bila več kot polovica kontaktnih ur $(58,3 \%)$ vseh članic nadomeščena $\mathrm{z}$ videokonferenčnim sistemom zo oM, kar je bila tudi osnova, da je UP za študijsko leto 2020/2021 nabavila licence za vse zaposlene in študente.

\footnotetext{
${ }^{26}$ Odprtokodna rešitev, https://jitsi.org/.

${ }^{27}$ Arnes vox, https://vox.arnes.si/.

${ }^{28}$ Googlov videokonferenčni sistem. https://meet.google.com/.

${ }^{29}$ M S Teams je okolje za sodelovalno delo in del storitev 0365, za katere imajo izobraževalne ustanove v Sloveniji prek M I z š nabavljene licence, glej https://www.microsoft .com/en-ww/microsoft-teams/log-in.
} 
Preglednica 3.5 Najpogosteje uporabljene tehnologije za nadomeščanje kontaktnih ur

\begin{tabular}{|c|c|c|c|c|c|c|}
\hline Članica U P & $\mathrm{ZOOM}$ & JITS I & vox & Webex & Moodle & e-pošta \\
\hline UP FH Š & 30 & 40 & & & 18 & \\
\hline UP FM & 34 & & 13 & & 41 & \\
\hline UP FAMNIT & 62 & & 4 & & 21 & \\
\hline UP F TŠ Turistica & 70 & & 7 & & 35 & \\
\hline UP PEF & 47 & & & & 24 & 8 \\
\hline UP FVZ & 22 & 74 & & 7 & & \\
\hline
\end{tabular}

OPOMBE Vodstotkih.

Prek e-učilnice so učitelji nadomestili 13,7\% kontaktnih ur, prek Jitsija pa 12,9\%. Sledita Skype s 4,4\% in e-pošta z 2,9\%. Način nadomeščanja kontaktnih ur kaže na to, da se študij na daljavo na UP še vedno večinoma razume kot prenos vsebin klasičnih srečanj s študenti v sinhrono komunikacijo po spletu, kar pa, kot smo prikazali v uvodu, ni. Odziv U P kot celote v prvem valu epidemije še ne kaže večjega premika v smeri digitalizacije izobraževalne dejavnosti. Tako kot v podjetjih tudi $\mathrm{v}$ izobraževalnih organizacijah uvedba IK T zahteva prenovo osnovne (izobraževalne) dejavnosti.

Poseben izziv pri delu na daljavo predstavljata preverjanje in ocenjevanje znanja na daljavo, kar obravnavamo $\mathrm{v}$ enem od naslednjih poglavij. 



\section{E-izobraževanje na U P F M}

\subsection{Začetek in razvoj}

E-izobraževanje je na UP F M prisotno še iz časa Visoke šole za management (V ̌ M), ${ }^{1}$ pred že skoraj dvajsetimi leti. Začetki namreč segajo $\mathrm{v}$ študijsko leto 2002/2003 (Sulčič 2007), ko smo s spletno stranjo podprli izvedbo predmeta Digitalna ekonomija in e-poslovanje. Prek statične spletne strani smo izvajalci predmeta študentom posredovali vse informacije o predmetu, jih sproti obveščali in posredovali navodila za pripravo tedenskih nalog. Študentje so prek spletne strani imeli dostop tudi do vseh študijskih gradiv. Izvedba predmeta je sicer potekala klasično, spletno stran smo uporabili le za podporo klasične izvedbe. Komunikacija s študenti je potekala v razredu in/ali po e-pošti. Po e-pošti so študentje posredovali tudi svoje tedenske naloge. Uporaba takšne (statične) spletne strani predstavlja enosmerno komunikacijo med učitelji in študenti. Takšno enosmerno posredovanje študijskih gradiv je omogočal tudi šıs.

V študijskem letu 2003/2004 je bil na UP F M ustanovljen Center za izobraževanje (c e I), ki je na fakulteti uvedel odprtokodni sistem za upravljanje učenja (Learning Management System - L MS) Moodle ${ }^{2}$ ter poskrbel za tehnično in pedagoško-didaktično podporo uporabnikom. Odločitev za Moodle je temeljila na dostopnosti in enostavnosti uporabe, pa čeprav takratna različica $(1.4 .3)^{3}$ še ni bila prevedena v slovenščino. Odločitev za Moodle temelji na dejstvu, da ta podpira konstruktivistično teorijo učenja, ${ }^{4}$ ki smo jo na UP FM vključevali v pedagoški proces (Sulčič 2007). Moodle na U P F M že od vsega začetka imenujemo

\footnotetext{
${ }^{1}$ Visoka šola za management se je v Fakulteto za management preoblikovala leta 2003, istega leta pa se je združila s takrat nastalo Univerzo na Primorskem, zato sedaj govorimo o Univerzi na Primorskem, Fakulteti za management, ali okrajšano U P F M.

${ }^{2}$ Glej https://moodle.org/.

${ }^{3}$ Prva različica Moodla je bila izdana leta 2002 (https://moodle.com/about/), kar pomeni, da se je Moodle na U P F M začel uporabljati že leto po njegovi prvi izdaji.

${ }^{4}$ Glej https://docs.moodle.org/310/en/Philosophy.
} 
"e-učilnica«. ${ }^{5} \mathrm{Z}$ vzpostavitvijo e-učilnice smo tudi onemogočili posredovanje gradiv študentom po Š I S-u, saj je takšen pristop povzročal precej zmede: učitelji namreč starih gradiv niso brisali, študentje pa niso vedeli, ali so naložena gradiva tista, ki jih morajo naštudirati za izpit.

Center za e-izobraževanje (CeI) je pripravil prva navodila za Moodle v slovenskem jeziku in jih delil z ostalimi uporabniki Moodla v Sloveniji. V letu 2007 je U P F M prek CeI vzpostavil skupnost slovenskih uporabnikov Moodla in jo poimenoval moodle.si. Po zgledu uporabnikov Moodla v tujini smo tudi v Sloveniji organizirali t. i. konference MoodleMoot. UP F M je prvi slovenski MoodleMoot organiziral in izvedel leta 2007. ${ }^{6}$ Sledile so še tri zaporedne konference. CeI je od začetka svojega delovanja skrbel tudi za usposabljanje uporabnikov Moodla, tako na fakulteti kot tudi širše, doma in v tujini.

V študijskem letu 2007/2008 smo z e-učilnico podprli izvedbo vseh predmetov na UP F M. Center za e-izobraževanje je pripravil osnovno predlogo predmeta, ki je predvidela minimalni obseg vsebin in podpore. Učitelj je študentom prek e-učilnice posredoval učni načrt in študijska gradiva, podpora pa je potekala prek foruma »Vprašajte učitelja« (poleg foruma obvestil). Učitelji so obseg in način dela v e-učilnici iz leta v leto poljubno dopolnjevali in nadgrajevali. Tako so prek e-učilnice podpirali diskusije študentov, študentje so tam oddajali naloge in opravljali teste znanja. Izvajalo se tudi medvrstniško ocenjevanje znanja (Moodlova aktivnost Delavnica). Prek e-učilnice so se na daljavo izvajali tudi posamezni predmeti s področja poslovne informatike (npr. predmeti E-izobraževanje, Management e-izobraževanja in Izzivi informacijske družbe).

Leta 2012 so se na U P F M ukinili vsi centri, tudi Center za e-izobraževanje. Podporo uporabnikom je od študijskega leta 2003/2004 nudila vodja centra, avtorica pričujoče monografije, ki je podporne dejavnosti oblikovala pod nazivom »Podpora e-izobraževanja«. Za stik uporabnikov s podporo se je ohranil e-poštni naslov centra (cei@fm-kp.si).

Vse te izkušnje so učiteljem UP FM koristile ob uvedbi t.i. drugih oblik študija (D O Š), ki jih je U P F M uvedla zaradi finančnih težav (Florjančič idr. 2019). S pomočjo D oš so učitelji nadomeščali posamezne ure

\footnotetext{
${ }^{5}$ Pojem e-učilnica, kar je okrajšava za elektronsko učilnico, smo po vzoru e-poslovanja oziroma e-izobraževanja uporabili prvi v Sloveniji in tako ta pojem zasidrali v slovenskem izobraževalnem prostoru.

${ }^{6}$ Glej https://www.moodle.si/moodle/mod/page/view.php?id=407.
} 
Preglednica 4.1 Vpisani študentje v 1. letnik po študijskih programih U P F M

\begin{tabular}{lrr}
\hline Študijski program & 2019/2020 & 2020/2021 \\
\hline Dodiplomski študijski programi & 169 & 167 \\
Visokošolski strokovni program Management & 104 & 98 \\
Univerzitetni študijski program Management (S L O) & 41 & 32 \\
Univerzitetni študijski program Management (ANG) & 24 & 37 \\
\hline Podiplomski magistrski študijski programi & 52 & 95 \\
Management (s LO in ANG) & 27 & 50 \\
Ekonomija in finance (S LO in ANG) & 9 & 11 \\
Management trajnostnega razvoja & 6 & 16 \\
Pravo za management & 10 & 18 \\
\hline Doktorski študijski program Management & 8 & 10 \\
\hline
\end{tabular}

klasično izvedenih vaj. Glede na to, da so se te ure večinoma izvajale prek e-učilnice pa tudi drugih spletnih okolij, smo jih poimenovali kar e D O š. S študijskim letom 2017/2018 so ure e D Oš postale obvezni del visokošolskega študijskega programa Management. Odločitev za vključitev ur v druge študijske programe (dodiplomski univerzitetni program in magistrske študijske programe) pa je bila prepuščena odločitvi učitelja. S študijskim letom 2018/2019 ure e D Oš niso bile več obvezne, jih je pa velika večina učiteljev, zaradi dobrih izkušenj in vloženega dela v njihovo pripravo, ohranila.

\subsection{Izvedba pedagoškega procesa pred epidemijo}

U P F M izvaja študijske programe na vseh treh bolonjskih stopnjah. Pregled študijskih programov in števila vpisanih študentov $\mathrm{v}$ študijskih letih 2019/2020 in 2020/2021 prikazujemo v preglednici 4.1.

Izvedba vseh predmetov na U P F M je že od leta 2007/2008 podprta z e-učilnico. Na začetku smo zaradi velikega števila študentov vsako študijsko leto odprli novo e-učilnico, kar je pomenilo novo namestitev Moodla. E-učilnice so se med seboj razlikovale po letnici; tako je bila npr. namestitev Moodla na domeni eucilnica.si/2016/ namenjena podpori izvedbe predmetov v študijskem letu 2016/2017, eucilnica.si/2017/ pa podpori izvedbe v študijskem letu 2017/208. Učiteljem, ki so imeli bogato urejene e-učilnice, smo te učilnice na njihovo zahtevo prenašali iz leta $v$ leto, sami pa so jih po potrebi dopolnjevali in posodabljali. Seveda so svoje e-učilnice nastavljali tudi s čisto predlogo in vsebine nastavljali na novo, kar smo jim po nekajkratnih prenosih tudi svetovali. Od študijskega leta 2018/2019 smo predmete predhodnega leta premaknili v 
Preglednica 4.2 Študentje U P F M po študijskih letih

\begin{tabular}{lrrrr}
\hline Stopnja & $2017 / 2018$ & $2018 / 2019$ & $2019 / 2020$ & $2020 / 2021$ \\
\hline Dodiplomski študij (B 1) & 587 & 487 & 475 & 542 \\
Magistrski študij & 237 & 202 & 155 & 232 \\
Doktorski študij & 29 & 27 & 28 & 41 \\
\hline Skupaj & 853 & 716 & 658 & 815 \\
\hline
\end{tabular}

OP Омве Po podatkih UP FM, glej https://www.fm-kp.si/predstavitev/skrb_za _kakovost,

Slika $4 \cdot 1$

Struktura e-učilnice za študijsko leto 2020/2021

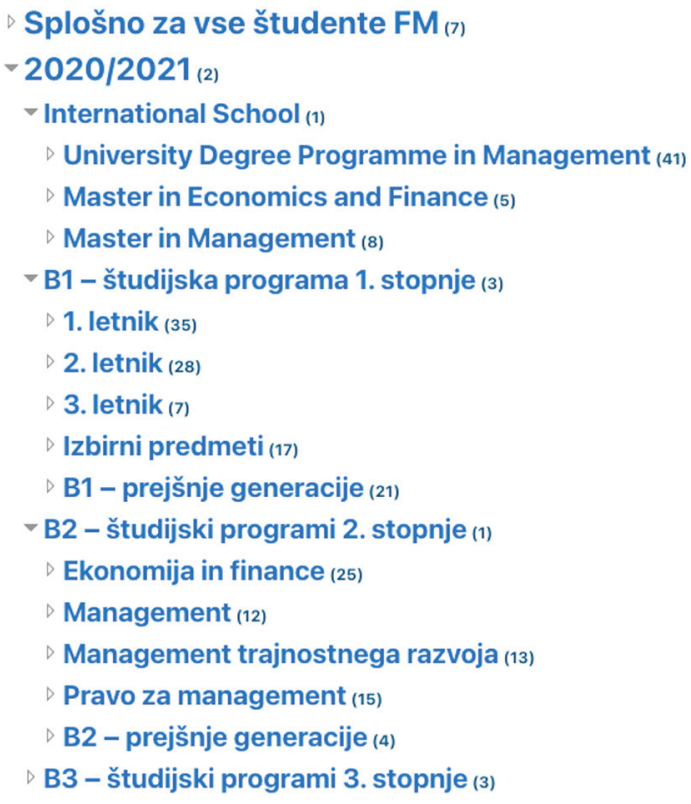

arhivsko kategorijo, za novo študijsko leto pa smo jih odprli v kategoriji 2018/2019. Takšen pristop uporabljamo tudi za vsa nadaljnja študijska leta, saj se je število vpisanih študentov zmanjševalo (preglednica 4.2). Kljub povečanju študentov v študijskem letu 2020/2021 bomo sistem odpiranja e-učilnice ohranili. Vsako študijsko leto se odpre nova kategorija (poimenovana s študijskim letom), znotraj nje pa so predmeti razvrščeni kot prej - po študijskih programih in letnikih (slika 4.1).

Novo študijsko leto na osnovi načrta izvedbe za prihodnje študijsko leto, kar je potrjeno na senatu U P F M, odpiramo že pred odhodom na letni dopust oziroma najkasneje do 15. avgusta vsakega leta. V vsak predmet vnesemo predvidenega nosilca predmeta, ki lahko takoj prične $\mathrm{z}$ urejanjem predmeta ali pa Podpori e-izobraževanja (v nadaljevanju pod- 
pora) naroči prenos vsebine predhodnih izvedb. Nekateri učitelji so na osnovi pripravljenih navodil uvoz vsebin predmeta predhodne izvedbe sposobni izvesti tudi sami. Zgodnje odpiranje predmetov se je kljub možnim kasnejšim spremembam izkazalo za uporabno. Učitelji različno načrtujejo svoje dopuste, tako da ima vsak dovolj časa za pravočasno pripravo na novo študijsko leto. Nosilec predmeta, odgovoren za pripravo e-učilnice, podpori sporoči še druge sodelavce, ki so predvideni za izvedbo.

Učitelji imajo pri uporabi e-učilnice različne pristope, kar se kaže tudi pri načinu vključevanja študentov in zaključevanju izvedbe predmeta. Učitelji študente na osnovi seznama študentov iz šıs-a lahko vključijo sami, lahko odprejo t.i. samovpis (prost vstop) ali pa študentom na prvem srečanju povedo ključ za vpis v predmet in se študentje vpišejo na njegovi osnovi. Ob zaključku predmeta nekateri učitelji predmet zaprejo, študente $\mathrm{z}$ neopravljenimi obveznostmi pa preusmerijo $\mathrm{v}$ predmete, ki so namenjeni podpori študentov prejšnjih generacij (primer na sliki 4.2). Drugi predmete pustijo odprte do zaključka študijskega leta. Ne glede na pristop se celotna kategorija študijskega leta ob zaključku študijskega leta (30. septembra vsakega leta) zapre. Zapiranje pomeni, da študentje do predmeta nimajo več dostopa, so pa predmeti za učitelje še vedno dostopni. Učitelji lahko dostopijo do vsebin, dostopna pa je tudi vsa statistika obiska pri predmetu oziroma imajo učitelji pregled nad opravljenimi aktivnostmi študentov, kar pride prav ob kasnejšem pristopu študenta k izpitu in morebitnem uveljavljanju opravljenih vaj ali drugih $\mathrm{z}$ učnim načrtom predvidenih obveznosti.

Učitelji svoje e-učilnice uredijo skladno z načrtom izvedbe predmeta. Ta temelji na učnem načrtu predmeta, podrobno pa opredeljuje razporeditev vsebin po tednih ali temah, razporeditev organiziranih oblik dela (predavanja, vaje, seminarji), pregled izvajalcev predmeta ter vse obveznosti študentov. V načrtu izvedbe so razvidni tudi učni izidi, predvideni za posamezno temo ali teden.

\subsection{Izvedba pedagoškega procesa med epidemijo}

UP je t. i. »lockdown« izvedla že teden pred nacionalno razglašeno epidemijo. Prvotno je bilo napovedano le 14-dnevno zaprtje, vendar je bilo kmalu jasno, da bo zaprtje daljše.

Učitelji U P F M so od vodstva fakultete dobili na izbiro, da pedagoški proces izvedejo v e-obliki, če pa tega ne morejo, pa da naj o tem obvestijo strokovno službo in se bo izvedba pomaknila na kasnejše obdobje. 

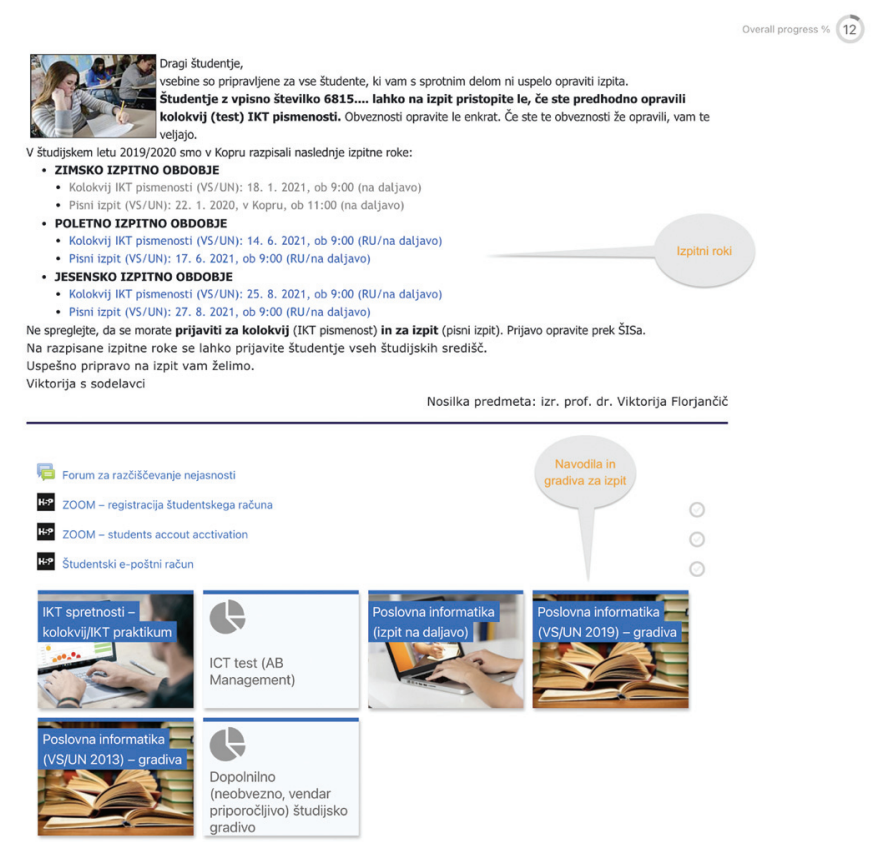

Slika 4.2 Podpora študentom prejšnjih generacij za predmete s področja poslovne informatike

Vsi učitelji, razen enega, ki je izvedbo predmeta prenesel v 4. kvartal, so svoje predmete izvedli v tekočem kvartalu. Medtem ko so ostale članice UP čakale na nadaljnja navodila rektorata, so učitelji U P F M že v prvem tednu zaprtja univerze s pedagoško dejavnostjo nadaljevali prek videokonferenčnega sistema Arnes Vox, ${ }^{7}$ s katerim so imeli izkušnje že iz študijskega leta 2017/2018.

\section{Priporočila za poučevanje na daljavo v izrednih razmerah}

V prvem tednu zaprtja UP smo v projektni skupini InoTeZ pripravili priporočila za poučevanje na daljavo v izrednih razmerah. ${ }^{8}$ Izhajala so iz testiranja različnih tehnologij, ki smo jih preverili in presodili njihovo primernost za uporabo. Predlagali smo tehnologije, ki podpirajo komu-

${ }^{7}$ Glej https://vox.arnes.si/.

${ }^{8}$ Glej https://odprtaup.upr.si/mod/book/view.php?id=882. 
nikacijo s študenti, posredovanje znanja študentom in sodelovalno delo z njimi. Prvotno smernic za izvedbo izpitov na daljavo nismo pripravili, saj smo upali, da bo »lockdown« kratkotrajen. Smernice za izvedbo izpitov na daljavo smo v priporočila vključili kasneje, in sicer na osnovi izkušenj z izvedbo kvartarnega izpitnega roka na U P F M.

Pri izbiri tehnologij za vključitev v priporočila smo upoštevali predvsem naslednje kriterije:

- dostopnost - prednost smo dali brezplačni in odprtokodni programski opremi ali opremi, ki je že v uporabi na U P oziroma ima UP zanjo neposredno ali posredno zakupljene licence (npr., programska oprema MS 0365 je učiteljem in študentom dostopna prek licenc, zagotovljenih na ravni države); poleg tega smo preverili še način dostopa do programske opreme - ali si mora študent ustvariti uporabniški račun ali pa do programske opreme/storitve dostopa prek enotne A AI-prijave; možnost slednje je bila pri izbiri programske opreme ključna;

- enostavnost uporabe;

- urejena podpora uporabnikom - na U P ali na članicah U P ali pa podporo nudi proizvajalec programske opreme.

V nadaljevanju predstavljamo tehnologijo, ki smo jo uporabljali na UP FM.

\section{E-učilnica Moodle}

Osrednja programska oprema, pred in tudi med epidemijo, je nedvomno Moodle, ki ga od vsega začetka uporabe v študijskem letu 2003/2004 imenujemo e-učilnica (eucilnica.si). Učitelji seveda e-učilnico uporabljajo na različne načine - od zelo enostavne, osnovne rabe do podpore izvedbe predmeta online. V času epidemije se je e-učilnica uporabljala intenzivneje, saj je bil to osrednji kanal komunikacije s študenti. Pred korono so nekateri učitelji študentom na prvih predavanjih pogosto sporočili ključ za vpis v e-učilnico, v koronskem času pa ta možnost ni obstajala, saj so se učitelji s študenti prvič srečali na spletu. Zato se je praksa spremenila $\mathrm{v}$ vključevanje študentov $\mathrm{v}$ e-učilnico pred začetkom izvedbe, študente pa je učitelj obveščal prek Foruma obvestil. V študijskem letu 2019/2020, predvsem pa v študijskem letu 2020/2021 je e-učilnica uporabljana bolj kot kadar koli do sedaj. To je razvidno tudi iz Moodlove statistike. Iz podatkov smo izluščili 90 najdejavnejših predmetov (utežena dejavnost uporabnika) v zadnjih štirih letih (pre- 
4 E-izobraževanje na U P F M

Preglednica 4.3 Struktura najdejavnejših predmetov po letih

\begin{tabular}{lrr}
\hline Študijsko leto & Število predmetov & Delež predmetov (\%) \\
\hline $2020 / 2021$ & 35 & 39 \\
$2019 / 2020$ & 29 & 32 \\
$2018 / 2019$ & 10 & 11 \\
$2017 / 2018$ & 16 & 18 \\
\hline Skupaj & 90 & 100 \\
\hline
\end{tabular}

glednica 4.3). Delež števila predmetov, ki se uvršča med 90 najdejavnejših, je največji v študijskem letu 2020/2021 (39\%), nekoliko manjši pa je bil v študijskem letu 2019/2020 (32\%). Podatki dokazujejo, da je bila e-učilnica U P F M res osrednja "predavalnica « v času epidemije in da se je prek nje izvedel večji del pedagoškega procesa.

Povečan obseg uporabe in aktivnost je razviden tudi iz slike 4.3. Iz Moodlove statistike smo zbrali podatke o vseh dejavnostih vseh uporabnikov e-učilnice za zadnja štiri leta. Če pogledamo podatke za študijski leti pred epidemijo (2017/2018 in 2018/2019), opazimo, da imata grafa kljub različnemu številu študentov (preglednica 4.2) podobno obliko. Na začetku leta zabeležimo skok števila uporabnikov, le-to kasneje pada in dno doseže ob zaključku prvega (zimskega) semestra. V drugem (letnem) semestru se intenzivnost uporabe zopet povečuje, vendar ne doseže ravni prvega semestra (osip študentov med letom). Ob zaključku semestra se obisk e-učilnice zniža in čez poletje miruje. Iz grafa je razvidno, da se obisk e-učilnice začne povečevati v času jesenskih izpitnih obdobij. Na začetku študijskega leta 2019/2020 (slika 4.3) je bil obisk e-učilnice precej podoben predhodnima letoma, vendar ob zaključku prvega semestra ni tako zelo upadel kot v preteklih dveh letih. Marca 2020, z razglasitvijo epidemije, pa se je intenzivnost uporabe e-učilnice naglo dvignila, in to kljub najnižjemu številu vpisanih študentov v zadnjih štirih letih (preglednica 4.2). V študijskem letu 2020/2021 je število študentov sicer nekoliko večje, vendar intenzivnost uporabe eučilnice močno presega intenzivnost pred epidemijo. In zanimivo, tudi v študijskem letu 2020/2021 se aktivnost ob zaključku prvega semestra ne spusti nizko - to nakazuje uporabo e-učilnice v zimskem izpitnem obdobju.

Statistika uporabe e-učilnice, prikazana na sliki 4.3, potrjuje podatke o pretežni rabi e-učilnice Moodle na UP F M za poučevanje na daljavo (preglednica 3.5). E-učilnica se uporablja tudi za preverjanje in ocenje- 


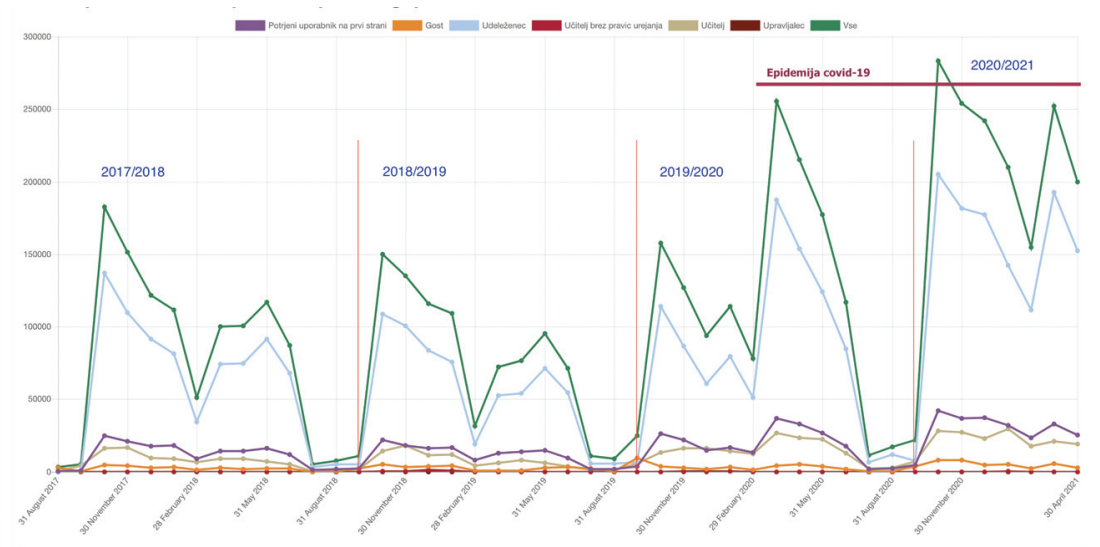

Slika 4.3 Aktivnost v e-učilnici U P F M

vanje znanja na daljavo (preglednica 5.1). Večina aktivnosti v Moodlu podpira asinhroni način dela, ki ne zahteva sočasne prisotnosti učitelja in študentov. Izjema je dejavnost Klepet, ki se izvaja le ob sočasni prisotnosti udeležencev klepeta. Je pa dejavnost v praksi manj uporabljena in le izjemoma, ko se predvideva sinhrono sodelovanje. V nadaljevanju podajamo primer dodatne podpore med izvedbo izpita na daljavo.

\section{MS Teams}

Microsoft aplikacijo Teams (M Teams) predstavlja kot središče za timsko delo v storitvi Office $365 .{ }^{9}$ Člani posamezne Ekipe (angl. Team) lahko komunicirajo (klepet, glasovni in videoklici) in sodelujejo med sabo, si izmenjujejo dokumente in jih tudi skupaj urejajo. Aplikacija je bila prvotno namenjena poslovnim uporabnikom, leta 2017 pa jo je Microsoft vključil v storitev 0365 Education, ki je namenjena izobraževalnim organizacijami. MS Teams lahko uporabljamo kot namizno ali spletno aplikacijo.

Do marca 2020 aplikacije na U P še nismo poznali, pa čeprav 0365 uporabljamo že dolgo. $Z$ njo smo se začeli spoznavati šele, ko smo ugotovili, da Arnes vox ne bo zmogel pokriti vseh potreb po videokonferenčnih povezavah. MS Teams namreč omogoča tudi videopovezave (sinhroni način dela), v katere se lahko poveže večje število sodelavcev ali pa učitelj s študenti (učenci). Na začetku videopovezave, sklenjene prek Ms Teams, niso bile najboljše - prihajalo je do motenj, slika je za-

\footnotetext{
${ }^{9}$ Glej https://www.microsoft.com/en-ww/microsoft-teams/group-chat-software.
} 
mrznila, zvok je prihajal z zamudo ipd., tako da se za uporabo aplikacije nismo odločili oziroma so jo uporabljali le učitelji, ki so imeli manjše število študentov. Microsoft je $\mathrm{v}$ času epidemije vložil veliko napora $\mathrm{v}$ dopolnjevanje aplikacije in tudi v izobraževanje uporabnikov, tako da je aplikacija po letu dni precej drugačna in očitno dopolnjena ter izboljšana; omogoča npr. nastavitev navideznega ozadja, povezave so stabilnejše, tu je možnost vključevanja večjega števila uporabnikov itn. Zato ne preseneča, da se veča tudi število uporabnikov.

Uporaba M S Teams je v slovenskem prostoru razširjena na douniverzitetnem izobraževanju, $v$ visokem šolstvu pa ga uporablja predvsem Univerza v Mariboru. Na U P smo imeli na začetku precej težav z nastavitvami in dodeljevanjem pravic za uporabo, kar je seveda povezano $\mathrm{s}$ prejšnjo neuporabo. Počasi smo aplikacijo usposobili za delo, posameznikom dodelili možnost odpiranja Ekip in testiranja zmožnosti aplikacije. Hitro smo spoznali prednosti Ms Teams in ga uvedli kot podporo sodelovalnega dela strokovnih služb na UP F M ter podporo vseh zaposlenih. S prenosom poučevanja na splet smo v MS Teams odprli ekipo $\mathrm{z}$ imenom eF $\mathrm{M}$ in prek nje preusmerili vso komunikacijo o uporabi I K T pri delu na daljavo (slika 4.4). Na ta način smo zmanjšali količino e-poštnih sporočil, predvsem pa na enem mestu zbrali vse informacije, potrebne za uspešno in učinkovito delo s študenti. Prek ekipe e F M smo učitelje obveščali o novostih, potrebnih posodobitvah programske opreme (npr. ko je zo o M odpravil posamezno ranljivost programa), namigih za nastavitve posameznih programov itn. V ekipo smo prvotno vključili le visokošolske učitelje in sodelavce U P F M, kasneje pa smo dodali tudi strokovne službe. Na ta način smo vse zaposlene povezali na enem uporabniku prijaznem spletnem mestu in jih tako vse povezali $\mathrm{v}$ eno učečo se skupnost. Prek ekipe ef M smo na začetku epidemije sklicali tudi več videosrečanj, kar je učiteljem pomagalo pri premagovanju začetniških težav. MS Teams še danes uporabljamo za hitri klic in videopomoč $1: 1$. V projektu InoTeZ je sicer nastal portal Odprta U P, do katerega smo povezavo vključili tudi v ekipo E F M, se je pa MS Teams vseeno izkazal za uporabniku prijaznejši in preglednejši način. Prednost aplikacije je predvsem v hitri sinhroni (videoklic) ali asinhroni (sporočila prek klepeta) komunikaciji. Zanimivo je, da so bili v Ms Teams, najbrž zaradi uporabniku prijaznega uporabniškega vmesnika, aktivni posamezniki, ki e-učilnice do sedaj sploh niso uporabljali.

Glede na to, da je odpiranje ekip v M S Teams omejeno - vsaki ekipi se namreč odpre mesto na portalu SharePoint - in da v pedagoškem pro- 


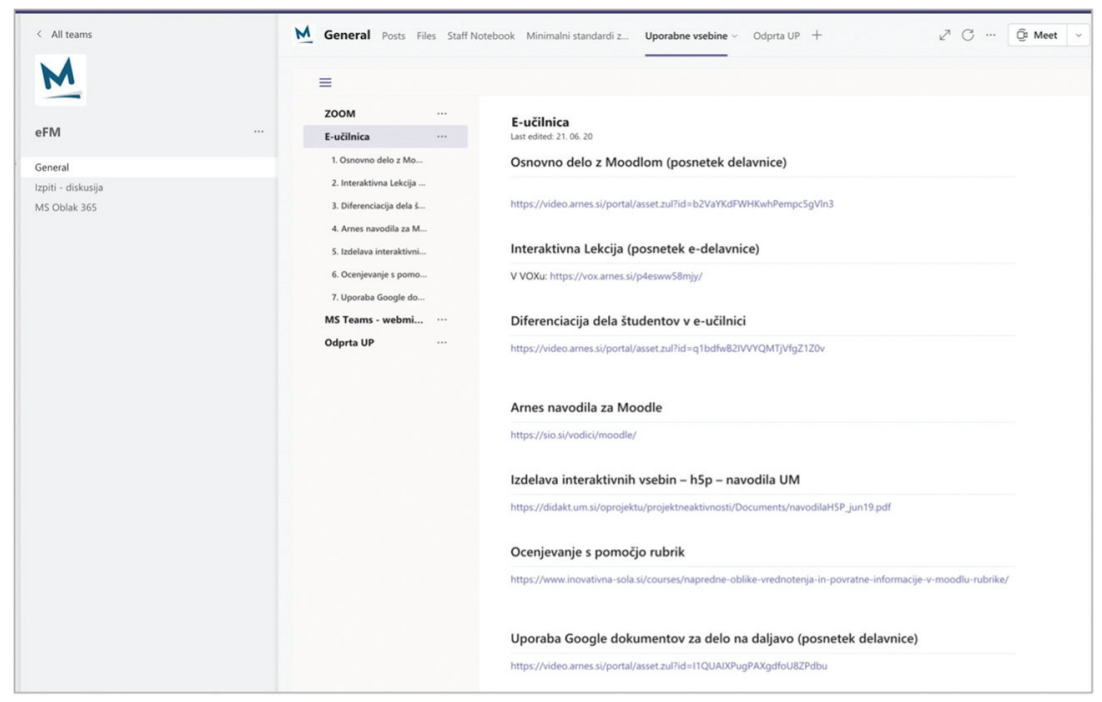

Slika 4.4 Podpora učiteljem v MS Teams

cesu uporabljamo Moodle, se MS Teams za podporo izobraževalnega dela ne uporablja. Se pa aplikacijo uporablja za podporo dela posameznih delovnih in projektnih skupin ter za vodenje posameznih sestankov strokovnih služb oziroma hitro podporo pri odprtih vprašanjih $v$ klepetu ekipe ef M.

\section{Videokonferenčni sistemi}

Ms Teams je okolje, ki bi ga lahko uporabili namesto Moodla, hkrati pa tudi za izvedbo videokonferenčnih srečanj (predavanj). Ker se Moodle na UP F M uporablja že od študijskega leta 2003/2004, o tem še nismo razmišljali. $V$ okviru sodelovanja na področju raziskovanja $z$ univerzo v Lublinu (Poljska) smo sicer izvedli študijo primerljivosti Moodla in MS Teams, ki je za institucije, ki že dolga leta uporabljajo Moodle, pokazala številne prednosti slednjega (Florjančič in Wiechetek v tisku). MS Teams smo prikazali kot aplikacijo, ki omogoča sinhrono in asinhrono delovno okolje. $Z$ epidemijo in uvedbo poučevanja na daljavo se je pojavila potreba po sinhroni komunikaciji celotne skupine študentov. Takšen način dela omogočajo videokonferenčni sistemi. Do epidemije so imeli posamezni učitelji, predvsem prek projektov, izkušnje udeleženca $v$ različnih videokonferenčnih sistemih, $v$ pedagoški praksi pa se je večinoma uporabljal predvsem Arnes vox, pred leti pa tudi Google Hangouts. 
Arnes $\operatorname{VOX}^{10}$

Videokonferenčni sistem Vox, ki uporablja programsko opremo AdobeConnect, ${ }^{11}$ ponuja Arnes, zato v praksi govorimo kar o Arnes vox. Arnes je imel za videokonferenčni sistem vox zakupljeno omejeno število licenc, česar številni uporabniki do popolnega zaprtja države nismo vedeli. Videokonferenčni sistem smo posamezni učitelji že dolgo uporabljali za izvedbo posameznih predavanj, ki se niso mogla izvesti na daljavo. Tako smo npr. izvedli posamezna predavanja na izrednem študiju ali kratka tedenska srečanja pri predmetih, ki so se izvajali na daljavo, in za predavanja učiteljev iz tujine. Prek vox-a smo izvedli tudi posamezne zagovore diplom, če kakšen član komisije fizično ni mogel biti prisoten na lokaciji zagovora ali pa je študent diplomo zagovarjal iz tujine. Zaradi teh izkušenj je bila uporaba Arnes vox-a ob zaprtju fakultete logična in enostavna izbira. Prve dni smo vse videokonference izvedli brez težav, potem pa so posamezni učitelji že začeli poročati o težavah z vključevanjem uporabnikov v videokonferenčne sobe. Zato smo že pred iztekom prvega tedna, ko smo spoznali, da je število licenc omejeno in da se bodo kmalu pridružile še osnovne in srednje šole ter preostala visokošolska skupnost, začeli preučevati alternative.

Poleg enostavnosti uporabe in navajenosti na Vox so k odločitvi zanj prispevale še naslednje značilnosti:

- VOX omogoča A A I-prijavo, ki olajša vključevanje študentov in sledljivost prisotnih;

- VOX omogoča vnaprejšnjo naložitev vseh potrebnih dokumentov, ki bodo uporabljeni na srečanju - npr., pri predstavitvi nalog študentov/skupin so študentje učitelju posredovali predstavitve, kijih je učitelj naložil v sistem in s tem olajšal potek predstavitev;

- posnetki predavanj/srečanj se hranijo znotraj sistema Vox, povezavo do posnetka pa učitelj deli prek e-učilnice; tako shranjeni posnetki ohranijo zasebnost in varnost, predvsem zato, ker se vse to hrani na Arnesovih strežnikih v Sloveniji;

- videokonferenčni sistem vox vzdržuje Arnes, ki uporabnikom nudi tudi vso potrebno podporo.

Vse dokler nismo začeli uporabljati zo o M-a, smo vox predstavljali kot program s prijaznim uporabniškim vmesnikom.

${ }^{10}$ Glej https://vox.arnes.si/.

${ }^{11}$ Glej https://www.adobe.com/products/adobeconnect.html. 


\section{$Z O O M^{12}$}

Omenili smo, da so nekateri učitelji kot udeleženci videokonferenc ( $\mathrm{v}$ okviru projektov ali spletnih seminarjev) že imeli izkušnje $\mathrm{z}$ različnimi videokonferenčnimi sistemi. zoOM je eden od njih, zato je postal tudi eden od prvih sistemov, ki so bili podvrženi testiranju. Že ob prvi uporabi smo bili nad njim navdušeni - imel je prijazen in predvidljiv uporabniški vmesnik, ki olajša uporabo sistema.

Ameriško podjetje zoom je ustanovil Eric Yuan, predhodno zaposlen pri podjetju Cisco, ponudniku videokonferenčnega sistema WebEx. ${ }^{13}$ Nezadovoljstvo uporabnikov WebExa in neupoštevanje njihovih pripomb v Ciscu je Yuana vzpodbudilo, da je podjetje zapustil in ustanovil podjetje zOOM (Atkinson 2020). Videokonferenčni sistem zOOM je trgu ponudil leta 2013. zOOM je v medijih od začetka epidemije dalje znan po številnih pripombah na račun ranljivosti sistema. Kronološki pregled ranljivosti je zbran na spletni strani Tom's Guide. ${ }^{14}$ Nekatere ameriške univerze so na začetku epidemije uporabo zoo M-a celo prepovedale ali odsvetovale (podobni nasveti so bili tudi v Sloveniji), vendar so jo, zaradi značilnosti aplikacije in hitrega odpravljanja izkazanih ranljivosti, kmalu začele ponovno priporočati. V E U so se pri izbiri ustreznega videokonferenčnega sistema ukvarjali $z$ vprašanji skladnosti z evropsko direktivo o varovanju osebnih podatkov (General Data Protection Regulation - G D P R), predvsem z vprašanji, kje se hranijo podatki udeležencev, kaj se hrani, kdo ima dostop do podatkov itn. Če so se na začetku vse videokonference prenašale prek strežnikov v Z DA, pa videokonferenčni prenos za licencirane uporabnike iz E U poteka prek strežnikov v E U, večinoma prek Nemčije. Začetni prenosi niso bili šifrirani, kasneje pa se je tudi to uredilo. Obvestilo o skladnosti aplikacije Z OOM z GDPR je objavljeno na spletni strani. ${ }^{15}$ Seveda pa strokovnjaki za varnost na internetu še vedno opozarjajo na ranljivost $\mathrm{zo} O \mathrm{M}-\mathrm{a}$ (Wagenseil 2021).

Na U P F M smo spomladi 2020 nabavili nekaj deset licenc zo o M-a za poslovne uporabnike in tako brez težav izpeljali pedagoški proces. Podobno so naredile še nekatere druge članice U P. V začetku študijskega

\footnotetext{
${ }^{12}$ Glej https://zoom.us/.

${ }^{13}$ Glej https://www.webex.com/.

${ }^{14} \mathrm{Glej}$ https://www.tomsguide.com/news/zoom-security-privacy-woes.

${ }^{15} \mathrm{Glej}$ https://upr-si.zoom.us/en-us/trust/privacy.html - povezava do obvestila na spletnem mestu zakupljenih licenc za UP.
} 
leta 2020/2021 pa je UP za vse svoje učitelje in študente z zOOM-om sklenila enoletno naročnino za izobraževalne institucije, kar nam je vsem olajšalo delo. Z zoOM-ovo licenco smo pridobili možnost snemanja predavanj na oblak, ne samo na zasebni računalnik, snemali so lahko tudi študentje, učitelji smo imeli pregled nad vključevanjem študentov v aplikacijo (prijava je bila pogojena le s šolskim računom), $\mathrm{v}$ Moodle smo vgradili vtičnik za zoom itn.

Pri uporabi videokonferenčnega ZOOM-a na UP FM izpostavljamo naslednje prednosti:

- prijava študentov s šolskim računom zoom je zagotovila prepoznavo (podobno kot to naredi A I-prijava) in evidenco prisotnih;

- uravnavanje vključevanja udeležencev prek domene - študentje U P so lahko takoj vstopili v videokonferenčno sobo, ostali pa so čakali $\mathrm{v}$ čakalnici; čakajočega v čakalnici v videokonferenco spusti učitelj (primer: vključevanje gostov iz prakse);

- oblikovanje skupin in samodejno razporejanje študentov po njih;

- možnost snemanja na oblak in deljenje posnetka prek e-učilnice;

- pregled statistike ogleda vsakega posameznega posnetka, iz katere je razvidno, kdo in kdaj si je posnetek ogledal ter koliko časa se je zadržal pri njem;

- možnost vključevanje večjega števila študentov - v praksi smo imeli tudi več kot 100 študentov z vključenimi kamerami;

- personalizacija in zasebnost - uporabnik si lahko namesti poljubno ozadje in s tem zakrije zasebne prostore;

- možnost izražanja mnenj in čustev prek ikon (ploskanje, znak O K ipd.) ter vključevanje $\mathrm{v}$ diskusijo $\mathrm{z}$ dvigom roke;

- omogočanje snemanja dela na računalniku - z zo o M-om smo pripravili videovodiče o uporabi posameznih orodij, študentje pa so prek snemanja reševanja nalog opravljali izpit pri I K T praktikumu.

V prvem valu epidemije smo testirali še BigBlueButton, ${ }^{16} \mathrm{Jitsi}^{17}$ in Webex. $^{18}$

Veliko smo si obetali od odprtokodnega videokonferenčnega sistema BigBlueButton, ki je prek vtičnika dostopen tudi v Moodlu. ${ }^{19}$ Videokon-

\footnotetext{
${ }^{16}$ Glej https://bigbluebutton.org/.

${ }^{17}$ Glej https://jitsi.org/.

${ }^{18}$ Glej https://www.webex.com/.

${ }^{19} \mathrm{Glej}$ https://moodle.org/plugins/browse.php?list=set\&id=2.
} 
ferenčni sistem je enostaven za uporabo, vendar ne podpira večje skupine študentov. Zahteva tudi lokalno namestitev (in vzdrževanje) programske opreme, za kar na univerzi ni bilo prostih virov. Sicer pa integracija $\mathrm{z}$ Moodlom, čeprav je videti enostavno in uporabno, vsem ni všeč. V praksi se nam je v zo o M-u veliko bolje obneslo, da smo za vsak predmet odprli po eno videokonferenčno sobo; poimenovali smo jo kar spletna predavalnica, študentje pa so pri predmetu vedno vstopili v isti virtualni prostor.

Zanimiv in enostaven za uporabo je odprtokodni videokonferenčni sistem Jitsi, ki smo ga imeli nameščenega na enem od strežnikov U P, ob zlomu sistema vox pa ga je namestil tudi Arnes. Videokonferenčni sistem je Arnes poimenoval Arnes VID. ${ }^{20}$ Ena glavnih slabosti sistema je, da ne omogoča snemanja. So pa Jitsi v zadnjem letu izpopolnili, saj so dodali možnost neposrednega prenosa predavanja na splet in testno zameglitev ozadja (je še v beta različici).

Webex je bil na testiranju nestabilen, tako da smo se mu takoj odpovedali. V okviru projekta InoTeZ smo tako predlagali uporabo drugih predstavljenih videokonferenčnih sistemov, na U P F M pa smo se odločili za zooM.

\section{Exam.net ${ }^{21}$}

Exam.net je švedska izpitna platforma, ki je bila razvita za potrebe izobraževalnih institucij na Švedskem. Poleg švedske jezikovne različice je dostopna še v nemščini in angleščini. $V$ času prvega vala epidemije smo jo lahko uporabljali brezplačno. ${ }^{22}$ Podjetje ima dobro organizirano podporo - tako na spletni strani kot tudi po e-pošti. Podporne strani ${ }^{23}$ so nam bile v pomoč pri snovanju strategije za opravljanje izpita na daljavo, ki smo jo seveda prilagodili svojim potrebam in razmeram. V prvem valu epidemije platforma ni omogočala izpitnih vprašanj $v$ obliki kviza, so pa to kasneje dodali. Učitelji so vprašanja vpisali v sistem ali pa jih študentom posredovali prek dokumenta PDF. Kasneje so razvijalci dodali še različna testna vprašanja, kar izpit naredi pestrejši, učitelj pa z njihovo oceno nima dela (slika 4.5), saj odgovore oceni sistem.

\footnotetext{
${ }^{20}$ Glej https://vid.arnes.si/.

${ }^{21}$ Glej https://exam.net/.

${ }^{22}$ Platforma je postala plačljiva 1. januarja 2021. Na U P F M smo zakupili letne licence za uporabo exam.net. Strošek uporabe ni pretirano visok ( $4 €$ na študenta na leto).

${ }^{23}$ Glej https://support.exam.net/\#/getstarted.
} 
No digital exam questions

The questions are given outside of the system, e.g. orally or on a piece of paper.

Use a PDF file

Add or change your choice of a PDF-file. You can add additional PDF files under "Resources"

Write exam questions

Write your questions here, or paste from Microsoft Word.

Auto-marked exams

create exams with different question types such as "multiple choice", "fill in the gaps", etc. You can also enable auto-marking for

Slika 4.5 Exam.net-vprašanja

Exam.net se lahko uporablja tudi za izpite, kjer bi npr. učitelj vprašanja postavil ustno ali pa bi jih študentje dobili napisana na listu papirja, če bi se izpit izvedel v klasični učilnici.

V nadaljevanju prikazujemo primer izpita, kjer so vprašanja postavljena v obliki dokumenta P D F, kar simulira klasični izpit, ki pa se zaradi epidemije opravlja na daljavo. Učitelj pri izpitu nastavi, kateri osebni podatki študenta se bodo zbrali. Pri izpitu na daljavo ali pa izpitu, ki se odvija v računalniški učilnic pod učiteljevim nadzorom, je dovolj, če študent vpiše svoje ime in priimek ter vpisno številko (slika 4.6).

Exam.net učitelju omogoča, da delovno okolje nastavi po potrebi (slika 4.7). Za potrebe pisanja odgovorov, kakršen je primer izpita, ki ga navajamo v nadaljevanju, smo vključili »writing area«, kar študentu omogoča prosto pisanje odgovorov (glej okno za vnos besedila na sliki 4.10). Vključitev črkovanja (angl. spell check) je možna le za omejen nabor jezikov; slovenščine ni med njimi. Če študentje pišejo odgovore na papir, moramo vključiti možnost slikanja odgovorov z mobilnim telefonom ("Scan handwritten work with a mobile phone« na sliki 4.7). V izpit na exam.net lahko vključimo zvočne datoteke, s katerimi lahko npr. preverimo slušno razumevanje pri tujem jeziku. Exam.net ima naslednja orodja:

- orodje za risanje (angl. Drawing tool), kjer študent nariše shemo ali pa npr. naložimo sliko, na kateri je potrebno kaj označiti, dodatno narisati ipd. (priloga 7); 


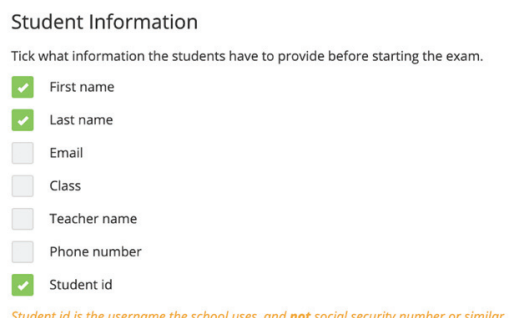

Anonymize exam

Students' identities are replaced by unique codes, and you may reveal the identities after grading the exams.

How does this work?

Slika 4.6 Exam.net-osebni podatki študenta

- kalkulator, če izpit zahteva izračune - tako od študenta lahko zahtevamo (in mu tudi omogočimo), da uporablja le kalkulator v izpitni platformi, ne pa drugih tovrstnih pripomočkov;

- GeoGebra - interaktivno orodje za izpite s področja matematike in statistike; izbiramo lahko med tremi nastavitvami: Classic (prilogi 2 in 3), Graphing (priloga 4) in Geometry (priloga 5);

- Desmos - grafični kalkulator za risanje grafov (priloga 6);

- osnovne ali napredne matematične formule; ob pripravljenem naboru slednjih lahko za študente pripravimo predmetnospecifičen nabor formul in jih v izpit dodamo kot dokument P DF - na ta način imajo študentje na izpitu vse, kar potrebujejo, in na mizi ne smejo imeti ničesar razen miške in tipkovnice;

- orodja za programiranje v JavaScriptu ali Pyhtonu (angl. programming) (priloga 1).

Naj poudarimo, da vključevanje grafičnih orodij v izpit zahteva predhodno učenje in uporabo teh orodij pri pedagoškem delu.

V izpit lahko vključimo še zunanje vire - npr. že omenjeni dokument P DF z enačbami ali kakšna druga gradiva (npr. članek, poglavja iz knjig - izpit pri odprti knjigi). Dodajanje povezav na splet se je v času nastajanja monografije izkazalo za manj uporabno oziroma ne deluje, kot 
Writing area

0

The student is given an area to write answers in.

Spell check

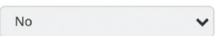

Checks the spelling and gives suggestions to misspellied words

Scan handwritten work with a mobile phone

Gives the student the ability to scan handwritten work. It does not require any specific app, but the device need to be able to read QR codes (built into the camera of most modern phones).

(A) Accessibility tools

$\checkmark$ Audio files

$\checkmark$ 曲 Subject tools

๑ Resources

Slika 4.7 Exam.net - nastavitev študentovega delovnega okolja

bi bilo pričakovati. Vsak skok na splet seveda predstavlja možnost za odpiranje dodatnih oken $\mathrm{v}$ brskalniku in $\mathrm{s}$ tem možnost goljufanja na izpitu.

Na koncu nastavimo še varnostne nastavitve (slika 4.8). Priporočamo uporabo najvišje stopnje varnosti, kjer se izpit odpre v varnem oknu brskalnika (Safe Exam Browser - SEB). Vsaka druga nastavitev izpita poveča možnost goljufanja.

SE B prek exam.net deluje brez težav. Edina težava, ki smo jo opazili, je nedelovanje SEB, kar sicer ni težava exam.net, ampak gre za nedelovanje $\mathrm{SE} B-a$ na računalnikih $\mathrm{z}$ operacijskim sistemom Linux. Po naših izkušnjah študentov U P F M, ki bi uporabljali ta operacijski sistem, ni, so pa lahko na kakšnih drugih študijskih programih (npr. računalništvu). Pri izvajanju izpitov prek exam.net je študente potrebno opomniti, da 
Require high-security mode

Exam.net-applications (iOS and macOS), SEB (Windows), TaT (Windows 10) or the Chromebook-app. High security mode settings

The high-security mode is recommended as soon as the necessary software is installed. See the foot of the page for installation.

Allow any browser but prefer high-security mode

High-security mode will be suggested, but the student may also start the exam in any browser. You can see when monitoring the exam if the student is using the high-security mode.

Allow any browser

The exam will open in any browser

Slika 4.8 Exam.net - varnostne nastavitve

pred vsakim izpitom posodobijo operacijski sistem in tudi SEB, saj se s tem sproti odpravljajo ranljivosti programa. Študentom pred izpiti na daljavo priporočamo, da v kolikor ne ugašajo računalnika čez noč, pred izpitom opravijo ponovni zagon sistema in ob zagonu zaženejo le programe, ki so nujno potrebni za opravljanje izpita.

Učitelji na UP F M smo se že pred nabavo licence za exam.net povezali pod imenom iste šole, tako da si sedaj lahko delimo izpite, v izpit vključujemo sodelavce itn. Gre torej za uporabno zmožnost programa, ki omogoča sodelovanje pri pripravi in tudi izvedbi izpita.

V nadaljevanju prikazujemo vidik študenta. Prednost platforme exam .net je zanj nedvomno v tem, da za opravljanje izpitov prijava na exam .net ni potrebna. Študent vnese le ključ za dostop do izpita (slika 4.9) in podatke, ki jih učitelj zahteva (slika 4.6). Naj omenimo, da se vsi izpiti po 180 dneh od nastavitve arhivirajo in po treh letih dokončno zbrišejo, s tem pa tudi vsi za potrebe izpita zbrani osebni podatki študentov. Učitelj arhiviranega izpita ne more več uporabiti, lahko pa naredi njegovo kopijo, če bi ga želel ponoviti ali ga ponovno uporabiti.

Glede na varnostne nastavite izpita (slika 4.8) mora študent namestiti le SEB, do katerega je povezava objavljena na exam.net.

Študent do izpitne pole dostopi z vnosom ključa (angl. exam key) (slika 4.9). Učitelj lahko v nastavitvi izpita nastavi, da se izpit vsem študentom odpre naenkrat. Torej, četudi študent vnese ključ za reševanje izpita, se mu ta, če je učitelj tako nastavil, še ne odpre. To se pokaže uporabno, ko je študentov v skupini več in nimajo vsi enako hitre internetne povezave. Čas reševanja izpita se, če ga je učitelj nastavil, študentu izpi- 


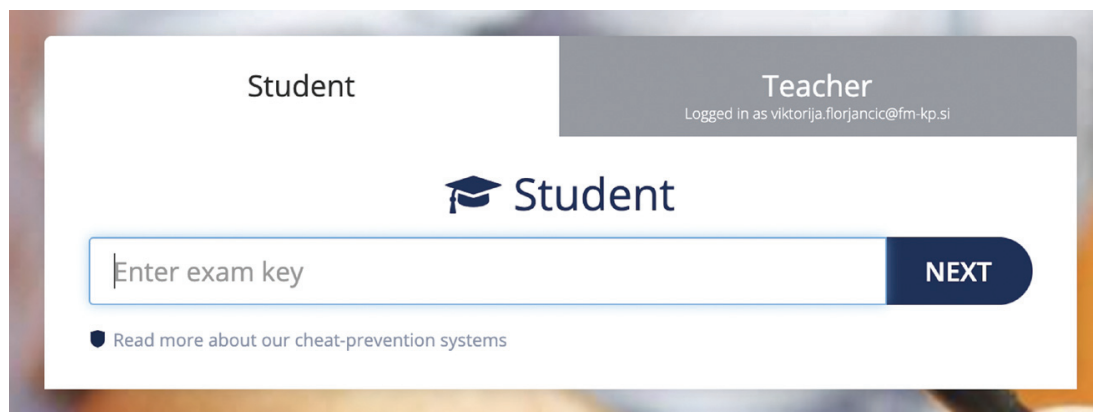

Slika 4.9 Exam.net - vstop študenta

suje na zaslonu; čas reševanja seveda lahko nastavimo šele takrat, ko vsi študentje vstopijo $\mathrm{v}$ izpit, s čimer izničimo razlike $\mathrm{v}$ hitrosti internetne povezave študentov.

Če je izpit nastavljen na najvišjo varnost (priporočamo, da se uporablja le ta možnost), se študentu vsa ostala okna na računalniku zaprejo in odpre se le varno okno brskalnika. V kolikor ima študent na računalniku priključena dva zaslona, se SEB ne zažene in uporabnika opozori, da mora dodatni zaslon odstraniti. Onemogočijo se tudi vsi sistemi za komunikacijo (npr. Skype, M S Teams, TeamViewer), razen zo o M-a, če je bil ta vzpostavljen kot nadzor nad opravljanjem izpita. ${ }^{24}$ Študent si izpitno okolje lahko prilagaja po meri. Tako lahko npr. spremeni postavitev oken (vodoravna ali horizontalna postavitev), velikost oken pa tudi prikaz besedila v izpitni poli, kar je dobrodošlo za vse, ki imajo težave $\mathrm{z}$ vidom (slika 4.10). Komunikacija z učiteljem poteka prek platforme, kar je za ostale prisotne povsem nemoteče.

Med izvedbo izpita ima učitelj popoln pregled nad reševanjem, posebno $v$ primeru neposrednega vnosa odgovorov v sistem. Iz nadzorne plošče izpita je vidno, kdaj je študent začel reševati izpit in kdaj ga je oddal oziroma ali so bili vmes kakršni koli poskusi zapiranja varnega okna brskalnika. V kolikor učitelj opazi kakršno koli ravnanje, ki ni skladno z izpitnim protokolom, lahko reševanje izpita za posameznega študenta prekine - tega v Moodlu ne more narediti. Prednost je tudi v komuni-

\footnotetext{
${ }^{24} \mathrm{~V}$ začetku junija 2021 je na trg prišla nova različica SafeExamBrowserja (3.2), ki uporabniku ob zagonu zapre tudi videokonferenčni sistem zooM. Zato učiteljem priporočamo uporabo različice 3.1.1, smo pa tako exam.net kot razvijalce SafeExamBrowserja obvestili o neljubi posodobitvi, ki nam otežuje izvajanje e-izpitov v letnem izpitnem obdobju.
} 


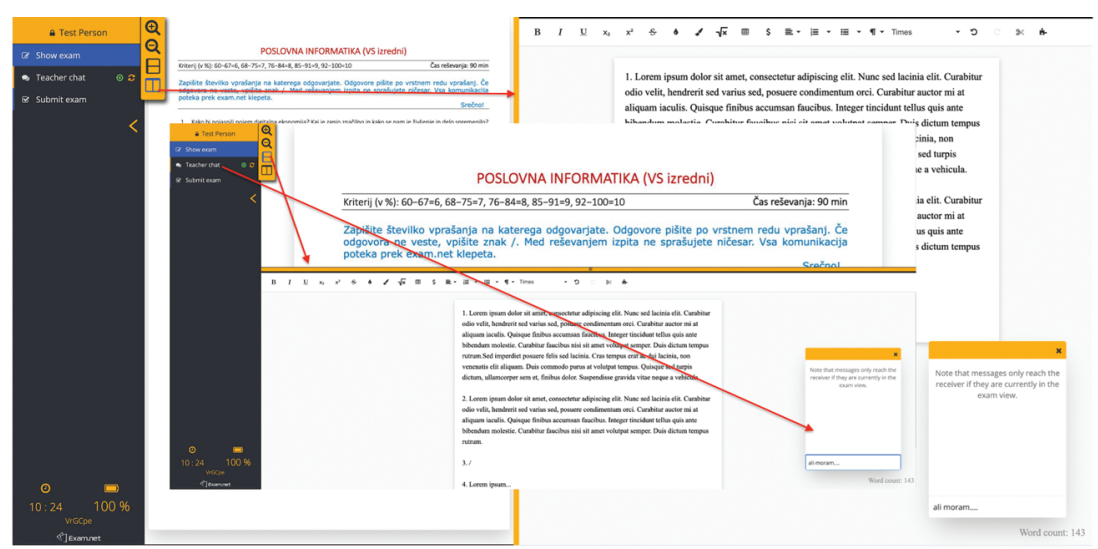

Slika 4.10 Študentski pogled na izpit v exam.net

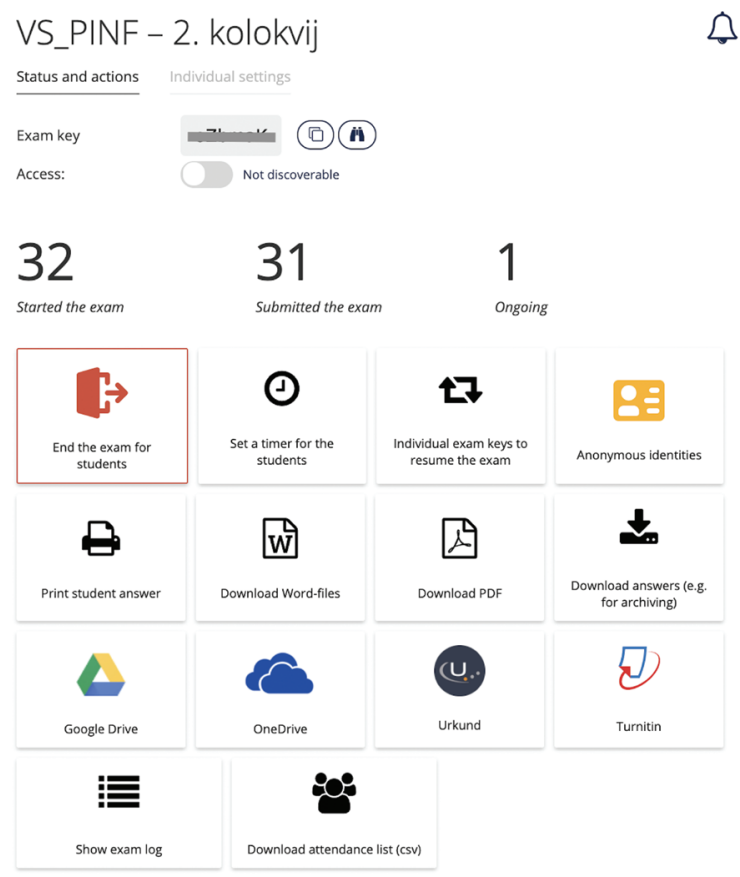

Slika 4.11

Nadzorna plošča izpita

kaciji, ki med študentom in učiteljem poteka le prek sistema exam.net. Učitelj lahko sporočila pošilja posameznemu študentu ali pa celotni skupini - npr. 10 minut pred iztekom izpita študente obvesti, da je do konca še 10 minut. Takšen način komuniciranja pri izpitih na daljavo ne moti poteka izpita, kar je v primerjavi s klasično izvedbo velika prednost. 
Ko se izpit zaključi, učitelj na svoj računalnik prenese posamezne izpitne naloge ali pa se vse izpitne naloge prenesejo v enem dokumentu P D F (slika 4.11). Ocenjevanje nalog je za učitelja enostavno, saj v dokument PDF lahko vpisuje komentarje in dosežene točke/ocene. Exam.net se lahko poveže tudi s sistemi za preverjanje plagiatorstva (Urkund in Turnitin). 


\section{Preverjanje in ocenjevanje znanja}

\subsection{Opredelitev osnovnih pojmov}

Preverjanje in ocenjevanja znanja je proces merjenja, dokumentiranja in vrednotenja spremenjenega vedenja učečih se (Simonson idr. 2011, 263). Ocenjevanje učnih dosežkov učečih se je nujni del vsakega izobraževalnega procesa (Šteh in Šarić 2016, 65). Sistematično zbiranje podatkov o doseženih učnih dosežkih (Marentič-Požarnik 200o, 260) je učitelju v pomoč pri spremljanju procesa učenja ter prilagajanju učnega procesa učečemu se. Ovrednotenje doseženih učnih rezultatov z opisnimi ali s številčnimi ocenami imenujemo ocenjevanje. MarentičPožarnikova (2000, 260) izpostavlja nujnost povezanosti ocenjevanja s preverjanjem znanja. Ocenjevanja brez preverjanja naj ne bi bilo, lahko pa izvedemo le preverjanje. Obseg in strukturo znanja lahko preverimo na začetku učne enote (diagnostično preverjanje) (str. 26), kar nam pomaga pri ugotavljanju predznanja učečih se in prilagajanju učnega procesa predznanju oziroma iskanju rešitev za zapolnitev vrzeli v njem (dodatne vsebine in gradiva). Med učnim procesom se razumevanje učnih vsebin običajno preverja neprekinjeno, neformalno ali formalno (Jarvis, Holford in Griffin 2003, 159). Neformalno pomeni, da učencem zastavimo vprašanja o določeni temi, formalno pa, da uporabimo kvize in različne naloge, povezane s temo. Preverjanje dosežkov učnega procesa med samim učnim procesom je znano kot formativno ocenjevanje, medtem ko sta preverjanje in ocenjevanje naučenega na koncu učnega procesa znana kot sumativno ocenjevanje (str. 159). Na koncu učnega procesa se znanje običajno oceni s pisnim in/ali z ustnim izpitom.

Številni avtorji (Marentič-Požarnik 200o, 563; Wiliam 2011; Jackel idr. 2017; Brown in Glover 2019) izpostavljajo pozitiven učinek povratne informacije pri preverjanju in ocenjevanju znanja na proces učenja, zaradi česar je povratna informacija nujen sestavni del vsakega preverjanja in ocenjevanja znanja ter mora biti integrirana $v$ proces učenja. Ocenjevanje tako ne sme predstavljati le zajemanja podatkov o doseganju učnih izidov, saj mora biti, med drugim, skladno z namenom učenja 
ter prek različnih (osmišljenih) aktivnosti, ki vodijo k doseganju učnih izidov, podpirati proces učenja (Brown 2019, 50). Že leta, predvsem na douniverzitetnem izobraževanju, se poudarja $\mathrm{k}$ učečemu se usmerjeno učenje, kjer je učeči se aktivno vključen v proces učenja, formativno ocenjevanje pa predstavlja ocenjevanje za učenje (angl. assessment for learning), za razliko od učenja, kjer se preverjajo in ocenjujejo le rezultati učenja (angl. assessment of learning), kar predstavlja sumativno ocenjevanje. Pozitivne učinke ocenjevanja za učenje je na osnovi številnih raziskav predstavil Wiliam (2011). Čeprav se omenjene raziskave nanašajo predvsem na mlajše učence, pa imata formativno preverjanje in ocenjevanje pomembno vlogo tudi v visokem šolstvu (Jackel idr. 2017). Slednje je razvidno tudi iz pomembnih znanstvenih revij, usmerjenih $v$ objavljanje člankov o tem področju, kot je npr. revija Assessment \& Evaluation in Higher Education, pa tudi iz monografij, kot je npr. že druga izdaja monografije o inovativnem ocenjevanju v visokem šolstvu urednic Brownove in Gloverjeve (2019). Pregled naslovov in ključnih besed objavljenih člankov v omenjeni reviji izkazuje vedno večji pomen učne analitike, ki omogoča pravočasno diagnosticiranje ovir pri napredovanju študentov in takojšnje ukrepanje. Učna analitika omogoča tudi diferenciacijo in prilagajanje učenja učečemu se (Sclater, Peasgood in Mullan 2016, 5).

\subsection{Ocenjevanje v slovenski visokošolski zakonodaji}

Pomembnost ocenjevanja $\mathrm{v}$ slovenskem visokem šolstvu je razvidna iz Zakona o visokem šolstvu (zVis) (2012), kjer so načini ocenjevanja opredeljeni kot obvezna sestavina študijskih programov prve in druge stopnje (35. člen) ter tudi študijskih programov za izpopolnjevanje (35.a člen). Način ocenjevanja v posameznih študijskih programih je razviden tudi iz evidence študijskih programov (evš) (81.d člen). Preverjanje in ocenjevanje znanja je kot obvezna sestavina študijskega programa vključeno v Merila za akreditacijo in zunanjo evalvacijo visokošolskih zavodov in študijskih programov (v nadaljevanju Merila) (2017). Merila (7. člen, 5. standard) predvidevajo preverjanje vnaprej objavljenih meril in načinov ocenjevanja, pravičnost in preglednost ocenjevanja ter uporabo različnih metod ocenjevanja. $V$ postopku akreditacije študijskega programa se preverja tudi pomoč visokošolskega zavoda učiteljem pri razvijanju znanj na področju ocenjevanja. Načini ocenjevanja morajo biti opredeljeni na način, iz katerega je razvidno, da se resnično preverja doseganje učnih izidov in kompetenc. Merila poudarjajo vlogo, ki jo imata preverjanje in ocenjevanje znanja pri sprotnem študiju ter 
spremljanju napredka študenta. Iz slednjega lahko razberemo usmeritev Meril k sprotnima (formativnima) preverjanju in ocenjevanju znanja, čemur sledi povratna informacija učitelja. V obrazcu učnega načrta, ki ga Nacionalna agencija Republike Slovenije za kakovost v visokem šolstvu (NAKVIS) predlaga na spletni strani, ${ }^{1}$ je podrobna opredelitev načinov preverjanja in ocenjevanja znanja prepuščena visokošolskemu učitelju oziroma visokošolskemu zavodu. Na U P F M je učiteljem priporočeno, da v čim večji meri vključujejo formativne načine preverjanja in ocenjevanja znanja. Sam obrazec učnega načrta omogoča vpis strukture končne ocene, ki jo lahko sestavljajo krajši in daljši pisni izdelki, javni nastopi in predstavitve študentov ter drugi načini sprotnih preverjanja in ocenjevanja znanja. Delež končnega (pisnega ali ustnega) ocenjevanja znanja naj bi ne predstavljal več kot $50 \%$ v končni oceni predmeta. Večina visokošolskih učiteljev te smernice upošteva, so pa tudi izjeme, ki sumativnemu ocenjevanju še vedno dajejo velik pomen in takšen način ocenjevanja predstavlja večinski delež ali pa se ocenjevanje pri predmetu opravi le na koncu.

\subsection{Uporaba IK T pri preverjanju in ocenjevanju znanja}

Videli smo, da je opredelitev e-učenja veliko (preveč). Naj na tem mestu izpostavimo opredelitev Ameriškega društva za usposabljanje in razvoj (American Society for Training and Development - AS T D) ter opredelitev E U, ki e-učenje (angl. e-learning) opredelita kot učenje, pri katerem se uporablja IKT, ne glede na to, ali se pedagoški postopek izvaja v klasičnih učilnicah ali na daljavo (Fee 2009, 14-15). I K T je mogoče v pedagoški proces vključiti v posameznih fazah (npr. posredovanje znanja prek e-gradiv ali komunikacija prek foruma) ali pa na daljavo izvedemo celoten pedagoški proces. Tako na daljavo izvedemo posredovanje znanja, utrjevanje pa tudi preverjanje in ocenjevanje znanja. Elektronsko podprto ocenjevanje imenujemo e-ocenjevanje (Stödberg 2012). Stödberg (2012) je analiziral članke, objavljene v treh indeksiranih revijah, Assessment \& Evaluation in Higher Education, Computers \& Education in British Journal of Educational Technology, in ugotovil, da se je zanimanje za e-ocenjevanje $\mathrm{v}$ visokem šolstvu med letoma 2004 in 2009 povečalo. Analiza objavljenih prispevkov je pokazala, da se tehnologija uporablja za formativno in za sumativno ocenjevanje. Izpostavlja pa izzive izvajanja e-ocenjevanja v praksi (Warburton $2009 \mathrm{v}$ Stödberg 2012).

\footnotetext{
${ }^{1}$ Glej https://www.nakvis.si/akreditacije-in-evalvacije-v-visokem-solstvu/enakvis/.
} 
Z uvajanjem formativnega preverjanja, ki zahteva veliko dela s popravljanjem nalog študentov, se je povečala potreba po vključevanju I K T V preverjanje in ocenjevanje znanja (Sangle, Nandurkar in Pawar 2020). V te namene lahko uporabimo različna spletna orodja pa tudi orodja, integrirana v sisteme za upravljanje učenja (L M S), kot je Moodle. Vsa ta orodja lajšajo delo učitelja pri ocenjevanju nalog, saj se naloge ocenjujejo samodejno, učeči se pa takoj prejme povratne informacije o pravilnosti/nepravilnosti rešene naloge.

Uporaba IKT za preverjanje in ocenjevanje znanja se je razširila z množičnimi odprtimi spletnimi tečaji (MOOC), kjer je uporaba IKT nujna že zaradi velikega števila študentov. Izkušnje tečajev M O o c so pokazale predvsem prednosti medvrstniškega ocenjevanja, ki se uporablja tudi v klasično ali na kombinirani način izvedenih predmetih in pozitivno vpliva na celoten učni proces (Florjančič 2018, 94-95).

Pri izvedbi klasično izvedenih predmetov pa tudi pri kombinirani obliki izvedbe (angl. blended learning) učitelji za preverjanje in ocenjevanja znanja uporabljajo različne tehnologije ter orodja. Pri uporabi spletnih sistemov za upravljanja učenja (sistemi LMS) se večinoma uporabljajo testi ali kvizi, saj omogočajo pripravo širokega nabora različnih vprašanj, kar tvori zbirko (bazo) vprašanj. V zbirki vprašanj se vprašanja razdelijo $\mathrm{v}$ teme, znotraj teh pa še $\mathrm{v}$ tipe (skupine) vprašanj, iz katerih se potem, glede na nastavitve, oblikuje testna (ali izpitna) pola z različnimi vprašanji. Nastavitve takšnih testov omogočajo, da se vprašanja pa tudi posamezni možni odgovori poljubno premešajo. Vnaprej pripravljeni komentarji na pravilne (nepravilne) odgovore dajejo učečemu se takojšnjo povratno informacijo, samodejno ocenjeni odgovori pa učitelju olajšajo delo. Uporaba odprtih (esejističnih) vprašanj še vedno zahteva pregled in ročno ocenjevanje. Enako velja za tedenske naloge, ki številne učitelje odvračajo od svoje intenzivnejše uporabe. Tako se delo študentov v praksi pogosto ocenjuje $\mathrm{z}$ opravljeno/neopravljeno nalogo in brez resnične povratne informacije.

Kvizi (testi) znanja v sistemih za upravljanje učenja (npr. v Moodlu) se pogosto uporabljajo za sprotno preverjanje znanja študentov, saj slednjim kviz/test lahko pripravimo vsak teden ali ob zaključku teme. Študentje lahko test rešijo le enkrat, lahko pa tudi večkrat, če je namenjen utrjevanju znanja. Na takšen način jih spodbujamo k sprotnemu delu in jim tako pomagamo pri študiju. Nekateri učitelji test uporabijo za preverjanje znanja pred izpitom ali pa je uspešno opravljen test predpogoj za pristop k izpitu. Kadar se z e-izpitom preverja znanje na daljavo, po- 
seben izziv predstavlja nadzor nad izpitom - zato se e-izpiti običajno izvajajo kar v računalniški učilnici pod nadzorom učitelja.

$\mathrm{Na}$ trgu je mogoče najti številne t.i. izpitne platforme, na primer exam.net, ${ }^{2}$ Inspera ${ }^{3}$ ali T A O, ${ }^{4}$ če omenimo le evropske platforme, ki so skladne s splošno uredbo E U o varstvu podatkov (G DPR). Platforme so bile razvite za olajšanje opravljanja izpitov $v$ fizičnih učilnicah pod nadzorom učitelja. Vprašanje nadzora nad izpitom (angl. proctoring) predstavlja največji izziv za vse tradicionalne univerze, ki so preverjanje in ocenjevanje znanja zaradi »lockdowna« uvedle v obliki na daljavo.

\subsection{Izzivi izvedbe izpitov na daljavo}

Priložnosti in izzivi selitve izobraževalne dejavnosti na splet so predmet številnih študij, ki so povezane predvsem $\mathrm{z}$ mobilnostjo, internacionalizacijo in izzivi, s katerimi se soočajo visokošolske ustanove, učitelji in študenti. Mednarodno združenje univerz (IAU) je zbralo podatke 424 visokošolskih zavodov v 190 državah (OE CD 2020). Več kot $90 \%$ anketiranih ustanov je poučevanje $\mathrm{v}$ učilnicah nadomestilo $\mathrm{z}$ oddaljenim poučevanjem. Nekateri ( $7 \%$ ) so celo odpovedali poučevanje oziroma so pedagoški proces prestavili na kasneje. Zbrani podatki niso reprezentativni, so pa dobra podlaga za razprave in nadaljnje raziskovanje. Prenos študijske dejavnosti na splet ne vključuje le nadomestitve kontaktnih ur $z$ videokonferencami ali drugimi načini poučevanja. $S$ selitvijo pedagoškega procesa na splet so se odprla vprašanja o preverjanju in ocenjevanju znanja ter zagotavljanju študentom možnosti napredovanja na njihovi študijski poti.

Opravljanje izpitov na daljavo odpira več vprašanj (O E CD 2020):

- Kako onemogočiti goljufanje na izpitih ter plagiate pri nalogah?

- Kako izvesti preverjanje in ocenjevanje praktičnih veščin na daljavo?

- Kako zagotoviti pravičnost? Pri klasičnem izpitu študentje izpit opravljajo hkrati, v istem prostoru in pod enakimi pogoji, česar doma ni mogoče zagotoviti. Odpirajo se tudi vprašanja dostopa do interneta, hitrosti povezave in značilnosti strojne opreme (npr. velikost zaslona, kamera ipd.).

\footnotetext{
${ }^{2}$ Glej https://exam.net/.

${ }^{3}$ Glej https://www.inspera.com/.

${ }^{4}$ Glej https://www.taotesting.com/ - platformo za testiranje znanja otrok uporabljajo v Franciji.
} 
Slika $5 \cdot 1$

Raziskovalni okvir

\begin{tabular}{|c|}
\hline 1 - Izzivi ocenjevanja na daljavo (OECD 2020) \\
\hline $\begin{array}{l}\text { - Goljufanje in plagiat } \\
\text { - Preverjanje in ocenjevanje praktičnih veščin } \\
\text { - Pravičnost } \\
\text {-Tehnične težave }\end{array}$ \\
\hline 2 - Uvedba izpitov na daljavo na UP FM \\
\hline 3 - Raziskava - raziskovalna vprašanja \\
\hline $\begin{array}{l}\text { - RV1: IT rešitve, ki se uporabljajo za izpite na daljavo } \\
\text { - RV2: Nevarnosti goljufanja (nadzor nad potekom izpita) } \\
\text { - RV3: Tehnični izzivi in IT podpora } \\
\text { - RV4: Vpliv »lockdowna« na poučevanje }\end{array}$ \\
\hline 4 - E-anketa - UČitelji UP FM (N=52) \\
\hline
\end{tabular}

- Kako zmanjšati tveganje za tehnične težave, ki bi onemogočile izvedbo/opravljanje izpita?

Na reševanje izzivov, povezanih z izpiti na daljavo, so se visokošolske institucije odzvale na različne načine (OE C D 2020). Nekatere ustanove so izpitne roke premaknile na kasnejša obdobja in študentom ponudile možnost napredovanja v višji letnik brez opravljenih izpitov. Odprla so se tudi vprašanja, kaj z izpiti, ki predstavljajo zaključek šolanja in/ali je opravljanje teh izpitov povezano $\mathrm{z}$ nadaljevanjem študija na višji ravni. Podobne razprave so se odvijale tudi v Sloveniji. V Sloveniji so tako študentje lahko ohranili status študenta kljub neizpolnjenim pogojem za napredovanje po študijskem programu. Izvedle pa so se tudi številne diskusije o maturi, ki na eni strani predstavlja zaključek šolanja, na drugi strani pa rezultati mature predstavljajo vstop v programe $\mathrm{z}$ omejitvijo vpisa. Pa ne samo za tekoče študijsko leto, tudi za naprej, kar odpira vprašanja izenačenosti pogojev za vpis za vse generacije.

Vprašanja O E CD (2020) smo uporabili pri pripravi smernic za opravljanje izpitov na daljavo in za raziskavo o odzivih učiteljev (slika 5.1).

\subsection{Metodologija in raziskovalna vprašanja}

$\mathrm{Z}$ izpiti na daljavo smo se srečali že aprila 2020, ob zaključku prvega kvartala, v prvem valu epidemije covida-19. Izpiti so se na daljavo izvajali tudi ob zaključku 3. in delno 4. kvartala. Tako smo že junija 2020 izvedli raziskavo o tem, kako se učitelji spopadajo z e-izpiti, kakšni so njihovi izzivi in kakšno podporo bi potrebovali oziroma pričakovali. Raziskavo smo, nekoliko dopolnjeno, ponovili še konec marca 2021, saj je pedagoški proces spomladi 2021 še vedno potekal na daljavo. $Z$ raziskavo smo želeli pridobiti odgovore na naslednja raziskovalna vprašanja: 
- RV1: Kakšne IT-rešitve so bile uporabljene pri izvedbi izpitov na daljavo?

- RV 2: Ali so učitelji obvladovali poskuse goljufanja oziroma kako so izvajali nadzor nad izpitom?

- RV3: Ali so se učitelji soočali s kakšnimi tehničnimi težavami ter ali bi v prihodnosti potrebovali kakršno koli pomoč in podporo?

- RV4: Kako je zaprtje univerze vplivalo na poučevanje in učitelje?

Kot omenjeno smo podatke zbrali v dveh delih - junija 2020, po koncu prvega vala epidemije, in v tretjem valu epidemije, konec marca 2021.

$\mathrm{V}$ prvem delu so bili podatki zbrani s pomočjo odprtokodnega orodja $1 \mathrm{KA} .{ }^{5}$ Učitelje smo $\mathrm{k}$ izpolnitvi ankete povabili prek elektronskega seznama učiteljev UP F M 26. junija 2020. Druga raziskava je temeljila na spletnem vprašalniku, pripravljenim z Googlovimi obrazci. Učitelji so bili povabljeni k izpolnjevanju vprašalnika 31. marca in 2. aprila 2021.

\subsection{Rezultati raziskave}

Na U P F M je v pedagoški proces v celoti ali delno vključenih 52 visokošolskih učiteljev in sodelavcev. Zbiranje podatkov je potekalo prek dveh e-vprašalnikov. Oba sta bila anonimna; s prvim vprašalnikom smo prejeli 27 odgovorov (51,9-odstotni odziv), z drugim pa 29 odgovorov (55,8odstotni odziv).

Anketiranci, ki so odgovorili na prvi vprašalnik, so imeli od 5 do 32 let pedagoške prakse; povprečni anketiranec je imel 15,3 let pedagoških izkušenj (SD = 6,7 let). Anketiranci menijo, da so vsaj povprečni (52\%), če ne celo dobri $(36 \%)$ ali odlični $(8 \%)$ uporabniki IKT. Le en anketiranec (4\%) se izogiba uporabi I K T v pedagoški praksi. V drugem delu raziskave le trije anketiranci (10,3\%) niso izvedli izpitov na daljavo. Med anketiranci v drugem delu raziskave jih $68,9 \%$ prihaja $z$ izkušnjami izvedbe izpita na daljavo iz prvega vala epidemije (eden od njih je izpite izvedel le za tuje študente, ki študirajo na U P F M), 10,3\% pa se jih je $\mathrm{z}$ izpiti na daljavo prvič srečalo $\mathrm{v}$ drugem valu epidemije ( $\mathrm{v}$ študijskem letu 2020/2021). V drugem vprašalniku nismo ponovili vprašanj o pedagoških izkušnjah in I K T-spretnostih učiteljev, saj smo anketirali isto populacijo.

Skoraj vsi učitelji (97\%), ki so odgovorili na prvi vprašalnik, so izpite in/ali kolokvije v kvartalu izvajali na daljavo. V več kot polovici prime-

\footnotetext{
${ }^{5}$ Glej https://1ka.arnes.si//index.php.
} 
Preglednica 5.1 Tehnologija, uporabljena pri izvedbi izpitov na daljavo

\begin{tabular}{lrr}
\hline Tehnologija & 2020 & 2021 \\
\hline Zoom - ustni izpit & 10 & 7 \\
Moodle - Kviz & 8 & 5 \\
Moodle - Naloga & 5 & 1 \\
exam.net & 5 & 11 \\
\hline
\end{tabular}

OP ОМвE Vodstotkih.

$\operatorname{rov}(64 \%$ leta $2020,66,7 \%$ leta 2021) so bili izpiti na daljavo enaki klasičnim izpitom, medtem ko je $36 \%$ (leta 2020) oziroma 25,0\% (leta 2021) vprašanih vsebino izpita prilagodilo načinu opravljanja izpitov.

Učitelji so uporabljali različne izpitne tehnologije (RV1). Leta 2020 se jih je največ odločilo za ustni izpit prek videokonferenčnega sistema ali so izpit izvedli prek Moodlovega kviza; leto kasneje pa se je najpogosteje uporabljala platforma exam.net, in to ne samo za ročno napisane izpite (preglednica 5.1).

Moodlov kviz se uporablja za vmesno in zaključno preverjanje ter ocenjevanja znanja. Od leta 2020 do leta 2021 je bil pomemben prehod z Moodlovih nalog na Moodlov kviz (preglednica 5.1). Razlike so bile ugotovljene tudi v strukturi kviza (slika 5.2). Leta 2021 so se učitelji, ki so kot platformo za eseje uporabili Moodlov kviz, preselili na platformo exam.net (povečan delež exam.net in zmanjšan delež Moodlovega kviza od leta 2020 do 2021, predstavljen v preglednici 5.1) ali pa so začeli uporabljati različne vrste vprašanj (slika 5.2). V raziskavo so bile vključene tri najpogosteje uporabljene vrste vprašanj na U P F M - računske naloge (študent vpiše izračunani rezultat), vprašanja z več možnostmi (eden ali več pravilnih odgovorov) in esejistična vprašanja.

Pri opravljanju izpitov na daljavo je, kot je izpostavila že raziskava OECD (2020), največji izziv povezan s preprečevanjem poskusov goljufanja oziroma kako na daljavo vzpostaviti nadzor nad opravljanjem izpita. Del nadzora omogoča že uporaba same izpitne tehnologije. Tako na primer exam.net, če študent piše odgovore $\mathrm{v}$ sistem, omogoča sledenje študentovim odgovorom, Moodlov kviz pa tega ne omogoča. Običajno pa se nadzor izvaja prek sočasne povezanosti učitelja in študentov $\mathrm{v}$ videokonferenci. Na U P F M smo v ta namen uporabili videokonferenčni sistem zooM. Za preprečitev oziroma za minimiziranje možnosti goljufanja učitelji pogosto zahtevajo dvojno prijavo - eno prek računalnika, na katerem poteka izpit, in drugo prek mobilne naprave. Leta 2020 je izpit z zOOM-om podprlo $84 \%$ anketirancev, leta 2021 pa se je upo- 


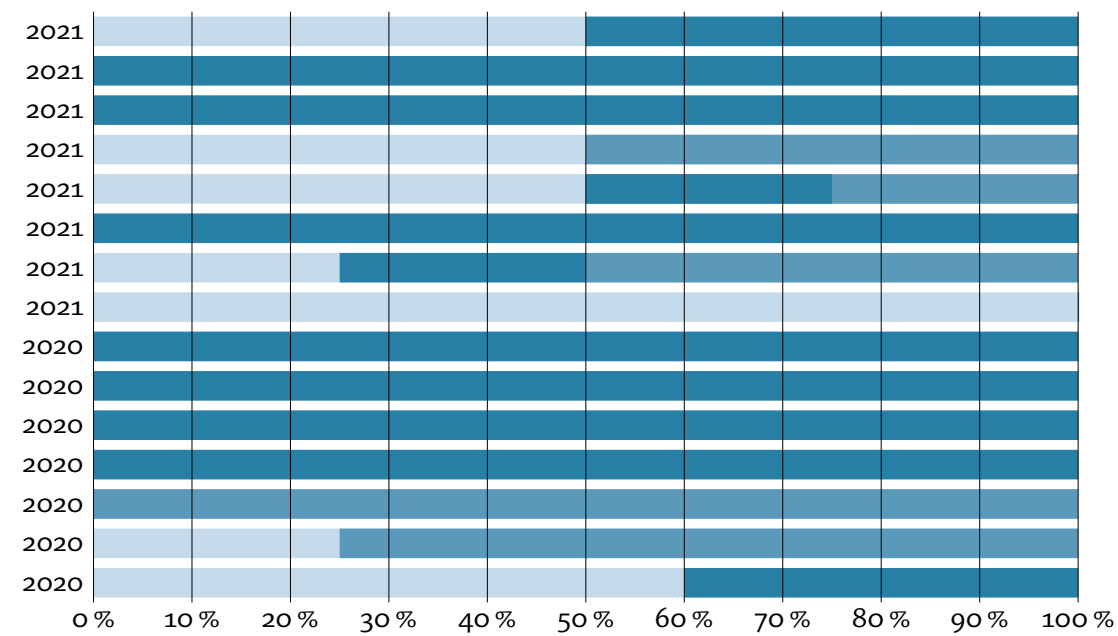

Svetlo - vprašanja z več možnostmi, srednje - esejistična vprašanja, temno - računske naloge

Slika 5.2 Struktura Moodlovih izpitov

rabljal zo om ali MS Teams. Študentje so imeli med izpitom vključeno kamero in zvok, navidezno ozadje pa se je izklopilo, tako da je bil viden prostor študenta. Manj kot tretjina $(28 \%)$ leta 2020 in $40 \%$ leta 2021 jih je zahtevalo drugo prijavo študenta s pametnega telefona. Leta 2021 so štirje anketirani učitelji (14,3\%) zahtevali, da so študentje potek izpita snemali s pametnimi telefoni. Posnetek je bil uporabljen za odpravo kakršnega koli suma goljufanja. Vsak študent je posnetek delil z učiteljem in tako odpravil vse dvome o poskusu goljufanja - izpit je reševal prijavljen študent brez pomoči tretje osebe in pri izpitu niso bili uporabljeni nedovoljeni viri. Študentje so svoje posnetke izbrisali takoj, ko je učitelj v študentski informacijski sistem vpisal ocene izpita. $\mathrm{V}$ enem primeru je bil ta posnetek uporabljen za identifikacijo študenta (študentje so se na koncu posnetka posneli v obraz in hkrati pokazali osebni dokument). Dobra tretjina učiteljev (37,5\%) je študente identificirala posamično (študente so $\mathrm{v}$ izpitno sobo spuščali posamično in jih pri tem identificirali), tretjina (33,3\%) pa je identifikacijo opravila pred celotno skupino študentov. Petina učiteljev $(21,4 \%)$ vse svoje študente pozna po imenu in priimku, zato dodatna identifikacija ni bila potrebna.

Ustni izpiti so bili opravljeni prek sistema za videokonference, večinoma je izpit potekal s posameznim študentom (63,6\% ustnih izpitov) ali v manjši skupini (27,3\%). Samo v enem primeru je imel učitelj vse študente sočasno $\mathrm{v}$ virtualni izpitni sobi. 
Preglednica 5.2 Izzivi izpitov na daljavo

\begin{tabular}{lrr}
\hline Odgovori & 2020 & 2021 \\
\hline Skrb glede možnosti goljufanja & 1 & 4 \\
Nadzor nad izvedbo izpita & 5 & 1 \\
Pogoji doma/v študentski sobi in nevarnost vdora v zasebnost & 2 & 1 \\
Tehnične težave & 8 & 1 \\
Število študentov & 3 & 2 \\
Poraba časa za izvedbo izpita & 1 & 2 \\
Brez izzivov & 7 & 17 \\
\hline
\end{tabular}

Iz analize zbranih podatkov lahko ugotovimo, da so učitelji storili vse, da so možnosti goljufanja zmanjšali na najmanjšo možno mero (RV2).

Odgovore na RV3 smo poiskali z analizo ogovorov na odprta vprašanja. Besedilo odgovorov je razvrščeno $\mathrm{v}$ kategorije, predstavljene $\mathrm{v}$ preglednici 5.2. Učitelji so imeli leta 2021 manj tehničnih težav kot leta 2020; anketirani učitelji so pohvalili vso pomoč, ki so jim jo zagotovili za delo z I T bolj usposobljeni kolegi in podpora e-izobraževanja na fakulteti. $V$ pomoč so bile tudi številne delavnice in posnetki delavnic ter videovodiči, ki so nastali med prvim valom epidemije. Anketiranci so pohvalili možnosti izmenjave dobrih praks kolegov, kar jim je pomagalo pri intenzivnejši rabi I K T. Analiza podatkov je pokazala, da so se zmanjšale tehnične težave, se pa povečuje zaskrbljenost zaradi možnosti goljufanja. V prvem valu epidemije je način opravljanja izpitov predstavljal novost tudi za študente, ki so svojo pozornost in energijo usmerili $\mathrm{v}$ pripravo na izpit in uporabo tehnologije. $\mathrm{Na}$ koncu vala so študentje izpitna okolja in tehnologijo spoznali, postali so suverenejši pri njeni uporabi in začeli razmišljati tudi o možnostih goljufanja. Povečana zaskrbljenost anketirancev je zato več kot razumljiva.

Anketiranci izpostavljajo težave, povezane s številom študentov na izpitu (preglednica 5.2), saj je spremljanje večjega števila v isti videokonferenčni sobi zahtevno. V raziskavi iz leta 2020 učitelji predlagajo, da skupine ne bi smele biti večje od 30 študentov. Učitelji so poročali o poskusih goljufanja - pri ustnem izpitu branje $z$ zaslona, pri pisnih izpitih pa so študentje poskušali kopirati iz zapiskov. Zato se učitelji že zavedajo, da bo izpitna vprašanja pri izpitih na daljavo potrebno zastaviti na način, da bo odgovor zahteval poglobljen razmislek in da ga ne bo mogoče zlahka priklicati.

OE CD (2020) je izpostavila izziv enakih študijskih pogojev doma. Podobne izzive so zaznali tudi učitelji UP F M, saj so izpostavili motnje v 
Preglednica 5.3 Izpiti na daljavo v prihodnje (2020, $n=24)$

\begin{tabular}{lr}
\hline Trditev & Število odgovorov \\
\hline Izpit na daljavo, le če ne bo druge možnosti & 20 \\
Sumativno ocenjevanje nadomestili s formativnim ocenjevanjem & 1 \\
Bi izvajali e-izpite v računalniški učilnic (nadzor učitelja). & 3 \\
\hline
\end{tabular}

domačem okolju - od tega, da so študentje $\mathrm{v}$ študentskem domu, kjer niso sami, do tega, da so doma drugi družinski člani. Se je pa delež teh težav od leta 2020 do leta 2021 zmanjšal (preglednica 5.2). Nekatere tehnične težave so bile odpravljene $\mathrm{z}$ razpisom dodatnih izpitnih rokov. Priprava in opravljanje izpitov sta bila za učitelje zahtevna. Soočali so se s pomanjkanjem opreme, težavo pa je povzročalo tudi omejeno število z O OM-ovih licenc v letu 2020 (t. i. osnovna licenca omogoča le do 40minutne sestanke). Zaznane so bile težave s S E B-om, zlasti pri študentih, ki niso upoštevali navodil in niso namestili pravilne različice SE B-a (preglednica 5.2 - tehnične težave). Leta 2021 so učitelji prejeli šolske prenosne računalnike, univerza pa je kupila zooM-ove licence za vse zaposlene in študente, zato tega leta težave $z$ opremo niso bile več izpostavljene. Leta 2020 so učitelji opravljanje izpitov na daljavo videli bolj kot izhod v sili (preglednica 5.3), vendar pa sta dva anketiranca pod »drugo« zapisala, da bosta z e-izpiti nadaljevala.

Leta 2021 je bilo v raziskavo vključeno podobno vprašanje. Kot je razvidno iz preglednice 5.4, e-izpiti med anketiranimi učitelji še vedno niso priljubljeni. Toda če primerjamo podatke med letoma 2020 (preglednica 5.3) in 2021 (preglednica 5.4), vidimo, da bi več učiteljev želelo nadaljevati z e-izpiti - na daljavo ali v računalniški učilnici pod nadzorom učitelja. Dobrodošlo je, da so nekateri učitelji razvili druge strategije ocenjevanja ali nadomeščajo sumativno (končno) ocenjevanje $s$ formativnim (sprotnim) preverjanjem in ocenjevanjem znanja (preglednica 5.4).

Učitelji na UP F M po spletu poučujejo od marca 2020, in kot kaže, bomo, ne glede na ugodnejšo epidemiološko sliko, študijsko leto 2020/ 2021 končali na takšen način. Zanimalo nas je, s kakšnimi spremembami so se soočili učitelji po letu poučevanja na daljavo (RV4). Anketirancem smo ponudili trditve, predstavljene v preglednici 5.5 , in jih prosili, da označijo strinjanje/nestrinjanje s trditvijo na štiristopenjski lestvici ( 1 in 2 predstavlja nestrinjanje, 3 in 4 strinjanje).

Povprečne vrednosti dogovorov $\mathrm{z}$ izjavami, predstavljenimi $\mathrm{v}$ preglednici 5.5 , so pokazale, da so učitelji med epidemijo izboljšali I KT- 
Preglednica 5.4 Izpiti v prihodnje (2021, $n=26)$

\begin{tabular}{lr}
\hline Trditev & Število odgovorov \\
\hline Izvedli e-izpit, vendar ga v prihodnje ne želijo izvajati & 10 \\
Želijo nadaljevati z e-izpiti na daljavo & 5 \\
E-izpitov niso izvajali, zato so izpitne obveznosti nadomestili z drugimi & 5 \\
aktivnostmi študentov & 4 \\
Izvedli bi e-izpit v računalniški učilnici & 1 \\
Z e-izpiti nimajo težav, vendar so razvili drugačne metode preverjanja in & \\
ocenjevanja znanja & M \\
Izvedli so ustne izpite, ki bi jih želeli izvajati tudi v prihodnje & 3,7 \\
\hline & 3,5 \\
Preglednica 5.5 Spremembe po letu dni poučevanja na daljavo (2021, $n=29)$ & \\
\hline Trditev & 3,3 \\
\hline Izboljšali ste svoje veščine uporabe I K v pedagoškem procesu & 3,0 \\
Izboljšali ste svoje veščine uporabe I K T na splošno & 2,9 \\
Uvedli ste sodobnejše metode poučevanja & 2,9 \\
Pri poučevanju na daljavo ste postali bolj suvereni & 2,8 \\
Predmet ste vsebinsko prenovili & \\
Takšen način dela vam je bil všeč & 2,6 \\
Imeli ste občutek, da morate študentom ponuditi več razlage & 2,6 \\
kot pri klasični izvedbi & 2,3 \\
Od študentov ste zahtevali več samostojnega dela & 1,8 \\
S takšnim načinom dela bi nadaljevali & 1,4 \\
Presenetili ste sami sebe & \\
Izvedbo predmeta ste v drugem vali epidemije poenostavili & \\
Pri delu na daljavo ste bili izgubljeni & \\
\hline
\end{tabular}

spretnosti pri poučevanju $(M=3,7)$ in svoje I K T-spretnosti na splošno $(M=3,5)$. Zaradi dobro organizirane podpore drugih učiteljev se pri delu na daljavo niso počutili izgubljene $(M=1,4)$. Vse povprečne vrednosti do 2,0 kažejo nestrinjanje s predstavljenimi trditvami, povprečne vrednosti 3,o in več pa strinjanje.

\subsection{Povzetek}

Nepričakovano razglašena epidemija covida-19 in zaprtje univerz sta vse tradicionalne visokošolske organizacije postavila pred številne izzive. Če je bil prenos predavanj s pomočjo videokonferenčnih sistemov relativno nezahteven, pa smo se $z$ izzivi soočili, ko je nastopilo obdobje preverjanja in ocenjevanja znanja. Smernice in usmeritve preverjanja ter ocenjevanja znanja na daljavo smo pripravili na osnovi ugotovi- 
tev raziskave OECD (2020). Smernice smo preverili v praksi, nato pa, za razumevanje izzivov, s katerimi so se srečali učitelji v izpitnem obdobju, opravili raziskavo. Ta je temeljila na podatkih, zbranih z dvema e-vprašalnikoma. Anketiranje je bilo anonimno in izvedeno v dveh delih, junija 2020 in marca/aprila 2021. V obeh terminih je anketiranje potekalo na populaciji učiteljev U P F M, tisti članici U P, ki ima z uporabo IKT v pedagoškem procesu največ prakse in jo tudi najaktivneje uporablja. Anketirani učitelji so bili k izpolnitvi ankete povabljeni prek e-poštnega seznama učiteljev. Na prvo anketo smo dobili 51,9-odstotni odziv, na drugo pa 55,8-odstotnega.

Učitelji U P F M so poučevanje na daljavo prestali brez večjih težav, $\mathrm{k}$ čemur so pripomogle dolgoletne izkušnje z e-učilnico in izvedbo dela študijskega procesa na daljavo. Kljub temu so se v kvartarnem in kasneje v rednem izpitnem obdobju pojavili številni izzivi.

V prvem valu epidemije, spomladi 2020, so številni učitelji raje zamenjali pisni izpit z ustnim izpitom prek videokonference, saj je bila takšna izvedba enostavnejša. Učitelji, ki so za preverjanje znanja že prej uporabljali Moodlov kviz, so tega uporabili tudi za izvedbo e-izpitov - posebej tisti, ki so imeli zgrajeno obsežno zbirko vprašanj. V tem primeru je bila uporaba Moodlovega kviza smiselna in vsaj z vidika priprave »izpitne« pole najracionalnejša in najučinkovitejša. V letu 2021 so učitelji postali suverenejši pri svojem spletnem poučevanju (preglednica 5.5), tako da je skoraj polovica vprašanih izpite izvajala prek švedske izpitne platforme exam.net. $Z$ njo so učitelji nadomeščali odprta vprašanja iz Moodlovega kviza (slika 5.2); uporabili pa so jo tudi za izvedbo izpitov, pri katerih študentje odgovore pišejo na roko (npr. matematika, statistika, računovodstvo) in se je izvedba izpitov na daljavo v letu 2020 zdela neizvedljiva. Na U P F M sta bili vodilni tehnologiji za izvedbo pisnih izpitov tako Moodlov kviz in platforma exam.net, za ustne izpite pa videokonferenčni sistem ZOOM (RV1).

Leta 2020 so se učitelji obremenjevali z vprašanjem, kako zagotoviti nadzor nad izpitom, da bi izpiti na daljavo ohranili kredibilnost in verodostojnost. Skrbno izdelani vzorci izpitnih protokolov, ki jih je vsak učitelj prilagodil svojim potrebam, so to skrb zmanjšali (preglednica 5.2). Se je pa v letu 2021 povečala skrb glede možnosti goljufanja (RV2). Če so bili študentje $\mathrm{v}$ prvem valu bolj osredotočeni na pravilno uporabo izpitne tehnologije in pripravo na izpit, so v tretjem valu več truda namenili iskanju možnosti, kako izpit opraviti na lažji način. Seveda so učitelji naredili vse, da bi možnosti goljufanja zmanjšali na minimum. 
Res pa je, da so poskusi goljufanja prisotni tudi pri klasičnem izpitu. Učitelji so poskrbeli za prepoznavo študentov (študente so poznali ali pa so se le-ti morali identificirati z osebnim dokumentom - študentsko izkaznico) ter $z$ izpitnim protokolom možnosti goljufanja zelo omejili (S E B, nadzor prek zo oM-a, snemanje poteka izpitov ipd.).

Izvedba e-izpitov je za študente, pa tudi za učitelje, stresna, saj zahteva določene tehnološke rešitve in sposobnost njihove uporabe. Učitelji so opozorili na velikost skupine, ki jo je možno ustrezno nadzorovati, čeprav so nekateri dela z I T bolj vešči učitelji uspeli nadzorovati tudi velike skupine študentov. K temu so pripomogli dodatna prijava v zo o M, snemanje poteka izpita ter deljenje posnetka $\mathrm{z}$ učiteljem. Učitelji so $\mathrm{v}$ letu 2021, tudi po zaslugi pridobitve novih računalnikov ter podpore na fakulteti, poročali o manj tehničnih težavah kot v letu 2020 (preglednica 5.2) ( $\mathrm{RV}$ 3). V t.i. epidemiološkem letu poučevanja na daljavo so pridobili nova znanja; izboljšali so svoje spretnosti uporabe I K T na splošno $(M=3,5)$ in v pedagoški praksi $(M=3,7)$ (preglednica 5.5). In kar je zelo pozitivno, uvedli so sodobne metode poučevanja $(M=3,3)$. Postali so tudi suverenejši v poučevanju, kar se kaže v že omenjenem zmanjšanju tehničnih težav.

E-izpiti so seveda nujno zlo, ki jih bodo učitelji izvajali le, če bo to potrebno, se je pa naklonjenost e-izpitom, $\mathrm{v}$ obliki na daljavo ali v računalniški učilnici pod nazorom učitelja od leta 2020 do 2021 povečala (preglednici 5.3 in 5.4), kar je dobra osnova za digitalizacijo fakultete. Izvedba e-izpita namreč omogoča številne prednosti. Naj izpostavimo berljivost odgovorov na izpitna vprašanja in prihranek papirja. Pogosto se dogaja, da učitelj glede na prijavo natisne predvideno število izpitnih pol, študentje pa se izpita potem ne udeležijo. Kot vidimo, sta uvedba in izvedba e-izpitov izziv za učitelje pa tudi za fakulteto.

Rezultati raziskave, opravljene na UP FM - kljub temu, da je na anketo odgovorila več kot polovica trenutno zaposlenih učiteljev - niso primerni za posploševanje na celotno U P ali širši slovenski visokošolski prostor. Fakulteta ima namreč svoje značilnosti in učitelji določene izkušnje. So pa te izkušnje zanimive, rezultati ankete pa uporabni pri soočanju s podobnimi situacijami ali pa pri digitalizaciji visokošolskega zavoda. 


\section{Evalvacija izvedb predmetov s področja poslovne informatike}

V nadaljevanju bomo predstavili izvedbo obveznih predmetov s področja poslovne informatike na dodiplomskem univerzitetnem (UN) in visokošolskem strokovnem (V s) študijskem programu Management ter evalvacijo izvedb v študijskih letih 2019/2020 in 2020/2021, ko se je pedagoška delavnost preselila na splet. Oba študijska programa sta bila spremenjena; v študijskem letu 2019/2020 smo vpisali prvo generacijo študentov. Študijski program označujemo s kratico in letom vpisa prve generacije študentov (V S 2019 in UN 2019 oziroma kar VS/UN 2019, ko mislimo na oba študijska programa). Tako prejšnji študijski program označujemo VS 2013 oziroma UN 2013, kar pomeni, da je bila prva generacija študentov vpisana v študijskem letu 2013/2014. Po šestih letih izvajanja obeh študijskih programov se je pojavila potreba po prenovi; prenovili smo vsebine pa tudi strukturo obeh študijskih programov.

V prejšnjih dveh študijskih programih (VS/UN 2013) je bil predmet Poslovna informatika obvezni predmet 1. letnika. Na osnovi anketiranja študentov in diplomantov ter prepoznanih potreb družbe po veščinah uporabe sodobnih tehnologij smo predmet razdelili na dva dela. V prvem študentje najprej razširijo znanja uporabe IKT, predvsem spletnih in pisarniških orodij. Ta del smo združili z vsebinami, ki so jih študentje spoznali že prej, ob vstopu na fakulteto - kaj pomeni biti študent, kako študirati, poiskati literaturo, uporabljati znanstveni aparat ipd. -, zato smo predmet poimenovali Študijski in IKT praktikum. Predmet smo ovrednotili s tremi kreditnimi točkami (K T); vsebine študijskega praktikuma so ovrednotene $\mathrm{z}$ eno K T, I K T praktikuma pa z dvema KT.

Drugi del vsebin poslovne informatike smo oblikovali v šest $\mathrm{K} T$ vreden istoimenski predmet in jih, na obeh študijskih programih, premaknili v 2. letnik, ko študentje že pridobijo nekatera temeljna znanja s področja poslovnih ved. Predmet Poslovna informatika je obvezni predmet dodiplomskega visokošolskega (V S) in univerzitetnega (U N) študijskega programa Management. 
Slika 6.1

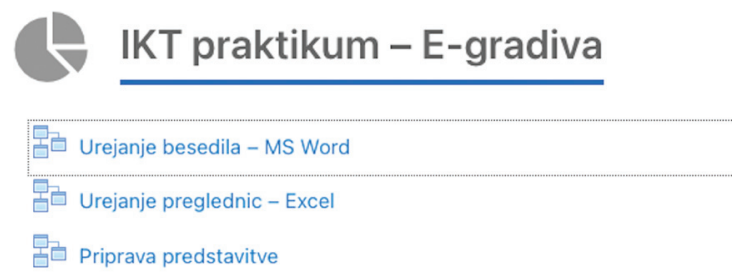

Študijska gradiva

\subsection{K T praktikum 2019/2020}

\section{Izvedba predmeta pred epidemijo}

V študijskem letu 2019/2020 smo predmet Študijski in I K T praktikum izvedli prvič, in sicer smo ga na univerzitetnem študijskem programu izvedli v 1. kvartalu, na visokošolskem strokovnem študijskem programu pa je bila izvedba IK T praktikuma (Študijski praktikum se je izvedel v 1. kvartalu), zaradi prostorskih težav, ${ }^{1}$ prenesena v 3. kvartal. Po treh tednih dela $v$ klasični predavalnici se je izvedba predmeta zaradi epidemije prenesla na splet.

Predmet je bil že od začetka zasnovan po načelih obrnjenega učenja (angl. flipped learning), kar pomeni, da so študentje gradiva prejeli vnaprej (slika 6.1), jih doma preštudirali, v šoli pa vsebine ponovili in utrdili. Snov so še dodatno utrdili s pomočjo tedenske domače naloge.

E-gradiva smo pripravili s pomočjo Moodlove lekcije, ki smo jo dopolnili z interaktivnimi videoposnetki. Študentje so prek lekcije prenesli ali po navodilih izdelali dokument/preglednico in dokument uredili ali dopolnili skladno z navodili v lekciji. Nalogi je sledil video prikaz rešitve (slika 6.2). Lekcija študentu omogoča sledenje napredku (odstotni delež zaključene lekcije). Vsebine v njej so urejene hierarhično ter jasno vidne iz menija. Študent se tako lahko pomika od strani do strani ali pa se skladno s potrebami premakne na poljubno vsebino.

Vse videoposnetke smo, s pomočjo v Moodlu integriranega orodja $\mathrm{H}_{5} \mathrm{P}$ za izdelavo interaktivnih vsebin, predelali $\mathrm{v}$ interaktivni videoposnetek. $V$ posnetke smo vstavili zaznamke (slika 6.3), ki študentu olaj-

${ }^{1}$ Študentje so pri vajah razporejeni v skupine z od 30 do 40 člani. Vaje opravljajo v računalniški učilnici s 15 stacionarnimi računalniki. Ker je izvedba vaj z več študenti na en računalnik neučinkovita, smo študente prosili, da na vaje pridejo s svojimi prenosniki. Žal obstoječe postaje za brezžični dostop do interneta niso sprejele tako velikega števila študentov naenkrat. 


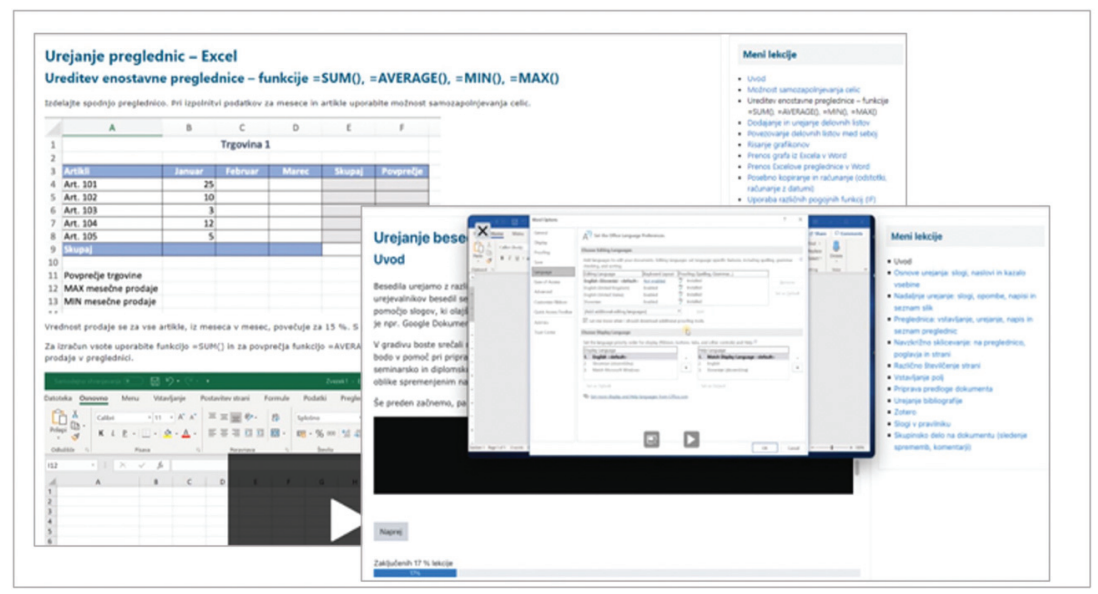

Slika 6.2 E-gradivo (Excel in Word)

Slika 6.3

Zaznamki v interaktivnem videoposnetku

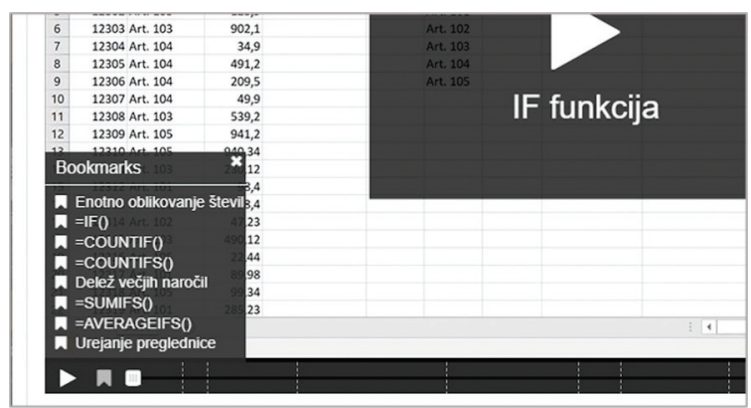

šajo navigacijo po posnetku. Tako se npr., če ne zna uporabiti funkcije =C O U N T I F S(), študent s klikom na ustrezni zaznamek pomakne neposredno na pojasnilo iskane vsebine (slika 6.3).

Moodlova lekcija je v pomoč tudi učitelju, saj mu nudi vpogled v statistiko uporabe e-gradiva (slika 6.4). Iz primera na sliki 6.4 je razvidno, da je Študent 1 na lekciji delal 5. in 9. oktobra 2020, lekcijo pa zaključil v petek, 16. oktobra 2020. K njej se je vrnil 26. oktobra 2020 in 26. aprila 2021. Iz statistike je razvidno, da se je vrnil na začetek lekcije (uporabnik se lahko vrne tudi na mesto, ki je bilo obiskano ob zadnji uporabi), zato deluje nezaključena. Nezaključeni so tudi primeri ostalih študentov, kar pomeni, da so se študentje po lekciji premikali skladno s potrebami, ne pa po straneh od začetka do konca. Ob zaključku statistike je razviden povprečen čas, ki so ga študentje porabili na lekciji (4 ure in 24 minut). $\mathrm{V}$ primeru na sliki 6.4 je sicer povprečni čas enak tudi najkrajšemu in 


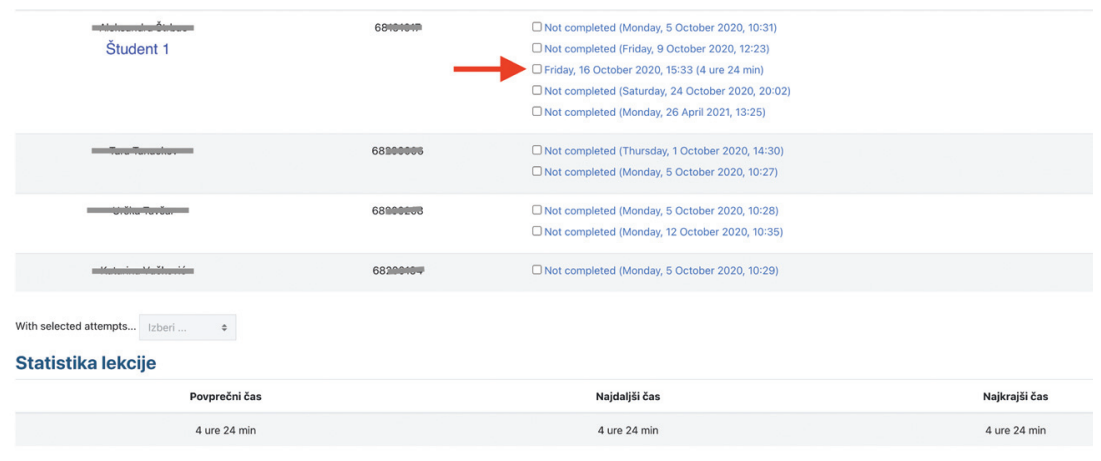

Slika 6.4 Statistika uporabe lekcije

najdaljšemu času, ki ga je posamezen študent prebil ob e-gradivu, saj je gradivo od začetka do konca pregledal le en študent (študent 1) in za pregled celotnega gradiva porabil 4 ure in $24 \mathrm{~min}$. E-gradivo ni vključevalo obveznega prehoda od strani do strani pa tudi ne vmesnih nalog, katerih pravilna rešitev bi pogojevala napredovanje po lekciji, zato so študentje večinoma pregledovali le vsebine, ki jih še niso poznali. Navigacija po lekciji je bila olajšana s prikazom menija lekcije.

Če so bila vsa e-gradiva združena pod enotno temo (poglavje) (slika 6.1), pa smo za vsak teden predvideli svojo temo. V uvodu so bili študentje seznanjeni z razporedom srečanj (slika 6.5). Le-ta so bila objavljena ob začetku izvedbe predmeta, medtem ko so se vsebine posameznih tednov študentom odpirale sproti. Kot omenjeno smo s študenti doma naučeno vsebino ponovili v šoli, podobno nalogo pa so izdelali še doma in jo, kot nalogo I K T-pismenosti, oddali do konca tedna.

Že teden pred zaprtjem univerze smo opazili, da se število študentov na vajah zmanjšuje. Tega seveda nismo povezovali s širjenjem virusa SAR S-COV-2, temveč s sezonskimi virusnimi obolenji. Dnevno časopisje (S T A 2020; Ferlič Žgajnar 2020) je poročalo o številnih izbruhih različnih virusnih obolenj, podobnih gripi. Upad števila prisotnih študentov smo opazili tudi pri predmetu I K T praktikum. Zato smo razmišljali o prenosu kontaktnih ur na splet in njihovem snemanju. Posnetki bi bili tako študentom dostopni od kjer koli in kadar koli, tudi tistim, ki so zaradi bolezni obležali doma. $V$ ta namen smo pripravili kratko anketo (»Prisotnost« na sliki 6.5). Od 36 študentov, kolikor jih je odgovorilo nanjo, jih je $24(66,7 \%)$ izrazilo željo po spletno izvedenih srečanjih; le dva študenta spletnih srečanj nista želela.

Preden pogledamo, kako smo izvedbo prilagodili epidemiji, predsta- 


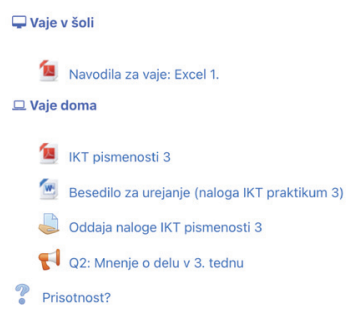

Prisotnost?

V preteklem tednu sem opazila, da vas je bilo na vajah veliko manj kot teden prej. Nekateri ste se opravičili, da ste obležali. Glede na vse dogodke okoli nas, me zanima, ali ste zdravi in boste prišli v šolo, ali pa bi mogoče razmišljali, da srečanje naredimo prek spleta (video-konferenca), to posnamem in si lahko potem še enkrat ogledate doma? Takšnega srečanja se seveda lahko udeležite od kjer koli.

Slika 6.5 IKT praktikum - teden pred prehodom na splet

vimo še način preverjanja znanja. Študentje torej študirajo po načelih obrnjenega učenja, znanje utrjujejo $\mathrm{v}$ šoli in doma, na koncu pa ga učitelj preveri še na izpitu. Izpit poteka $v$ računalniški učilnici, $s$ po 15 študenti naenkrat (za vsako mizo po en študent). Na izpitu od študentov pričakujemo, da s spletnega portala Statističnega urada Republike Slovenije (Si-Stat ${ }^{2}$ ) prenesejo izbrane podatke na svoj računalnik, jih uredijo $v$ Excelu ${ }^{3}$ ter graf in preglednico kasneje vstavijo v urejen Wordov dokument. Urejen Wordov in Excelov dokument študentje oddajo v eučilnico. Navodila za izpit prejmejo na papirju, neurejen Wordov dokument pa prenesejo iz e-učilnice. Izpit poteka 45 minut, je pa pred pričetkom z naslednjo skupino predvidenih 15 minut za podaljšanje, če je to potrebno. Končna ocena predmeta je sestavljena iz ocen opravljenih obveznosti pri obeh delih predmeta (Študijski praktikum - 30\%, I K T praktikum $-70 \%$ ), sama ocena I K T praktikuma pa iz ocene tedenskih nalog $(20 \%)$ in končnega izpita (80\%).

\section{Izvedba predmeta med epidemijo}

U P F M je pedagoški proces v obliko na daljavo prenesla 9. marca. Če je bila v klasični izvedbi zaradi prostorskih razmer (velikost računalniške učilnice) skupina za vaje ločena na dve podskupini, smo slednji pri

${ }^{2}$ Glej https://pxweb.stat.si/SiStat/sl.

${ }^{3}$ Študentje lahko uporabljajo tudi odprtokodno rešitev LibreOffice, čeprav glede na razpoložljive licence MS Office za študente raje uporabljamo Ms Office. 
IKT praktikum - 4. teden (9.3.-15. 3.)

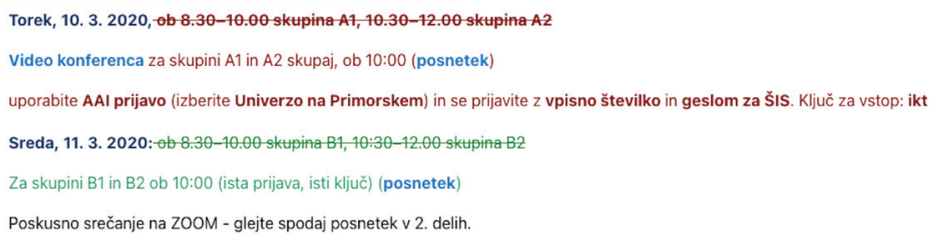

Slika 6.6 Prehod na splet

spletni izvedbi lahko združili (slika 6.6), saj videokonferenčna predavalnica omogoča večje število udeležencev sočasno. Prvo srečanje s študenti smo s pomočjo videokonferenčnega sistema Arnes vox izvedli že dan po zaprtju fakultete. V e-učilnici smo pustili vse predhodne najave srečanj, vendar smo termine klasične izvedbe sproti ${ }^{4}$ prečrtali in dodali povezave do spletnega naslova videokonference (slika 6.6). V prvem tednu je izvedba predmeta potekala prek Arnes vox-a, smo pa že sredi tedna, zaradi že omenjenih težav z Arnes vox-om, testirali brezplačno različico $\mathrm{ZOOM}-\mathrm{a},{ }^{5} \mathrm{ki}$ je omogočala do 40 minut dolga srečanja. Arnes VOX smo na UP FM uporabljali že leta in do epidemije sploh nismo razmišljali o alternativnem sistemu. Je preprost za uporabo, omogoča vnaprejšnje nalaganje vseh gradiv, ki jih kasneje uporabimo pri izvedbi, snemanje srečanj, deljenje zaslona, podeljevanje različnih vlog udeležencem itn. Edina pomanjkljivost je vezanost AdobeConnecta na aplikacijo Adobe Flash, za katerega je Adobe konec leta $2020^{6}$ ukinil podporo. Slabost Arnes V OX-a je bila tudi v tem, da je nameščanje aplikacije Flash posameznikom pogosto delalo težave in so s prijavo v videokonference zamujali ali pa so prijavni postopek morali ponavljati.

Študentje so se v Arnes $\operatorname{vox}^{7}$ prijavili prek A A I-prijave, ob prijavi pa jih je pričakala prosojnica $z$ napovednikom začetka srečanja. Namestitev takšne pozdravne prosojnice pred srečanjem je dobrodošla prednost Arnes vox-a. zoom deluje nekoliko drugače: da bi študentje lahko videli pozdravno prosojnico, se mora učitelj prijaviti in deliti zaslon svojega računalnika. $\mathrm{V}$ praksi to pomeni, da se je učitelj predmeta $\mathrm{V}$ zOOM-ovo videokonferenčno predavalnico prijavil 15 minut pred za-

\footnotetext{
${ }^{4}$ Prvotno je bilo predvideno, da bo zaprtje univerze trajalo le dva tedna.

${ }^{5}$ Glej https://zoom.us/pricing.

${ }^{6}$ Glej https://www.adobe.com/products/flashplayer/end-of-life.html.

${ }^{7}$ Glej https://vox.arnes.si/.
} 
Slika 6.7

Napovednika začetka srečanja v Arnes vox
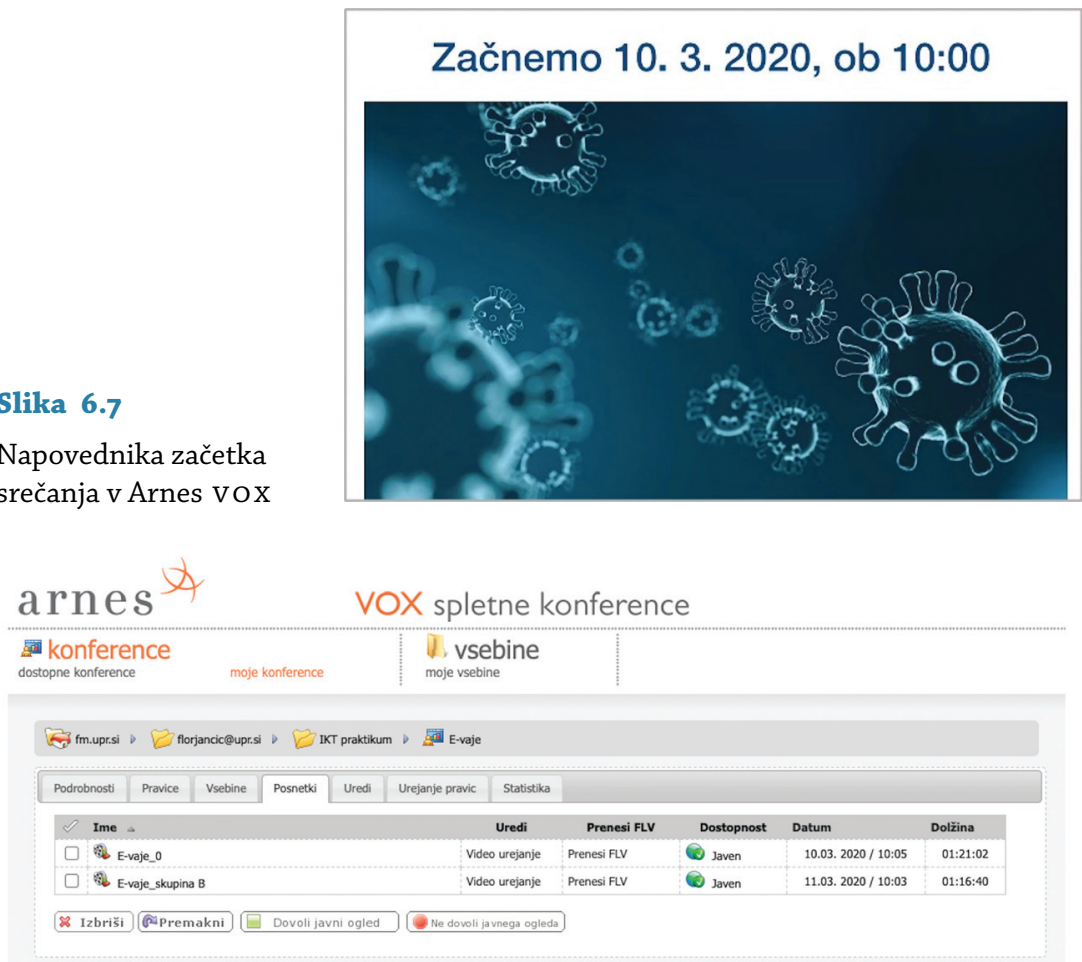

Slika 6.8 Posnetki srečanja na Arnes vox

četkom srečanja, delil zaslon računalnika in $\mathrm{z}$ uvodno prosojnico napovedal začetek srečanja.

Predstavitev snovi v okviru srečanj pri I K T praktikumu je izvajalka posnela, posnetke (slika 6.8) pa po povezavi v e-učilnici (slika 6.6) delila s študenti. Ti so si posnetke lahko znova ogledali, kar je bilo dobrodošlo pri opravljanju tedenskih domačih nalog. Med diskusijo se posamezna vprašanja študentov niso snemala.

$\mathrm{V}$ drugem tednu zaprtja univerze se je I K T praktikum začel izvajati prek videokonferenčnega sistema zo oM (slika 6.9).

Ker U P F M marca 2020 še ni imela licenc za uporabo zo o M-a, je izvajalka predmeta uporabljala prosto licenco, ki omogoča le do 40 minut dolga srečanja. Tako se je predavanje po 40 minutah samodejno prekinilo, izvajalka pa je bila s študenti dogovorjena, da po prekinitvi ponovno vstopijo prek iste spletne povezave in s srečanjem nadaljujejo. Srečanja so se snemala, izvajalka pa je na koncu posnetke združila v en videoposnetek na srečanje. Videoposnetke je naložila na Arnesov vide- 


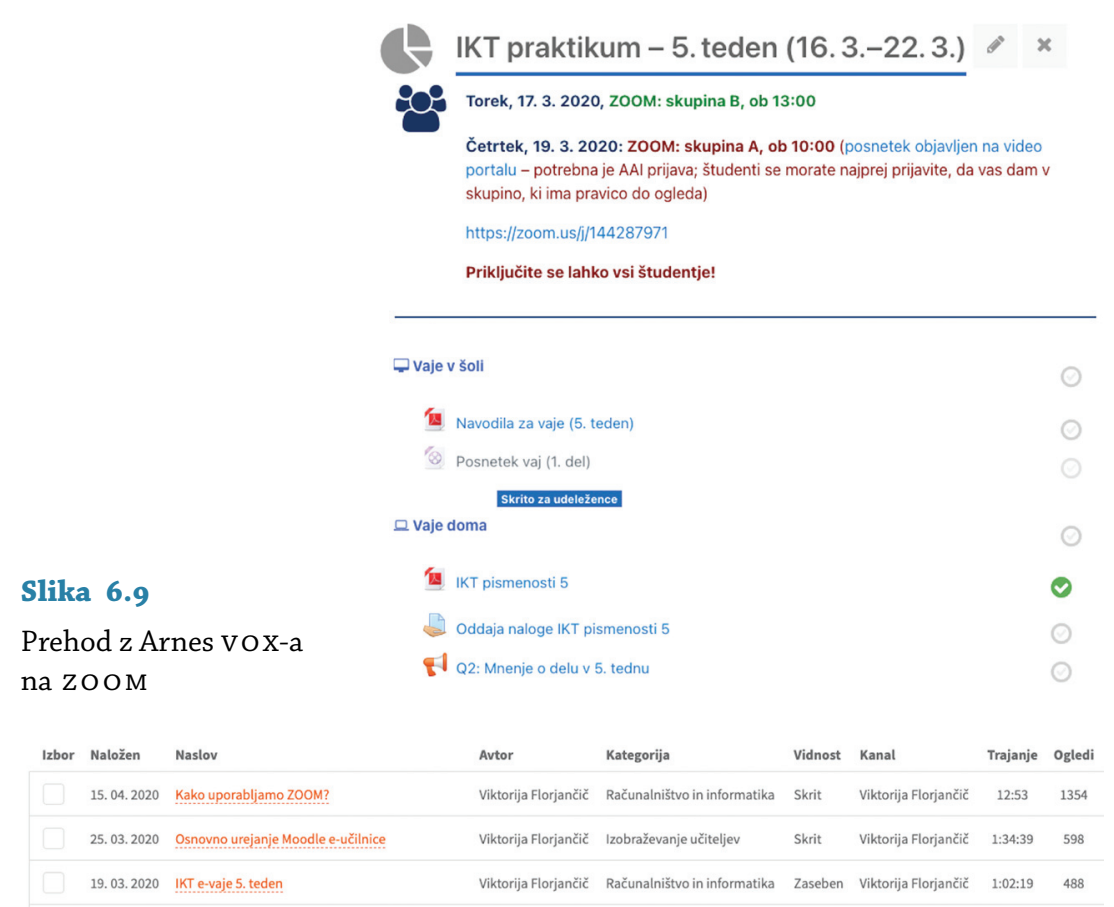

Slika 6.10 Posnetek na Arnesovem videoportalu

oportal (slika 6.10). ${ }^{8}$ Posnetki so bili, tako kot pri Arnes v ox-u, prek povezave deljeni v e-učilnici, kar pomeni, da so imeli dostop do njih le študentje. $S$ tem je izvajalka ohranila zasebnost ${ }^{9}$ na ravni tiste, ki jo imajo študentje v klasični učilnici.

zo OM je bil na začetku deležen kar nekaj kritik, tudi na račun varovanja zasebnosti in osebnih podatkov. Vse varnostne težave so sproti odpravljali in že sredi leta 2020 zagotovili varen prenos podatkov od uporabnika na strežnik, strežnike, ki so gostili videokonference registriranih uporabnikov iz E U, pa skladno z direktivo GDPR prenesli v EU. UP F M se je sredi aprila 2020 odločila za nakup licenc aplikacije zoOM za učitelje in si s tem zagotovila nemoteno izvedbo predavanj, daljših od 40 minut. Študentje so se v zo o M še vedno vključevali le prek povezav do videokonferenčnih predavalnic.

${ }^{8}$ Arnesov videoportal je v letu 2021 doživel prenovo, tako da zaslonska slika (slika 6.10) izkazuje novejši pogled.

${ }^{9}$ Študentje so med srečanji postavljali določena vprašanja, ki jih je učitelj sproti reševal in dodatno pojasnjeval. 
Če so se srečanja pri I K T praktikumu odvijala prek videokonferenc, pa so študentje domače naloge oddajali prek e-učilnice, kjer so prejeli tudi ocene in povratne informacije o rešenih nalogah.

\section{Preverjanje digitalnih spretnosti na daljavo}

Izvedba predmeta je, ne glede na epidemijo, tekla brez težav. Prvi izzivi so se pojavili pred kvartarnim izpitnim rokom. Izpit pri I K T praktikumu poteka v računalniški učilnici, ob prisotnosti učitelja. Postavilo se je vprašanje, kako verodostojno izvesti izpit na daljavo, na način, ki bo primerljiv s klasično izvedenim izpitom. Najprej smo načrtovali premik izpita na čas po epidemiji, ko bi se študentje ponovno vrnili v predavalnico, vendar so bili ti ideji večinsko nenaklonjeni. Svojo nenaklonjenost so podkrepili z dejstvom, da so bili dejavni celoten kvartal, sedaj bi pa na končno preverjanje morali čakati kvartal ali še dalj. Spraševali so se, ali bi potem ne bilo bolje, da med kvartalom sploh ne delali in bi prišli le na izpit. Njihovi argumenti so bili utemeljeni, zato smo s skupino študentov začeli iskati možnosti za izvedbo izpita na daljavo. Študentje so namignili, da bi se sami posneli, kar je seveda odprlo nova vprašanja, predvsem, kako zagotoviti verodostojnost opravljanja izpita. Po preverjanju različnih tehnologij smo izoblikovali izpitni protokol, ki ga predstavljamo v nadaljevanju. Razumevanje izpitnega protokola je pred posredovanjem celotni skupini študentov pri predmetu testirala skupina, ki je sodelovala pri iskanju rešitve za izvedbo izpita na daljavo. $\mathrm{Na}$ osnovi komentarjev in pripomb študentov smo nekatere vsebine dopolnili ali dodatno pojasnili. Izpitni protokol oziroma razumevanje protokola smo preverili še z ostalimi študenti. Za razumevanje izpitnega protokola smo pripravili videovodič (slika 6.12), v katerem smo simulirali opravljanje izpita, simulacijo pa podprli z dodatnimi pojasnili.

Izpitni protokol je bil razdeljen na dva dela, in sicer, kaj mora študent urediti pred izpitom in kako ravnati med izpitom.

Študent je pred izpitom:

- ustvaril račun na https://zoom.us/; račun si je ustvaril s poljubnim e-poštnim naslovom, v profil pa je moral vpisati svoje pravo ime in priimek; študentje so tako pridobili brezplačno osnovno licenco (angl. basic licence), ki uporabniku omogoča do 40 minut dolga zo OM-ova videokonferenčna srečanja in snemanje srečanja na lokalni računalnik;

- na svoj računalnik naložil program zo OM; 
Preverjanje in ocenjevanje znanja

Online izpit lahko opravljajo le študentje, ki so uvrščeni v eno od podskupin IKT_... (gl. svoj profil).

\section{Skupina}

IKT_AI) Skupina 2 Skupina A

Protokol za opravljanje izpita na daljavo

Kako opravljamo izpit? (video vodič)

Izpit - klepet

Slika 6.11 Preverjanje in ocenjevanja znanja na daljavo

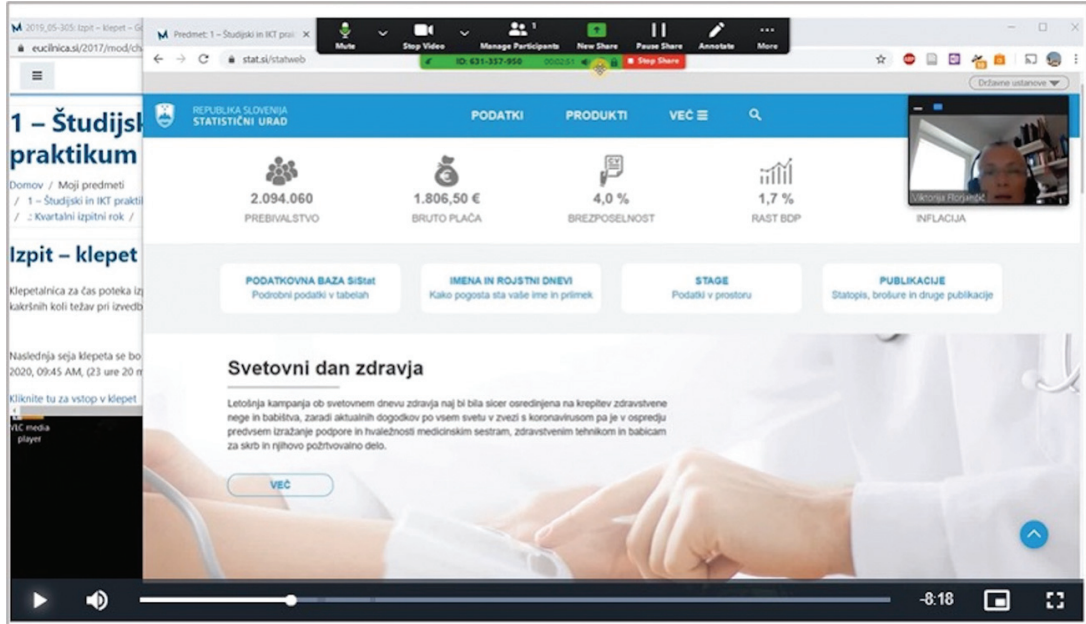

Slika 6.12 Videovodič opravljanja izpita

- $\mathrm{v}$ OneDrivu ${ }^{10}$ ustvaril mapo z imenom I K T_video, mapo pa dal v skupno rabo z učiteljem;

- zagotovil miren prostor brez motečih elementov;

- posodobil programsko opremo računalnika - operacijski sistem, programa Ms Office ter Zoom;

- zOOM nastavil brez navideznega ozadja;

${ }^{10}$ Študentje U P imajo dostop do Microsoftove (A3) licence za izobraževanje, ki jim omogoča uporabo oblačnih storitev 0365 ter namestitev paketa MS Office na njihove naprave. 
- preveril delovanje sistema - med izvedbo izpita je morala biti kamera računalnika vključena, prav tako zvok; študent ni smel uporabljati slušalk.

Spodaj navajamo, kaj je med opravljanjem izpita predvidel protokol.

- Študent se je prijavi v e-učilnico, kjer je imel med opravljanjem izpita podporo učitelja. Podpora se je vršila prek Moodlovega klepeta (izpit - klepet na sliki 6.11).

- Zaradi časovne omejenosti zooM-ovega srečanja je bil izpit razdeljen na dva dela. Študent je pet minut pred začetkom izpita na svojem računalniku zagnal osebno zo o M-ovo srečanje (angl. personal meeting).

- Študent je posnel postopek reševanja izpitne naloge. Na začetku se je predstavil - povedal svoje ime in priimek ter pred kamero pokazal svojo študentsko izkaznico (identifikacija študenta). Ob uri izpita je v e-učilnici prevzel prvi del izpitne naloge ${ }^{11}$ in začel reševati na način, da je snemal deljenje zaslona. Na zaslonu se je tako videlo, kaj študent dela, hkrati pa je bila vidna še njegova slika. Reševanje nalog je študent pospremil z govorom.

- Ob zaključku prvega dela naloge je študent zaključil snemanje, izstopil iz Z O OM-ovega srečanja in oddal rešen dokument. Drugi del naloge se je odprl 40 minut za prvim. Reševanje tega dela je potekalo na enak način kot reševanje prvega.

Pri izvedbi se je lahko pojavila le težava s pretvorbo videoposnetkov v M P 4, ki je onemogočila ponoven zagon novega Z O OM-ovega srečanja. Kasneje je bilo to odpravljeno oziroma je študent lahko prekinil preoblikovanje videoposnetkov in slednje izvedel po zaključku izpita. V izogib motnjam in težavam med izpitom je bil učitelj celoten čas izvedbe dosegljiv prek Klepeta v e-učilnici. Po potrebi se je čas za oddajo izpita podaljšal (npr. za študente s posebnim statusom, ki jim odločba omogoča daljši čas pisanja).

Izpit je tako vseboval dve datoteki, tako kot pri klasičnem izpitu, poleg tega pa še dva videoposnetka, deljena prek OneDriva, ki sta izkazovala, da je naloge res reševal študent sam. Izpitne naloge so bile ocenjene le, če so bile podprte $z$ videoposnetkoma, ki sta izkazovala verodostojnost izpita. Po vpisu izpitne ocene so študentje posnetke odstranili.

\footnotetext{
${ }^{11}$ Izpitne naloge so bile pripravljene s časovno omejitvijo in so se študentom, ki so imeli pravico pristopiti k izpitu, prikazale ob ustrezni uri.
} 
Študentje, ki izpita niso želeli opravljati na takšen način ali pa niso mogli zagotoviti s protokolom zahtevanih izpitnih pogojev, so $\mathrm{k}$ izpitu lahko pristopili kasneje. Žal pa je epidemiološka situacija onemogočila klasično izvedbo izpitov in so vsi študentje obveznosti I K T praktikuma opravljali na daljavo. V izogib težavam smo $\mathrm{z}$ vsemi študenti opravili testiranje protokola in kasneje po potrebi omogočili tudi individualno svetovanje - je bilo pa takšnih svetovanj malo. Študentje so preverjanja znanja na daljavo s pomočjo videovodiča in vseh navodil opravljali brez težav.

\section{Odziv študentov na izvedbo IK T praktikuma}

Ob zaključku izvedbe predmetov vedno opravimo anketo o izvedbi. Mnenje študentov se sicer preverja že med izvedbo, saj želimo morebitne težave zaznati že takrat in jih tudi pravočasno rešiti. Takšno sprotno reševanje težav in nesporazumov je pri klasični izvedbi, brez podpore v e-učilnici in ob velikem številu študentov, težje. Študentje se namreč neradi izpostavljajo in javno izražajo svoja mnenja.

$\mathrm{Na}$ anketo o izvedbi predmeta je odgovorilo 21 študentov UN programa (65,6-odstotni odziv) in 36 študentov Vs programa (53,7-odstotni odziv). Podatke o skupini UN študentov navajamo za primerjavo, saj je bil predmet za to skupino $\mathrm{v}$ celoti izveden klasično, vendar s podporo eučilnice, pri skupini vs študentov pa je bila polovica predmeta izvedena po spletu. Prek spleta sta potekala tudi končna preverjanje in ocenjevanje znanja.

Študentje so na štiristopenjski Likertovi lestvici ${ }^{12}$ presojali navodila in gradiva. Štiristopenjsko lestvico smo uporabili zato, ker smo želeli, da študentje jasno izrazijo strinjanje (oceni 3 ali 4) ali nestrinjanje (oceni 1 ali 2). Kot je razvidno iz povprečnih ocen (preglednica 6.1), so študentje e-gradivom naklonjeni: gradiva so bila uporabna in študentje niso imeli težav z uporabo in učenjem z njihovo pomočjo. Med skupino študentov UN programa, za katere se je predmet izvedel klasično, in skupino vs, ki so imeli delno spletno izvedbo, statistično značilnih razlik ni bilo. Študentje bi si e-gradiv želeli tudi pri drugih predmetih (UN: $M=3,7$; Vs: $\mathrm{M}=3,5)$.

Zanimivi so odgovori študentov o obsežnosti in zahtevnosti študijskih obveznosti. Kot omenjeno se je izvedba za UN in VS skupino študentov razlikovala $v$ delu izvedbe (za vs skupino je bila izvedba od 4 .

\footnotetext{
${ }^{12} 1$ = sploh se ne strinjam, 2 = ne strinjam se, 3 = delno se strinjam, 4 = povsem se strinjam.
} 
Preglednica 6.1 Mnenja študentov I K T praktikuma o gradivih (2019/2020)

\begin{tabular}{lcc}
\hline Trditev & U N & VS \\
\hline Navodila za študij so razumljiva. & 3,7 & 3,4 \\
E-gradiva so razumljiva. & 3,6 & 3,6 \\
E-gradiva so nazorna. & 3,5 & 3,5 \\
E-gradiva so podrobna. & 3,7 & 3,3 \\
E-gradiva so neuporabna. & 1,5 & 1,6 \\
Ne morem se učiti s pomočjo e-gradiv. & 1,8 & 1,7 \\
\hline
\end{tabular}

Preglednica 6.2 Študijske obveznosti pri I T praktikumu (2019/2020)

\begin{tabular}{lcc}
\hline Trditev & U N & VS \\
\hline Izvedba predmeta je bila boljša, kot ste pričakovali & 3,5 & 3,5 \\
Študijske obveznosti so bile obsežne. & 3,2 & 2,7 \\
Študijske obveznosti so bile zahtevne. & 2,8 & 2,6 \\
Preverjanje znanja je bilo skladno z učnim načrtom. & 3,7 & 3,5 \\
Predmet je možno opraviti le s sprotnim delom. & 3,1 & 3,2 \\
Obveznosti ste opravili brez težav. & 3,0 & 3,1 \\
\hline
\end{tabular}

tedna po spletu) ter $\mathrm{v}$ načinu izvedbe izpita. vs skupina je izvajanje izpita posnela, saj je izpit opravljala na daljavo. Za študente študijske obveznosti niso bile zahtevne, saj so povprečne ocene zahtevnosti pod 3 . Zanimivo je, da za skupino vs študijske obveznosti tudi niso bile obsežne $(M=2,7)$, medtem ko je bilo za študente UN skupine obveznosti veliko, pa čeprav so opravljali iste naloge. Večjih razlik med obema skupinama ni bilo. Obe skupini študentov sta izboljšali svoje sposobnosti uporabe računalnika in interneta na splošno ( $\mathrm{UN}: \mathrm{M}=3,6, \mathrm{VS}: \mathrm{M}=3,5)$, kar je tudi cilj predmeta (preglednica 6.2).

Študentje Vs programa so bili po zaključku izvedbe predmeta nekoliko bolj naklonjeni študiju online $(\mathrm{M}=3,2)$ od študentov U N programa $(M=3,1)$. So pa študentje po 1. kvartalu izrazili nekoliko večje zadovoljstvo s študijem na U P F M kot študentje V S programa na koncu 3. kvartala. Na petstopenjski lestvici ( 5 je najvišja ocena) so U N študentje svoje zadovoljstvo ocenili s povprečno oceno 4,3 , študentje vs programa pa S 3,9. U N študentje naj bi v študij na U P F M vložili v povprečju 21,5 ure na teden (za I K T praktikum 7,3 ure), vs študentje pa 14,2 ure (za I K T praktikum 6,6 ure). Razlika v času, ki so ga študentje namenili za delo pri predmetu, je razvidna tudi iz statistike e-učilnice. Vtičnik Dedication tool izkazuje, da so U N študentje e-učilnico v povprečju uporabljali 1.197,67 minute, študentje vs programa pa 1.102,97 minute. Manj pora- 


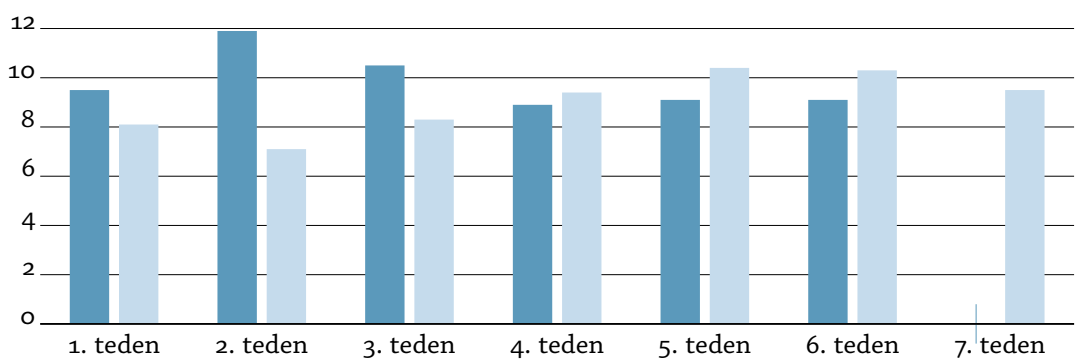

Slika 6.13 Obremenitev študentov po tednih (2019/2020; temno UN, svetlo Vs)

bljenega časa pri vs študentih najbrž izhaja iz tega, da je bila polovica predmeta izvedena po spletu, srečanja so se snemala, posnetke pa so si študentje lahko ogledali kasneje. Ogled posnetkov ni zabeležen v predstavljenem času.

Mnenja študentov o delu pri predmetu zbiramo tudi $\mathrm{v}$ tedenskih mnenjskih anketah. Na osnovi podatkov smo izračunali povprečno število ur na teden. Običajno študentje na začetku vložijo več časa v opravljanje študijskih obveznosti, saj se morajo najprej spoznati z načinom in organizacijo dela na fakulteti. Kot je razvidno iz slike 6.13, so študentje UN programa v prvem delu izvedbe predmeta porabili enkrat več časa od študentov Vs programa. Razlika je nedvomno povezana $z$ obdobjem izvedbe - za študente UN programa se je predmet izvedel na začetku študija, ko so prišli v novo učno okolje in so se šele spoznavali z njim. Za študente vs programa je bila e-učilnica že poznana in so za spoznavanje organizacije predmeta porabili manj časa. Zanimivo pa je, da so študentje s prehodom na splet (4. teden) za študij potrebovali več časa kot v prvih treh tednih, ko je bila izvedba klasična. To vsekakor ovrže sume, da je študij na daljavo manj zahteven. Študentje so v študij vlagali celo več časa kot prej. Običajno sicer predmete zastavim tako, da obremenitev študentov s časom izvedbe pada. Pri študentih UN skupine za 7. teden nismo zbirali podatkov o delu, tako da tega podatka ni.

$\mathrm{Na}$ osnovi izračunane ponderirane ${ }^{13}$ tedenske povprečne obremenitve študentov, pri čemer smo upoštevali čas, o katerem so študentje poročali v tedenskih mnenjskih anketah (slika 6.13), in čas, o katerem so poročali v anketi o izvedbi predmeta, lahko rečemo, da je povprečni študent 1. letnika v obveznosti I K T praktikuma vložil 8,o8 ure na teden.

\footnotetext{
${ }^{13}$ Pri izračunu upoštevam število študentov, ki so se odzvali na anketo o izvedbi predmeta.
} 
Upoštevajoč sedem tednov je bil tako povprečen študent pri predmetu obremenjen s 56,6 ure. Upoštevajoč $2 \mathrm{KT}$, kolikor so ovrednotene obveznosti I K T praktikuma, in merila E C T S, ${ }^{14}$ po katerih mora študent za $1 \mathrm{~K} \mathrm{~T}$ v opravljanje študijskih obveznosti vložiti od 25 do 30 ur svojega dela, lahko trdimo, da so bili študentje pri predmetu ustrezno obremenjeni. Iz ankete sicer izhaja (slika 6.2), da študentje UN programa menijo, da so bile obveznosti obsežne. Razliko lahko pojasnimo s tem, da ti študentje na fakulteto prihajajo s slabše razvitimi spretnostmi uporabe računalnika in interneta od študentov vs programa. Sicer pa je na podlagi poročil študentov $\mathrm{v}$ mnenjski anketi povprečje ur na teden na U N programu $(M=10,0)$ nekoliko višje od povprečja na VS programu $(\mathrm{M}=8,9)$.

Glede na prikazane podatke lahko ugotovimo, da delni prenos izvedbe predmeta IK T praktikum na splet ni v ničemer okrnil same izvedbe predmeta.

\subsection{IKT praktikum 2020/2021}

Predmet I K T praktikum smo prvič izvedli v študijskem letu 2019/2020. Analiza podatkov preteklega študijskega leta je pokazala, da izvedba zaradi epidemije in prenosa izvedbe predmeta na splet ni bila oškodovana. Čeprav se je študijsko leto 2020/2021 začelo klasično, smo predmet na U N programu že od 1. oktobra izvajali na daljavo. K tej odločitvi so prispevali pozitivne izkušnje iz prvega vala epidemije ter predvidevanje, da se obeta drugi val. V študijskem letu je avtorica monografije predmet, katerega nosilka je, v celoti izvajala le za skupino UN študentov, zato zaradi primerljivosti $v$ nadaljevanju prikazujemo izvedbo in evalvacijo predmeta le za skupino UN študentov.

UP je za študijsko leto 2020/2021 uvedla dve novosti. Prva je vezana na nabavo zoo M-ovih licenc za vse učitelje in študente. Odločitev se je, kot bomo prikazali kasneje, izkazala za smiselno in uporabno, saj so se vsa srečanja lahko izvajala neomejeno dolgo, licenca pa je omogočala tudi shranjevanje posnetkov na zoo M-ov oblak. Licenčna različica Z O O M-a je vzpostavila možnost spremljanja liste prisotnih študentov, kar je, v povezavi s šolskimi računi študentov, olajšalo delo učitelja. Druga pozitivna sprememba, ki smo jo uvedli, tudi po zaslugi projekta InoTeZ, je poenotena obvezna uporaba šolskih e-poštnih naslovov študentov. Študentje ob vpisu na U P dobijo šolske e-poštne naslove, ki so

\footnotetext{
${ }^{14}$ Glej http://pisrs.si/Pis.web/pregledPredpisa?id=MERI23.
} 

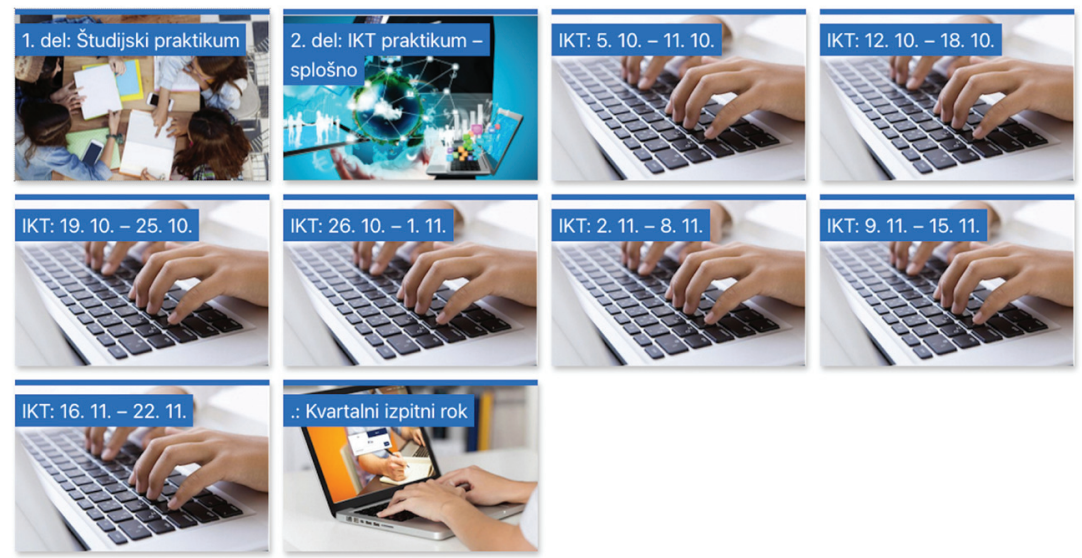

Slika 6.14 Postavitev predmeta v e-učilnici

vneseni tudi v e-učilnico in š I s, ${ }^{15}$ od študentov pa smo zahtevali, da vsa komunikacija s fakulteto poteka le prek teh naslovov.

Na UP FM smo pripravili videovodiča, kako ravnati s šolskim epoštnim naslovom ter kako prevzeti študentski z o o M-ov račun. Videovodiča sta bila namenjena predvsem študentom višjih letnikov, saj smo ravnanje s šolskim e-poštnim naslovom ter prevzem zo o M-ovega računa vključili v prve ure I K T praktikuma in tako študente že na začetku pripravili tudi za delo na daljavo. Za ostale študente smo videoposnetka vključili v Podporo študentom (slika 6.15).

\section{Izvedba predmeta na daljavo}

Pri pripravi načrta izvedbe predmeta smo izhajali iz učnega načrta in izkušenj predhodnega leta, predvsem izvedbe v prvem valu epidemije covida-19. Glede na to, da smo se odločili za e-izvedbo, smo takšen način izvedbe vključili že v načrt izvedbe predmeta. Odločitev se je kmalu izkazala za pravilno, saj je univerza zaradi drugega vala epidemije že sredi oktobra 2020 pedagoški proces $v$ celoti prenesla v obliko dela na daljavo. U P F M je nekatere svoje aktivnosti na začetku študijskega leta (pozdrav brucem) izvajala na daljavo, prek zooM-a, in na ta način tudi novincem olajšala popolni prehod $\mathrm{v}$ obliko dela na daljavo.

Avtorica monografije je osebno sicer naklonjena asinhronemu na-

${ }^{15}$ Študentski informacijski sistem, v katerem se vodijo vse s študentom povezane evidence (vpis, prijava in odjava na izpit, e-indeks, oddaja in obravnava vlog ipd.). 


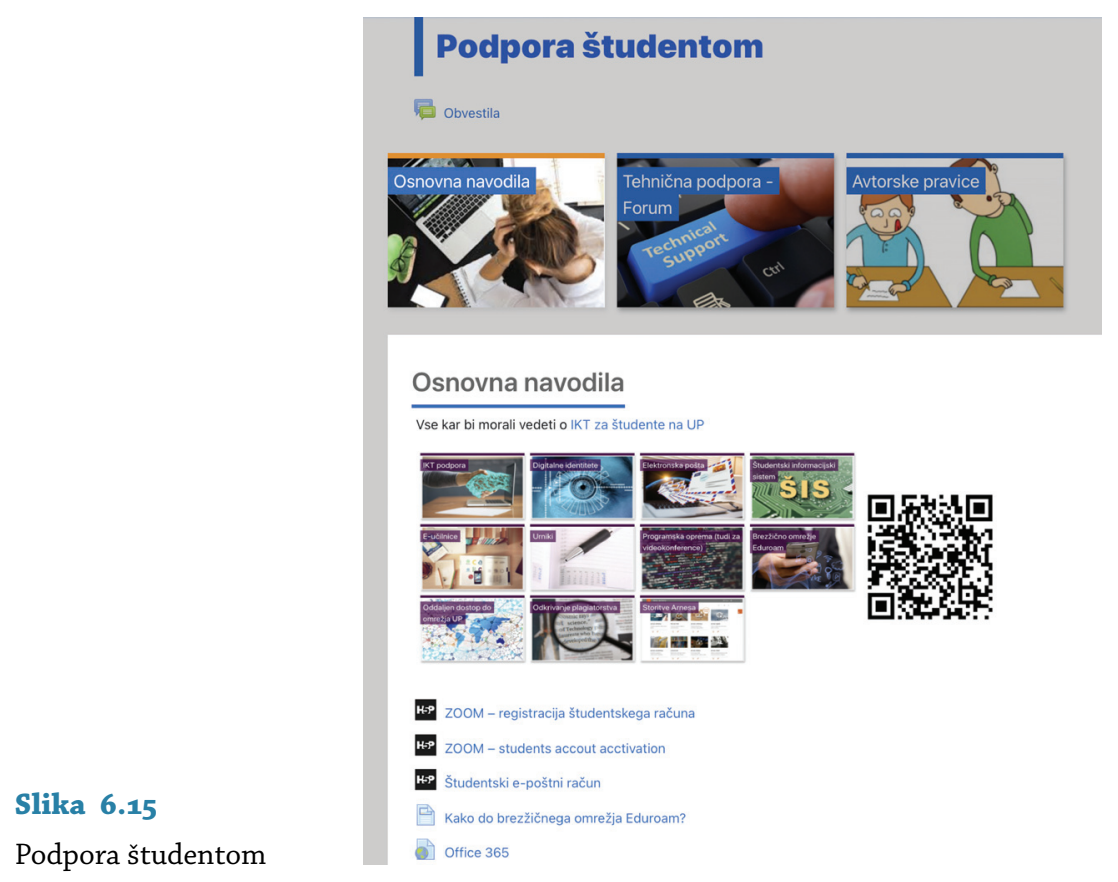

činu dela na daljavo, saj takšen način omogoča fleksibilnost dela, ki je osrednja prednost študija na daljavo v primerjavi s klasično izvedenim študijem (Bates 2005, 188-189). Vendar je bilo na U P načrtovano, da se klasično izvedene ure nadomesti s sinhronim načinom izvedbe in o tem tudi poroča $\mathrm{v}$ univerzitetni informacijski sistem (U N IS). Tako smo predmet izvajali prek videokonferenčnega sistema zo OM in na ta način kombinirali predavanja in vaje. V zo o M-u smo za vsak predmet odprli t.i. spletno predavalnico s ponavljajočimi se (angl. recurring) srečanji, brez vnaprej določenega datuma in ure (slika 6.16).

Povezavo do predmetne videokonferenčne sobe smo s študenti delili prek e-učilnice. Takšen pristop je olajšal delo, saj so imeli študentje vedno isto povezavo (le-ta se shrani tudi v ZO O M-ovi namizni aplikaciji) (slika 6.17), učitelj pa ima v zooM-ovi nadzorni plošči boljši pregled nad izvedbami (evidenca prisotnosti - slika 6.18 in evidenca posnetkov - slika 6.19).

Iz pregleda izvedenih srečanj (Reports | Usage Reports v zo o M-u slika 6.18) so razvidni predmet (Topic), datum izvedbe in trajanje ter število udeležencev na srečanju. Polja v poročilu lahko poljubno nastavljamo (slika 6.18 - Toggle columns). 


\begin{tabular}{|c|c|}
\hline \multicolumn{2}{|l|}{ Recurring } \\
\hline \multirow[t]{2}{*}{ Recurring } & InoTeZ \\
\hline & Meeting ID: 173284246 \\
\hline \multirow[t]{2}{*}{ Recurring } & UP FM podpora \\
\hline & Meeting ID: 83645749483 \\
\hline \multirow[t]{2}{*}{ Recurring } & Mentoriranje/Govorilne ure \\
\hline & Meeting ID: 83966358188 \\
\hline \multirow[t]{2}{*}{ Recurring } & IKT praktikum - UN redni \\
\hline & Meeting ID: 87281304233 \\
\hline \multirow[t]{2}{*}{ Recurring } & Poslovna informatika (UN) \\
\hline & Meeting ID: 86313801201 \\
\hline \multirow[t]{2}{*}{ Recurring } & Poslovna informatika VS (izredni) \\
\hline & Meeting ID: 82090399965 \\
\hline \multirow[t]{2}{*}{ Recurring } & Poslovna informatika VS (redni) \\
\hline & Meeting ID: 88922896870 \\
\hline
\end{tabular}

Slika 6.16

zoom-ove spletne predavalnice

Vsebinsko predstavitev snovi smo posneli na zoo M-ov oblak. Delo $\mathrm{v}$ ločenih skupinah in diskusije se niso posneli. Posnetki na oblaku se, glede na administrativne nastavitve univerzitetnega zooM-ovega računa, hranijo do go dni (slika 6.19). Seveda lahko učitelj posnetke zbriše ali pa si jih prinese na svoj računalnik. Pred dejanskim izbrisom uporabnik prejme obvestilo na e-poštni račun (slika 6.20).

Če bi učitelj želel ohraniti videoposnetek, bi ga lahko prenesel na svoj računalnik in ga nato naložil na splet, na primer na Arnesov videoportal. $^{16}$

Možnost snemanja na oblak je bila dobrodošla sprememba v študijskem letu 2020/2021, saj je uporabniku prihranila prostor na lokalnem disku, odpravljeno pa je bilo tudi čakanje za preoblikovanje videoposnetka na disku. Učitelj je tako lahko ob zaključku enega predavanja začel z drugim, preoblikovanje videoposnetkov v MP4 pa je potekalo v ozadju.

${ }^{16}$ Glej https://video.arnes.si/. 
IKT: 12. 10. - 18. 10.

\begin{tabular}{|c|c|c|}
\hline & & Srečanja: \\
\hline & Meeting ID: 872 onvor & 12. 10.2020 , ob $9: 30$ \\
\hline & Obvezna prijava s študentsko prijavo & 15. 10.2020, ob $9: 30$ \\
\hline & & 16. 10.2020, ob $13: 00$ \\
\hline
\end{tabular}

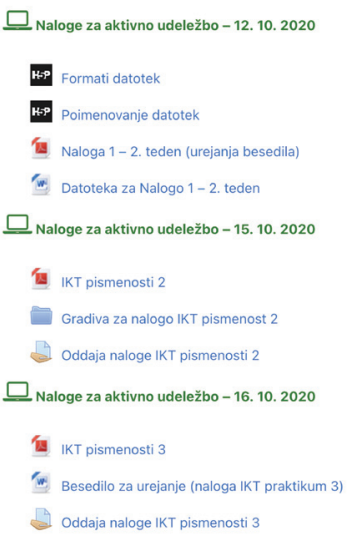

Slika 6.17 Primer ureditve teme v e-učilnici

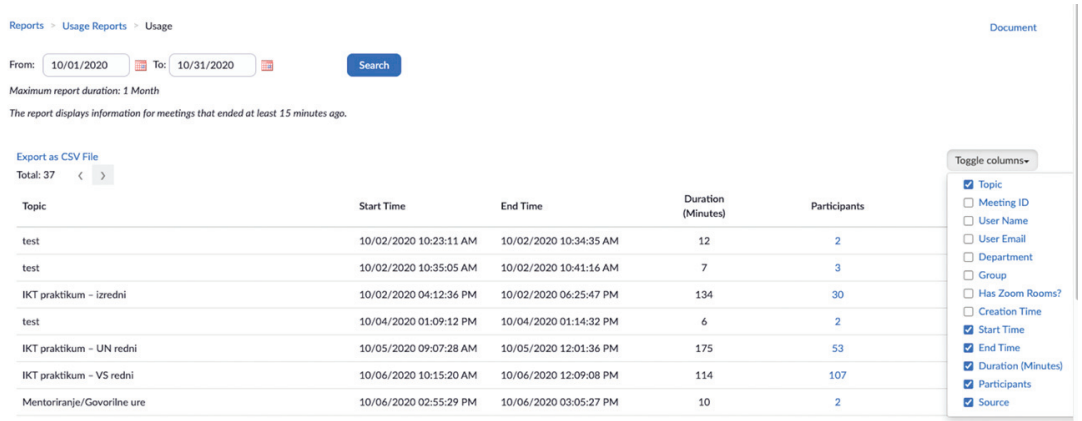

Slika 6.18 Pregled izvedenih zooM-ovih srečanj

Od študentov smo zahtevali, da se v zoom prijavijo prek šolskega računa, kar je olajšalo obdelavo podatkov o prisotnosti. Podatke iz ZOOM-a smo namreč prenesli v MS Excel, iz e-poštnega naslova izluščili vpisno številko, ${ }^{17}$ vsebino delovnega lista skopirali v datoteko

${ }^{17}$ E-poštni naslovi študentov UP so sestavljeni iz vpisne številke in domene @student.upr.si. Glede na to, da je vpisna številka dolga osem mest, smo uporabili funkcijo =L E F T(B 2;8), ki je povrnila prvih osem znakov z leve strani. 
6 Evalvacija izvedb predmetov s področja poslovne informatike

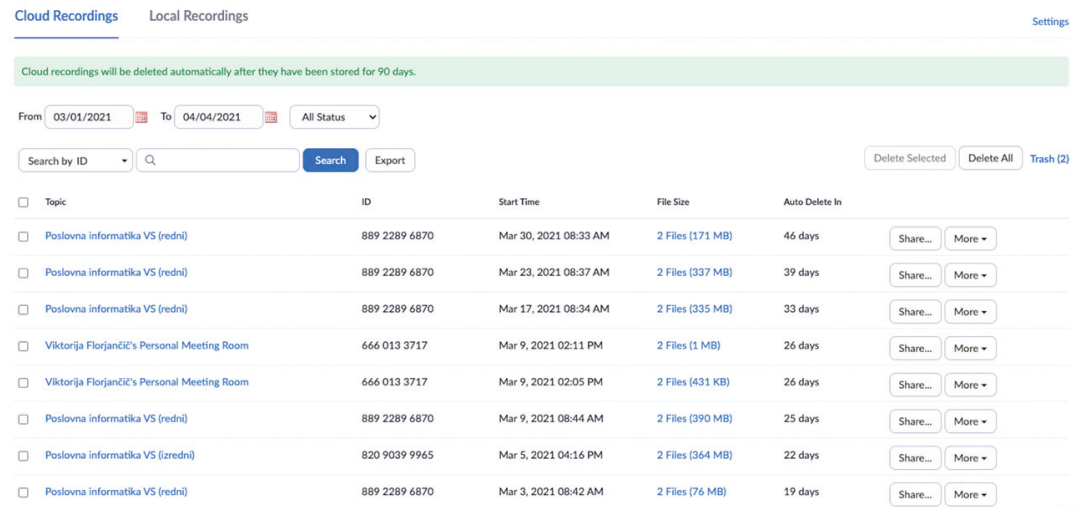

Slika 6.19 Pregled posnetkov zoom-ovih srečanj

Z Zoom <no-reply@zoom.us>

Čet 13. Maj 2021 11:27

Za: Viktorija Florjančič

\title{
zoom
}

\author{
Hi Viktorija Florjančič, \\ You have recording(s) that will be permanently deleted in 7 days, please click the link below if \\ you want to restore the recording(s). \\ Meeting recordings \\ https://upr-si.zoom. us/recording/trash?dateFrom=04/14/2021\&dateTo=04/21/2021
}

○ (1) (1)

Copyright 02019 Zoom Video Communications, Inc. All rights reserved.

55 Almaden Boulevard, 6th Floor, San Jose, CA 95113

$+1.888 .799 .9666$

Slika 6.20 Obvestilo o izteku 9o-dnevnega roka

prisotnosti ter $\mathrm{s}$ funkcijo $=$ COUNTIF () povezali seznam študentov $\mathrm{s}$ prisotnostjo na posameznem srečanju (delovni listi v Excelovi tabeli) (slika 6.21).

Pri manjšem številu študentov je vodenje prisotnosti sicer enostavno, pri večjem pa opisan pristop z nekaj kliki v MS Excelu prihrani čas. Na sliki 6.21 prikazujemo podatke predmeta, ki se je izvajal v 2. kvartalu, vendar je načelo enako izvedbi pri I K T praktikumu v 1. kvartalu. Udeležba na predavanju je bila na koncu izvedbe predmeta nagrajena $s$ 


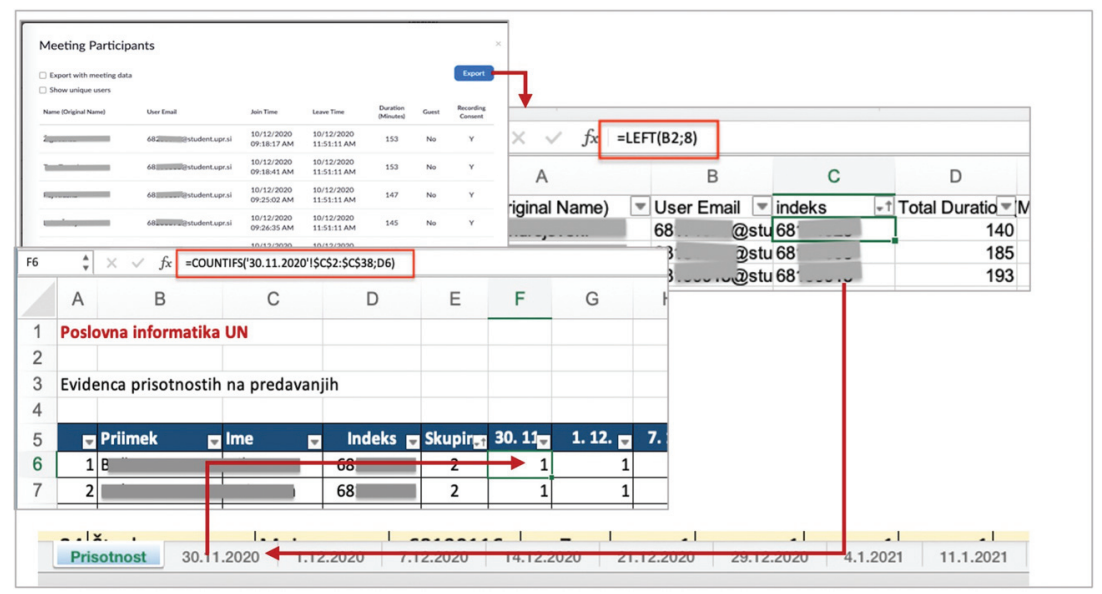

Slika 6.21 Prenos in povezava podatkov prisotnih študentov

točkami. Brez prijave študentov s šolskim zo o M-ovim računom bi za vodenje prisotnosti potrebovali več časa.

Študentje so med z o o M-ovimi srečanji opravljali določene naloge, ki so jih do konca dneva morali oddati v e-učilnico. Študentje, ki se videokonferenčnega srečanja niso mogli udeležiti, so si lahko tekom dneva ogledali posnetek srečanja in naloge oddali do polnoči. S takšnim pristopom smo kljub sinhroni izvedbi uvedli nekoliko fleksibilnosti. Vedeti moramo, da so od doma delali tudi starši in mlajši sorojenci in je bilo, glede na domače prostorske zmožnosti, nekaterim težko zagotoviti prisotnost ob točno določenem času.

\section{Preverjanje digitalnih spretnosti na daljavo}

Preverjanje znanja je potekalo na nekoliko spremenjen način, kot smo ga razvili v prvem valu epidemije. Sprememba je vezana na pridobitev zo O M-ovih licenc za študente. Ti so lahko sedaj zo o M uporabljali neomejeno dolgo. Srečanja so lahko snemali, posnetke pa, po izbiri, shranjevali na oblak ali svoj računalnik. Tako ni bilo več potrebe po razdeljevanju izpita na dva dela in smo izpit izvedli tako kot pri klasični izvedbi, $\mathrm{v}$ enem delu. Študentje so, tako kot v prvem valu, prišli v e-učilnico, se vključili v Klepet ter počakali na začetek izpita. Izpitno nalogo so, tako kot v prvem valu, prevzeli v e-učilnici, zo oM-ovo srečanje pa izvedli s svojim šolskim zo o M-ovim računom. Študentje so snemali na z O M M-ov oblak in nato povezavo delili prek Naloge v e-učilnici (slika 6.22). Učitelj je nalogo ocenil in študentu v komentarju, poleg komen- 


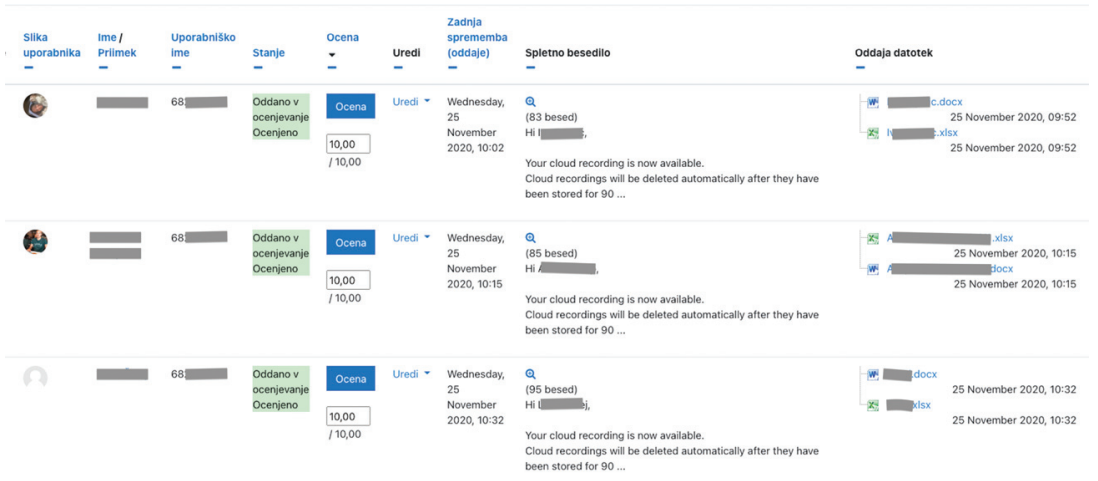

Slika 6.22 Oddaja izpitne naloge in povezave do zo o M-ovega video posnetka

... le zato, ker je bilo to potrebno.

... ker so bila srečanja koristna.

... ker bi se brez srečanj težko vsega naučili.

1,9

... so bila nekoristna

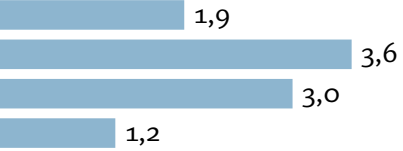

Slika 6.23 ZOOM-ova srečanja (mnenja študentov)

tarja o reševanju nalogu, zapisal, da lahko videoposnetek zbriše. Če študent videoposnetka ni zbrisal (ta je bil viden le študentu in prek povezave ter gesla vsem, $s$ katerimi je študent delil podatke - v našem primeru učitelju), se je samodejno zbrisal skladno z nastavitvijo univerzitetnega zo o M-ovega računa (v 90 dneh).

\section{Odziv študentov}

Pri predmetu Študijski in I K T praktikum je bilo vpisanih 38 študentov, vendar jih je predmet opravljalo le 31. Vedeti je potrebno, da se nekateri študentje $\mathrm{v}$ visokošolski študij vpisujejo tudi le zaradi statusa in nimajo namena opravljati študijskih obveznosti. Populacijo študentov 1. letnika tako sestavlja 31 študentov. Anketo o izvedbi predmeta je izpolnilo 27 študentov (87,1-odstotni odziv). Študentje so, tako kot je navada pri predmetih avtorice monografije, svoje odzive oddajali tudi po vsakem zaključenem tednu.

Vprašanja so bila podobna kot v preteklem študijskem letu, dodali smo le vprašanja, ki so bila povezana $z$ izvedbo srečanj prek videokonference. Študentje so strinjanje/nestrinjanje s trditvami glede z O OM-ovega srečanja izražali na štiristopenjski lestvic ( 1 in $2=$ nestrinjanje, 3 in 4 = strinjanje) (slika 6.23). 
Preglednica 6.3 Primerjava mnenj o gradivih

\begin{tabular}{lrrrrr}
\hline Trditev & \multicolumn{2}{c}{$2019 / 2020$} & & $2020 / 2021$ \\
\cline { 2 - 3 } & U N & VS & & UN \\
\hline E-gradiva so razumljiva. & 3,6 & 3,6 & & 3,6 \\
E-gradiva so nazorna. & 3,5 & 3,5 & & 3,5 \\
E-gradiva so podrobna. & 3,7 & 3,3 & & 3,6 \\
E-gradiva so neuporabna. & 1,5 & 1,6 & & 1,4 \\
Ne morem se učiti s pomočjo e-gradiv. & 1,8 & 1,7 & & 1,8 \\
\hline
\end{tabular}

Z O O M-ova srečanja so bila za študente koristna $(M=3,6)$ in so jim pomagala pri študiju. Brez njih bi se težko naučili vse, kar je bilo potrebno $(M=3,0)$. Posnetki srečanj so bili med študenti zelo dobro sprejeti, saj so njihovo uporabnost na štiristopenjski lestvici v povprečju ocenili z oceno 3,4, kar kaže na visoko strinjanje.

Študentje so uporabljali enaka e-gradiva kot tisti leto prej, tako da ne preseneča, da so bili odzivi primerljivi (preglednica 6.3). Študentje so strinjanja/nestrinjanja $s$ trditvami podajali na štiristopenjski lestvici. Oceni 1 in 2 predstavljata nestrinjanje, oceni 3 in 4 pa strinjanje. Kot je razvidno iz preglednice 6.3, so študentje e-gradiva dobro sprejeli. Zato ne preseneča zelo visoko strinjanje $(M=3,6)$ s trditvijo, da bi si podobnih gradiv želeli tudi pri drugih predmetih, kar je podobno ocenam predhodnega leta (U 19/20: $M=3,7$; VS19/20: $M=3,5$ ).

I K T praktikum se je v celoti izvajal po spletu, zato je zanimiva primerjava $\mathrm{z}$ izvedbo $\mathrm{v}$ preteklem letu, kjer se je predmet za skupino UN študentov izvajal klasično, za skupino vs študentov pa se je po spletu predmet izvajal od 4. tedna naprej. Kot je razvidno iz preglednice 6.4, so UN študentje 2020/2021, kljub celotni izvedbi po spletu, lažje opravili študijske obveznost $(M=3,6)$ in kljub temu, da smo dodali nekaj novih nalog, so bile študijske obveznosti zanje manj zahtevne $(M=2,2)$ kot za študente študijskega leta 2019/2020. K lažjemu opravljanju nalog so nedvomno prispevali posnetki razlage snovi, ki so si jih študentje lahko ogledovali vedno znova. Možnost ponovnega ogleda posnetkov so pohvalili tudi v prostih komentarjih.

$\mathrm{Z}$ načinom izvedbe predmeta so bili študentje zadovoljni. Če izpostavimo le en komentar na vprašanje, če bi še kaj povedali:

Izvedbe predmetov $\mathrm{v}$ tem času so glede na razmere odlično izpeljane in prilagojene. Pretekle izkušnje $\mathrm{z}$ delom na daljavo so bile veliko bolj neučinkovite in neorganizirane. 
Preglednica 6.4 Primerjava mnenj o študijskih obveznostih

\begin{tabular}{lrrrr}
\hline Trditev & \multicolumn{2}{c}{ 2019/2020 } & & 2020/2021 \\
\cline { 2 - 3 } \cline { 5 - 5 } & UN & VS & & UN \\
\hline Izvedba predmeta je bila boljša, kot ste pričakovali. & 3,5 & 3,5 & & 3,6 \\
Študijske obveznosti so bile obsežne. & 3,2 & 2,7 & & 2,7 \\
Študijske obveznosti so bile zahtevne. & 2,8 & 2,6 & & 2,2 \\
Preverjanje znanja je bilo skladno z učnim načrtom. & 3,7 & 3,5 & & 3,5 \\
Predmet je možno opraviti le s sprotnim delom. & 3,1 & 3,2 & & 3,0 \\
Obveznosti ste opravili brez težav. & 3,0 & 3,1 & & 3,6 \\
\hline
\end{tabular}

H komentarju študenta moramo dodati, da smo pri predmetu imeli študente, ki so se na daljavo šolali zadnje mesece zaključnega letnika srednje šole. Študente smo vprašali, ali bi se, če bi imeli možnost, šolali na daljavo. Na petstopenjski lestvici ( 5 = najvišja ocena) so svoje strinjanje ocenili s 3,6, kar je precej več, kot so bili študentje takšnemu načinu študija naklonjeni leto prej (VS19/20: $M=3,2 ;$ UN19/2O: $M=3,1$ ).

Zadovoljstvo študentov s študijem na U P F M je enako kot pri študentih UN V študijskem letu 2019/2020 (oboji $M=4,3$; VS19/20: $M=$ 3,9).

V študij na U P F M študentje I K T praktikuma 2020/2021 v povprečju vlagajo 23,4 ure na teden, medtem ko so $\mathrm{v}$ študij I K T praktikuma vložili v povprečju po 10,o ure na teden. Iz mnenjskih anket izhaja, da so študentje v opravljanje obveznosti v povprečju vložili 13,8 ure na teden. Tako kot za študente predhodnega leta smo izračunali ponderirano povprečje, pri tem pa upoštevali število študentov, ki so odgovorili na anketo o izvedbi predmeta, ter povprečno število odgovorov v mnenjskih anketah. Povprečna tedenska obremenitev je bila po mnenju študentov 11,7 ure. Upoštevajoč 7-tedensko izvedbo predmeta to pomeni, da je povprečni študent $\mathrm{v}$ opravljanje študijskih obveznosti vložil 82 ur, kar je precej več, kot so vložili študentje v študijskem letu 2019/2020. Delo na daljavo je od študentov torej zahtevalo več dela (slika 6.24), vsaj po njihovem mnenju, niso pa zaradi tega mnenja, da bi bile študijske obveznosti obsežne ali prezahtevne (preglednica 6.4).

Predmet I K T praktikum za študente UN programa se izvaja takoj ob vstopu na fakulteto, zaradi česar študentje na začetku porabijo veliko več časa kot študentje vs programa, za katere se je predmet izvedel šele v 3. kvartalu, ko so se že dobro seznanili s študentskim načinom dela. Delo na daljavo očitno zahteva več dela kot delo v klasični učilnici - primerjava VS 2019/2020 od 4. tedna dalje in izvedba UN 2020/2021 na 


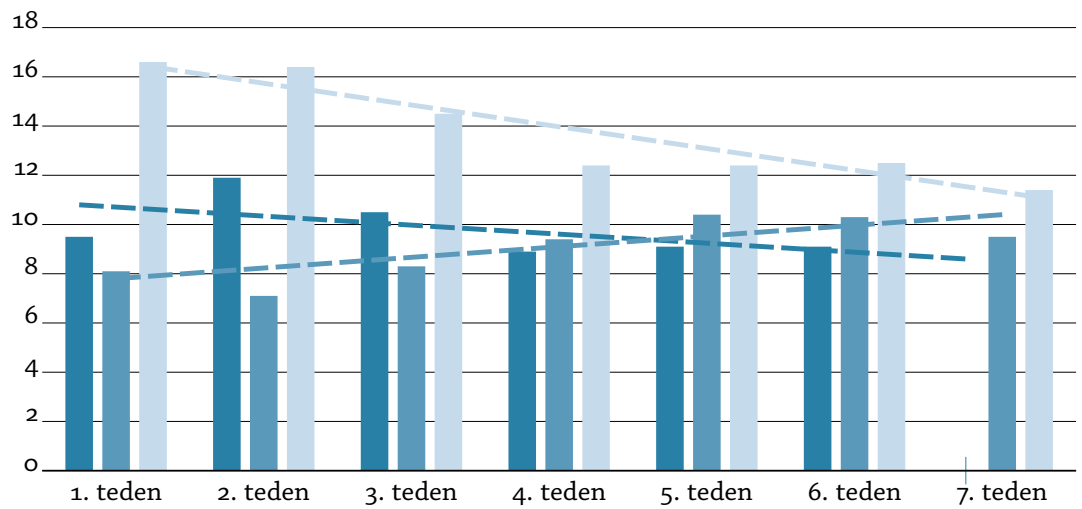

Slika 6.24 Primerjava tedenske obremenitve študentov (temno UN 2019/2020, srednje VS 2019/2020, svetlo UN 2020/2021)

sliki 6.24. Zanimivo pa je, da študentje povečan obseg dela ne občutijo kot breme, kar se kaže tako iz mnenj o obsežnosti in težavnosti študijskih obveznosti kot tudi iz prostih komentarjev v anketi o izvedbi predmeta. Online izvedba predmeta jim je omogočila prilagodljivejši študij pa tudi več prostega časa.

V e-učilnici imamo nameščen vtičnik Dedication tool, ki izkazuje čas, ki so ga študentje preživeli v e-učilnici. Če so študentje U N 2019/2020 e-učilnico uporabljali v povprečju 1.197,67 minut in študentje VS 2019/ 2020 1.102,97 minut, je povprečen študent UN programa v študijskem letu 2020/2021 v e-učilnici preživel kar 2.011,92 minut.

\subsection{Primerjava uspešnosti študentov pri IK T praktikumu}

Pri uspešnosti presojamo tudi opravljanje izpita na daljavo, ki se izvede po zaključku izvedbe predmeta (v t. i. kvartalnem izpitnem roku) (preglednica 6.5). V preglednici 6.5 prikazujemo število študentov, ki so sodelovali pri tedenskih nalogah. Pogoj za pristop k izpitu je bila vsaj polovica doseženih točk pri tedenskih nalogah. K izpitu so tako pristopili le študentje, ki so izpolnjevali pogoj. Pri vs 2019/2O2O in U N 2020/2021 nekateri študentje niso pristopili k izpitu, ker na dan izpita niso mogli izpolniti tehničnih zahtev. Pri tem naj omenimo, da so se izpiti opravljali ob tem, ko so bili doma tudi starši in sorojenci ali pa je bilo v študentski sobi več študentov, čeprav je bilo slednje bolj redko.

Zanimivo je, da bil v programu UN 2020/2021, ko se je predmet v celoti izvajal na daljavo, večji delež študentov, ki so izpolnili pogoj za pristop k izpitu (77,4\%), je bil pa delež študentov, ki so opravili izpit, 
Preglednica 6.5 Primerjava uspešnosti študentov

\begin{tabular}{lllllll}
\hline Program in leto izvedbe & $(1)$ & $(2)$ & $(3)$ & $(4)$ & $(5)$ & $(6)$ \\
\hline UN 2019/2020 & 43 & 28 & 65,1 & 28 & 100,0 & 9,1 \\
VS 2019/2020 & 67 & 42 & 62,7 & 35 & 83,3 & 9,3 \\
UN 2020/2021 & 31 & 24 & 77,4 & 18 & 75,0 & 9,3 \\
\hline
\end{tabular}

OP OM BE Naslovi stolpcev: (1) študentje pri predmetu, (2) pristop k izpitu, (3) delež pristopa (\%), 84) opravili v 1 . kvartalu, (5) delež uspešnosti (\%), (6) povprečna ocena pozitivnih ocen.

nižji. Nižja uspešnost je vezana na obvezno snemanje poteka reševanja; v letu 2020/2021 namreč nekatere izpitne naloge zaradi manjkajočega posnetka niso bile ocenjene.

\subsection{Poslovna informatika}

\section{Uvod}

Predmet Poslovna informatika (vs/U N) se je v obeh starih študijskih programih (VS/U N 2013) izvajal v 1. letniku, pred letom 2013 pa v 2. letniku. Premik v 1. letnik je bil narejen, ker smo želeli študente digitalno opismeniti in pripraviti za nadaljnji študij. Praksa pa je kasneje pokazala, da je razvoj digitalnih spretnosti na začetku študija sicer pametna odločitev, da pa je za razumevanje vsebin s področja poslovne informatike potrebno poznavanje nekaterih temeljnih vsebin s področja poslovnih ved. Zato smo predmet, ob prenovi študijskih programov, razdelili na dva dela - digitalne spretnosti smo združili s študijskimi veščinami (Študijski in I K T praktikum), vsebine poslovne informatike pa razširili $\mathrm{z}$ novimi vsebinami in jih umestili med obvezne predmete 2. letnika. V nastajanju je tudi prenovljena skripta, ki pa zaradi časovne stiske $v$ študijskem letu 2020/2021 še ni popolnoma zaključena. Delovna različica skripte je tako kombinacija vsebin starega in prenovljenega predmeta.

Predmet Poslovna informatika (V s/U N 2019) se je tako prvič izvedel v študijskem letu 2020/2021. Do sedaj je šlo za enega izmed zahtevnejših predmetov, kar je sicer glede na generacijo, ki odrašča in živi s tehnologijo, nerazumljivo. Na zahtevnost kaže nizek delež študentov, ki je študijske obveznosti predmeta opravil že v kvartalu (preglednica 6.6). Izpitna ocena je bila sestavljena iz ocene tedenskih nalog (30\%), testa I K T-pismenost ${ }^{18}(20 \%)$ in dveh kolokvijev (50\%).

Vse izvedbe, predstavljene v preglednici 6.6, je izvajal isti učitelj (av-

\footnotetext{
${ }^{18}$ Vsebine so se v programu iz leta 2019 prenesle v I K T praktikum.
} 
Poslovna informatika 6.4

Preglednica 6.6 Uspešnost študentov Poslovne informatike po letih

\begin{tabular}{lrrrrrrrr}
\hline Študijsko leto & \multicolumn{3}{c}{ Visokošolski } & & \multicolumn{3}{c}{ Univerzitetni } \\
\cline { 2 - 3 } \cline { 7 - 8 } & $(1)$ & $(2)$ & $(3)$ & & $(1)$ & $(2)$ & $(3)$ \\
\hline $2018 / 2019$ & 78 & 21 & 26,9 & & 33 & 13 & 39,4 \\
$2017 / 2018$ & $*$ & $*$ & $*$ & 36 & 17 & 47,2 \\
$2016 / 2017$ & 78 & 29 & 37,2 & & 26 & 15 & 57,7 \\
$2015 / 2016$ & 74 & 23 & 31,1 & & 30 & 14 & 46,7 \\
\hline
\end{tabular}

OPOMBE Naslovi stolpcev: (1) število študentov, (2) število pozitivnih, (3) delež uspešnosti (\%). * Drug izvajalec.
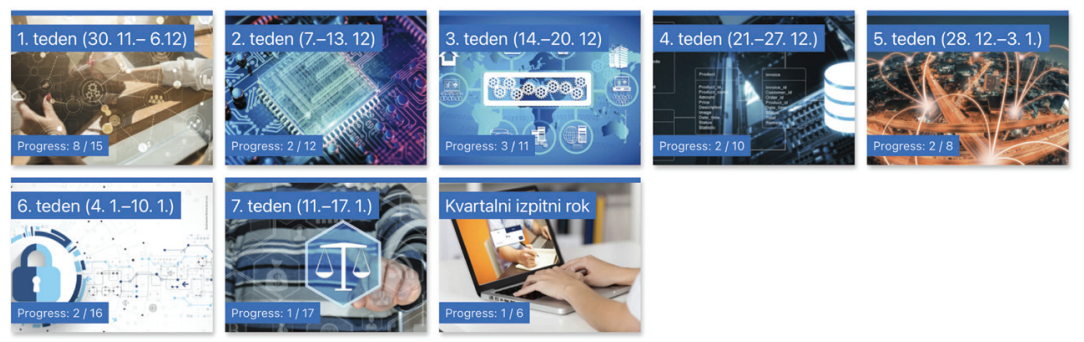

Slika 6.25 Ureditev e-učilnice - Poslovna informatika (UN 2019)

torica monografije), na isti način in $z$ istimi vsebinami. Vse izvedbe so bile izvedene na kombiniran način, kar pomeni, da so bili $\mathrm{v}$ živo izvedeni predavanja in vaje, študentje pa so v spletnih učnih okoljih (e-učilnica, Googlovi dokumenti) pripravljali domače naloge. Večji del nalog je bilo skupinsko delo. $V$ preglednici 6.6 pod številom pozitivnih predstavljamo le študente, ki so vse obveznosti predmeta opravili v kvartalu, s sprotnim delom.

\section{Izvedba predmeta $v$ študijskem letu 2020/2021}

Prenovljen predmet Poslovna informatika je po obsegu K T enak - pred in po prenovi ima šest K T. Povečalo pa se je število ur. Predmet se je po programu iz leta 2013 izvajal s 30 urami predavanj, 10 urami vaj in 20 urami drugih oblik študija (e D O š). Prenovljen predmet ima 35 ur predavanj in 35 ur vaj, s tem da učitelj del vaj lahko izvede na e-način.

Predmet na UN programu se je izvajal v 2. kvartalu (slika 6.25), na VS programu pa v 3. kvartalu. Obe izvedbi sta bili na daljavo.

Glede na epidemiološko sliko, ki je bila poznana ob začetku študijskega leta, in predviden tok dogodkov je bil predmet že v začetku načrtovan za e-izvedbo. Ta je bila kompromis med zahtevami UP, da se pre- 
Slika 6.26

Primer

tedenske ureditve

predmeta

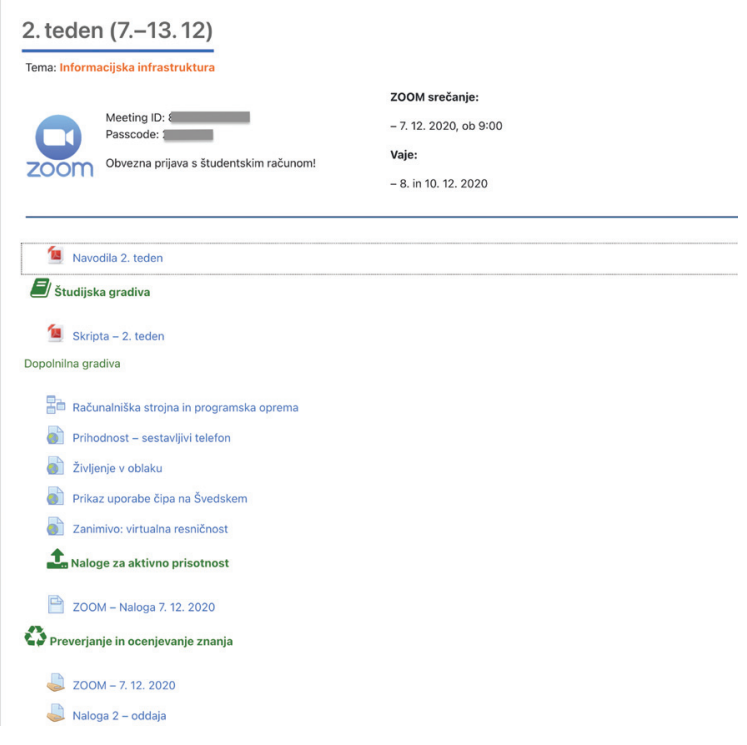

davanja izvedejo prek videokonferenčnega sistema zooM, in presoje ter izkušenj izvajalke predmeta $\mathrm{v}$ zvezi z izvedbo pedagoškega procesa na daljavo.

Vsebine predmeta so bile razdeljene na sedem vsebinskih sklopov (tem/tednov). Naslovi tem in datumi vseh srečanj so bili objavljeni vnaprej, medtem ko so se gradiva in tedenska navodila ter obveznosti študentov odpirali sproti. ${ }^{19}$ Predmet je bil zasnovan na način, da so študentje s sprotnim delom opravili vse študijske obveznosti. Končna ocena je bila sestavljena iz ocene tedenskih (domačih) nalog (30\%), aktivne prisotnosti na zooM-ovih srečanjih (20\%) in ocene dveh kolokvijev (50\%).

\section{Sinhrona izvedba kontaktnih ur (predavanja)}

Teden se je začel s predavanjem prek zoo M-a. Lanskoletne osebne izkušnje izvajalke predmeta pa tudi izkušnje drugih učiteljev $\mathrm{z}$ uporabo videokonferenc - pasivnost udeležencev, opravljanje drugih dejavnosti med predavanji, fizična odsotnost študenta itn. - so narekovale uvedbo t. i. aktivne udeležbe, ki je vplivala tudi na končno oceno predmeta. Ni bilo dovolj, da so se študentje vključili v zoom. Predavanju so morali

\footnotetext{
${ }^{19}$ Vsebine za prihodnji teden so se odprle v soboto ali v nedeljo, medtem ko se je teden začel s ponedeljkom.
} 


\section{Breakout Room Assignment 8 rooms, 33 participants}

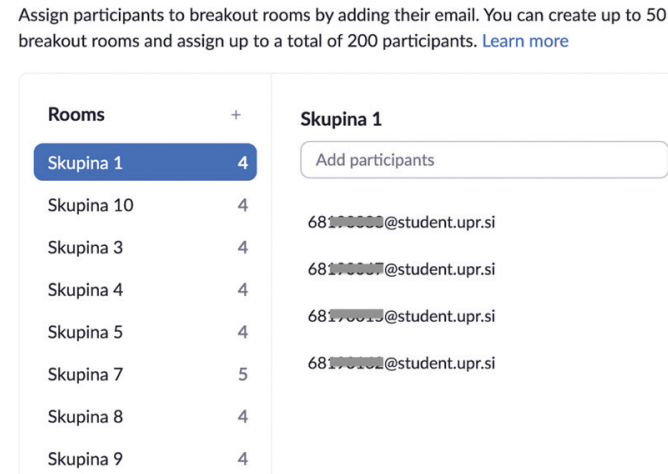

Slika 6.27

Prednastavljene

skupine za skupinsko

delo v ZOOM-u

slediti na način, da so pisali zapiske. Le-ti so morali biti, razen izjem, napisani na roko, saj raziskave dajejo prednost tako pisanim zapiskom pred zapiski na računalniku (Mueller in Oppenheimer 2014). Študentje so po predavanju zapiske $\mathrm{v}$ obliki slike, pretvorjene v PDF dokument (dodatna vaja $\mathrm{z}$ različnimi formati datotek), oddali v e-učilnico. Med predavanjem smo študente razvrstili v skupine, ki so jih oblikovali na začetku izvedbe predmeta v e-učilnici. Seznam skupin in razporeditev študentov po skupinah smo naložili v ZOOM, tako da je vsakokratno odpiranje skupinskega dela (zoOM-ova zmogljivost Breakout rooms) študente samo razporedilo $v$ vedno iste skupine. Takšna vnaprejšnja naložitev skupin ${ }^{20}$ in članov skupine (slika 6.27) je izvedljiva le, če se študentje v ZOOM prijavljajo prek vedno istih e-poštnih računov. V našem primeru so bili to zo o M-ovi študentski računi in določitev, da je le takšna prijava sprejemljiva. Študenta, ki se ni pravilno prijavil, zo o Mi spustil v spletno predavalnico.

V ločenih skupinah so študentje opravljali različne naloge, povezane s predstavljeno snovjo. $\mathrm{Na}$ ta način smo skušali teorijo čim bolj povezati s prakso, predvsem pa študentom, ki so bili med seboj oddaljeni,

${ }^{20}$ Prednaložitev poteka prek datoteke csv, kjer sta dva stolpca: Pre-assign Room Name in E-mail Adress. V prvi stolpec vnesemo ime skupine, $v$ drugem so pa e-poštni naslovi udeležencev (študentov). Seveda se mora študent prijaviti z e-poštnim naslovom, ki je povezan s skupino, sicer ga sistem ne bo samodejno razvrstil. 


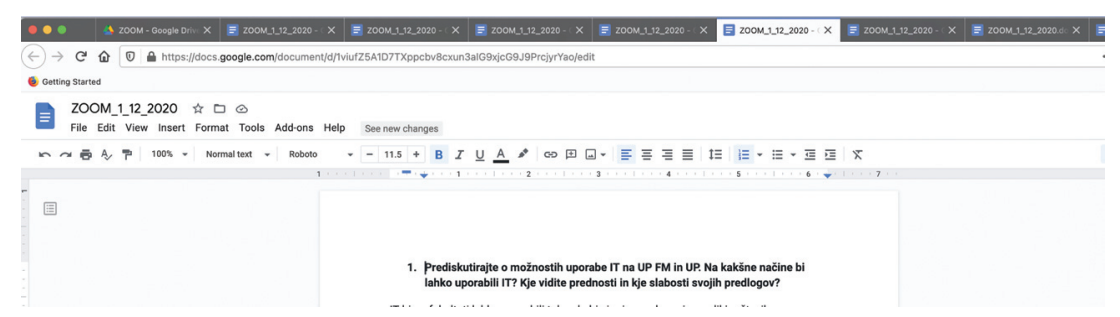

Slika 6.28 Skupinsko delo v ločenih skupinah

omogočiti več medsebojne komunikacije. Pri predmetu UN je bilo npr. 33 študentov in nemogoče bi bilo, da bi med seboj razpravljali. Tako je diskusija potekala v skupinah, ki so jih tvorili štirje študentje. Zaradi neparnega in s številom štiri nedeljivega števila študentov je bilo $\mathrm{v}$ eni skupini izjemoma pet študentov. Delo študentov v skupinah je bilo podprto z Googlovimi dokumenti, v katere so zapisovali rešitve naloge, svoje ugotovitve ali zaključke diskusije. Na začetku se je izvajalka predmeta premikala iz sobe $v$ sobo, kasneje pa je njihovo delo raje spremljala prek Googlovih dokumentov. V brskalniku je odprla deset zavihkov z dokumenti vseh skupin in delo po skupinah pregledovala s pomikom od zavihka do zavihka. V kolikor je opazila, da skupina ni aktivna, je vstopila v videokonferenčno sobo skupine in preverila, ali so kakšne težave v razumevanju zadolžitev. Študentje so jo lahko v vsakem trenutku tudi poklicali na pomoč. Zmogljivost dela v ločenih skupinah je nedvomno nadvse uporabna zmogljivost videokonferenčnega sistema zooM pri sinhronem delu na daljavo, ki je navdušila učitelje in študente.

Predstavitev vsebin predmeta smo posneli, povezavo do posnetka pa prek e-učilnice delili s študenti. Posnetek je bil na razpolago do konca delovnega tedna, tako da so si ga študentje lahko kasneje ponovno ogledali. Študentje so za aktivno udeležbo na srečanju morali do 20:00 istega dne oddati sliko zapiskov in kopijo nalog (prenos Googlovega dokumenta na računalnik in oddaja $\mathrm{v}$ predvidenem formatu), ki so jih $\mathrm{v}$ skupini delali na Googlovem dokumentu. Študentje, ki se zaradi različnih vzrokov niso mogli udeležiti dopoldanskega predavanja, so si predavanje lahko ogledali kasneje, vmes izdelali zapiske in sliko zapiskov oddali v e-učilnico. Študentje so za aktivno prisotnost prejeli do 2 točki. V kolikor se predavanja niso udeležili, so pa zapiske pripravili ob ogledu posnetka predavanja, so prejeli 1,5 točke.

Pri izvedbi srečanj prek zo o M-a lahko izluščimo nekaj koristnih priporočil: 
- zo o M-ovo srečanje je bilo, kot smo že predstavili, vedno na istem naslovu - ista spletna predavalnica.

- V zoom se učitelj vključi vsaj 15 minut pred uradnim začetkom. Uporabniško izkušnjo lahko izboljša na način, da ob vključitvi v z O O M-ovo spletno predavalnico doda prijetno glasbo s svojega računalnika in deli naslovno prosojnico ob napovedi začetka predavanja. Kamera in mikrofon na učiteljevem računalniku sta izključena.

- zoom je koristno izvajati z dveh računalnikov z dveh računov - enkrat v vlogi učitelja, drugič v vlogi udeleženca. Takšen način olajša pregled nad izvedbo, odpade pa tudi preverjanje, ali študentje vidijo deljeno prosojnico, oziroma prikaz aktivnosti na računalniku učitelja. Nadzorni računalnik je lahko tudi tablica ali telefon. V praksi smo uporabljali (namizni) računalnik z dodatnim zaslonom, tako da so bili študentje vidni na enem zaslonu, predstavitev pa na drugem. Ob tem pa je potrebna še dodatna naprava (običajno prenosnik) za prikaz udeleženčevega pogleda.

- Učitelj se s kamero in z mikrofonom vključi nekaj minut pred začetkom. To je za udeležence pomenilo, da se predavanje začenja.

- Vsako srečanje se je začelo $\mathrm{z}$ obvezno vključitvijo vseh kamer in mikrofonov ter s kratkim sproščujočim klepetom s študenti. $\mathrm{Na}$ ta način smo ohranili osebno povezanost s študenti, ti so se pred predavanjem sprostili in psihično pripravili na delo. Pogosto smo jih tudi vzpodbudili, da se pretegnejo, razgibajo vratne mišice ter dlani. zоom tudi ob vseh vključenih kamerah in mikrofonih ni povzročal težav. Vsa komunikacija je potekala nemoteno.

- Študentom smo na prvem srečanju pokazali, kako si uredijo sliko profila, tako da je bila slika študenta vidna tudi, ko je bila kamera izključena. Dejstvo je, da vsi nimajo dovolj hitrega interneta in jim je vklop kamere lahko povzročal težave. Izvajalka predmeta do interneta dostopa prek navadne telefonske linije AD S L (parice) in z izvedbo predavanj ni imela težav.

- Pri delu študentov v ločenih skupinah smo študente spodbudili, da vključijo kamero in med delom tudi malo poklepetajo. Zato smo tudi prenehali obiskovati ločene skupine in se v sobe vključevali le po zahtevi ali potrebi. Epidemija je onemogočila fizično druženje študentov, zato se nam je takšen pristop zdel smiseln. Študente smo tudi drugače vzpodbujali, naj se družijo prek z o o M-a, saj smo 
Da bomo lažje prebrodili lockdown - priključimo se vodenemu aktivnemu odmoru za vse zaposlene in študente (od ponedeljka do petka ob 13:15).

Vadba na kanalu projekta Star-Vital

For an easier lockdown, join the guided active breaks for all employees and students from Monday to Friday at 13:15.

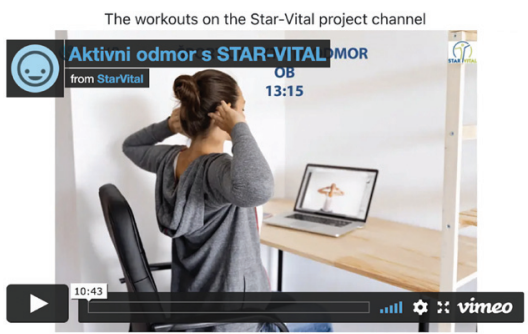

Slika 6.29 Vabilo k aktivnemu odmoru v e-učilnici UP F M

se zavedali posledic, ki jih mladim prinaša odsotnost fizičnih stikov.

- Srečanje smo zaključili z obvezno vključitvijo kamer in mikrofona in željami po preživljanju lepega preostanka dneva in skrbi za zdravje. Skrb za zdravje je bila na prvem mestu, zato smo študente na vsakem srečanju na to tudi opomnili, ne samo na upoštevanje priporočil stroke glede varovanja v času epidemije. Spodbujali smo jih $\mathrm{k}$ skrbi za lastno zdravje in gibanje. $\mathrm{V}$ ta namen smo na prvo stran e-učilnice dali tudi povezavo do aktivnega odmora, ki so ga $\mathrm{v}$ okviru projekta Star-Vital ${ }^{21}$ pripravljali na U P F VZ (slika 6.29).

\section{Asinhrona izvedba kontaktnih ur (vaje)}

Za izvedbo vaj smo pripravili naloge, ki so bile povezane s tedensko temo. Študentje so tedenske naloge reševali prek e-učilnice ali Googlovih dokumentov. Glede na veliko število ur, ki naj bi se izvajale prek zo oM-a, smo jim ponudili alternativo - skupinske naloge lahko delajo prek študentskih z o o M-ovih srečanj, sinhrono, ali pa jih opravijo asinhrono do konca tekočega tedna. Glede na to, da so naloge potekale na način, ki je omogočal spremljanje nastanka naloge, je izvajalka predmeta naloge sproti pregledovala in študente usmerjala k pripravi nalog skladno z navodili. Na ta način so študentje že med izvedbo dobili povratno informacijo, so jo pa vsi dobili tudi ob oddaji in oceni naloge. Ne samo da je pravočasna povratna informacija učitelja ključna za uspe-

\footnotetext{
${ }^{21}$ Glej https://www.star-vital.si/.
} 
šen študij (Marentič-Požarnik 200o, 563; Wiliam 2011; Jackel idr. 2017; Brown in Glover 2019), takšen način dela je bil med študenti zelo dobro sprejet in pohvaljen $\mathrm{v}$ mnenjskih anketah.

Glede na to, da smo študente usmerjali k sprotnemu študiju - aktivni prisotnosti na predavanju -, smo tedenske obveznosti dopolnili še $s$ kratkim testom znanja. Tega so sestavljala naključna vprašanja iz obsežne zbirke vprašanj (skupaj jih je bilo pripravljenih čez 200). Vprašanja so bila izbirnega tipa, $z$ eno ali več možnimi rešitvami, ali pa so študentje izbirali le med Drži/Ne drži.

Test znanja se je odprl v petek, ob 8:oo, študent ga je lahko rešil le enkrat, in sicer do sobote do 20:00. Študentje so čas reševanja prilagodili svojim razmeram doma (prostor, čas). Test znanja se je odprl v varnem oknu brskalnika. Vprašanja so se prikazovala v pomešanem zaporedju, študent pa se je lahko pomikal le naprej. Študentje so v tedenskih odzivih sicer imeli pripombe, da se ne morejo vračati na vprašanja, vendar je bil takšen premik po testu pripravljen v izogib goljufanju in študentje so bili na to tudi posebej opozorjeni. Čas reševanja je bil omejen. Vsak test je bil vreden do pet točk, ocene testov pa so se evidentirale pri tedenskih nalogah. Zaradi odpiranja testov znanja v varnem oknu brskalnika, ki temelji na programu Safe Exam Browser (S E B), ${ }^{22}$ smo v prvem tednu naredil vzorčen preizkusni test, na katerem so študentje preverili ustrezno namestitev programa SE B in delovanje računalnika. $\mathrm{Z}$ reševanjem testov kasneje ni bilo težav.

\section{Preverjanje in ocenjevanja znanja na daljavo}

Tedenske naloge so praktično naravnane, saj z njimi povezujemo teorijo s prakso. Teoretično znanje, predstavljeno na predavanjih in v skripti, pa preverim $z$ dvema kolokvijema. Prvega študentje pišejo $v$ četrtem tednu izvedbe, drugega pa v zadnjem (sedmem) tednu. Kolokvija na končno oceno izpita vplivata s $50 \%$. Opravljanje izpita prek kolokvijev je namenjeno le študentom, ki študijske obveznosti opravljajo s sprotnim delom. Študent tako h kolokvijema pristopi le, če dosega vsaj polovico točk tedenskih nalog. Študentje, ki iz različnih razlogov ne morejo slediti tekoči izvedbi v kvartalu, svoje obveznosti opravijo v izpitnem obdobju. Takšen izpit, poleg teoretične snovi, vsebuje še nekaj praktičnih nalog, ki so bile vključene v tedenske naloge. Študentje običajno svoje študijske obveznosti lažje opravijo s sprotnim delom, pa čeprav je uspeš-

${ }^{22}$ Glej https://safeexambrowser.org/download_en.html. 
nost ob zaključku kvartala v programu vs/U N 2013 (preglednica 6.6) nizka. Kasnejše opravljanje izpitov je za študente težje in izpit opravljajo po večkrat. Težave jim dela predvsem reševanje praktičnih nalog (npr. izdelava procesnega in E R-diagrama enostavnega primera). V programu VS/UN 2013 so študentje k izpitu lahko pristopili le, če so imeli opravljen I K T-test, kar je v novem programu premaknjeno v Študijski in IK T praktikum.

Kolokvija pri Poslovni informatiki se pišeta klasično - po 12 odprtih vprašanj na kolokvij. Čas reševanja je omejen na 45 minut. Za izvedbo kolokvija na daljavo smo se odločali med Moodlovim kvizom in platformo exam.net. $V$ poletnem in jesenskem izpitnem obdobju 2020 smo izpite iz Poslovne informatike za prejšnje generacije izvedli prek Moodlovega kviza in uporabo SE B-a, nadzor pa izvajali prek zooM-a. Pri preverjanju tehnologij v študijskem letu 2020/2021 pa smo opazili težave pri sočasni uporabi Moodlovega kviza s SE B-om in nadzora prek z O OM-a. Uporabnikom računalnikov Apple z operacijskim sistemom Mac OSX se ob zagonu SEB-a zapre program zOOM, kar onemogoči nadzor nad izvedbo izpita. Zato smo se odločili, da kolokvije in izpite izpeljemo prek platforme exam.net, prek katere je potek izpita še najpodobnejši klasični izvedbi. Študentje navodila za kolokvij/izpit prejmejo v obliki dokumenta P D F, ki ga učitelj naloži na platformo exam.net (lika 13).

Podobno kot pri I K T praktikumu smo tudi za izvedbo kolokvijev (izpitov) pri Poslovni informatiki pripravili izpitni protokol, ki podrobno določa opremo, potrebno za opravljanje izpita na daljavo (slika 6.30), obveznosti študenta pred izpitom ter njegove dolžnosti med izvedbo in ob oddaji izpita.

Predpriprava na kolokvij/izpit se veliko ne razlikuje od predpriprav pri I K T praktikumu. Študent namreč mora:

- posodobiti programsko opremo; glede na to, da izpit poteka po računalniku, sočasno pa se bo uporabljal tudi pametni telefon, mora posodobiti operacijski sistem in zo o M-ovo aplikacijo na obeh napravah;

- poskrbeti, da ima naloženo zadnjo različico SE B-a na računalniku; $v$ ta namen študentom pred izpitom ponudimo možnost testiranja opreme na vzorčnem izpitu, do katerega je povezava v e-učilnici (slika 6.31);

- zagotoviti miren in prazen prostor ter prazno delovno površino 


\section{PROTOKOL OPRAVLANJA IZPITA NA DALJAVO}

Poslovna informatika (kolokvij/izpit)

Kolokvij/izpit opravljate prek platforme exam.net ter video konferenčnega sistema ZOOM (nadzor nad opravljanjem izpita). Reševanje izpita morate posneti na svoj pametni telefon, povezavo do posnetka pa kopirati v e-učilnico (Kolokvij/lzpit - oddaja ZOOM povezave in vpis ocen). Kolokvij/izpit brez posnetka ne bo ocenjen!

Potrebna oprema za opravljanje e-izpita:

- Računalnik s kamero za opravljanje e-izpita. Na računalniku je nameščen ZOOM ter SEB, ki ga naložite s spletne strani exam.net (zadnjo verzijo naložite kakšen dan pred izpitom in preizkusite reševanje vzorčnega izpita - podatki so v e-učilnici). Svetujem, da računalnik na novo zaženete kakšne pol ure pred kolokvijem/izpitom in ne odpirate nepotrebnih programov. Za opravljanje kolokvija/izpita boste potreboval le ZOOM in brskalnik za povezavo do izpitne platforme exam.net. $V$ kolikor prenosni računalnik nima polne baterije ga priključite na napajanje (priporočeno!).

- Pametni telefon $s$ priključenim polnilcem in nastavitvijo na Ne moti«. Na telefon namestite ZOOM. Telefon boste uporabili za snemanje reševanja izpita, zato priskrbite stojalo ali kakšno drugo oporo (knjiga, ipd), ki bo telefon podprla na način, da bo snemal reševanje izpita. Videti se mora miza, tipkovnica, študent in del zaslona (glej sliko).

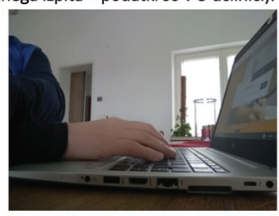

Slika 6.30 Izpitni protokol pri Poslovni informatiki

Slika 6.31

Ureditev e-učilnice za kvartalni izpitni rok

\section{Kvartalni izpitni rok}
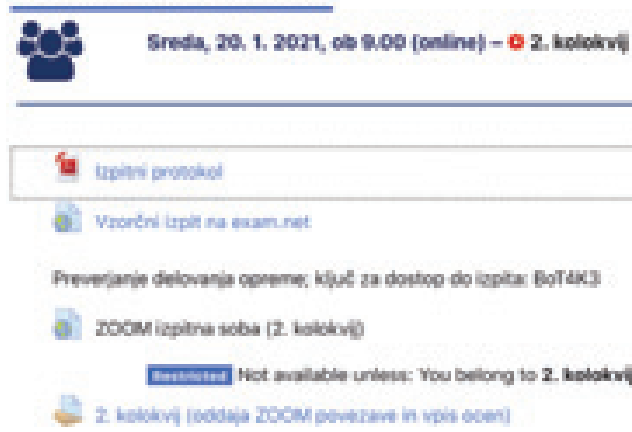

in pripraviti identifikacijski dokument (študentsko izkaznico), na mizi ima lahko manjši listek, na katerega bo zapisal ključ za dostop do izpita.

Pred 1. kolokvijem smo celotni izpitni protokol testirali s študenti, kar se je pokazalo za koristno. Študentje tako preverijo delovanje tehnologije, $\mathrm{z}$ učiteljem pa rešijo vse morebitne dileme. Za 2. kolokvij testiranje ni bilo potrebno, smo pa študente vseeno napotili k samopreverjanju delovanja računalniške opreme (slika 6.31).

Za kolokvij/izpit smo odprli ločeno, t.i. zo o M-ovo izpitno sobo, do katere so povezavo videli le študentje, ki so imeli pravico dostopa do kolokvija oziroma izpita.

Študent se prijavi v zooM-ovo izpitno sobo in počaka na učiteljeva navodila. Po pozivu učitelja začne s snemanjem poteka izpita na pame- 
Slika 6.32

Zajem slike s

pametnega telefona

med izpitom

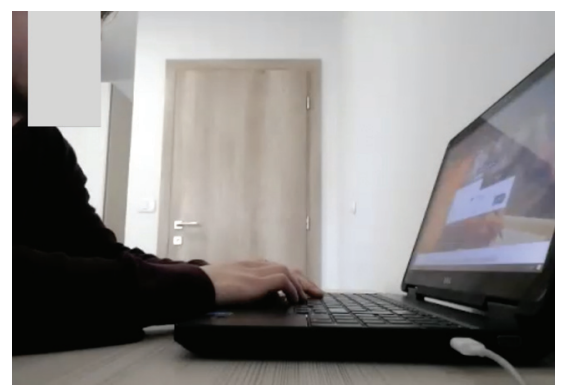

tni telefon. Snemanje se izvede $\mathrm{z}$ uporabo študentovega $\mathrm{z} O \mathrm{O} \mathrm{M}$-ovega računa in zagonom osebnega $\mathrm{zOOM}$-ovega srečanja (angl. personal meeting). Študent najprej (v izogib uporabi nedovoljenih pripomočkov v prostoru - plakati, nalepljeni "plonklistki« ipd. - ali prisotnosti osebe v prostoru) naredi posnetek svojega delovnega prostora $\mathrm{v}$ razponu $360^{\circ}$, nato pa telefon odloži na desni rob mize, tako da je viden računalnik z zaslonom in del študentovega telesa (slika 6.32).

Učitelj študente usmeri na exam.net in po zo o M-ovem klepetu sporoči ključ za dostop do izpita. Študentje si lahko ključ zapišejo na papir, saj ko se zažene SEB, dostop do klepeta ni več mogoč. Učitelj prek platforme preveri, ali so vsi študentje vstopili v exam.net, in nastavi čas reševanja. Le-ta se študentom izpiše na zaslonu. Ko se reševanje izpita začne, vsa komunikacija med študenti in učiteljem poteka le prek platforme exam.net (slika 4.10), kar ne moti poteka izpita. Komunikacijski kanal platforme exam.net predstavlja veliko prednost pred klasično izvedenimi izpiti, ko so različna vprašanja študentov ali opozorila in komentarji učitelja moteči.

Študentje med izpitom ne smejo uporabljati slušalk in mikrofona, tako da je slišen zvok iz prostora. Zaradi interferenc mora študent na telefonu izključiti izhod zvoka, vhod pa je vključen. Ko zaključi z reševanjem (odda izpit $v$ exam.net), telefon približa obrazu in pokaže še svoj identifikacijski dokument. Posnetek se shrani na zo o M-ov oblak, študent pa v e-učilnico odda povezavo do zo o M-ovega videoposnetka oziroma kopira vsebino zo oM-ovega e-poštnega obvestila, ki ga dobi na svoj šolski e-poštni naslov, kot so to naredili študentje pri I K T praktikumu (slika 6.22). Učitelj oceni le naloge, ki so opremljene s povezavo do videoposnetka.

Čeprav učitelj potek izpita spremlja na zo o M-u, pa je študentov videoposnetek dopolnitev nadzora nad potekom izpita. Na eni strani posne- 
Preglednica 6.7 Uspešnost študentov Poslovne informatike (2020/2021)

\begin{tabular}{llllllr}
\hline Študijski program & $(1)$ & $(2)$ & $(3)$ & $(4)$ & $(5)$ & $(6)$ \\
\hline Univerzitetni & 37 & 32 & 27 & 84,4 & 27 & 100,0 \\
Visokošolski & 47 & 33 & 30 & 90,1 & 27 & 90,0 \\
\hline
\end{tabular}

OP ОМ BE Naslovi stolpcev: (1) seznam - Š Is (vključuje tudi študente, ki se ne vključijo v redno izvedbo - nimajo namena opravljati izpita, pavzirajo ali pa so še starega programa in morajo za priznanje izpita opraviti obveznosti izven redne izvedbe), (2) število študentov, (3) pristop na 2. kolokvij, (4) delež pristopov (\%), (5) število pozitivnih, (6) delež uspešnosti (\%).

tek pomaga študentu v primeru, da bi prišlo do prekinitve zo o M-a na računalniku, na katerem poteka reševanje izpita, na drugi strani pa študent dokaže, da je izpit reševal brez tuje pomoči, kar je pogoj za verodostojnost izpita. Prek videoposnetka se izvede tudi preverjanje identitete študentov. Preverjanje identitete na začetku izpita je časovno zamudno, zato jo pri izpitih iz Poslovne informatike preverjamo na koncu, prek študentovega videoposnetka. Po vpisu ocene učitelj študenta prek eučilnice obvesti o doseženi oceni in ga usmeri v brisanje videoposnetka, saj le-ta ni več potreben.

\section{Odziv študentov}

Predmet Poslovna informatika se je za redne študente UN programa izvedel v 2. kvartalu, za študente v s programa pa v 3. kvartalu. Študente v e-učilnico vnesemo na osnovi seznama študentov iz šis-a (preglednica 6.7). Na seznamu študentov so tudi tisti, ki pavzirajo ali pa predmeta ne želijo opravljati v tekočem kvartalu. Takšne študente po predhodnem večkratnem obveščanju konec drugega tedna izvedbe izključimo iz predmeta. Tako v predmetu ostanejo le študentje, navedeni $\mathrm{v}$ stolpcu »Število študentov« v preglednici 6.7. Kot smo omenili, so študentje tedensko aktivno sodelovali pri zoo M-ovih predavanjih, poleg tega pa še tedensko opravljali različne skupinske in individualne naloge. Na oba kolokvija so lahko pristopili le tisti, ki so pri tedenskih nalogah dosegli vsaj 50 \% možnih točk. Na vs programu je bilo takšnih 90,1\%, na UN programu pa 84,4 . So pa vsi študentje UN programa, ki so imeli pravico pristopa $\mathrm{k}$ 2. kolokviju, tega tudi opravili, s tem pa tudi vse obveznosti predmeta. Na vs programu je bila uspešnost nekoliko nižja (90\%), vendar še vedno veliko višja od uspešnosti predhodnih izvedb predmeta (preglednica 6.6). Uspešnost je bila presenečenje tudi za izvajalko predmeta. Namensko smo pripravili primerjavo izvedb iste izva- 
6 Evalvacija izvedb predmetov s področja poslovne informatike

Preglednica 6.8 Odziv študentov na anketo o izvedbi predmeta

\begin{tabular}{lrrr}
\hline Študijski program & Število študentov & Število odgovorov & Delež odziva (\%) \\
\hline Univerzitetni & 32 & 23 & 71,9 \\
Visokošolski & 33 & 26 & 78,8 \\
\hline
\end{tabular}

Preglednica 6.9 Z Z oM-ova srečanja (mnenja študentov)

\begin{tabular}{lrr}
\hline Trditev & U N & VS \\
\hline ... le zato, ker je bilo to potrebno. & 2,0 & 1,9 \\
... ker so bila srečanja koristna. & 3,4 & 3,5 \\
... ker bi se brez srečanj težko vsega naučili. & 3,1 & 3,1 \\
$\ldots$ so bila nekoristna. & 1,3 & 1,4 \\
\hline
\end{tabular}

jalke, kar pomeni, da gre za isti način predstavitve vsebin, isto zahtevnost predmeta kot tudi enakovreden način ocenjevanja pisnih izdelkov in kolokvijev.

Študentje Poslovne informatike so, tako kot študentje IKT praktikuma, med izvedbo predmeta tedensko podali mnenje o delu v preteklem tednu, na koncu pa so izpolnili še anketo o izvedbi predmeta. Odzivnost je bila nad 70\% (preglednica 6.8).

Tako kot pri I K T praktikumu so študentje podali mnenja o razlogih za vključevanje v z o o M-ovega srečanja (preglednica 6.9). Vsa strinjanja s postavljenimi trditvami so izražali na štiristopenjski lestvici (oceni 1 in 2 predstavljata nestrinjanje $s$ trditvijo, 3 in 4 pa strinjanje), tako da povprečne ocene pod 3 izražajo nestrinjanje, nad 3 pa strinjanje s postavljeno trditvijo.

Mnenja študentov v s in U N programa se bistveno ne razlikujejo. Študentje so ZO OM-ova predavanja obiskovali, ker so bila koristna (MUN $=3,4, \mathrm{MVS}=3,5$ ) in ker bi se brez njih težje naučili vse potrebno za izpit ( $M=3,1$ za UN in Vs program). Predavanja so se snemala na $\mathrm{ZOOM}-\mathrm{ov}$ oblak, posnetki pa so bili prek e-učilnice študentom dostopni do konca delovnega tedna. Študentje obeh programov so uporabnost posnetkov na štiristopenjski lestvici ocenili s povprečno oceno 3,7 in s tem potrdili našo odločitev o snemanju ter deljenju povezav do posnetkov za kasnejši ogled. Posnetki so namreč vsem, ki se niso mogli udeležiti z O O M-ovih srečanj, omogočali ogled predavanja, kasneje pa tudi pridobitev večjega dela točk za aktivno udeležbo na predavanju $(1,5)$. Aktivna udeležba na z O OM-ovem predavanju je študentom sicer prinesla do dve točki.

Študentje so izrazili tudi mnenje o strinjanju s trditvami o gradivih, 
Preglednica 6.10 Primerjava mnenj o gradivih

\begin{tabular}{lcc}
\hline Trditev & U N & VS \\
\hline Gradiva so razumljiva. & 3,6 & 3,7 \\
Gradiva so nazorna. & 3,5 & 3,7 \\
Dodatna gradiva so bila uporabna. & 3,1 & 3,4 \\
Gradiva ste natistnili. & 3,1 & 2,6 \\
Gradiva ste uporabljali na telefonu. & 1,7 & 2,2 \\
\hline
\end{tabular}

Preglednica 6.11 Primernost študijskih obveznosti

\begin{tabular}{lcc}
\hline Trditev & UN & VS \\
\hline ZOOM - pisanje zapiskov predavanj & 3,3 & 3,3 \\
ZOOM - delo v ločenih skupinah & 3,4 & 3,5 \\
E-testi v e-učilnici & 3,3 & 3,2 \\
Sodelovalno delo prek foruma v e-učilnici & 3,0 & 3,5 \\
Sodelovalno delo prek Googlovih dokumentov & 3,4 & 3,7 \\
Izdelava spletne strani & 3,2 & 3,3 \\
Tedenske skupinske naloge & 3,5 & 3,5 \\
\hline
\end{tabular}

katerih večji del je bil prenovljen (preglednica 6.10).

Gradiva (skripta) so bila objavljena v obliki formata P D F, vsak teden le vsebina teme tedna. Študentje UN programa so si gradiva natisnili $(M=3,1)$, medtem ko je bilo tiskanja med študenti vs programa veliko manj $(M=2,6)$. Razlika med obema skupinama je še pri načinu uporabe gradiv - dostop do gradiv prek telefona. Tretjina študentov (34,6\%) vs programa je gradiva uporabljala na mobilnih (pametnih) telefonih. V skupini U N študentov sta takšna študenta le dva. So bila pa gradiva razumljiva in nazorna $(M \geq 3,5)$ (preglednica 6.10).

$\mathrm{Z}$ anketo smo preverili primernost različnih obveznosti, ki so jih študentje opravljali tedensko. Presoja je potekala na že predstavljeni štiristopenjski lestvici. Študentje so vse tedenske obveznosti dobro sprejeli in ocenili, da so bile vse primerne $(M \geq 3,0)$ (preglednica 6.11).

Čeprav so bile študijske obveznosti zahtevne $(M=3,0)$ in obsežne ( $M U N=3,2$ in MVS $=3,4)$, so jih študentje opravili brez težav ( $M U N=$ $3,3$ in MVS $=3,4)$. K temu so nedvomno prispevali razumljiva navodila $(\mathrm{MUN}=3,4$ in MVS $=3,5)$ in jasna predstavitev študijskih obveznosti $(\mathrm{MUN}=3,7$ in MVS $=3,8)$ (preglednica 6.12).

Med cilji predmeta je med drugim zapisano, da bodo študentje izboljšali uporabo IK T in razvili zavedanje o izzivih, povezanih $\mathrm{z}$ njeno uporabo, kar smo vključili tudi v anketo o izvedbi predmeta (pregled- 
Preglednica 6.12 Zahtevnost študijskih obveznosti

\begin{tabular}{lcc}
\hline Trditev & U N & VS \\
\hline Obveznosti so bile jasno predstavljene. & 3,7 & 3,8 \\
Izvedba predmeta je bila boljša, kot ste pričakovali. & 3,7 & 3,5 \\
Študijske obveznosti so bile obsežne. & 3,2 & 3,4 \\
Študijske obveznosti so bile zahtevne. & 3,0 & 3,0 \\
Tedenska navodila so bila razumljiva. & 3,4 & 3,5 \\
Preverjanje znanja je bilo skladno z učnim načrtom. & 3,4 & 3,9 \\
Predmet je možno opraviti le s sprotnim delom. & 3,3 & 3,4 \\
Obveznosti ste opravili brez težav. & 3,3 & 3,4 \\
\hline
\end{tabular}

Preglednica 6.13 Uporaba IKT in zavedanje izzivov njene uporabe

\begin{tabular}{lrr}
\hline Trditev & U N & VS \\
\hline Izboljšali ste sposobnosti uporabe I K T na splošno & 3,7 & 3,5 \\
Povečali ste zavedanje o možnosti uporabe I K T pri vsakod. delu. & 3,7 & 3,6 \\
Povečali ste zavedanje o nevarnostih uporabe IK T & 3,5 & 3,7 \\
\hline
\end{tabular}

nica 6.13). Študentje U N programa so bolj izboljšali svoje sposobnosti uporabe IK T na splošno ( $\mathrm{MUN}=3,7, \mathrm{MVS}=3,5$ ) kot tudi zavedanje o možnostih uporabe I K T v vsakodnevnem življenju in delu ( $\mathrm{MUN}=3,7$, MVS $=3,6$ ). Porast I K T-spretnosti je skladen s tem, kar ugotavljamo že pri I K T praktikumu - študentje, ki prihajajo iz gimnazijskih programov (izjema je program ekonomske gimnazije), imajo ob vstopu na fakulteto slabše razvite sposobnosti uporabe I K T kot vrstniki iz strokovnih programov, predvsem ekonomske smeri. Se pa te spretnosti tekom študija razvijejo in ob zaključku študija razlik ni ali naj bi jih ne bilo več.

Študentje vs programa so bolj naklonjeni študiju online $(M=3,9)$ od študentov U N programa $(M=3,2)$. Študentje (obeh programov) so $s$ študijem na U P F M zadovoljni - na petstopenjski lestvici so svoje zadovoljstvo ocenili z oceno 4,4 .

Študentje se vsako leto pritožujejo nad skupinskim delom, pri katerem je ocena odvisna od sodelovanja skupine in aktivnosti posameznih članov. Zato aktivnosti načrtujemo tako, da ima delež skupinskih nalog, kljub potrebam po skupinskem delu in sodelovanju (pričakovane kompetence študijskega programa), v končni oceni predmeta manjši delež $(19 \%)$ in je končna ocena odvisna predvsem od dela posameznega študenta (modri odtenki na sliki 6.33).

Tudi pri Poslovni informatiki spremljamo obremenitev študentov sproti vsak teden in na koncu izvedbe predmeta. Na sliki 6.34 prikazu- 


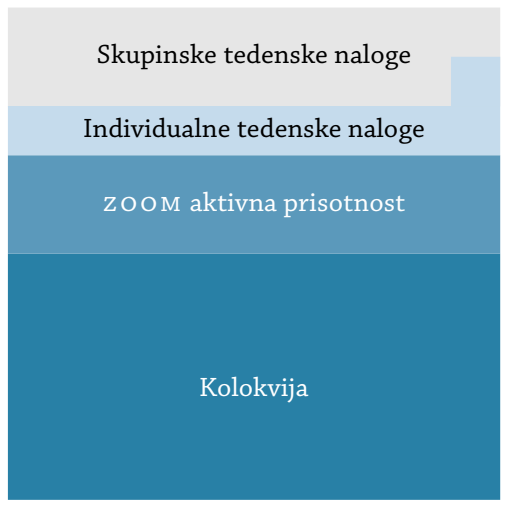

Struktura ocene predmeta

jemo podatke tedenskih mnenjskih anket. Študentje UN programa so v 4. tednu v povprečju poročali o več opravljenih urah, so pa zato v 5 . tednu poročali o manjšem številu ur. Gledano na celotno izvedbo predmeta med študenti UN in VS programa ni bilo značilnih razlik. Povprečen študent U N programa je $\mathrm{V}$ opravljanje študijskih obveznosti pri predmetu vložil 15,04 ure, študent vs programa pa 14,95 ure. V anketi o izvedbi predmeta so sicer poročali o nižjem povprečju ur (U N: 10,6 ur, Vs: 10,5 ure), je bilo pa tudi povprečno število ur, ki jih vložijo v opravljanje obveznosti na U P F M, nizko (U N: 17,1 ure, v s: 17,4 ure). Predmet Poslovna informatika se izvaja sedem tednov, kar pomeni, da je povprečen študent za opravljanje študijskih obveznosti porabil 105 ur. Glede na merila E C TS, ko bi povprečen študent za pridobitev šestih $\mathrm{KT}$ moral vložiti od 150 do 180 ur, bomo morali obremenitev študentov povečati, pa čeprav študentje menijo, da so bile študijske obveznosti obsežne (preglednica 6.12). Tedenska obremenitev študentov pri predmetu bi morala biti vsaj 20 ur tedensko, kar pa je celo več, kot študentje vlagajo v opravljanje vseh obveznosti na U P F M.

V anketi o izvedbi predmeta smo preverili še mnenja študentov o izvedbi e-izpitov. Postavili smo jim naslednje vprašanje:

Kaj menite o opravljanju preverjanja na daljavo prek exam.net? Ste imeli kakšne tehnične težave? Ali menite, da je takšen način opravljanje izpita primeren? Kje vidite morebitne izzive?

Komentarji so bili vsebinsko različni pa tudi različno obsežni. Zbrane komentarje smo kodirali v kategorije (preglednica 6.14). Kodiranje smo izvedli z orodjem za označevanje besedila (Highlight tool), ${ }^{23} \mathrm{v}$ izvoženi

${ }^{23}$ Glej https://workspace.google.com/u/o/marketplace/app/highlight_tool/65634221687. 
6 Evalvacija izvedb predmetov s področja poslovne informatike

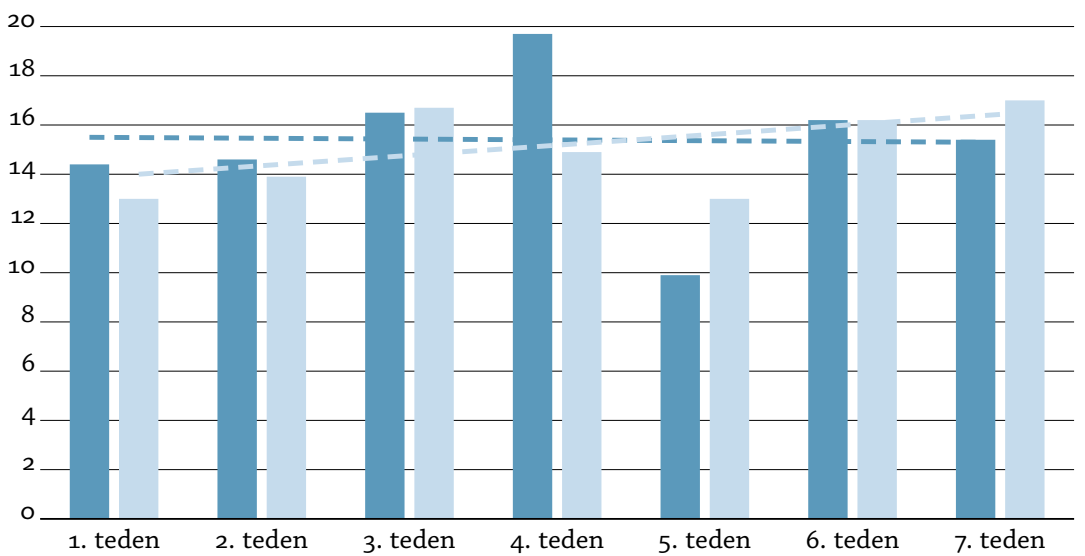

Slika 6.34 Primerjava tedenske obremenitve študentov (temno UN, svetlo vs)

Preglednica 6.14 E-izpiti-mnenja študentov

\begin{tabular}{lrr}
\hline Kategorija & $\mathrm{UN}(n=23)$ & $\mathrm{VS}(n=26)$ \\
\hline E-izpit je primeren & 21 & 25 \\
E-izpit ni primeren & 3 & 1 \\
Tehnične izzivi & 16 & 16 \\
Verodostojnost izpita & 2 & 6 \\
Drugo & 4 & 2 \\
\hline
\end{tabular}

preglednici pa prešteli komentarje posamezne kategorije (preglednica 6.14). Pri tehničnih težavah so zajete težave, s katerimi so se študentje srečali ali pa so jih le omenili kot izziv, na katerega je potrebno računati. Bistvenih razlik med skupinami študentov ni.

Glede primernosti izvedbe izpita so študentje izpostavili, da je takšen način preverjanja znanja celo boljši od ustnih izpitov, kakršne so imeli pri nekaterih drugih predmetih. Pri e-izpitu iz Poslovne informatike so izpit opravljali sočasno in pod istimi pogoji. Študentje so odgovarjali na ista vprašanja, in kot so napisali, je bil takšen izpit še "najboljši približek dejanskemu izpitu«. Eden je izpostavil tudi prednost dopolnjevanja in popravljanja že napisanih odgovorov, kar je pri klasičnih izpitih oteženo.

Kot negativen komentarj glede e-izpitov je en študent izpostavil bojazen, da takšen način izvedbe izpita predstavlja možnost vdora v zasebnost. Podrobnosti niso navedene, tako da ne vemo, kaj je imel v mislih. Ostala dva mnenja o neprimernosti izražata osebno nenaklonjenost takšnemu načinu izvedbe izpita. 
Od omenjenih 16 komentarjev o tehničnih izzivih je večina poročala, da težav ni imela, so pa izrazili bojazen, da bi izpad elektrike ali prekinitev internetne povezave povzročila stres. Obstaja tudi strah pred razveljavitvijo izpita. Pri izvedbi kolokvija smo se soočili s težavo, da se je neka študentka nahajala na območju, kjer so potekala dela na internetnem omrežju, in smo ji opravljanje izpita omogočili takoj, ko so bila dela zaključena. Naša odločitev je bila seveda pozitivno sprejeta.

Verodostojnosti izpita se je dotaknilo osem študentov, ki so izpostavili predvsem protokol, ki onemogoča oziroma minimizira možnost goljufanja na izpitu, kar je iz komentarjev možno razbrati kot pohvalo oziroma, kot se je izrazil eden od študentov, so bili vsi študentje "pravično ocenjeni«.

Pod »Drugo« so študentje izpostavili časovno omejitev (dva komentarja), težave s hrupom doma (en komentar), ostali komentarji pa so bili vezani na stres in strah pred tem, ali bo vse bo potekalo, kot je treba. Poglejmo še nekaj zanimivih obširnih komentarjev:

Na srečo večjih tehnični težav nisem imela. Zmotilo me je samo to, da smo bili časovno omejeni. Mislim, da bi potrebovali več časa. Za pisanje tovrstnega izpita je ta način primeren, mislim, da se bi se morali vsi izpiti pisati na tak način.

Zdi se mi, da je za profesorje ta način zelo primeren, saj res zmanjšuje možnost prepisovanja. Nam študentom pa predstavlja kar nekaj dodatnega stresa, saj se lahko vsakomur in kadarkoli zgodi, da ima slabšo povezavo ali pa se zgodi izpad elektrike in to povzroča še več strahu (če tehnologija ne deluje, izpita ne moramo opravljati). Jaz sem imela pri prvem kolokviju težavo, da se mi ni želel odpreti izpit, in potem nisem dobila povezave do posnetka zo o M-a. Vendar pa sem te težave hitro rešila.

Zdi se mi v redu, čeprav imam strah pred tem, saj me tehnologija pogosto pusti na cedilu ob najbolj pomembnih trenutkih, in pisanje izpita je zelo pomemben trenutek. Primerno se mi zdi, dokler se ne zgodi, da bi zaradi nedelovanja tehnologije morala pisati izpit še enkrat.

Reševanja izpitov na takšen način je zelo ustrezno in primerno, saj je tako bolj primerljivo pisanje izpitov, kjer študenti ne morejo goljufati in dosežejo realne ocene, kolikor so/niso študirali za predmet. Težavo sem imela samo zaradi tega, ker sem v brskalnik na- 
pačno pisala exam.net (zaradi nervoze). Ta način je zelo primeren in najbolj pošten, tako s strani študenta kot predavatelja. Izzivi se lahko pojavijo pri slabi internetni povezavi ali težkem dostopu do interneta.

Zaradi zagotavljanja varnosti se mi zdi primeren način, po drugi strani pa v primeru tehničnih težav izgubiš možnost opravljanja izpita, kar ni primerno. Tehnične težave niso vedno naša napaka. Sam exam.net se mi zdi v redu, cel izpitni protokol morda malo preveč zahteven. Nisem sicer imela do sedaj nobenih tehničnih težav, na srečo.

Izvedba izpita na takšen način je zelo primerna, ampak mislim, da mi je povzročila več stresa kot izpit :-) Morala sem biti pozorna, da opravim vse korake iz protokola po ustreznem redu, in sem imela občutek, da nekaj bom pozabila in da zaradi tega izpit ne bo veljaven. Kar se tiče samega programa, je zelo koristen in jasen, enostaven za uporabo, kar je seveda ena velika prednost.

V začetku se mi je zdelo, da je opravljanje izpita na takšen način bolj komplicirano, vendar je na koncu vse potekalo brez težav. $\mathrm{V}$ tem času menim, da je exam.net pravi način za opravljanje izpitov. Kar se tiče izzivov, lahko pride do tehničnih težav, vendar smo imeli takšne primere, ki jih je profesorica uspela rešiti.

\section{Doseganje učnih izidov}

Učni proces moramo načrtovati na način, da študentje dosežejo $z$ učnim načrtom načrtovane učne izide. Preverjanje doseganja učnih izidov je U P F M letos vključila tudi v študentske ankete, ki jih konec vsakega kvartala izvajamo na fakulteti. Po prvem kvartalu smo študente prek e-učilnice pozvali k izpolnitev ankete, vendar je bil odziv žal nizek - odzvalo se je le pet študentov, zaradi česar teh podatkov ne moremo predstaviti kot relevantnih. Ob zaključku tretjega kvartala pa smo študentom povezavo do ankete posredovali na začetku zo o M-ovega predavanja in počakali, da so izpolnili anketo. Tako jih je na anketo odgovorilo 21 (63,6\% vseh študentov pri predmetu). V anketo je U P F M vključila tudi vprašanja o napredovanju po posameznih učnih izidih, določenih $z$ učnim načrtom predmeta. Po prvem kvartalu so bili v anketo vključeni učni izidi, kot so zapisani v učnem načrtu (21 podrobno razčlenjenih učnih izidov), za anketo, ki jo študentje izpoljujejo po zaključenem tretjem kvartalu pa smo bili zaprošeni, da število izidov zmanjšamo na osem. 


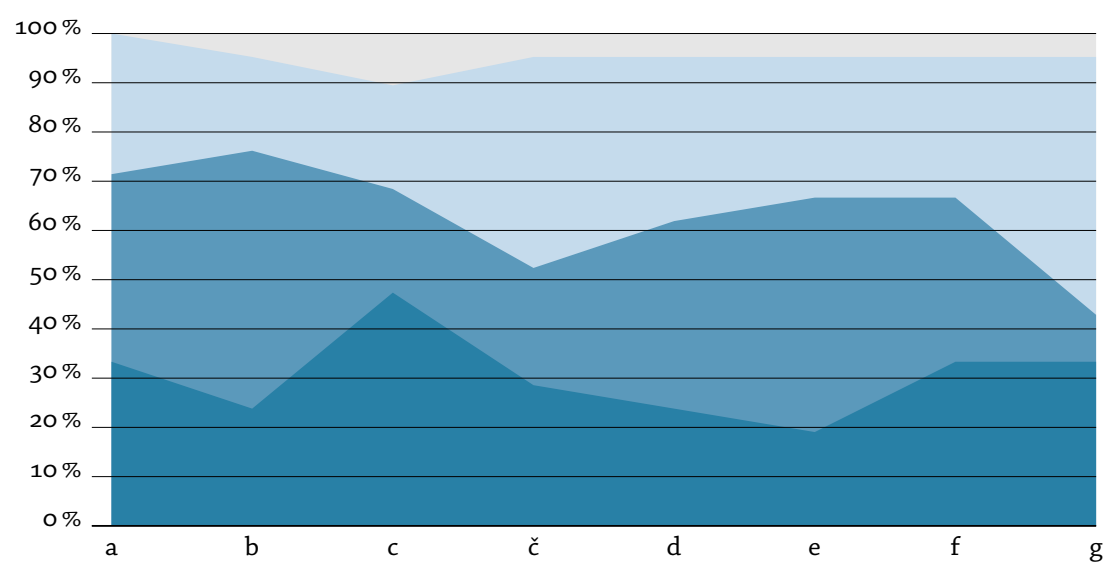

a Razumeti priložnosti, ki jih IT nudi za pridobivanje konkurenčne prednosti

b Razumeti vlogo in uporabnost is za uspešno delovanje poslovnih sistemov

c Razumeti delovanje računalniške strojne in programske opreme

č Razumeti osnovne koncepte in uporabnost računalniških omrežij

d Prepoznati prednosti in slabosti ter izzive e-poslovanja

e Razumeti vpliv razvoja I T na posameznika, podjetje in družbo

f Prepoznati nevarnosti, ki smo jim izpostavljeni pri uporabi interneta in svetovnega spleta

g Razviti spos. uporabe različnih I T-orodij za reševanje problemov in sodel. ter komunik.

Ocene: sivo - 2, svetlo modro - 3, srednje modro 4, temno modro - 5

Slika 6.35 Napredovanje študentov po izbranih učnih izidih $(n=21)$

Tako na sliki 6.35 prikazujemo napredovanje po učnih izidih študentov vs programa. Na vprašanje »Koliko ste, po vašem mnenju, napredovali na spodnjih področjih?« so študentje odgovarjali za osem učnih izidov, v katere smo združili prej omenjenih 21 izidov. Študentom je bila ponujena petstopenjska lestvica; ocena 5 je pomenila najvišjo vrednost, ocena 1 najnižjo. Kot je razvidno iz slike 6.35, ocene 1 ni izbral noben študent, pa tudi oceno 2 je izbral le eden oziroma dva pri razumevanju delovanja računalniške in strojne programske opreme. Študentje so se večinoma odločali za oceni 4 in 5 , izjema je področje računalniških omrežij in uporaba IT-orodij za reševanje problemov, sodelovanje ter komunikacijo. Glede na že prej ugotovljeno vrzel v UD š sta očitno to dve področji, ki ju moramo v naslednjem študijskem letu dopolniti in poglobiti.

Povprečne vrednosti napredovanja po učnih izidih prikazujemo $\mathrm{v}$ preglednici 6.15. Na ankete UN študentov smo prejeli le pet odgovorov, so pa bili ti odgovori v povprečju vsi nad 4,o, in to čeprav smo jim v presojo ponudili 21 učnih izidov.

Izpolnjevanje študentske ankete moramo $\mathrm{v}$ prihodnje vključiti $\mathrm{v}$ čas 
6 Evalvacija izvedb predmetov s področja poslovne informatike

Preglednica 6.15 Povprečne vrednosti napredovanja študentov

\begin{tabular}{lc}
\hline Trditev & VS \\
\hline Razumeti priložnosti, ki jih I T nudi za pridobivanje konkurenčne prednosti & 4,0 \\
Razumeti vlogo in uporabnost IS za uspešno delovanje poslovnih sistemov & 4,0 \\
Razumeti delovanje računalniške strojne in programske opreme & 4,1 \\
Razumeti osnovne koncepte in uporabnost računalniških omrežij & 3,8 \\
Prepoznati prednosti in slabosti ter izzive e-poslovanja & 3,8 \\
Razumeti vpliv razvoja IT na posameznika, podjetje in družbo & 3,8 \\
Prepoznati nevarnosti, ki smo jim izpostavljeni pri uporabi interneta & 4,0 \\
in svetovnega spleta & 3,7 \\
Razviti sposobnosti uporabe različnih IT-orodij za reševanje problemov & \\
in sodelovanje ter komunikacijo & \\
\hline OPOM BE $n=21$. &
\end{tabular}

organiziranih oblik dela s študenti, saj le tako zagotovimo večjo odzivnost. Na ankete, ki jih izvajalka izvaja pri predmetu, je odziv višji, saj so študentje za izpolnjeno anketo nagrajeni s točko, ki jo prištejemo k tedenskim nalogam. 


\section{Vrednotenje pedagoškega dela $\mathrm{v}$ visokem šolstvu}

\subsection{Uvod}

$\mathrm{V}$ raziskavi o razumevanju in odnosu do e-izobraževanja na UP smo preobremenjenost učiteljev zaznali kot oviro za nadaljnji razvoj eizobraževanja na U P. Intervjuvanci so izpostavili potrebo po drugačnem vrednotenju pedagoškega dela, kar bi učitelje spodbudilo k uvajanju sodobnih metod poučevanja, snovanju gradiv pa tudi k odpiranju izobraževanja. Zato želimo v nadaljevanju preučiti urejenost pedagoškega dela v zakonodaji in odpreti vprašanja, o katerih bi bilo vredno razmišljati v prihodnje. Ni naš namen razpravljati o različnih sistemih vrednotenja dela visokošolskega učitelja, saj bi to področje zaslužilo obravnavo v ločeni monografiji. Želimo le odpreti vprašanje načina vrednotenja dela učitelja v Sloveniji, ki, po naši oceni pa tudi oceni intervjuvancev o možnosti uporabe IKT na UP, predstavlja oviro za nadaljnje uvajanje IKT na UP. Oviro za uvajanje sodobnih pristopov predstavljajo tudi merila za izvolitve v nazive, kjer se za izvolitev v pedagoški naziv poudarjajo dosežki na raziskovalnem področju. Zato visokošolski učitelj, ki želi napredovati po akademski lestvici, svojo energijo prvenstveno usmerja $\mathrm{v}$ raziskovanje in objavljanje, manj pa v profesionalni razvoj na pedagoško-didaktičnem področju.

Zmotno je mišljenje laične javnosti, da delo visokošolskega učitelja obsega le pedagoško delo s študenti. Tega je v letnem obsegu delovnih ur le od 30 do $50 \%$, medtem ko je preostanek namenjen raziskovalnemu delu in sodelovanju pri upravljanju visokošolskih organizacij. Razmerja med različnimi področji se v posameznih državah razlikujejo. V Avstraliji imajo številne univerze vpeljan model $40: 40: 20^{1}$ (Miller 2019), čeprav se, kot ugotavlja Millerjeva, v praksi dogaja, da visokošolski učitelji $40 \%$ časa namenijo poučevanju in s poučevanjem povezanim aktivnostim, $25 \%$ časa raziskovanju, $35 \%$ pa administrativnim in drugim akademskim aktivnostim.

\footnotetext{
${ }^{1}$ Poučevanje $40 \%$, raziskovanje $40 \%$, sodelovanje pri upravljanju $20 \%$.
} 


\subsection{Pedagoško delo v normativnih aktih}

Pedagoško dejavnost poleg raziskovalnega in umetniškega dela skladno z 52. členom Zakona o visokem šolstvu (zVis) (2012) opravljajo visokošolski učitelji s habilitacijskimi nazivi docent, izredni in redni profesor ter lektor. Na visokošolskih strokovnih programih delo visokošolskega učitelja opravljajo tudi predavatelji in višji predavatelji. V izvedbo pedagoškega dela se vključujejo tudi visokošolski sodelavci, med katere $z V$ is (54. člen) uvršča asistente. Grobi okvir splošnih pogojev za izvolitev v posamezni naziv ureja $\mathrm{zVis}$, podrobna merila in postopke pa, skladno $\mathrm{z}$ zakonom, določa visokošolski zavod (55. in 57. člen $\mathrm{zV}$ is).

zVis (63. člen) opredeljuje obseg neposredne pedagoške obveznosti, ki se izvaja kot javna služba. Tako je njen obseg za docenta, izrednega in rednega profesorja od 5 do 7 ur tedensko, za višjega predavatelja, predavatelja in lektorja 9 ur tedensko, za asistenta pa 10 ur tedensko. Vsebino in obliko neposredne pedagoške obveznosti določa rektor univerze oziroma dekan samostojnega visokošolskega zavoda. Isti člen $\mathrm{zV}$ is določa pogoje in postopke zvišanja ali znižanja neposredne tedenske obveznosti.

Skladno z z Vis U P pedagoško delo ureja z internimi akti.

UP je leta 2004 sprejela »Akt o oblikah neposredne pedagoške obveznosti na U P« (v nadaljevanju Akt U P), ki 40-urno tedensko delovno obvezo pedagoških delavcev razvršča v:

- neposredno pedagoško obveznost, določeno s 63. členom zVis; oblike neposredne pedagoške obveznosti pa podrobno opredeljuje 2. člen akta;

- govorilne ure, priprave na pedagoški proces in s pedagoškim delom povezana administrativna dela;

- razvoj predmeta in pripravo študijskih gradiv;

- raziskovalno in umetniško dejavnost, ki ohranja habilitacijo za opravljanje pedagoške in raziskovalne dejavnosti;

- drugo strokovno in razvojno delo na U P ter članici;

- sodelovanje v komisijah in organih upravljanja na članici ter U P.

V neposredno pedagoško obveznost Akt U P vključuje (2. člen):

- izvajanje javnoveljavnega študijskega programa, kar vključuje izvajanje predavanj, seminarjev, vaj in laboratorijskih vaj, terensko delo, hospitacije in nastope, 
- sodobne oblike poučevanja, ki vključujejo problemsko učenje, edelo s študenti (usmerjanje, klepetalnice);

- mentorstvo pri zaključnih delih in praksi;

- preizkuse znanja (izpiti, kolokviji, domače in seminarske naloge, zagovori):

- individualno delo s študenti (konzultacije, tutorstvo, študijski obiski);

- umetniško delo s študenti.

Poleg v 63. členu zVis že opredeljenega obsega neposredne pedagoške obveznosti 3. člen Akta U P določa še obseg dela za učitelja veščin športne vzgoje 20 ur tedensko, učitelja veščin in strokovnega sodelavca 16 ur tedensko ter za laboranta in tehničnega sodelavca 21 ur tedensko.

UP je, poleg »Akta o oblikah neposredne pedagoške obveznosti na U P«, leta 2004 sprejela še »Merila za zmanjšanje neposredne pedagoške obveznosti«, ki določajo zmanjšanje obsega ur neposredne pedagoške obveznosti zaradi raziskovalnega dela na programih in projektih, pri svetovalnem ali razvojnem delu (4. člen meril). Obseg ur se lahko zmanjša za od ene do dveh tretjin neposredne pedagoške obveznosti.

Leta 2011 je UP sprejela "Pravilnik za vrednotenje dela pedagoških delavcev ter raziskovalcev U P«, leta 2017 pa še »Pravilnik o spremembah in dopolnitvah pravilnika za vrednotenje dela pedagoških delavcev ter raziskovalcev Univerze na Primorskem" (v nadaljevanju oboje kot Pravilnik za vrednotenje dela U P). Pravilnik za vrednotenje dela U P delovno obveznost pedagoškega delavca razdeli v tri kategorije (3. člen):

- neposredno pedagoško obveznost (N PO), ki predstavlja neposredno pedagoško delo (N P D) in posredno pedagoško delo (P P D) ter se opravlja v okviru rednega in izrednega študija;

- osnovno znanstveno-raziskovalno, umetniško in strokovno delo (RS/U D);

- sodelovanje pri upravljanju in razvoju članice in univerze (S U).

Neposredna pedagoška obveznost je vezana na izvedbo organiziranih oblik dela s študenti, akreditiranih s študijskim programom. 4. člen pravilnika sicer dopušča tudi druge oblike N P D, določene v aktu o oblikah neposredne pedagoške obveznosti. Če sedaj povežemo 4. člen Pravilnika za vrednotenje dela U P z 2. členom Akta UP, potem v N P D sodijo tudi sodobne oblike poučevanja, ki vključujejo problemsko učenje in edelo s študenti (usmerjanje, klepetalnice). To pomeni, da obstoječi pra- 
vilnik dopušča možnost vključevanja sodobnih oblik poučevanja, niso pa te vključene v nadaljnjo obravnavo Pravilnika za vrednotenje dela UP in zato v praksi tovrstno NPD ne zaživi. NPD se še vedno veže le na izvedbo tradicionalnih kontaktnih ur, kar deluje nestimulativno za uvajanje sodobnih metod dela pa tudi za pripravo študijskih gradiv za študente. Čeprav je "strokovna, pedagoška in metodična oziroma didaktična vrednost pedagoških pripomočkov, predvsem učbenikov«med elementi za presojo pedagoške usposobljenosti po Merilih za izvolitev v nazive U P (19. člen), pa 19. člen v nadaljevanju navaja, da se pri prvi izvolitvi visokošolskega učitelja pedagoška usposobljenost ugotavlja z dokazilom o opravljenem javnem preizkusnem predavanju, kasneje pa s pozitivno oceno pedagoške usposobljenosti, ki izhaja iz študentskih anket. Učitelji tako niso stimulirani za pripravo študijskih gradiv, so pa, glede na merila za izvolitev, spodbujeni v nabiranje točk iz raziskovalnega dela. Delež točk iz t.i. izobraževalnega dela je, v primerjavi s točkami iz raziskovalnega dela, precej nižji ${ }^{2}$ in hitro dosegljiv z nekaj mentorstvi. Če učitelj predava tujim študentom en semester, prejme štiri točke izobraževalne dejavnosti, kar predstavlja 53,3\% točk s področja izobraževalne dejavnosti v petletnem habilitacijskem obdobju. Izvedba takšnega dela je lahko povsem klasična.

UP ima vrednotenje dela učiteljev urejeno do podrobnosti. V Pravilniku za vrednotenje dela UP tako podrobno določa različne vrste posrednega pedagoškega dela in jih normira $z$ delovnimi urami. Tako npr. opredeljuje čas, porabljen za izvedbo pisnega ali ustnega izpita (o,5 ure na študenta), članstvo v komisiji komisijskega izpita ( 1 ura) in mentorstvo študenta pri zaključnih delih (15 ur na študenta na prvi bolonjski stopnji, 30 ur na drugi bolonjski stopni in 90 ur na doktorskem študiju) itn.

UP je leta 2011 izdala še »Navodila k Pravilniku za vrednotenje dela pedagoških delavcev in raziskovalcev U P«. Navodila v 3. točki določajo letno delovno obvezo pedagoškega delavca za polni delovni čas, ki skladno z delovno zakonodajo znaša 2.088 delovnih ur. Letni obseg delovnih ur vključuje tudi praznike, dopust, bolniško odsotnost in odmor za

${ }^{2}$ Izredni in redni profesor pri izvolitvi dokazujeta doseganje najmanj 7,5 točke iz izobraževalne dejavnosti v petletnem izvolitvenem obdobju, v primerjavi z najmanj 20 točkami raziskovalne dejavnosti za izrednega profesorja oziroma 30 točkami raziskovalne dejavnosti za rednega profesorja. Izvolitev v naziv docenta ne zahteva točk iz izobraževalne dejavnosti. 
malico. Skladno z navodili je delovna obveznost pedagoškega delavca sorazmerna $z$ deležem zaposlitve na visokošolskem zavodu. Če sedaj preračunamo 180 pedagoških ur iz 63. člena zVis, kolikor je na letni ravni predvideno za visokošolskega učitelja, v delovne ure (810), predstavlja to $38,8 \%$ delovne ur3 na letni osnovi. Kljub temu da iz letnega obsega nismo izključili ure praznikov in letnega dopusta, pa izračun izkazuje podobno nizek obseg pedagoškega dela, kot to velja za univerze v Avstraliji (Miller 2019).

Univerza v Ljubljani delo in pedagoške obveznosti visokošolskih učiteljev ter sodelavcev ureja s pravilnikom. ${ }^{3}$ Pravila se sklicujejo na akt o oblikah neposredne pedagoške obveznosti, ki ga na spletni strani ni mogoče najti. Smo pa na spletni strani univerze našli Merila za zmanjšanje neposredne pedagoške obveznosti, ki so po vsebini enaka merilom U P.

Na Univerzi v Mariboru (U M) imajo splošna merila za vrednotenje dela visokošolskih učiteljev in sodelavcev na ravni U M, potem še merila na ravni posamezne članice U M. Tako splošna merila opredeljujejo, da lahko članica U M v svojih merilih upošteva tudi zmanjšanje števila ur (do dveh) visokošolskih učiteljev zaradi števila študentov (6. člen meril). Takšne določbe na UP in UL ni.

\subsection{Predlog vrednotenja dela pri delu na daljavo}

V uvodu poglavja smo izpostavili vrednotenje kot oviro za uvajanje eizobraževanja v pedagoško prakso. Pred epidemijo večina visokošolskih učiteljev, kot tudi vodstva fakultet in univerze, ni pomislila, da je izvedba na daljavo sploh mogoča. Seveda se pri tem ni razmišljajo, da izvedba po spletu, torej ob podpori IK T - podobno kot informatizacija poslovanja $\mathrm{v}$ podjetju zahteva prenovo poslovnih procesov -, zahteva tudi prenovo pedagoškega procesa. Primere drugačnega načina izvajanja smo predstavili skozi evalvacijo izvedbe predmetov s področja poslovne informatike. V nadaljevanju želimo predstaviti idejni predlog alternativnega pristopa $\mathrm{k}$ vrednotenju dela učitelja, ki podpira tudi razvojne cilje UP za obdobje 2021-2024, in sicer na študenta osredinjen način dela. ${ }^{4}$ Predlagane spremembe nimajo finančnega učinka, imajo pa učinek na kakovost pedagoškega procesa. Poleg tega predlog prenaša odgovornost na visokošolskega učitelja, ki ohrani akademsko avtono-

\footnotetext{
${ }^{3}$ Glej https://www.uni-lj.si/mma/pravilnik/2018010814480824/.

${ }^{4}$ Razvojni cilj pokriva področje pedagoške odličnosti (točka 5) "Srednjeročne razvojne strategije U P 2021-2027《 (2020).
} 
Preglednica 7.1 Osnovni podatki predmetov

\begin{tabular}{lrrrll}
\hline Predmet & (1) & (2) & (3) & (4) & \\
\hline UN Poslovna informatika (2019) & 6 & 35 & 35 & 32 (27 izpit) \\
UN Študijski in I K T praktikum (2019) & 3 & 14 & 26 & 31 (24 izpit) \\
Vs Poslovna informatika (2019) & 6 & 35 & 35 & 33 (27 izpit) \\
\hline Skupaj & 15 & 84 & 96 & 96 & \\
\hline
\end{tabular}

OР ОМ В naslovi stolpcev: (1) kreditne točke, (2) število ur predavanj, (3) število ur vaj, (4) število študentov.

Preglednica 7.2 Preračun pedagoških ur v delovne ure

\begin{tabular}{lrrr}
\hline Neposredno pedagoško delo (N P D) & Normativ & Število & Del. ure \\
\hline P in S (docent, izredni ali redni profesor) & 4,5 & 84 & 378,0 \\
V (docent, izredni ali redni profesor) & 2,8 & 96 & 268,8 \\
\hline Skupaj N P D & & & 646,8 \\
\hline
\end{tabular}

mijo, uvaja pa tudi na študenta osredinjen način dela, hkrati pa tudi študent sprejema odgovornosti in obveznosti, ki se pričakujejo od bodočega diplomanta in ustvarjalca družbe znanja.

Predlog predstavljamo na primeru izvedb Poslovne informatike in I K T praktikuma, predstavljenih v poglavju o evalvacijah. Rezultati evalvacije so pokazali, da smo $\mathrm{z}$ načinom izvedbe predmeta izboljšali prehodnost študentov in pri tem dosegli vse $z$ učnim načrtom načrtovane učne izide.

Za simulacijo izračuna delovne obveze smo vzeli primer izredne profesorice, ki je predmete izvedla v celoti. V prikaz smo zajeli le predmete, predstavljene $\mathrm{v}$ evalvaciji izvedb predmetov, prilagojenih epidemiološki situaciji v državi (preglednica 7.1).

Izredna profesorica je pri predstavljenih predmetih izvedla 84 ur predavanj in 96 ur vaj, kar preračunano po navodilih v Pravilniku za vrednotenje dela UP predstavlja 132 ur NPD (84 ur predavanj in 96 ur $\times$ faktor o, $5=48$ ur) oziroma 73,33\% N P D, določene po 63. členu z Vis. Če je učitelj z izvedbo $15 \mathrm{KT}$ dosegel $73,3 \% \mathrm{~N}$ P D po ZVis, potem bi ob istih normativih za $100 \%$ N P D moral izvesti predmete v skupnem obsegu 20 KT.

Poglejmo na učiteljevo obremenitev še z drugega vidika. Upoštevajoč normative pravilnika pedagoške ure preračunajmo $\mathrm{v}$ delovne (preglednica 7.2).

Pravilnik o vrednotenju pedagoškega dela U P v 8. členu določa, da mora visokošolski učitelj poleg N P D opraviti še: 
Preglednica 7.3 Simulacija pedagoške obremenitve šest K T predmetov

\begin{tabular}{lrrrrr}
\hline Postavka & Normativ & Predmet 1 & Delovne ure & Predmet 2 & Delovne ure \\
\hline Predavanja & 4,5 & 30 & 135,0 & 45 & 202,5 \\
Vaje & 2,8 & 30 & 84,0 & 45 & 126,0 \\
Skupaj & & 60 & 219,0 & 90 & 328,5 \\
\hline NPD & $810-1008$ & & & & \\
N P D* & 876 & $25,0 \%$ & $37,5 \%$ \\
\hline
\end{tabular}

ОРОМве ${ }^{*}$ Ure predavanj = ure vaj.

- do $40 \%$ delovnega časa (400 do 800 delovnih ur) posrednega pedagoškega dela (P P D),

- do $30 \%$ delovnega časa (od 200 do 600 delovnih ur) osnovnega raziskovalnega, strokovnega in umetniškega dela (RS/U D),

- do $10 \%$ delovnega časa (do 200 delovnih ur) sodelovanja pri upravljanju (su).

Glede na to, da je N P D po 63. členu ZVis za izrednega profesorja 180 ur predavanj, bi ob upoštevanju normativov U P to pomenilo 810 delovnih ur. Če bi visokošolski učitelj izvedel le vaje, bi, skladno z navodili v Pravilniku za vrednotenje dela U P in s faktorjem o,5, moral opraviti 360 pedagoških ur, kar pa je 1.008 delovnih ur. V primeru s preglednico 7.2, upoštevajoč razmerje med predavanji in vajami, učitelj dosega $71,4 \%$ N P D.

Kot vidimo, se izračuni vrtijo okoli pedagoških ur, določenih z akreditiranim študijskim programom za posamezni predmet. Teh ur je za posamezni predmet lahko več (običajno so to obvezni predmeti dodiplomskega študija) ali manj (izbirni predmeti dodiplomskega ali predmeti podiplomskega študija).

ZVis v 37. členu določa, da dodiplomski študijski programi obsegajo najmanj 20 in največ 30 ur organiziranih oblik dela (predavanja, seminarji in vaje) tedensko, študijsko leto pa traja 30 tednov. Na letni ravni bi to pomenilo od 600 do 900 ur organiziranih oblik dela oziroma, upoštevajoč $60 \mathrm{KT}$ na leto študija (36. člen $\mathrm{zVis}$ ), od 10 do 15 ur na eno K T. Predpostavljajmo, da predmet v celoti izvaja visokošolski učitelj in da smo kontaktne ure razporedili na predavanja ter vaje (50:50\%) normativ delovnih ur bi potem bil 876 delovnih ur.

Če bi kot osnovo za izračun obremenitve učitelja sedaj vzeli KT, bi visokošolski učitelj, ki predmet izvaja sam $\mathrm{v}$ celoti, morali opravit štiri 6 K T vredne predmete, kot je Predmet 1, kar bi pomenilo 24 K T, oziroma 
2,7 predmeta, kot je Predmet 2, oziroma 16 K T. V praksi se je izkazalo, da je predmet, ki ga izvaja en izvajalec, bolje izveden, saj ima izvajalec boljši pregled nad vsemi študenti, jih spremlja in motivira za pravočasno opravljanje študijskih obveznosti, predvsem pa pravočasno zazna morebitne težave in ustrezno ukrepa. Ob večjem številu študentov (nad 40) pa en izvajalec že potrebuje pomoč. 


\section{Sklepna razmišljanja}

Monografija je nastajala sredi tretjega vala epidemije covida-19, po napornem letu dni dela na daljavo. Avtorica monografije uporabo I K T v pedagoškem procesu preučuje in jo tudi sama intenzivno vključuje $\mathrm{v}$ svoje delo že več kot 20 let, vendar si, tako kot številni njeni kolegi, ni predstavljala, da bo očem nevidna nevarnost naredila večji premik v smeri digitalnega preoblikovanja družbe kot vse pobude in projekti do sedaj. Če je pred epidemijo za delo na daljavo obstajala vrsta ovir, so zaposleni delo čez noč, s pomočjo tehnologije, začeli opravljati od doma, na daljavo. Na daljavo se je začelo izvajati tudi izobraževanje, pa čeprav pred epidemijo številne tradicionalne institucije o tem sploh niso razmišljale oziroma so izgovore iskale na različnih področjih - od neprimernosti študijskih vsebin, nepripravljenosti učiteljev za poučevanje na daljavo, manjkajoče opreme, neznanja do zakonskih ovir ipd., kar je pokazala tudi raziskava, opravljena na U P pred epidemijo (poglavje 3.3). Zadržanost slovenskih javnih visokošolskih zavodov do sprememb pri načinu izvedbe študijskih programov se kaže tudi iz razpisa za vpis $\mathrm{v}$ dodiplomske študijske programe. Analiza razpisa za vpis po prvem valu epidemije (študijsko leto 2021/2022) se ne razlikuje od analize, ki smo jo opravili pred sedmimi leti, pa čeprav bi po izkušnji z epidemijo to lahko pričakovali.

Del zadržanosti glede uvajanja I K T v pedagoški proces nedvomno izhaja tudi iz nesporazumov pri razumevanju terminologije. Zato smo razjasnitvi pojmov in povezanosti med posameznimi pojmi namenili ustrezno mesto. Tehnologija sama po sebi ne prinaša inovacij in višje kakovosti v izobraževalne organizacije, temveč je le orodje, ki olajša iz-

vedbo procesov (Fee 2009; Peterson idr. 2018). Številne učitelje skrbi, da bi zaradi nje izgubili delo, zaradi česar se oklepajo preizkušenih tradicionalnih načinov izvedbe, vezanih predvsem na izvedbo kontaktnih ur. Slednje so v visokem šolstvu še vedno osnova vrednotenja dela pedagoškega osebja, in to kljub sodobnim trendom na področju izobraževanja, ki v ospredje postavljajo študenta in delo, ki ga mora študent vložiti v 
opravljanje študijskih obveznosti. Vrednotenje dela učiteljev se je, v še pred epidemijo izvedeni raziskavi med prodekani za področje študijske (izobraževalne) dejavnosti in predstavniki članic U P za področje kakovosti, pokazalo kot resna ovira za intenzivnejše uvajanje IK T v pedagoški proces. Zato smo v monografiji prikazali simulacijo ideje o spremembi načina vrednotenja dela učiteljev s števila kontaktnih ur na kreditne točke, ki jih učitelj pridobi. Postindustrijsko izobraževanje zahteva drugačen pristop $\mathrm{k}$ poučevanju in učenju pa tudi drugačen pristop $\mathrm{k}$ organiziranosti in izvajanju izobraževalne dejavnosti. Družba znanja zahteva drugačna znanja in veščine, ne samo študentov, tudi učiteljev. Razvoj tehnologije še dolgo ne bo nadomestil učiteljev, saj tehnologija in tehnološke rešitve same po sebi niso dovolj. $\mathrm{Na}$ to opozarjajo številne raziskave, prikazane v monografiji. Celo revolucija izobraževanja, ki je povezana z množičnimi odprtimi spletnimi tečaji (M o o cs), kljub tehnološko izpopolnjenim tečajem ni dosegla pričakovanih rezultatov, sploh pa ne ogroža visokega šolstva, kot je mnoge skrbelo (Reich in Ruipérez-Valiente 2019). Učeči se v procesu učenja bolj kot posredovanje znanja potrebujejo osmišljen, voden in s strani učitelja koordiniran proces učenja, ki učečega se usmerja $k$ doseganju učnih izidov. Znanje v družbi znanja gradi učeči se, kar je skladno s konstruktivistično teorijo učenja (Bates 2005, 7). Razvoj tehnologije prostor učenja z učilnic in izobraževalnih organizacij širi na globalno raven, zato danes govorimo tudi o konektivistični teoriji učenja ter teoriji skupnosti raziskovanja (Bregar, Zagmajster in Radovan 2020). ${ }^{1}$

Premik v smeri digitalizacije izobraževanja v Sloveniji ni uspel tudi številnim projektom na področju I K T v izobraževanju (od projektov RO dalje). ${ }^{2}$ Tehnologija je spomladi 2020 postala vseprisotna po celotni izobraževalni vertikali, ne glede na raven izobraževanja in učne vsebine. Res pa je, da je bil to le začasen in nujen odziv na izredne razmere, ne pa načrtovan in osmišljen prenos izobraževanja na daljavo. Takšen odziv in prilagoditev na epidemijo sta sprožila vrsto polemik o negativnih učinkih, ki jih v monografijo nismo želeli vključiti. Pa ne zato, ker bi si negativni učinki nenačrtovanega in ad hoc prehoda na daljavo ne zaslužili obravnave - v monografiji smo se omejili le na reševanje izzivov, s katerimi se je srečalo visoko šolstvo, predvsem pa smo, skozi študijo

\footnotetext{
${ }^{1}$ Več o teorijah učenja v Bregar idr. (2020, 84-95).

${ }^{2}$ Več o dosedanjih slovenskih projektih na področju I K T v izobraževanju v Bregar idr. (2020, 29-33).
} 
primera na UP F M, želeli predstaviti, da so učinki spopada s koronaizzivom lahko tudi pozitivni. Zgodovina je pokazala, da se poučevanje na daljavo ni zgodilo prvič (Johnson, Veletsianos in Seaman 2020), je pa prehod v to obliko dela tokrat prvič imel globalne razsežnosti. In ker se zgodovina ponavlja, smo želeli odzive zbrati, jih analizirati in ovrednotiti, predvsem pa ohraniti, saj bi bilo to vedenje koristno vključiti $\mathrm{v}$ dokumente, ki obravnavajo ravnanje in odzive na krizne situacije $\mathrm{v}$ izobraževalnih organizacijah. Za izobraževalne organizacije je uspešna prilagoditev izvajanja pedagoškega procesa v krizi ključna, zato je scenarije prilagajanja kriznim situacijam (in okrevanja po krizi) potrebno vključiti v ustrezne strateške dokumente ter dokumente na področju varnostne politike. Izvajanje izobraževalne dejavnosti potrebuje managerske prijeme - od načrtovanja, zagotavljanja virov, organiziranja in spremljanja do vrednotenja procesov in rezultatov ter, nenazadnje, tudi sistema stalnih izboljšav.

Vloga managementa se kaže tudi pri informatizaciji procesov. Informatizacija poslovanja v podjetjih zahteva odločno podporo vodstva, sicer so projekti informatizacije že $\mathrm{v}$ začetku obsojeni na propad (Laudon in Laudon 2018). Enako velja za izobraževalne organizacije - brez podpore in aktivne vključenosti njihovih vodstev so projekti informatizacije neuspešni. Praksa na U P je - s tremi neuspešnimi poskusi projektov za razvoj strategije uvedbe študija na daljavo na univerzi - to samo še podkrepila. Potreba po vključenosti vodstva v procese informatizacije je vidna tudi iz raziskave o razumevanju e-izobraževanja na U P, ki smo jo predstavili v poglavju 3.3.

V monografiji smo se omejili le na UP in UP FM, ki ima pri uporabi I K T v pedagoškem procesu največ izkušenj. Prednost slednjih se je pokazala pri odzivu na zaprtje univerze, saj so učitelji te fakultete pedagoško dejavnost iz klasičnega v izvajanje na daljavo spremenili praktično čez noč. Uspešnega odziva na zaprtje univerze bi ne bilo, če učitelji UP F M ne bi imeli izkušenj s t.i. e D Oš, ki so jih bili zaradi finančnih težav primorani uvesti $v$ študijskem letu 2017/2018. Seveda je $k$ pozitivnemu odzivu pripomogla podpora e-izobraževanja, ki je bila v času epidemije še dodatno intenzivirana. Odzivnost U P F M potrjuje, da je izvedba izobraževalne dejavnosti, kot osrednje dejavnosti izobraževalne organizacije, resen managerski in upravljavski izziv, h kateremu je potrebno pristopiti strokovno.

Poseben managerski izziv predstavlja izvedba izpitov na daljavo. $\mathrm{Na}$ U P F M smo se, kot prva članica U P, z njim spoprijeli in ga uspešno rešili. 
Razvili smo kar nekaj protokolov in jih prosto delili tudi s širšo izobraževalno skupnostjo v Sloveniji. Da bi protokoli ne šli v pozabo in da nas ponovitev situacije ne bi presenetila, smo nekatere od njih predstavili $\mathrm{v}$ monografiji.

Pozitivne izkušnje izvajanja pedagoškega procesa bo marsikateri učitelj uporabil tudi v prihodnje. E-izvedba študijskih programov je odprla prostor za inovacije in vključevanje sodobnih metod poučevanja, hkrati pa predstavlja tudi vzvod za vključevanje sodobnih trendov, predvsem na študenta usmerjenega izobraževanja. Razvoj tehnologije in poslovni modeli razvoja aplikacij uresničujejo ekonomijo pozornosti, ki deležnike izobraževalnega procesa pogosto zaslepi in oddalji od bistva študijskega procesa. Le-to je še vedno $v$ poglobljeni dejavnosti posameznika (študenta), ki v interakciji z gradivi in drugimi učečimi se gradi svoje znanje. Študij je resno in trdo delo, ne pa zabava, kar sicer ne pomeni, da se študentje pri študiju ne smejo imeti lepo in zabavno, zavedati pa se morajo, da se od študentov rednega študija pričakuje od 1.500 do 1.800 ur dela na leto. Tega se moramo zavedati tudi visokošolski učitelji, ko načrtujemo izvedbo predmeta. Vloga visokošolskega učitelja se mora spremeniti, saj v družbi znanja, ko so izobraževalni viri globalno dostopni, poučevanje ne sme in ne more potekati (in tudi biti vrednoteno) le prek kontaktnih ur.

Monografijo smo želeli dopolniti s prikazom izvedbe posameznih predmetov s področja poslovne informatike, katerih izvedba je bila $\mathrm{v}$ rokah avtorice. Izboljšave visokošolskega poučevanja lahko dosežemo le s podrobno evalvacijo izvedbe predmeta, ki presega standardizirane študentske ankete na visokošolskem zavodu. Rezultati evalvacij so pokazali, da je prilagoditev novim razmeram prinesla značilen kakovosten premik v izvedbi in predvsem večjo prehodnost študentov, kar je še posebej pomembno. Na to nedvomno vpliva dejstvo, da ima izvajalka predmetov dolgoletne izkušnje z uporabo I K T. Z usposabljanjem visokošolskih učiteljev za delo prek spletnih učnih okolij bi bili podobni rezultati vidni tudi pri drugih predmetih.

Želeli bi izpostaviti še en vidik. Obvladovanje skupine študentov je pri enem izvajalcu lažje, ustvari se bolj povezana skupnost, hitreje se zaznajo morebitne težave in posledično se jih tudi hitreje odpravi. Avtoričine izvedbe predmeta Poslovna informatika za izredne študente nismo posebej prikazovali, saj je pri njej sodelovalo le devet študentov. Naj pa omenimo, da je celotna skupina študentov po oddaji izpita na daljavo (izpit je potekal na način kot kolokviji pri istoimenskem predmetu na 
rednem študiju) ostala $\mathrm{v}$ videokonferenčni izpitni sobi in se $\mathrm{z}$ izvajalko predmeta zadržala v prijetnem "poslovilnem « klepetu. ${ }^{3}$ Takšni dogodki so nedvomno dokaz, da je oblikovanje učeče se skupnosti v spletnem učnem okolju izrednega pomena, in na tem je poučevanje po spletu tudi potrebno graditi. Načine vzpostavitve in vzdrževanja online skupnosti je že pred skoraj 20 leti predstavila Salmonova (2002).

Tradicionalno izobraževanje potrebuje prenovo, tako kot poslovni procesi v podjetju pred informatizacijo poslovanja zahtevajo prenovo poslovnih procesov. Odpiranje vprašanja o drugačnem vrednotenju učiteljevega dela odpira prostor za prenovo. Učiteljeva skrb se mora od evidentiranja izvedenih kontaktnih ur premakniti k stalnemu posodabljanju študijskih vsebin, razvoju drugačnih pristopov, s katerimi se odgovornost za učenje prenaša na učečega se. Le-ta pa v komunikaciji in interakciji z ostalimi učečimi se gradi svoje znanje in razvija sposobnosti učenja. Nesporno je, da se družba spreminja bolj kot kadar koli do sedaj, in kot takšna potrebuje večne iskalce znanja. Vseživljenjsko izobraževanje vse bolj postaja imperativ družbe znanja.

\footnotetext{
${ }^{3}$ Vseh devet študentov je izpit tudi opravilo.
} 



\section{Literatura}

Atkinson, A. 2020. "Zoom: A Brief History of the Company that Redefined Video Conferencing.«https://www.switch4teams.com/post/zoom-historyvideo-conferencing.

Bates, T. 2005. Technology, E-Learning and Distance Education. 2. izd. New York: Routledge.

Bregar, L., in M. Zagmajster. 2003. »Elektronsko izobraževanje v praksi: primer programa L O L A."Andragoška spoznanja 9 (1): 79-85.

Bregar, L., M. Zagmajster in M. Radovan. 2020. E-izobraževanje za digitalno družbo. Ljubljana: Andragoški center.

Brown, S. 2019. "Using Assessment and Feedback to Empower Students and Enhance Their Learning. "V Innovative Assessment in Higher Education, ur. C. Bryan in K. Clegg, 50-63. New York: Routledge.

Brown, E., in C. Glover. 2019. "Evaluating Written Feedback. V Innovative Assessment in Higher Education, ur. C. Bryan in K. Clegg, 77-87. New York: Routledge.

Daniel, J. 1996. Mega-Universities and Knowledge Media: Technology Strategies for Higher Education. London: Routledge.

Doba. 2020. Doba: 1990-2020; 30 let poslovne skupina Doba. Ur. J. Dominko Baloh. Maribor: Doba.

Fee, K. 2009. Delivering E-Learning: A Complete Strategy for Design Application and Assessment. London in Philadelphia, PA: Kogan Page.

Ferlič Žgajnar, B. 2020. »Zaradi gripe s pridruženimi obolenji šest smrti.«Delo, 30. januar. https://old.delo.si/novice/slovenija/zaradi-gripe-s -pridruzenimi-obolenji-sest-smrti-273364.html.

Florjančič, V. 2014. »E-študij v slovenskem visokošolskem prostoru. « Didactica Slovenica-Pedagoška obzorja 29 (3-4): 139-155.

_ . 2018. »Business Students' Experience with Peer Grading.« V Learning Technology for Education Challenges, ur. L. Uden, D. Liberona in J. Ristvej, 93-104. Communications in Computer and Information Science. Cham: Springer International.

Florjančič, V., in L. Wiechetek. V tisku. »Using Moodle and Ms Teams in Higher Education a Comparative Study."International Journal of Innovation and Learning. 
Florjančič, V., J. Vičič, S. Pelc, I. Makarova Tominec, I. Rižnar, I. Stubelj, M. Malej, Š. Godnič Vičič, S. Planinc, B. Žvanut in P. Pucer. 2019. »Vsebinsko poročilo o doseganju kazalnikov pri izvajanju projekta InoTeZ - Inovativno s tehnologijo do znanja.« Ur. V. Florjančič. Univerza na Primorskem, Koper.

Hodges, C., S. Moore, B. Lockee, T. Trust in A. Bond. 2020. »The Difference Between Emergency Remote Teaching and Online Learning.« Educause Review. https://er.educause.edu/articles/2020/3/the-difference-betweenemergency-remote-teaching-and-online-learning.

Jackel, B., J. Pearce, A. Radloff in D. Edwards. 2017. Assessment and Feedback in Higher Education: A Review of Literature for the Higher Education Academy. Heslington: Higher Education Academy.

Jarvis, P., J. Holford in C. Griffin. 2003. The Theory and Practice of Learning. 2. izd. New York: Routledge.

Johnson, N., G. Veletsianos in J. Seaman. 2020. »U.S. Faculty and Administrators' Experiences and Approaches in the Early Weeks of the COVID-19 Pandemic«. Online Learning 24 (2): 6-21.

Kaufman, D. 1989. »Third Generation Course Design in Distance Education«V Post-Secondary Distance Education in Canada: Policies, Practices and Priorities, ur. R. Sweet, 61-78. Athabasca: Athabasca University.

Keegan, D. 199o. Foundations of Distance Education. London in New York: Routledge.

Keengwe, J., T. Kidd in L. Kyei-Blankson. 2009. „Faculty and Technology: Implications for Faculty Training and Technology Leadership." Journal of Science Education and Technology 18 (1): 23-28.

Laudon, K. C., in J. P. Laudon. 2018. Management Information Systems: Managing the Digital Firm. Harlow: Pearson Education.

Marentič-Požarnik, B. 200o. Psihologija učenja in pouka. Ljubljana: Dz S.

Marinoni, G., H. van't Land in T. Jensen. 2020. The Impact of Covid-19 on Higher Education around the World: IAU Global Survey Report. Pariz: International Association of Universities.

Merila za akreditacijo in zunanjo evalvacijo visokošolskih zavodov in študijskih programov. 2017. Uradni list Republike Slovenije, št. 42. https://www .uradni-list.si/1/objava.jsp?sop=2017-01-2150.

Miller, J. 2019. „Where Does the Time Go? An Academic Workload Case Study at an Australian University. " Journal of Higher Education Policy and Management 41 (6): 633-645.

Mueller, P. A., in D. M. Oppenheimer. 2014. "The Pen Is Mightier Than the Keyboard: Advantages of Longhand Over Laptop Note Taking."Psychological Science 25 (6): 1159-1168.

Nipper, S. 1989. »Third Generation Distance Learning and Computer Confe- 
rencing «V Mindweave: Communication, Computers and Distance Education, ur. R. Mason in A. Kaye, 63-73. Oxford: Pergamon.

O E C D. 2020. Remote Online Exams in Higher Education during the COVID-19 Crisis. OECD Education Policy Perspectives 6. Pariz: OECD Publishing.

Peters, O. 1983. »Distance Education and Industrial Production: A Comparative Interpretation in Outline. $\mathrm{V}$ Distance Education: International Perpectives, ur. D. Steward, D. Keegan in B. Holmberg, 95-113. London in New York: Croom Helm Routledge.

Peters, O. 1997. »Industrialised Teaching and Learning.« http://www.c3l.unioldenburg.de/cde/econ/readings/peters97.htm.

Peterson, A., H. Dumont, M. Lafuente in N. Law. 2018. „Understanding Innovative Pedagogies: Key Themes to Analyse New Approaches to Teaching and Learning." OE CD Education Working Papers 172, OE CD, Pariz. https://doi.org/10.1787/9f843a6e-en.

Reich, J., in J. A. Ruipérez-Valiente. 2019. "The Mooc Pivot." Science 363 (6423): 130-131.

Salmon, G. 2002. E-tivities: The Key to Active Online Learning. New York: Routledge.

Sangle, S. B., K. N. Nandurkar in P. J. Pawar. 2020. "Incorporating E-Assessment Tools in Teaching for Effective and Authentic Assessment. « Journal of Engineering Education Transformations 33: 130-136.

Sclater, N., A. Peasgood in J. Mullan. 2016. Learning Analytics in Higher Education: A Review of $U K$ and International Practice. Bristol: J IS C.

Simonson, M., S. E. Smaldino, M. Albright in S. Zvacek. 2011. Teaching and Learning at a Distance: Foundations of Distance Education. 5. izd. Boston, MA: Pearson.

S TA. 2020. "Na številnih šolah izbruhi viroz, tudi gripe.«Dnevnik, 23. januar. https://www.dnevnik.si/1042920381.

Stödberg, U. 2012. "A Research Review of e-Essessment. "Assessment \& Evaluation in Higher Education 37 (5): 591-604.

Sulčič, V. 2001. „Vpliv informacijske tehnologije na študij na daljavo v Sloveniji.« Magistrsko delo, Univerza v Mariboru.

— 2007. »Od ideje do izvedbe e-izobraževanju v terciarnem izobraževanju.«V Moodle.si: nacionalna konferenca, 82-91. Koper: Fakulteta za management; Ljubljana: Šola za ravnatelje.

- 2008. E-izobraževanje v visokem šolstvu. Koper: Univerza na Primorskem.

Šteh, B., in M. Šarić. 2016. "Ocenjevanje v visokem šolstvu: ovira ali spodbuda za kakovostni študij.«V Izboljšanje kakovosti poučevanja in učenja v visokošolskem izobraževanju: od teorije $k$ praksi, od prakse k teoriji, ur. K. Aškerc, S. Cvetek, V. Florjančič, M. Klemenčič, B. Marentič-Požarnik in S. Rutar, 
64-69. Ljubljana: Center Republike Slovenije za mobilnost in evropske programe izobraževanja in usposabljanja.

Tejedor, S., L. Cervi, A. Pérez-Escoda, F. Tusa in A. Parola. 2021. »Higher Education Response in the Time of Coronavirus: Perceptions of Teachers and Students, and Open Innovation. « Journal of Open Innovation: Technology, Market, and Complexity 7 (1): 43. https://doi.org/10.339o/joitmc7010043.

Trunk Širca, N., in V. Sulčič. 2010. "Odprti visokošolski prostor: vseživljenjsko učenje in I K T v izobraževanju."V Model učinkovitega managementa visokošolskega zavoda, ur. Nada Trunk Širca, 249-257. Koper: Fakulteta za management.

UNES C O, UNICEF in World Bank. 2020. What Have We Learnt? Overview of Findings from a Survey of Ministries of Education on National Responses to COVID-19. Pariz: UN E S CO; New York: UNICE F; Washington, D C: World Bank.

Univerza v Ljubljani. 2020. "Poučevanje in študij na daljavo v času covid-19.» https://www.zf.uni-lj.si/images/kakovost/UL_ZF_Poro\%C4\%8Dilo _pou\%C4\%8Devanje_in_\%C5\%A1tudij_na_daljavo_v_\%C4\%8Dasu _COVID-19_2.9.2020.pdf.

Univerza na Primorskem. 2004a. »Akt o oblikah neposredne pedagoške obveznosti na UP.« https://www.upr.si/sl/resources/files//univerza/interniakti/20062501aktneposrpedobv.pdf.

. 2004b. "Merila za zmanjšanje neposredne pedagoške obveznosti.« https://www.upr.si/sl/resources/files//univerza/interni-akti/merila-zazmanjsanje-neposredne-pedagoske-obveznosti.pdf.

- 2011a. »Navodila k Pravilniku za vrednotenje dela pedagoških delavcev in raziskovalcev U P.«https://www.upr.si/sl/resources/files//univerza /interni-akti/navodilapravilnikvrednotenjepedag.delaokt2011.pdf. . 2011b. »Pravilnik za vrednotenje dela pedagoških delavcev ter raziskovalcev U P.« https://www.upr.si/sl/resources/files//univerza/interni -akti/pravilnikvrednotenjepedagoskegadelajunij2011.pdf.

. 2017. "Pravilnik o spremembah in dopolnitvah pravilnika za vrednotenje dela pedagoških delavcev ter raziskovalcev Univerze na Primorskem." https://www.upr.si/sl/resources/files//univerza/interni-akti/sprem -pravilnik-vrednotenjedela2017-12-07-2017.pdf.

—. 2020. "Srednjeročna razvojna strategija U P 2021-2027.« https://www .upr.si/si/univerza/predstavitev/srednjerocna-razvojna-strategija-up -2021-2027/.

Wagenseil, P. 2021. "Zoom Security Issues: Here's Everything That's Gone Wrong (so Far). «Tom's Guide, 10. maj. https://www.tomsguide.com/news /zoom-security-privacy-woes. 
Warburton, B. 2009. "Quick Win or Slow Burn: Modelling U K H E C A A uptake.« Assessment \& Evaluation in Higher Education 34 (3): 257-272.

Wiliam, D. 2011. »What Is Assessment for Learning?« Studies in Educational Evaluation 37 (1): 3-14.

Zagmajster, M. 2006. Pregled študija na daljavo na področju izobraževanja odraslih v Sloveniji. Ljubljana: Andragoški center Slovenije.

Zakon o visokem šolstvu (z Vi S-U P B 7). 2012. Uradni list Republike Slovenije, št. 32. https://www.uradni-list.si/1/objava.jsp?sop=2012-01-1406. 



\section{Priloge}

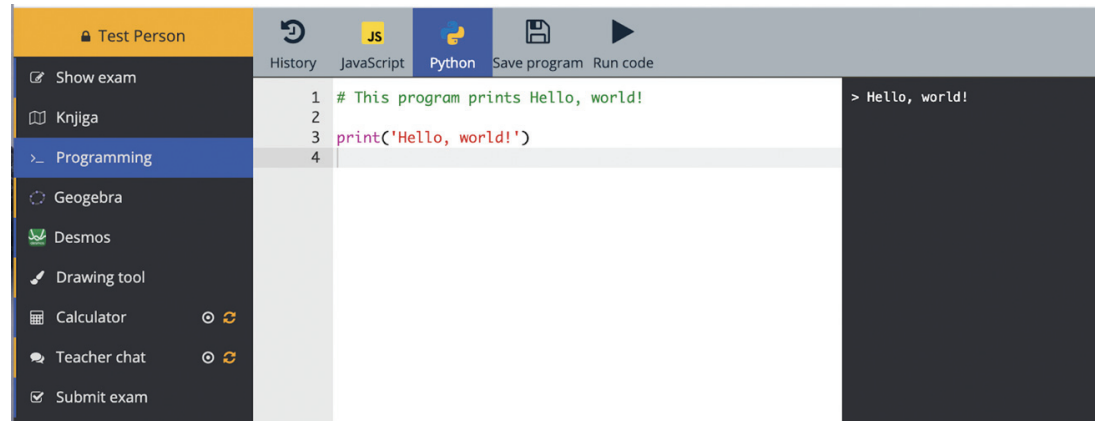

Priloga 1 Exam.net-programiranje (Python)

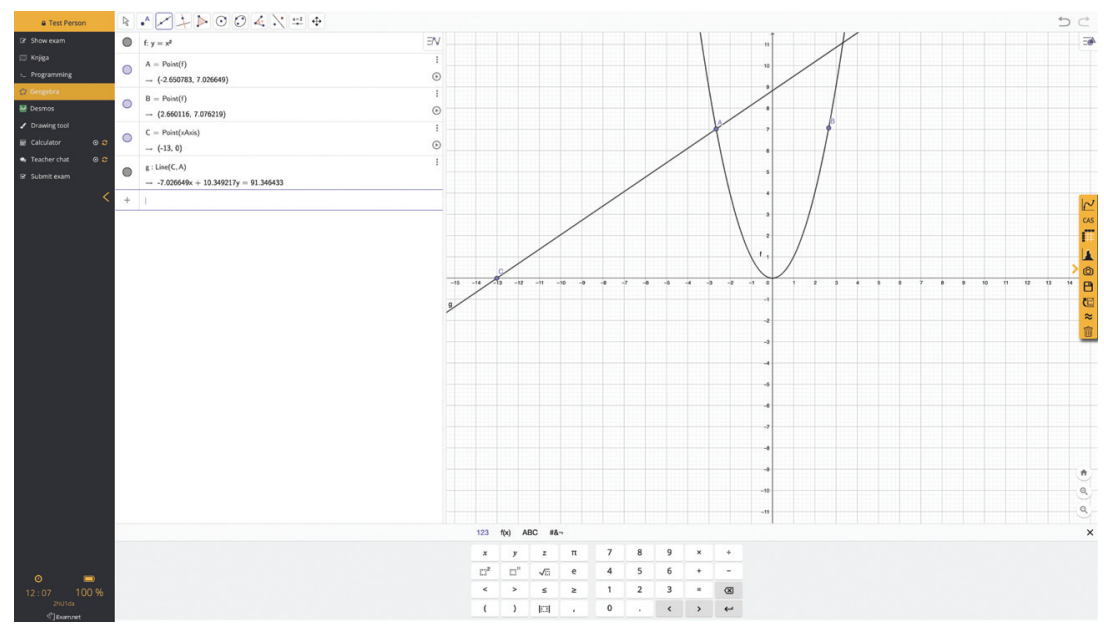

Priloga 2 Exam.net-Geogebra Classic (pogled CAS) 
Priloge

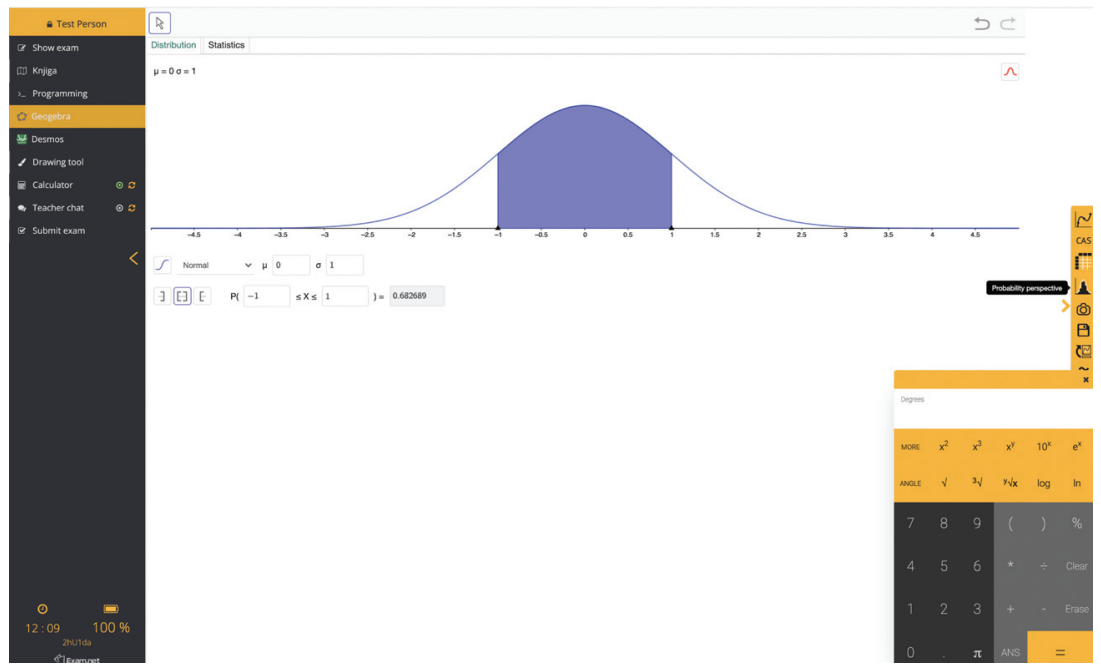

Priloga 3 Exam.net-Geogebra Classic (pogled verjetnosti)

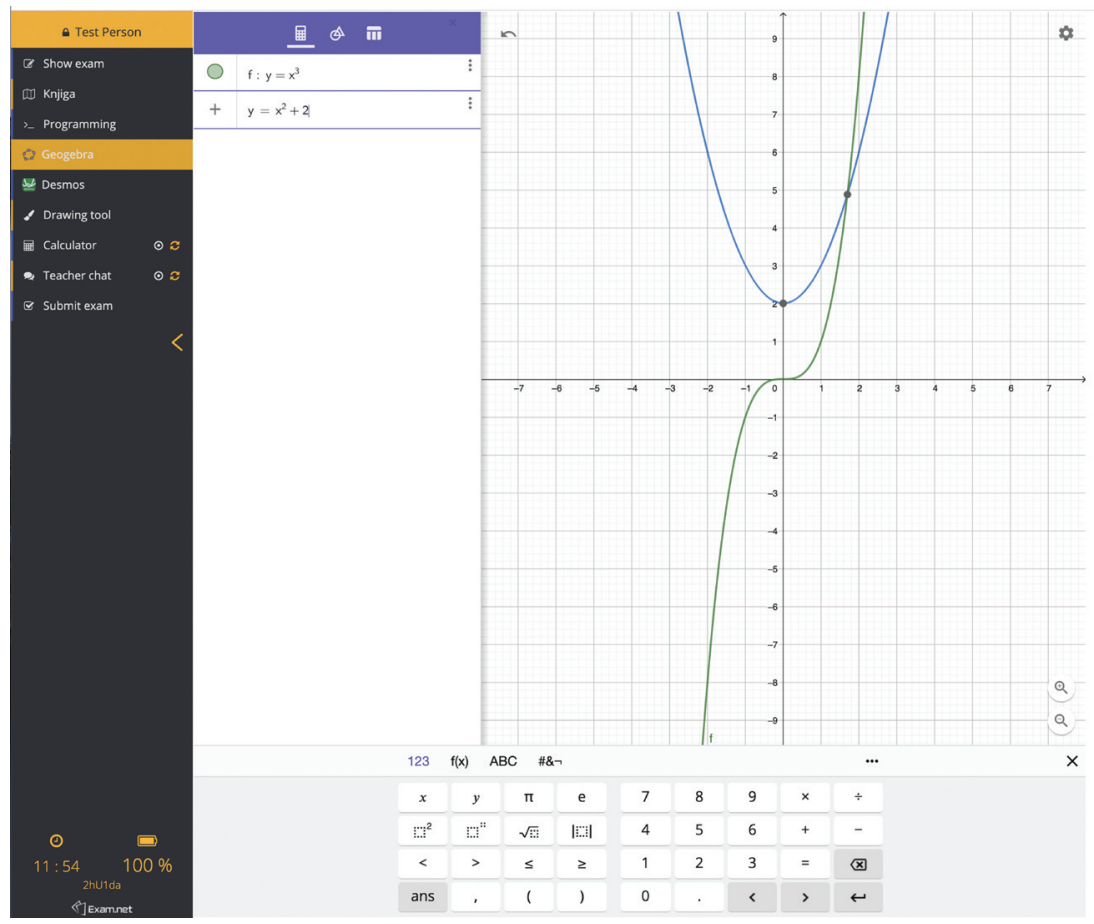

Priloga 4 Exam.net-Geogebra Graphic 
Priloge

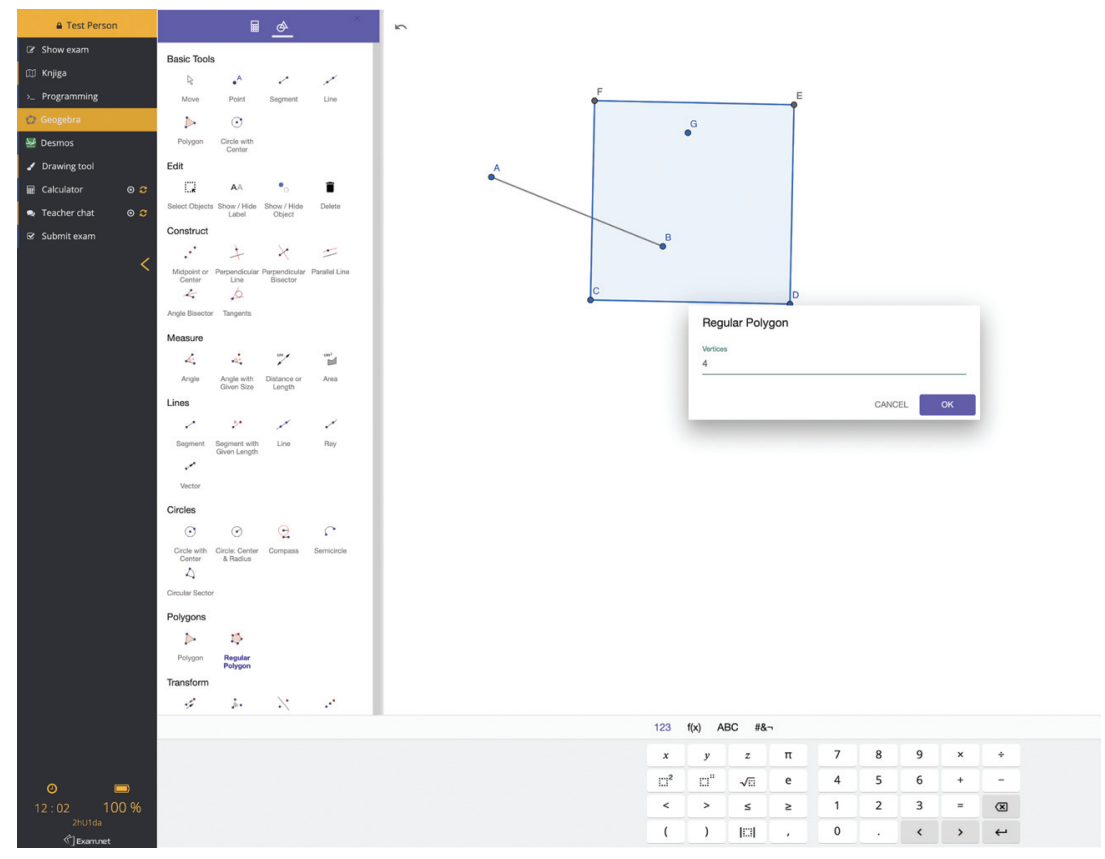

Priloga 5 Exam.net-Geogebra Geometry

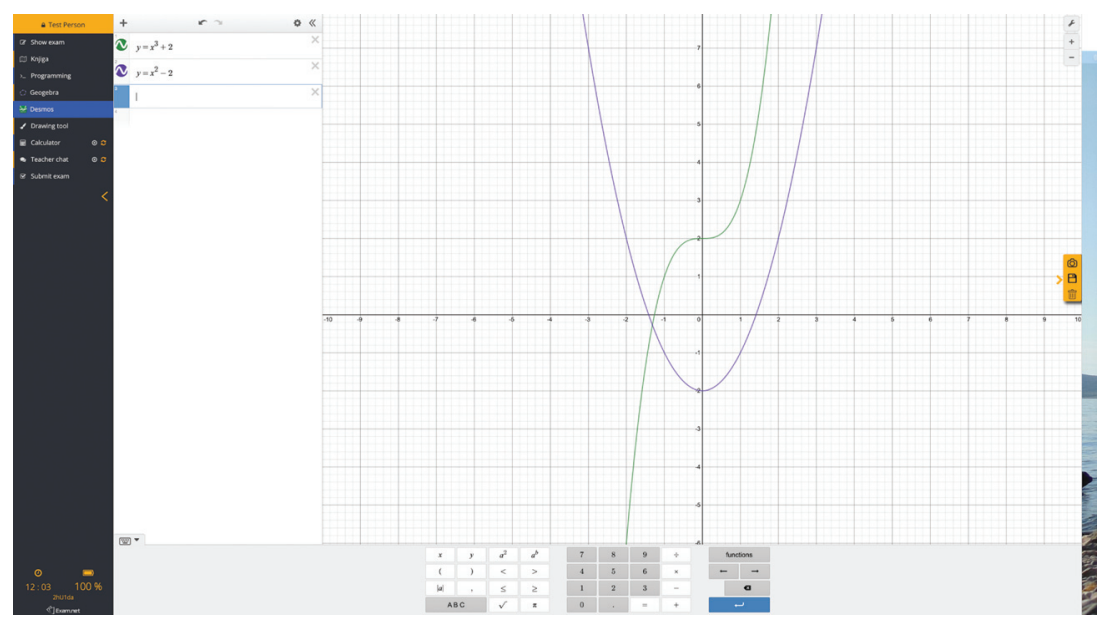

Priloga 6 Exam.net-Desmos 


\section{Priloge}

Priloga 7

Exam.net - risanje (dopolnjevanje slike)

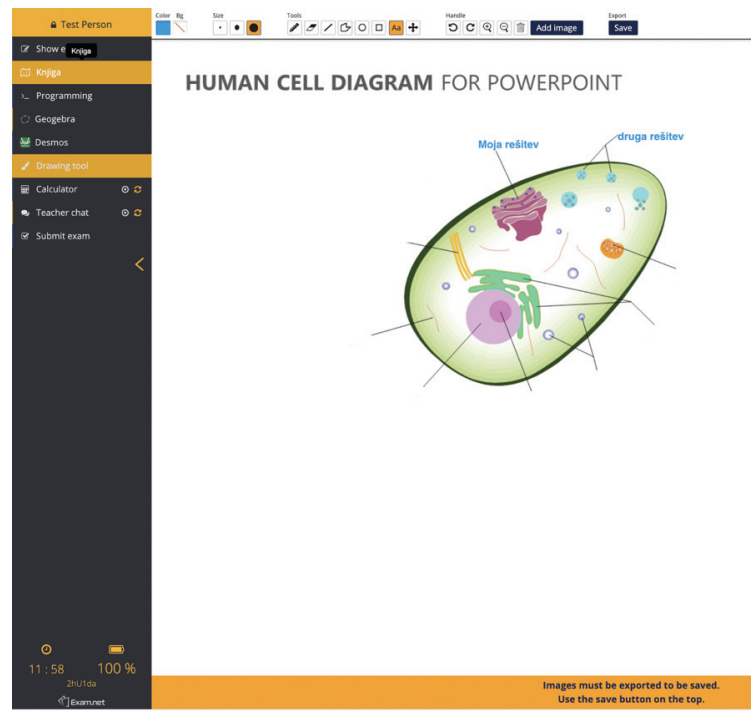



V javnosti je prevladovalo mnenje, da izobraževanje na daljavo ni enakovreden način izobraževanja in da študentje niso dobili znanja, ki bi ga v klasično izvedenem pedagoškem procesu. Avtorica monografije je do t. i. "prenosa" znanja s strani učitelja kritična, saj meni, da bi se moralo slovensko visoko šolstvo prilagoditi sodobnim paradigmam. Spremeniti bi se morala vloga učitelja in študentov, uveljaviti bi se moral k študentu usmerjen proces učenja, kjer znanje gradi študent, učitelj pa ga pri tem le vodi in usmerja. Svoje trditve avtorica podkrepi s primeri izvedbe predmetov s področja poslovne informatike. Evalvacije izvedbe predmetov temelijio na skrbno zbranih podatkih in kažejo, da lahko študentje, $\mathrm{z}$ osmišljenim in načrtovanim, procesno naravnanim, pedagoškim procesom, dosežejo boljše rezultate kot so jih dosegli študentje pretežno klasično izvedenih predmetov. Poseben izziv v času epidemije je predstavljalo izvajanje izpitov na daljavo, ki jih avtorica monografije predstavi $s$ teoretičnega in empiričnega vidika.

prof. dr. Janez Bešter

Pomemben prispevek monografije predstavljajo v njej predstavljeni primeri in dobre prakse študija na daljavo $v$ Sloveniji. V tem okviru avtorica prikaže odzive izbranih slovenskih visokošolskih zavodov na pandemske omejitve, s katerimi se je v preteklih dveh letih soočalo slovensko visoko šolstvo, ter rezultate nekaterih projektov uvajanja študija na daljavo, ki so poleg prepoznanih dobrih praks, pomembno prispevali tudi $\mathrm{k}$ diseminaciji in promociji načel uspešnega študija na daljavo tako med učitelji kot tudi študenti v Sloveniji. Ta vidik ustrezno zaokrožujejo poglavja, v katerih avtorica predstavi odnos ključnih deležnikov v slovenskem visokošolskem izobraževanju do uporabe informacijsko komunikacijske tehnologije, pa tudi obseg uporabe interneta ter različnih spletnih orodij med študentsko populacijo, kar Sloveniji omogoča relativno uspešno uvedbo študija na daljavo. Ugotovitve avtorica utemeljuje na rezultatih različnih raziskav, izvedenih $\mathrm{v}$ okviru univerzein $\mathrm{v}$ mednarodnem okolju.

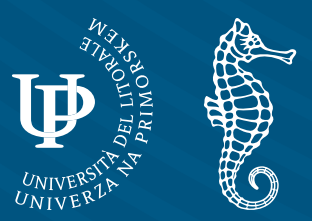

